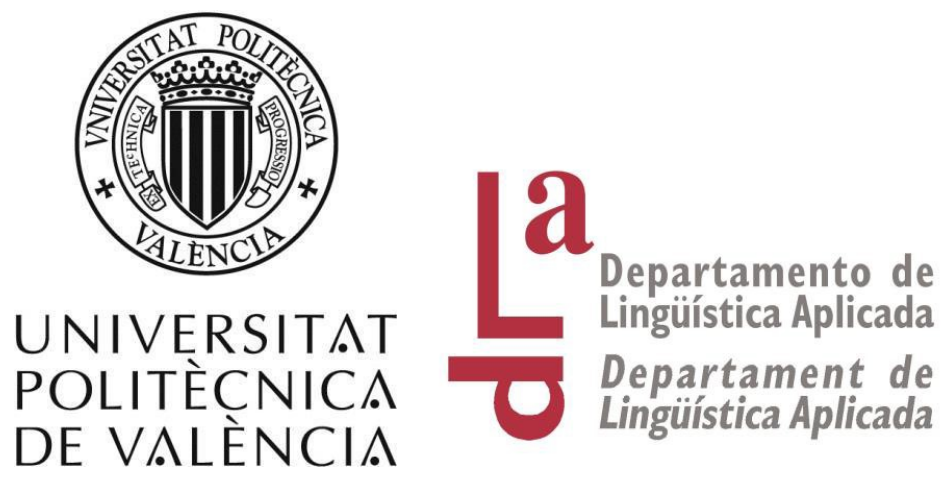

\title{
Application of Genre and the Harkness Pedagogy for the Advanced Development of Writing Skills in Spanish in Foreign Language Courses
}

\author{
Author: Paloma García Montés \\ Supervisor: Dr. Lina Lee
}

Valencia, June 2021 
In memory of my mother Manuela Montés Valls

To my children Carlos and Olivia

$-1-$ 
-2 - 


\section{ABSTRACT}

The gender instruction called the non-fiction personal narrative or memoirs, together with the Harkness method of teaching in the written expression of Spanish as a Foreign Language, will demonstrate in the particular context of an American University in Spain and in the US a higher development of this ability and performance. The author of this thesis would like to contribute to a long-awaited Spanish writing presence as L2 in the research literature. This study tries to develop in SFL classes for American university and students' new methods that manage to awaken the desire since there is no need in this context to learn Spanish. Based on the experience in teaching Spanish to American university and high school students, on the one hand, in the United States as a mandatory requirement by the university for credit in foreign languages and, on the other hand, in American academic programs of immersion in Spain (in both cases following the books and the method imposed by the universities) it is common for students and teachers to be dissatisfied. The intention is to demonstrate that with the Harkness pedagogy and the teaching of written expression through the personal essay genre, it is possible to create an academic curriculum where clear improvements are obtained in the final learning. Besides, it creates an environment where students are motivated and happy to learn a second language. The construction of gender and gender-based instruction could be carried out in a socio-contextual foreground to allow SFL students to see the content in terms of language from the beginning, rather than having to integrate them later. SFL's university study programs have at their disposal shaping their destiny, the quality of their program, and that of their students' learning. The objective will have been achieved if the 
study has convinced readers that SFL university programs can be revitalized by applying a humanistic, at the same time, language-based orientation. 


\section{RESUMEN}

La instrucción de género denominada narrativa personal de no ficción o memorias, junto con el método de enseñanza Harkness en la expresión escrita del español como lengua extranjera, demostrará en el contexto particular de una universidad americana en España y en Estados Unidos un desarrollo superior de esta habilidad y desempeño. A la autora de esta tesis le gustaría contribuir a una tan esperada presencia de la escritura del español como L2 en la literatura de investigación. Este estudio trata de desarrollar en las clases de ELE para estudiantes americanos nuevos métodos que logren despertar el deseo, ya que no existe en este contexto la necesidad, de aprender español. A partir de la experiencia en la enseñanza del español a estudiantes universitarios y de secundaria estadounidenses, por un lado, en Estados Unidos como requisito obligatorio por parte de la universidad para el crédito en lenguas extranjeras y, por otro lado, en programas académicos estadounidenses de inmersión en España (en ambos casos siguiendo los libros y el método impuesto por las universidades) es común que estudiantes y profesores estén insatisfechos. La intención es demostrar que con la pedagogía Harkness y la enseñanza de la expresión escrita a través del género ensayo personal, es posible crear un currículo académico donde se obtienen claras mejoras en el aprendizaje final. Además, crea un ambiente donde los estudiantes están motivados y felices de aprender un segundo idioma. Se podría llevar a cabo la construcción de género y de la pedagogía basada en el género en un primer plano socio-contextual, de manera que permitan a los alumnos de ELE ver el contenido en términos de lenguaje desde el principio, en lugar de tener que integrarlos más tarde. Los programas de estudios 
universitarios de ELE tienen a su disposición la configuración de su destino, la calidad de su programa y el de los aprendizajes de sus alumnos. El objetivo se habrá logrado si el estudio ha convencido a los lectores de que los programas universitarios de ELE pueden revitalizarse aplicando una orientación humanística, al mismo tiempo, basada en el lenguaje. 


\section{RESUM}

L'orientació cap al gènere denominat non-fiction de la narrativa personal o Memoirs juntament amb el mètode Harkness d'ensenyament en l'expressió escrita d'ELE, en el context particular d'una Universitat Americana a Espanya i als Estats Units, demostrarà un desenvolupament més elevat de aquesta habilitat i del seu rendiment. L'autora d'aquesta tesi desitjaria contribuir a una llargament esperada presència de l'escriptura de l'espanyol com a L2 en la literatura d'investigació. Aquest estudi tracta de desenvolupar en les classes d'ELE per a estudiants americans nous mètodes que aconsegueixin despertar el desig, ja que no existeix en aquest context la necessitat, d'aprendre espanyol. Basat en l'experiència en ensenyar a estudiants universitaris americans espanyol, d'una banda, als Estats Units com a requeriment obligatori per part de la universitat de crèdit en llengües estrangeres $\mathrm{i}$, de l'altra, en programes acadèmics americans d'immersió a Espanya (en els dos casos seguint els llibres i el mètode que imposen les universitats) és comú el desistiment i descontentament per part dels estudiants i professors. La intenció és demostrar que amb el mètode d'ensenyament Harkness juntament amb l'ensenyament de l'expressió escrita a través del gènere de l'assaig personal és possible crear un contingut acadèmic on no només s'obtenen clares millores de l'aprenentatge final, sinó que s'arriba a crear un ambient on els estudiants estan motivats i contents d'aprendre una segona llengua. Es podria dur a terme la construcció de gènere i de la pedagogia basada en el 
gènere en un primer pla soci-contextual, de manera que permetin als alumnes d'ELE veure el contingut en termes de llenguatge des del principi, en Iloc d'haver de integrar-los posteriorment. S'haurà obtingut l'objectiu si l'estudi obté lectors convençuts que es poden revitalitzar programes universitaris d'ELA mitjançant l'aplicació d'una orientació humanista, a el mateix temps, basada en el llenguatge. 


\section{INDEX}

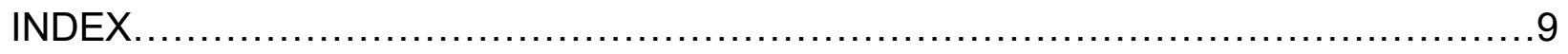

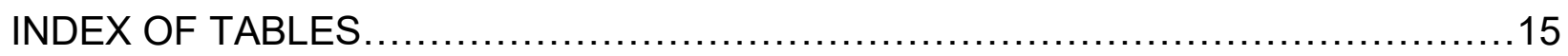

INDEX OF FIGURES AND WORKSHEETS ........................................17

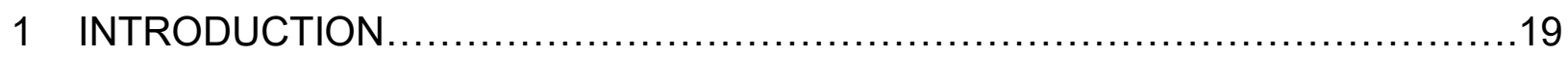

1.1 Thesis Primary, Secondary Objectives and Research Questions..................24

2 FOREIGN LANGUAGE STUDIES IN U.S. HIGHER EDUCATION ..................29

2.1 The Ideology of Nationalism and Language in the US .........................29

2.2 History of language teaching and learning in the U.S ............................. 32

2.3 Spanish Language Departments at American Universities.......................34

2.4 Current Situation: reuniting language and culture ............................... 36

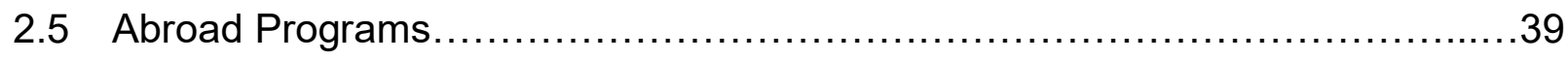

2.6 Research on Language Learning Abroad ...................................... 43

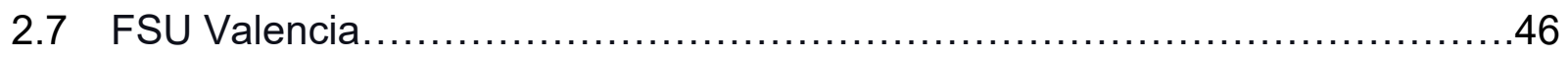

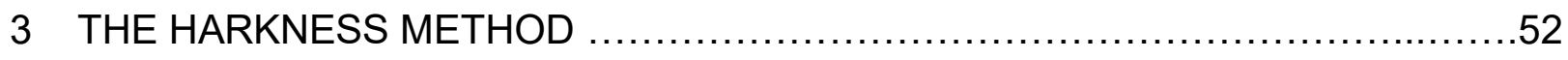

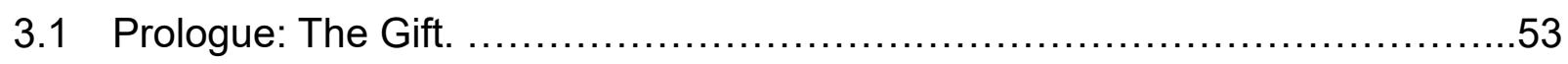

3.1.2 Other Harkness practicing schools. .....................................62

3.2 Teachers' experience on the ways of the Harkness classroom

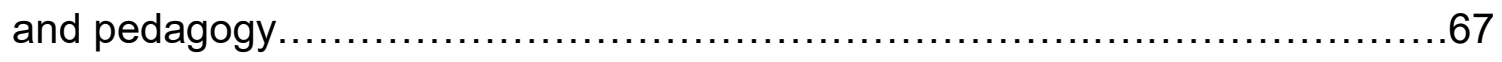

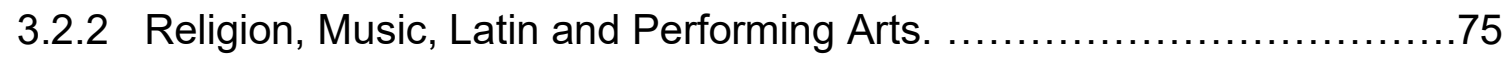

3.3 Role of writing in the Harkness class and in developing advanced foreign language literacy, writing exercise and model text. 
4 WRITING EMPHASIS .86

4.1 American and other research on second language writing development.........87

4.1.1 Writing progress: syntactic abilities and textual meaning-making ..........92

4.2 Systemic Functional Linguistics (SFL): a textual and functional interpretation of grammar.

4.2.1 Metafunctions and genres. .96

5 IMPLEMENTATIONS OF A GENRE-BASED INSTRUCTION OF FOREIGN LANGUAGE WRITING DEVELOPMENT 101

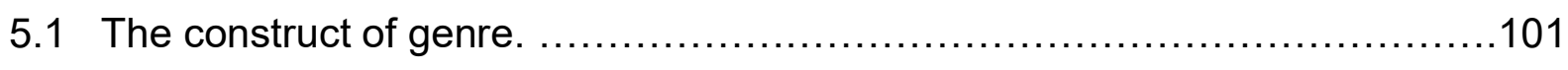

5.2 Foreign Language Writers Making Selections. ................................104

5.2.1 Example of a text progression with a series of historical genres. .......109

5.2.2 Illustration of a series of memoir genres from the Spanish Civil War....112

5.3 The personal essay genre, introduction, themes and forms...................122

5.4 Translating insights about the personal essay genre into genre-based writing tasks

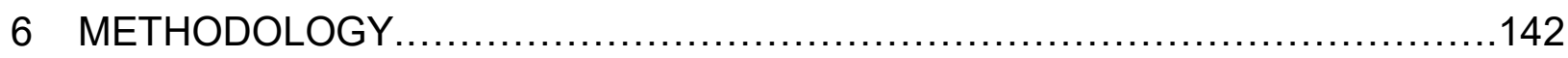

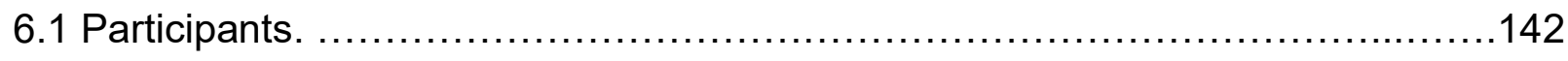

6.2 Description of curricular scope and sequence

Answering question 1.1 How students produce syntax within the writing tasks assigned

6.2.1 Field, Tenor, and Mode. 150

6.3 Generating an idealized writing profile for our level: discourse, sentence and lexicogrammatical characteristics expected Answering Question 1.2 How to monitor and negotiate curriculum and pedagogical actions through forms of assessment 153 
6.4 Writing Instruction: Rothery's and Harkness pedagogy

6.4.1 Principles of scaffolding and modeling 166

6.4.2 Harkness discussions as narrative in class and independent construction:

PE based writing tasks and drafts. 170

6.5 End of level writing task - Prototypical writing Task (PPT) for levels I and II Answering Question 1.2 How to monitor and negotiate curriculum and pedagogical actions through forms of assessment.

\section{APPENDIXES:}

Answering question 1.2 How to monitor and negotiate curriculum and pedagogical actions through forms of assessment

6A End-of-level Writing Performance Profile, Level II............................183

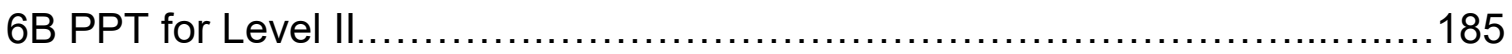

6C Example of a Student's Performance from Saint Anselm College............187

6D FSU 2016 Spring Roster with their authorization to publish and to work

with their compositions........................................................ 190

7 RESULTS

7.1 Results for Research Questions $2 \& 3$ - Assessment of foreign language student learning with the personal essay genre approach

7.2 Results for Research Question 1.3 - Design of assessment rubrics with level specific writing expectations

7.3 Data collection of meaningful writing exercises. 200

7.4 Results for Research Question 2 - Data coding methodology for extracting meaningful and reliable observations from the learners' PPT writing performances. .205 
7.5 Results for Research Question 2 - Data analysis report 210

7.6 Results for Research Question 2 - Comparative Study of Baseline Writing Task and Prototypical Performance writing task. 215

7.6.1 Results for Research Question 2 - Further comparisons of PPT from two different instruction routes (genre-instructed class vs. traditional instruction on same level) 221

8 CONCLUSIONS .227

8.1 Research Question 1: The specific focus, a worthwhile contribution 227

8.2.1 Research Question 1: Benefits of genre-based writing progress .229

8.2 Research Question 2. 231

8.3 Research Question 3: The Harkness method and its meaningful educational change in foreign language studies education 233

8.4 Conclusion. 239

9 ANNEXES 242

9.1 Different versions of the Harkness Table .242

9.2 Scoring rubrics for writing assessment .244

9.3 Writing prompts for Level II and Example performance of one student with major syntactic statistics related to his essays 246

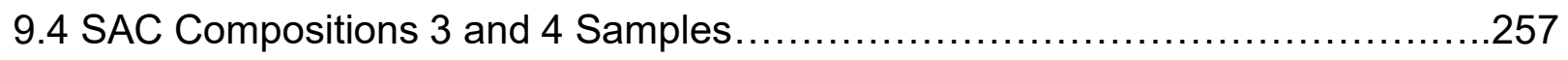

9.5 PEA Compositions Samples and Subordinate Clauses per T-Unit.................268

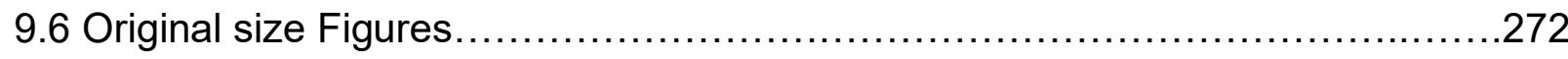

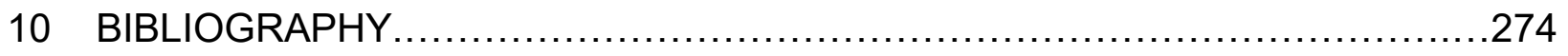


Acronyms Used

\section{ACTFL}

American Council on the Teaching of Foreign Languages

BWT

Baseline Writing Task

Cl

Confidence interval

CTU

Clauses per T-unit

EAP

English for academic purposes

EFL

English as a foreign language

ESL

English as a second language

ESP

English for specific purposes

FL

Foreign language

L1

First language, native language, mother tongue 


\section{L2}

Second language

MLA

Modern Language Association

MLC

Mean length of clause

MLTU

Mean length of T-unit

PPT

Prototypical performance writing task

SFL

Systemic Functional Linguistics

SLA

Second language acquisition

\section{SLW}

Second Language Writing 


\section{INDEX OF TABLES}

Table 1: Genres across the GUGD curriculum: from primary to

secondary discourses.................................................

Table 2: Genres in History ...................................................111

Table 3: SCW Timeline ..........................................................

Table 4: Genres Across the Spanish Civil War................................121

Table 5: Different "Types” of Creative Non-Fiction Writing .....................126

Table 6: Personal essays especially suited themes and prompts for FL teaching

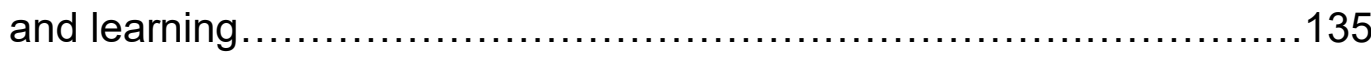

Table 7: PE Features, Themes and Forms ..................................137

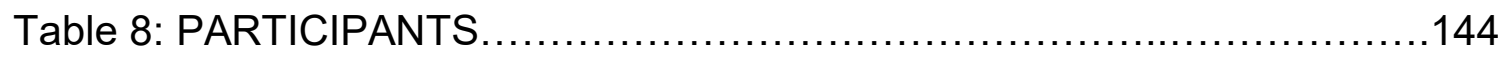

Table 9. Model Design of Literacy-Based French Curriculum....................148

Table 10: Initial Design of FSU Curriculum....................................149

Table 11: Generic Example of Personal Essays Progression in our

Curricular Level II..................................................152

Table 12: Study of the Personal Essay Genre Moves...........................161

Table 13: Sentence stems and Semi Fixed expressions for Scaffolding Learner's ability to give a recommendation and write a hypothesis in a level IV

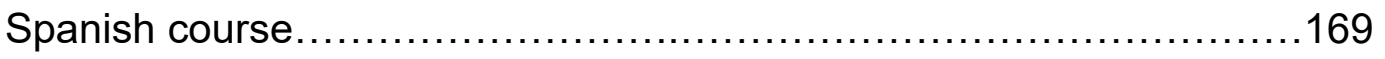

Table 14: Example of Different Students' Take on Same Task.................196

Table 15: Assumptions of SFL and Traditional Grammar.......................201

Table 16: Number of Data Samples by Level and Track.......................206

Table 17: Number of longitudinal Data Samples on the PPT ..................206 
Table 18: Number of Cross-Sectional Data Samples on the Prototypical Performance Task (PPT)

Table 19: (1) How do college-level American FL writers develop their genre awareness, linguistic knowledge, and writing competence in a systematically designed genre-based writing course that incorporates personal essays/nonfiction writing tasks? And 1.3 Do syntactic patterns match the expectations of the curriculum?

Levels I-IV: Course Design, Prototypical Performance, and Syntactic Complexity Development. 223

Table 20: (3) How proficient can students become when surrounded by best learning conditions, such as the Harkness method and small class numbers, when introducing genre-based writing tasks throughout the duration of a language course? And 3.1 Do learners in different educational settings with an SFL educational approach generate complex syntactic writing as well? Comparison of Syntactic Complexity Outcomes on the FSU PPT

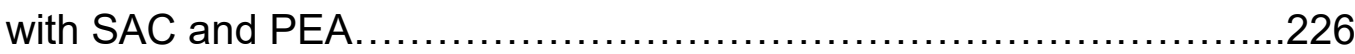




\section{INDEX OF FIGURES}

Figure 1: Spain is "different", Visit Spain ...........................................45

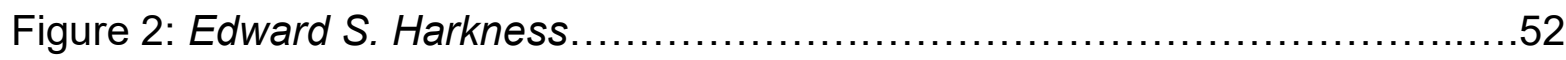

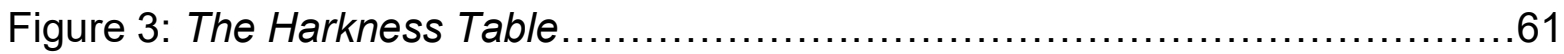

Figure 4: Harkness table and French Instructor....................................67

Figure 5: Wellington School, UK, Harkness sans table..........................242

Figure 6: At Lawrenceville School new tables can be divided too. ..................242

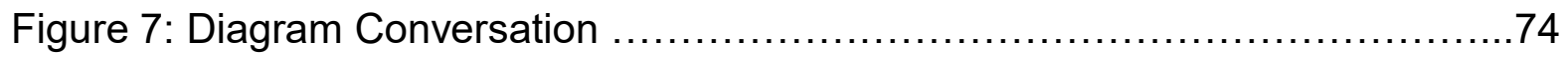

Figure 8: SFL by Halliday ........................................................

Figure 9: SFL Semiotics and Metafunctions ......................................96

Figure 10: Relations of Three Metafunctions .....................................97

Figure 11: Extralinguistic Features Motivating Linguistic Features....................98

Figure 12: Genre, Register and Language ........................................ 99

Figure 13: Halliday`s Language and Context, System and

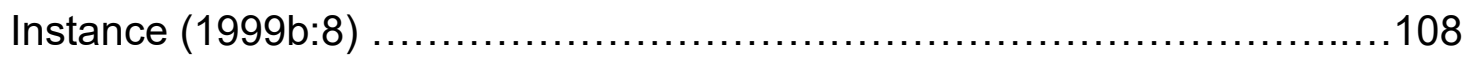

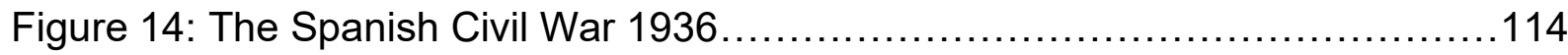

Figure 15: The New London Group (1996), Kern (2000) ..........................146

Figure 16: SFL Three Language Functions......................................151

Figure 17: The Teaching and Learning Cycle....................................159

Figure18: Joint Teacher and Students Writing Construction......................171

Figure 19: Students Qué/Cuál review uses at PEA 2019 Winter Term...............202

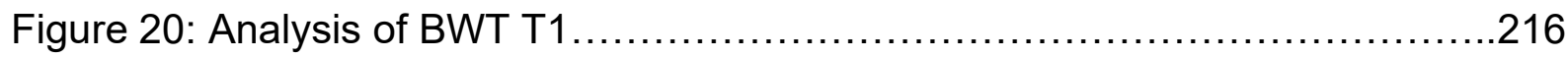

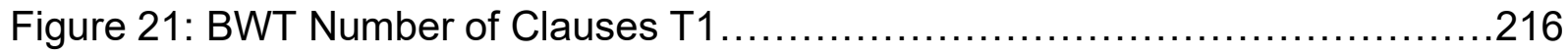


Figure 22: PPT Mean Length of T-Unit T1 ...................................... 217

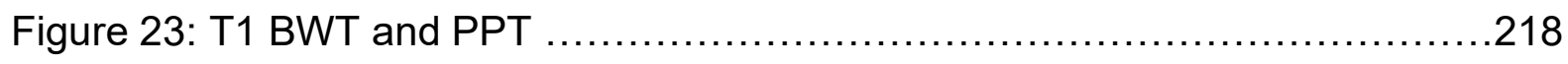

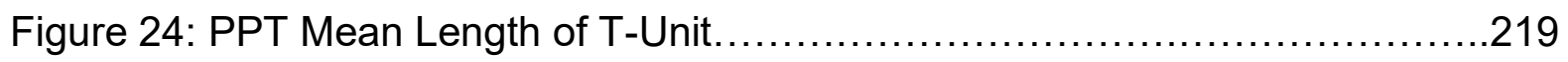

Figure 25: Confidence Interval of Both Tracks ...................................220

Figure 26: (2) How does college-level American FL writers' proficiency final acquisition compare to the same college-level American traditional L2 learners' knowledge?

Syntactic Development of T1 and T2 ................................221

Figure 27: Number and Type of Subordinate Clauses in T-Units

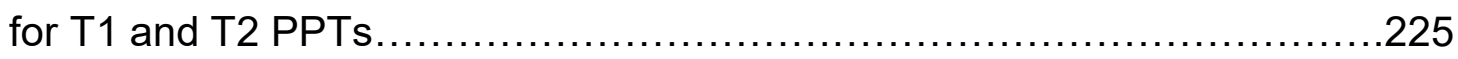

Figure 28: PEA, FSU and SAC PPTs Comparison............................. 231

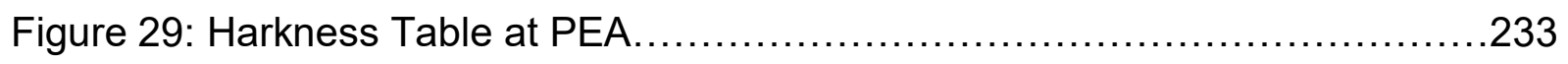

Figure 30: PEA students writing a summary of a story in my class..................234

Figure 31: A METIC example from my winter term .................................238

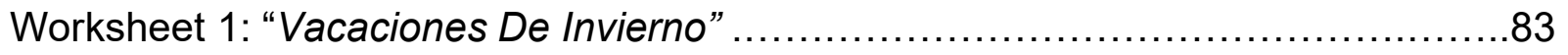

Worksheet 2: "Summers: Describe what you used to do during the summer when you

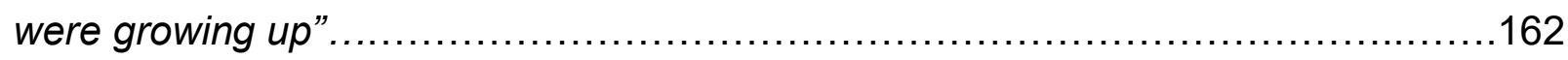

Worksheet 3: "Instrucciones para la composición \#1: Recomendaciones para un nuevo estudiante. /Recommendations for a new student. .178 


\section{INTRODUCTION}

This thesis presents a case study on writing development located within a U.S. collegiate study abroad program (Valencia, Spain), and addresses some of the educational objections confronting that particular context. It assumes that writing development is a valued indicator of Foreign Language (FL) high levels of abilities success, and paraphrasing what Slobin stated, the main objective was "to create thinking for writing" (Slobin, 1996:96). Besides, writing production has the advantage of easily identifiable and specific features for analysis and assessment.

With an approach of writing development during the Spring of 2016, I wrote and designed the curriculum, instruction, and assessment for a semester of Spanish Level II. The final results confirmed the premise that it improves the quality and extent of the learner's performance.

The perspective I offer introduces as well the realities in a study abroad context in Spain, and some of the issues that arise in the teaching and learning of Spanish, cultural assimilation, and the resulting student's immersion experience.

In her study about abroad programs Kinginger noted that "As American students navigate a globalized landscape dotted with Disney icons, Starbucks stores, and McDonald's corporate logos, to what extent are our students at risk of reading the world as a superficially exotic but basically familiar source of infotainment?" (Kinginger, 2009:224) She stated further that international educators dealing with these tendencies are even more convinced of the necessity of study abroad programs (Kinginger, 2008), I couldn't agree more. As Falk and Kanach observed, I have also experienced this American 
provincialism in some students' national self-sufficiency attitudes and, by extension, culturally impoverished. (Falk \& Kanach, 2000:167).

Nowadays, students have to actively choose what kind of immersion experience they want to have. My particular program setting has been defined many times as students' living in a bubble'. What it means is a parallel world as close as possible to an American collegiate environment. Students share apartments in buildings that also house the administration offices and classrooms. One difference is that they get their apartments cleaned up every day, so all they have to do is wake up, get some clothes on, eat breakfast, and come down to class. Many, at times, breakfast is on the run and spills into the classroom.

As you can imagine, the physical presence of fellow Americans and the conventional mobile devices for virtual interaction make any authentic or continuous relationship with the target culture very difficult. As someone that has had to learn another language in the target culture, living, studying, and successfully working in England and then the United States, I can attest to a different attitude and experience in order to be able to achieve that status. First, there was a need to learn the target language and a profound wish to achieve a proficiency high enough to access the working pool, if needed. I also possessed an admiration of the literature and cultural features that made me curious to know more. How to ignite that curiosity in these students that have their attention somehow directed away from their immediate reality? I certainly was determined as their language educator to do my best in developing a curriculum that would guide them back into the culture they were living in and into their interpretation and understanding of the link between language and culture. 
Like other student pursuits, learning a language occurs within a social, historical, and institutional context. Being outside their institution and country of origin brings its own variables: study-abroad participants may be included or excluded, welcomed or rejected, received with enthusiasm, or with indifference (Norton, 2000). Also, Kramsch ideas resonated on many occasions: "language learners are not just communicators and problem solvers, but whole persons with hearts, bodies, and minds, with memories, fantasies, loyalties, identities" (Kramsch, 2006a:251). These complex people had different life goals, different intentions for their language acquisition, and reacted differently to the receiving culture, but my purpose was to bring them all to the table throughout their personal essays and the Harkness method implemented in our classes. I sure hoped to take them away as far as possible from ethnocentric views and monolingualism.

What could I do as a language educator and Valencia native to improve the status quo? After many frustrating attempts within a collegiate abroad environment of trying to deliver an authentic context/cultural-related language Spanish education, I created a new approach, benefited from other successful case studies (Duff, 2008), that focus on advanced FL literacy development. Despite learning the target language while being immersed in foreign cultural content, FL students could not reach satisfactory levels of language abilities at the end of intensive semesters of Spanish instruction.

I want to underline that it will be very beneficial if universities established a requirement or desired language ability prior to a study-abroad semester. My case study was first and foremost made possible by the Valencia program adoption of a student's placement test for the first time. 
I initially defined my ideal outcomes of the course and then worked towards these goals by finding theories and responses for these expectations. One of the main objectives was to aim at developing language and content side by side throughout the semester and herein create materials and instruction for that purpose. The importance of self and learners' assessment for revising instruction and tasks towards improving and ultimately achieving more advanced L2 learning results was essential not only for this study but also for the curriculum.

As texts interpret knowledge and present relationships, the content must reflect both the nature of creating that understanding with probable language resources and writing tasks that provide opportunities to practice them. I chose to implement this approach with the help of the Personal Essay genre. So that by attaching students' learning to a text, they would, in time, accomplish a higher proportion of writing proficiency as proficiency in texts.

Mainly I wanted to follow through Matthiesen's challenge and "create a "cline of instantiation" that "extends from text instances to the overall systemic potential of a language-from the acts of meaning that make up a text to the meaning potential that makes up the linguistic system" (2006:41- 42, original emphases).

This is a formidable challenge, a particular text that links up with a language system that becomes part of the FL learner metalinguistic awareness, or insight into how texts come to mean, from the very beginning to the more competent final writing abilities. Future $L 2$ writers would have to make an effort to develop their meaning-making reserve and to be as formally accurate as possible at the same time. Thus, the need for a guided analysis 
of texts and the process of writing based on the paramount curriculum and compatible pedagogies.

The first part of the study introduces the history of FL education in the United States and the current situation. It also covers the setting of abroad programs, including our particular context in FSU Valencia.

Next is a description of the Harkness pedagogical method that I chose to implement in class and writing to develop advanced foreign language literacy. Although writing is an individual activity, the Harkness approach followed in the classroom gave abundant opportunities for forming classroom communities that support writing by way of various activities and tasks that coexisted with the actual writing exercise. For me, the Harkness method incorporates this move from synthetic to analytic syllabi, advocated by Long and Crookes (1993), where you analyze learners' needs first when thinking about curricular and task-based language teaching. It also helped bring out students' differences with ease and integrate them into their personal essays and in the classes learning experience. Somehow, I wanted their overseas experience to act as an equalizer among them and my class as the patio ${ }^{1}$, where you learn and share everything.

The following chapter focuses on second language writing and explains the construct of genre to outline stages throughout the curriculum to achieve the intended advanced learning results. On the one hand, Systemic Functional Linguistics (SFL) theory is introduced as a textual and functional interpretation of grammar. On the other, the construct of genre and a genre-based pedagogy might be explained as making contextual

\footnotetext{
${ }^{1}$ Schoolyard
} 
features prominent so that learners would be aware of content as a language from the start, instead of learning about it after that.

This genre idea is then translated into writing tasks that followed a proposed curriculum path and instructional concepts. What to teach and in what order is introduced with the help of the Personal Essay genre.

\subsection{Thesis Primary, Secondary Objectives and Research Questions}

The primary research objectives of this thesis are:

A. To find a genre-based theory to form a predominantly text path for L2 learning and apply it to the Personal Essay genre family.

B. To implement and develop a genre-based pedagogy for writing development that systematically engages language and content at this level.

C. To formulate level-specific learning results and to develop end-of-level writing tasks.

D. To evaluate the language abilities achieved.

The secondary research objectives of this thesis are:

- To find out how students produce syntax within the writing tasks assigned and to learn if syntactic patterns match the expectations of the curriculum.

- To define how to monitor and negotiate curriculum and pedagogical actions through forms of assessment. 
- To discover if learners who complete the same curricular level via different instructional pedagogy produce writing with similar syntactic complexity and if learners in different educational settings with an SFL educational approach generate complex syntactic writing as well.

On this basis I formulated the following three research questions:

(1) How do college-level American FL writers develop their genre awareness, linguistic knowledge, and writing competence in a systematically designed genre-based writing course that incorporates personal essays/non-fiction writing tasks?

1.1 How do students produce syntax within the writing tasks assigned.

1.2 How to monitor and negotiate curriculum and pedagogical actions through forms of assessment.

1.3 Do syntactic patterns match the expectations of the curriculum?

(2) How does college-level American FL writers' proficiency final acquisition compare to the same college-level American traditional L2 learners' knowledge?

2.1 Do learners who complete the same curricular level via different instructional pedagogy produce writing with similar syntactic complexity?

(3) How proficient can students become when surrounded by best learning conditions, such as the Harkness method and small class numbers, when introducing genre-based writing tasks throughout the duration of a language course?

3.1 Do learners in different educational settings with an SFL educational approach generate complex syntactic writing as well? 
To this end the methodology chapter was planned to define the concepts and Prototypical Performance Writing Tasks used to gather data to reach conclusions which would corroborate or refute the thesis research questions.

The assessment of learning findings, included from the very beginning, is at the center of chapter seven. This perspective toward assessment is very different from the traditional approaches such as formative and summative assessment which make student learning results as the final stage. Measures had to be established in order to be able to assess the soundness of the statements, confirming or correcting if needed, that I had integrated into the curriculum for the advancement of writing development, so that "Assessment can show that connection, particularly when it is approached with self-critical self-awareness and when it occurs within a curricular context" (Byrnes, 2002b:436). The assessment also reports extensively how the curriculum supports the emergence of FL writing abilities by taking syntactic development as a vital marker of the advanced targeted literacy. Syntactic development is realized in the curriculum, not only in terms of lexicogrammatical structures. Instead, tasks are modeled around the ability to write essays that correlate the context's intention, which in turn provides other relationships of reality, such as analysis, comparison and difference, categorization, and chronological order. The difference between these and the traditional composition tasks is that they are based on a genre deliberately adapted and designed for our level to obtain the best learners' writing performance.

From my humble point of view this study approach has the advantages of its traceability for monitoring not only within this particular class but can be applied in others too; its creation of a learning experience that incorporates meaning through texts that integrate 
language and content; its connection between L1 and L2 abilities and reading and speaking; its inherent reflective and attentive quality of the writing process; its emphasis on creating a safe community through the Harkness philosophy to promote individual learning within a strong class group; its opportunity for frequent personal teacher's feedback; its formation of individual critical thinking through the genre of the personal narrative.

Even though this study is located at an abroad program in Spain for a specific study level, the insights gained can be applied to other levels and FL settings. FL studies abroad present remarkable opportunities for faculty and the entire department to create an innovative language-based Spanish program, taught with a humanistic perspective and culturally connected, which could finally leave behind a linguistically conceived curriculum.

However, study abroad in itself will not provide students with available insights such as a better appreciation of global diversity and international human solidarity. American students need to cultivate empathy and respect for others before embarking in a semester abroad and an awareness of language learning as a long-term investment of time and effort. Whereas some students will always regard study abroad as an impasse from their real studies, others are eager to be part of a cosmopolitan and multilingual world.

As language educators in Spain, we should actively seek to emphasize a more successful language competence at all levels, which will have a far and lasting effect in Spanish departments and reject the folklore and inadequate international education that surrounds most American study abroad programs. 
The study ends with an analysis of the questions and lessons learned from investigating the content, instruction, assessment, and outcome of the semester systematically, and suggests that it is indeed possible to create a successful Spanish curriculum for the generation of advanced writing abilities within an abroad collegiate FL program. 


\section{FOREIGN LANGUAGE STUDIES IN U.S. HIGHER EDUCATION}

The United States is a homogeneous English-speaking nation. Traditionally citizens of this country have projected an image of themselves as a mainly Christian English nation where immigrants from many parts of the world become assimilated. As Ricento (1998) argued, the general American policy reflects "deep values" within a society that has considered preserving the culture and language of origin as not socially or economically valuable. Given the absolute value of English that most Americans possess, the study (or teaching) of any other "inferior" language carries a few contradictory ideas, and competency of any foreign language is incredibly low (Tucker,1991).

\subsection{The Ideology of Nationalism and Language in the US}

Philips (1998) reasoned that some nationalist ideologies centered around monolingualism could play, especially in institutional environments, an essential role in transmitting the kinds of dispositions that will result in the abandonment of the original instruments of expression or modes of speech by the dominated (Bourdieu 1995). For Valdes et al. (2003), in nations with multiple languages, these dispositions support the national language and reject the acquisition of nonofficial and minority languages.

In American culture, to finally master the English language, "the crowning attribute of citizenship" (Jordan 1921:35), is a stepping stone towards achieving the American dream. Any other language has little or no space in American society, and Spanish, in particular,

is often associated (negatively) with problematic illegal minorities that demand 
government services in a non-English language (Valdes, 2003). However, the case of Puerto Ricans is different since they require these services but are legal citizens. My experience as a court interpreter for many years in the Trial Court of M.A. can attest to that perception.

Nevertheless, as Valdes remarks, it is also true that "the term bilingual in the United States is often used as a euphemism for poor, new immigrant children who are "monolingual speakers of their immigrant language." (2003:5)

Here in Europe is a diametrically opposite story; a second language's acquisition and proficiency are viewed as the economic and social ultimate success. I have my family's example, which was not the general norm but represented a hard-working elite in my hometown of Valencia. My father and uncles went to German Shule from kindergarten. My grandfather thought that acquiring a second language and music (another kind of communication) was a gift to his children (I have very carefully done the same with mine). In Europe, the German, French, Italian, British or American schools were and are an institutional representation and promotion of their country's culture. I guess we think that "extranjero" (foreign) is useful and better for many people. Of course, I am not saying that a pure nationalistic and thus external rejection sentiment and those in between, does not exist. Still, it is safe to say that, at least in Spain, all educated or striven to be population consider the mastering of a second or third language as a highly valuable skill. Nowadays here in Valencia (pop.1,705,702 to 2,516,818), there are eleven English bilingual schools, The French Lycée and Deutsche Schule Valencia. 
Again, for anybody anywhere, second language acquisition is a long process that requires the advancement of four skills: listening, speaking, reading, and writing. The textbooks that universities offer for teaching try to encompass all of them with little success. The situations they portrait for speaking are cartoon-like, or they heard them many times before ("Voy a la biblioteca por la mañana" - "Tomorrow I am going to the library"), so far all the big commercial textbooks that have been imposed to teachers and students alike, are equally removed from the business of learning a second language. From my experience, you will find more precious drops of knowledge from dedicated teachers who have imagination and are happy to share it.

When I worked as a Spanish teacher for a bilingual (nursery to high school) French school in Boston, I also found that their literate/focus approach was different from their English counterparts. Since the students were used to writing their own stories, whether in journals or as part of the coursework, the textbooks contained much more relatable and imaginative stories to work with.

On the other hand, in the U.S., only a minimum of students achieves a useful level in the languages they study. Some reasons for this state of affairs lay in the small-time devoted to F.L. study (Lambert 1985), commercial pressures to use textbooks and methods from big publishing companies, the lack of quality training for language teachers and effective pedagogies, and as I mentioned before a negative attitude towards bilingualism also plays a part (Schiffman, 1996). In my opinion, training language teachers in the Harkness method, a writing focus teaching, and genre-based pedagogy will make excellent strides towards a higher proficiency level. 


\subsection{History of language teaching and learning in the U.S. within foreign cultural and language departments}

The Coleman Report of 1929 advocated a reading orientation in language learning; later on, the Army Specialist Training Program during World War II recommended an oral approach. To Bernhardt the effects of these historical, political, and social circumstances were instrumental for the teaching and learning of reading and writing for the remainder of the 20th century:

This thirty-year foreshadowed the language teaching schizophrenia with which the profession ends the century: the tension between the traditional, humanities-based, reading-oriented study of belles lettres and views advocating functionality and oral proficiency; the paradoxical image of language as part of the humanities but simultaneously in the service of government and the military; the social problems of maintaining and valuing a cultural identity while encouraging people to assume another; and the economics of promising in a short term what can only be delivered in the long term.(Bernhardt,1998:51)

Canale and Swain's article "Theoretical Bases of Communicative Approaches to Second Language Teaching and Testing" and Omaggio Hadley's Teaching Language in Context (1986) supported the subsequent movement towards communicative proficiency concentration for university F.L. education in the United States for the next three decades. Indeed, an essential change from memorizing words or reciting the rules of grammar. The ACTFL Proficiency Guidelines $(1986,2001)$ and the Standards for Foreign Language Learning recognized that "students should be given ample opportunities to explore, develop, and use communication strategies, learning strategies, critical thinking skills, and skills in technology, as well as the appropriate elements of the language system and culture" (Standards, 1996). 
Although the aims correlated with students' wishes to learn a second language, the reality was very different. Language instruction at university is short, and the lower levels, which have the highest numbers of students due to mandatory enrollment, are supported by commercial textbooks and programs that favor oral and audiolingual learning. Consequently, the educational gain credited to everyday communicative competence has been officially established, too, because studies of language majors show high ratings according to ACTFL guidelines.

I could not agree more with Schulz (2006) when he claimed that any quality of oral mastery is not natural to accomplish but: "communicative competence is neither a realistic nor a sufficient goal for a general education F.L. requirement...the reality is ...conversational activities that have an undeniable tourist quality and essentially turn the teacher into an observer of a classroom scene filled with role-plays and group and pair work." (p.254)

According to Kramsch, what is missing is "the manipulation of symbolic systems...the focus on semiotic choice, and the ability to interpret meanings from discourse features" (2006:251). Swaffar observed that the discarded post-World War II audiolingual predilection and the communicative approach were comparable as they have in common a "primary learning objective that would apply in everyday verbal exchange" and the language capacities taught "were relatively isolated from social and historical contexts and posed few opportunities for learners to think about and analyze multiple sources of information about the social, political, economic, and cultural characteristics of F.L. speakers." (Swaffar, 2006:246-249) 
Many language instructors before me have found these results frustrating. I also made my goal following Swaffar suggestions to devise a new approach to language instruction:

Communicative competence could take on an entirely new meaning if the ability to read, write, listen, reflect, and communicate intelligently about a culture's multiple facets were to become the chief goal of F.L. programs at all levels, from beginners to graduate students. (Swaffar, 2006:246-249)

\subsection{Spanish language departments at American universities.}

European languages taught in primary and high schools in the U.S. are given the noncore curricular status (despite the No Child Behind Legislation, which designated them as a core academic subject), and are not adequate development of advanced skills. Therefore, institutions of higher education worldwide inherit the responsibility to set them in motion.

In America, academic departments of international studies teach primary literature. Language teaching at elementary levels is made a requirement for students to graduate, Spanish being the most popular choice. Right now, language instruction becomes a business for multinational publishing companies (and some faculty staff) and when nontenure-track faculty try to deliver this all-included Spanish curriculum. The long-term or temporary contract instructors and other unpredicted faculty bear solely the burden of trying to teach and develop valuable F.L. expertise within the elementary and mandatory level of study.

As Alice Kaplan (2009) recounted in her memoirs, language teaching becomes the essential purgatory that can finally lead to a dream job, in her case at Duke University, 
where she could teach twentieth-century literature to undergraduate and graduate students, and where she finally got tenure (Loc.1582).

In reality, it is only majors and minors and graduate students who are in touch with the faculty in most language departments and Spanish is not different. They are then divided into literature and art and less prestigious language and SLA sections. There are more women than twenty years ago in literature positions, but it remains the fact that language instruction, especially at the lower levels, is regarded with disdain, even though it makes their own teaching possible (Kaplan, Loc 1713).

Furthermore, at the very center of this setup is the inability to deliver the corresponding learning outcomes that define the core educational goals, enabling students to acquire considerable F.L. cultural knowledge and language abilities across different contexts, which is advanced L2 literacy.

The results of this imposed textbook driven language instruction are courses that ignore content for the first four semesters of study followed by courses with content specified primarily by faculty that ignore the language and pursue or not, the undercurrent cultural mission of the general program (if any).

When asked about teaching and learning Spanish, faculty members that express an interest in the subject recommended extended residency in Spanish-speaking countries as the best solution to the problem of developing any proficiency (Valdes, 2003). It is easy to understand based on my own experience and for many of my generation's instructors because we learned by becoming 'immersed' in the target culture. This is the 'sink or swim' immersion that unfortunately few students nowadays experienced. 
Nevertheless, going back to Spanish departments, it seems as if the lack of progress is sent abroad like a boomerang only to come back, shamefully the same. Blaming the native teachers in the place of sojourn is unproductive because they are constrained by the textbooks supplied from the U.S., by the setting itself that mirrors the American college experience where students even share an apartment, and especially by the whole organization of their stay as a touristy tour, where absolutely everything is taking care. There is no room for self-exploration or much independent learning.

Indirectly by overprotecting American students abroad

...departments transmit ideologies of nationalism (one language, one nation), standardness (a commitment to linguistic purity and correctness), and monolingualism and bilingualism (assumptions about the superiority of monolingual native speakers) (Valdes, 2003:24.)

The conclusion I derived from my experience is that the majority of Spanish departments are unable to guarantee their students the advanced levels of literacy that are much in demand in today's globalized society and that contemplating a writing orientation could integrate speaking, listening, reading and cultural content, the very educational goal usually refers to, for the improvement of F.L. studies.

\subsection{Current Situation: reuniting language and culture}

D. James (1997) made a distinction between "forum leaders" or literacy-cultural studies talented professors who were indifferent to the language base of their academic study and "workshop leaders," as those professionals bearing in mind competent FL teaching throughout students' undergraduate education (p.4). 
The MLA, dedicated to literary-cultural theoretical studies, suggested in a 2007 report that "the FL major should produce educated speakers who have deep translingual and transcultural competence" and the capability of operating between languages (p.237) and yet gives little support to the language aspect base of their scholarship as if graduates reach the necessary almost-native competence by supernatural powers or during abroad programs (!).

In addition, these goals are not consistent with The American Council on the Teaching of Foreign Languages (ACTFL) guidelines, which puts greater emphasis and is focused on developing speaking abilities in assessment, textbooks, teacher education instruction and certification (leaving aside reading or writing), as the essential quality to gain in FL learning.

The ambitious and worthy proposals that language should be studied "in cultural, historical, geographic, and cross-cultural frames within the context of humanistic learning" to be able to understand "and analyze the cultural narratives that appear in every kind of expressive form from essays, fiction, poetry, drama, journalism, humor, advertising, political rhetoric, and legal documents to performance, visual forms, and music" in the MLA report (p.238) are not supported by any measures or recommendations as to how to acquire such high levels of FL expertise.

The literature scholar Berman pointed out, "there is, therefore, a considerable gap between the language blindness of cultural studies as an intellectual movement and the embrace of culture by the foreign language community" (2002:6). The study of FL texts within a given genre includes both a cultural-literary and a language focus. How can this approach be better instructed to the language student? 
Systemic Functional Linguistics (SFL), a theory of language developed by Halliday, is influenced by the anthropologist Malinowski's (1935: cf. pp 4, 18, 58) concepts of "contexts of culture or situation" reflected in a language form. His theory understands the context in linguistic terms, "taking account of the differing situational contexts for different levels and kinds of teaching/learning activities" (p.1). Furthermore, learning semiotic/interpretative or symbolic abilities in an FL should be the intended goal as topics are explained and in this way learning "the FL as a system of making meanings with the aid of a pedagogy that foregrounds language as a social semiotic (Byrnes, 2006a, 2006b). The language itself becomes the substance and the instrument of learning subjects, content, styles, registers, and finally, grammar. In this approach, language is both text and cultural context.

Academics like Swaffar made "The Case for Foreign Languages as a Discipline" presenting other languages "as systems that do things with words aesthetically, culturally, linguistically, and socially" that could be incorporated into all levels of instruction (1999:8). Wellmon, on the other hand, proposed an even more radical cultural studies with a linguistic emphasis defined by "constant attention to the particularities of how languages function and mean with respect to particular cultures" (Swaffar, 2008:295).

If language systems convey culture, they can also provide topics or contents in different genres, offering different learning opportunities. As Bazerman and Prior specified, "These questions focus on what texts do and how texts mean rather than what texts mean" (2004:3). So that any language, oral and written, comes to mean what it does in its sociocultural context and, in turn, what it means to learners. I found that the Personal Essay Genre was instrumental in starting students, "highlighting the language-based 
nature of knowing, learning." Certainly not by asserting general communicative goals or learning the grammar of their native language through an FL's, or by studying literary texts individually.

To develop the "desired mental skills which are entirely dependent on the mastery of the linguistic patterns in which these skills are realized and construct that 'knowledge' in varying patterns of discourse" (Christie, 1989:153) is the main objective of my dissertation by studying curriculum content, instruction and assessment of Spanish as a Second Language Writing (SLW).

\subsection{Abroad programs}

In 2005 the Abraham Lincoln Study Abroad Fellowship Commission indicated that participation in study abroad is the next major step in the evolution of American higher education (p.), similar to the establishment of the land-grant university system under the Morrill Acts of 1862 and 1890 and the Servicemen's Readjustment Act, or GI Bill of Rights of 1944 .

The Commission's report stated that "study abroad is one of the major means of producing foreign language speakers and enhancing foreign language learning" (p. vi).

As asserted by the Institute for International Education in their "Open Doors" report (2007) in the last ten years, the number of Americans studying abroad has grown by $150 \%$. In the academic year of 2005-2006, 223,534 U.S. students went abroad on academic programs. On the other hand, foreign language majors in their Junior year is no longer the typical arrangement for study abroad. More often, American students stay for a 
semester or less, and programs are geared towards offering courses for majors in the social sciences, business, or management studies.

The Institute for International Education corroborates this fact: from 1985 to 2003, the percentage of students spending an entire academic year abroad dropped from $17.7 \%$ to $7.8 \%$. In the same period (1985-2003), the number of business majors going abroad rose from $10.9 \%$ to $17.6 \%$, and the number of foreign language majors going abroad dropped from $16.7 \%$ to $8.5 \%(2004)$. Therefore, language learning is not a priority in academic programs abroad anymore, and the length of time that a given student spends has been significantly reduced.

Instead, FL departments and language educators in particular rightly see an in-country immersion as a reward for years of hard study and connect what you have learned with the live target culture. Since the language opportunities are there, students are expected to return with improved language abilities. Of course, academic professionals cannot help to transfer their own successful experiences abroad. In general, the experience as far as learning the target language is viewed as superior to classroom learning. Such is the trust in study abroad that in 2000 one American university abolished its foreign language department and instead sent language students to regular abroad stays (Schneider,2001).

If you compare American and European residences abroad, programs for language learning the different approaches are very clear. American programs since the 1950s involved students with little language proficiency and experience in living abroad who stay for short periods in sheltered environments. 
As Coleman explained, study programs:

Generally, envisage the short-term transfer of cohesive groups of American students to a different geographical base, where they may benefit from formal (classroom) and informal (naturalistic) language learning but without necessarily abandoning an American educational framework and academic/administrative support" (Coleman, 1997:1).

It is also regarded as a coming-of-age experience in other stances, as in Levin's ethnographic study (2001) of four female learners in the south of France.

This particular program did not put much weight on language learning but emphasized the once in a lifetime opportunity for maturity insight.

Another study in 1999 focused on training students in ethnography to aid them in acquiring a better perception of the target culture (Talburt and Stewart). During the fiveweek course in Spain, the main objective was to help students "to engage with and reflect critically on Spanish culture" (p.164). Unfortunately, it was not very successful because some of the students' negative interactions with Spaniards dominated the researchers' attention. Some of the pitfalls of these studies' nature and the reason that they do not yield many qualitative literature insights are that students often "by definition, do not necessarily understand the local meanings of events and interactions" (Kinginger, 2007). Therefore, it is safe to say that the American model of study abroad has a strong element of coming-of-age transition, which is heavily supervised, and as I observed in FSU Valencia, the student's association to the university is promoted as in the campus of origin with plenty of guidance and support as a group.

On the other hand, European students acquired more experience abroad and thus "matured in situations in which multilingualism is part of their natural habitat" (Murphy Lejeune, 2002). 
European study abroad programs include a more self-sufficient student who lives in another country for a longer time, and it is involved in the local, social, and academic institutions.

The ERASMUS program (European Community Action Scheme for the Mobility of University Students) encourages student abroad sojourns "as an instrument of European construction" (Murphy-Lejeune, 2002:1). In 2007 the ERASMUS program celebrated its 20th anniversary. It now counts with $90 \%$ of European universities and involves more than 150,0000 students and teachers every year. Students first apply to the program they are interested in, and once the home institution approves, they receive a grant for the university fees and a small stipend.

For American students, the short time spent abroad in similar academic settings as their home universities (studying majors considered a better investment than any in the arts curriculum) where they do not necessarily need the host language such as in preprofessional courses of study (Gore, 2005), might be a sound financial strategy for the survival and development of abroad programs. However, it does not contribute at all towards the development of language proficiency. Moreover, the number of students seeking and investing their time and money in language learning abroad has steadily decreased in favor of business majors.

As noted by Coleman (1997), in contrast to European programs, an American study abroad is characterized by its insular qualities, with only a minority of participants that seek any integration into the host society. 
The aforementioned study-abroad features (e.g., length, location, or curricular instruction), together with students' different identities, personalities, and individual desires, indicate that despite academic guidelines from language departments and specific policies from national educational institutions, the organization and goals of these programs do not often support the development of any language skills. In view of these circumstances, dedicated American students who aspire to acquire a high level of language competency are not catered for and would need to find different ways to pursue it in study-abroad settings.

\subsection{Research on Language Learning Abroad}

Since the publication in 1967 of Carroll's report about a national project assessing the proficiency among college seniors majoring in foreign languages, study abroad has been viewed as the ideal context for language acquisition. In this study, 2,784 language seniors were tested, and data on participation in study abroad included. For Carroll:

Time spent abroad is clearly one of the most potent variables we have found, and this is not surprising, for reasons that need not be elaborated. Certainly, our results provide a strong justification for a "year abroad" as one of the experiences to be recommended for the language majors. Even a tour abroad, or a summer school course abroad, is useful, apparently, in improving the student's skill." (Carroll, 1967:137)

Later on, more specific studies with separate elements of language proficiency have been published. The outcomes they reveal are not generally positive.

One of the reasons, according to Huebner, is that "the overseas experience seems to result in a much wider variety of performances and behaviors among students than does study at home" (Huebner, 1995:191). 
Researchers have changed the focus on language learning abroad to try to analyze specific students' activities together with performance evaluations. Interestingly De Keyser's study found that when comparing home and study-abroad students of Spanish, in tasks that involved grammatical features and communication tools in interviews and description of pictures, there was no difference in their language development and both groups showed a lack of knowledge in the use of the subjunctive, conditional, and relative clauses. They used the Spanish form ser and estar in similar ways when speaking (1991). When Collentine (2004) examined gains in grammatical and lexical abilities further, in both at-home and study-abroad groups, with the help of corpus linguistic tools, it revealed that study abroad groups had advanced narrative skills and increased the general semantics in the texts they wrote. In later studies, he concluded that while traditional examined lexical and grammatical forms from student tests, were slow to develop in study-abroad programs, other forms such as narrative competence, vocabulary knowledge, and awareness on the way language are used, and society's effect on it, were improved (2006, Lafford \& Collentine, p.104).

In Wilkinson's study (2002) for intermediate- or beginning-level French students in their first-time study-abroad, "speaking French" meant practicing the conversation patterns learned at their home communicative classroom. He found that this learned instruction's influence was considerable with conversations with most natives, but that the roles and norms they followed were incongruous in real exchanges in French (p.168).

The ideal view of study abroad is that it gives students the chance to use and connect language learning with their own experience. They can observe the ways people do or say things differently (remember the government slogan for Spain in the 1960s? Spain is 
"Different," Visit Spain), they could potentially have conversations with new friends, defend their opinions, and manage everyday activities like the natives they see. In any given situation, they will encounter a connection between language and culture, and inevitably some misunderstandings will occur, which will also deliver "rich points" or origins of insight and development (Agar,1994).

Figure 1
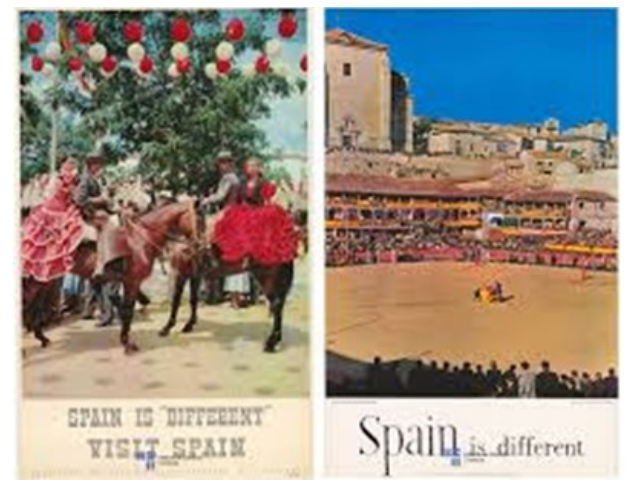

From my own experience, I agree with the line of thought that considers language learning and its development, once in touch with the target cultural diversity, as a new way to perceive and to talk about reality (Lantolf). Finally, it is worth mentioning that there are also important aspects of studying abroad to consider, such as students' characters and their interlocutors, obviously influenced by aspects of identity such as race, gender, and nationality (Block, 2007a, 2007b). 


\subsection{FSU Valencia}

According to Gore (2005), historically, study abroad is a feminized educational experience; it is also true for FSU Valencia. He noted that over the last half-century, between two thirds and three-fourths of the participants have been female: "study abroad programs are perceived as attracting wealthy women to academically weak European programs established in a frivolous Grand Tour tradition" (p. 24). At this time and age, I am not sure if you could link The Grand Tour tradition, inherited from the education of British gentry more than a century ago, to justify study abroad with leisure and general cultural enrichment rather than to serious learning. It will ultimately be the study abroad directors' responsibility to implement the general policy and mission for their programs. If they choose to emphasize the touristy and light academic demands to attract more students, it is their choice.

Associating the dominance of women in study abroad with lack of academic discipline and purpose, even if Gore connected the presence of this attitude to the history of women's struggle to be admitted to programs of professional studies, or assuming that collegiate education of genuine quality is only available in the United States, or that liberal arts curriculum is a waste of time and does not contribute to the advance of quality education abroad. Instead, it is better to acknowledge that a minority of participants exist in a study abroad program that is willing to study long and hard to enjoy an authentic immersion experience and want to achieve the necessary language skills to add to their success in future careers. 
Especially since the events of September 11 in 2001, a new student motivation has been introduced "describing international education as a means to contribute to world peace and security" (Gore, p. 136). This discourse has also been picked up, at least in theory, by program sponsors who believe that study abroad education would make students "become effective citizens able to contribute to the nation's development and the world's peace efforts, having enhanced their own international knowledge" (p. 136).

At this point, it is vital to introduce the influence of some of the various conditions that are provided to abroad students. For instance, the homestay setting is often believed to contribute to a more significant development of language competence, especially for short-term programs where there is less time to make local contacts or for those who do not have the option of sharing an apartment with their fellow students. In the FSU program, the homestay option was abandoned to eliminate any culture clash derived problems in favor of shared apartments with other American participants. A few students from other universities that attended the program had the homestay setting organized by an outside agency and seemed to love the whole experience.

Concurring with demographic statistics FSU abroad program typically entails short-term stays by students who are majoring in business or social science. For a study abroad to function as a program for language learning, on the one hand, the administrators must guide and support students towards this goal in an enduring way, on the other students have to hold a deep commitment to acquire a multinational element for her future career together with sincere curiosity and admiration for the traditions of the target culture. 
For FSU Valencia, language learning was not a high priority within the program or educational policy. However, it is also true that most students before they leave the US have the intention, as per their application for study-abroad, to speak Spanish and integrate with the target culture, but once they get there, are ill-equipped to deal with the pressures of cultural and language adaptation and seek the familiar company of American counterparts in order to create a life as close as possible to their home campus, except that now they visit as many European sites as a travel group or with friends as they can fit in. The whole experience is reduced to a trip of entertainment (Engle \& Engle, 1999:42). Some good practices from other immersion programs which could improve FSU or other programs with similar abroad policies:

The Portsmouth University's Residence Abroad Project from the United Kingdom is an example of how to optimize the experience of study-abroad students, by including a set of learning goals that extend to all aspects of their residence abroad academic, cultural, linguistic, personal, and professional areas. First, they prepare students before departure by reflecting on personal goals agreed and by a debriefing stage where student returnees are involved with their peers, and finally with strategies for maintaining all gains achieved (Coleman, 2005).

This approach will hold students accountable, and the interaction of returned students would make them reflect as to what is realistic to be gained. It would also help institutions in providing the resources needed at both their home and abroad programs. In the case of this project by PU in France, most students assumed that the language would be 
brought to them automatically just by being there. By the end of their study, they learned that it would take a lot of work and time.

I personally always start my courses with a tutorial about the essential features of language learning. It would help students and instructors alike if they were provided with an orientation class on this matter before their departure. In this way, their expectations could be closer to reality, and the understanding of the work involved recognized.

(e.g., Maximizing Study Abroad by Paige, Cohen, Kappler, Chi, \& Lassegard, 2002; and research evaluating the effectiveness of these materials in Paige, Cohen, \& Shively, 2004).

For instance, Engle \& Engle (1999) described a labor-intensive program organized with the intention of best-integrating students into the host community. It has proven to be quite successful. Students meet for a weekly conversation exchange with a local student, and they also volunteer for community service for at least 2 hours per week. Besides, it is made mandatory to participate in a "personal interest component," which is really to practice a hobby in the local setting.

Unlike FSU, where there is a week of organized travel every 20 days, this program does not provide any form of organized group travel. Students became so engaged in the community that even when they participate in any social gatherings from the program, they have to bring one local guest. As they get more involved with their abroad lives, there is less weekend travel, increased language ability, and admiration of local culture.

There are other programs as well that offer activities in the community at a smaller scale with some service component (Kiely \& Nielson, 2003), a video production project (Goulah, 
2007), opportunities to seek individual interests in local groups, sports teams or clubs, internships and tasks involving interviews (Archangeli, 1999; Raschio, 2001).

In broad terms, the results of these pedagogical and programmatic proposals are very encouraging, as they raise levels of reflection, create connections with the local community, and stimulate positive attitudes toward language learning. Students who do become engaged in local networks through such measures have benefited dramatically in their language acquisition by comparison to those who do not (Fraser, 2002). Even initiatives such as the telecollaborative classroom have demonstrated (e.g., Belz \& Thorne, 2006; Kinginger, 2004c), that participants become online friends while they study together. What would be the repercussions if academic collaborations online could be developed with peers in the target abroad community prior to their sojourn?

Another approach is the training in ethnography for language learners in a "mix of learning to communicate appropriately and developing an analytic understanding of another group's system of meanings" (Roberts, Byram, Barro, Jordan, \& Street, 2001:11). With this strategy, learners are trained in methods of observation, analysis, and writing, participating in the observation of "otherness," while they are aware that their own cultural interpretations influence their perspective.

According to Agar (1994), students begin to grasp language learning's nature to be aware of the complex relationship between language and culture (as languaculture:60). This approach, albeit ambitious, has been proven as documented in the work of the Ealing Ethnography Project in the United Kingdom (Roberts et al., 2001), in the development of ethnographic pedagogy for short-term stays abroad in the English Department of the 
Chinese University of Hong Kong (Jackson, 2006), and the work of American educators such as Jurasek, Lamson, and O'Maley (1995), among others.

Once abroad, some of these programs further involve students in ethnographic projects during their stay. Although not an actual academic ethnographic research, they indeed became more interested in the host culture and its people, and any prejudice could potentially be eliminated if not in every student, at least in exchange for observation and the subsequent reflection. American language learners abroad would be well served by efforts to encourage an analytic rather than a judgmental approach to the societies where they study. This is an overall better base for connecting linguistic forms and culture for the development of language competence. 
3 THE HARKNESS METHOD

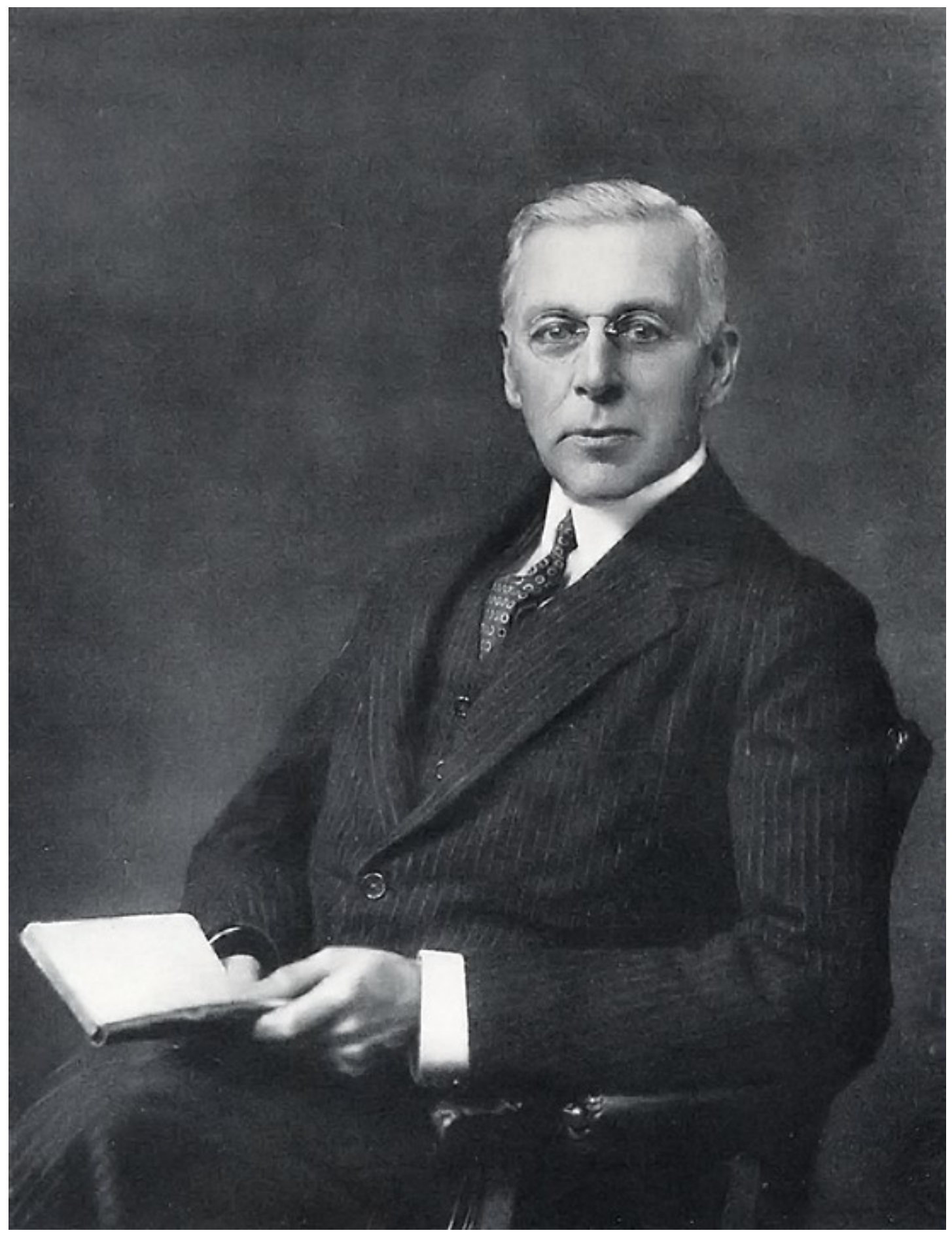

Figure 2: Edward S. Harkness 


\subsection{Prologue: The Gift}

In the 1920s, Edward S. Harkness, the last heir of one of John D Rockefeller's Standard Oil Company's original partners, had in his name one of the largest fortunes in America. He planned to redistribute his wealth "back to the people of the country from whose natural resources it came." From then until he died in 1940 he contributed 1.332 separate donations of amounts of $\$ 5.000$ or more, adding up to more than $\$ 129$ million to medical, educational, and cultural institutions in the United States and England: St. Paul's School, Exeter, Andover, Taft, St. Andrews University, Yale, Harvard, the Columbia P. Medical Center in NY, Wellesley College, to name a few (Heskel, 2008:1). He was also the founder of The Pilgrim Trust and The Commonwealth Fund and personally distributed his fortune while looking forward to the effects it caused during his lifetime.

He admired the British university system, especially the renowned Oxford and Cambridge colleges, and after that, he modeled from them his "House Plan" at Harvard, facilitating the college to rearrange around residential communities. In addition, the University of Oxford undergraduate tutorial approach is among the earliest illustration of bottom-up rather than top-down learning. (Hassan, 2015:208).

It was to England too that he sent his friend Lewis Perry, the then principal of Phillips Exeter Academy, to "see what you can find out," as he was interested in making some meaningful secondary education changes. He himself had been unenthusiastic about his whole school experience at St. Paul's and later at Yale. 
In January 1930, Perry visited 70 schools in the UK (Winchester, Harrow, Eton, St. Paul's, Westminster and more) and these were some characteristics that impressed him:

- The house system at boarding schools, with a housemaster or tutor acting as an adviser to each boy.

- Students in sections of similar ability.

- New methods of instruction in science and mathematics.

- Boys in the sixth form do advance work.

- Courses of study tailored to the individual student (Heskel:3).

When he suggested applying to PEA some of these concepts in the form of a tutorial program to support individual students, an honors program for the most capable students, a program of visiting instructors, smaller class sizes, and new faculty, Harkness replied that he had anticipated a more significant change:

You are thinking of improving an existing institution...I am thinking of something more radical...; something that is revolutionary in Secondary school education...I want to see somebody try teaching, not by recitation in a formal recitation room where the teacher is on a platform raised above the pupils and there is a class of 20 or more boys who recite lessons. I am thinking of a boy who isn't a bright boy, not necessarily a dull boy, but diffident, and not being equal to the bright boys doesn't get much out of the class, and has nobody to sit down with him. What I have in mind is teaching boys in sections of perhaps $8 . .$, not a formal recitation room (the importance of the setting)... where 8 boys could sit around a table with a teacher who would talk with them and instruct them by a sort of tutorial, or conference method, where the average, or below the average, boy, would feel encouraged to speak up, present his difficulties, and the teacher would know and realize what his difficulties were. This would be a real revolution in methods. (my emphasis).

(Heskel, 2008:4). 
A new plan (the Harkness plan) was resubmitted with originally these features and goals in mind:

- Exeter Academy would shrink the size of average classes from 25 to 10.

- Classes would contain boys of similar ability and would proceed at the pace best suited for them.

- New sections meant more teachers who would also provide a house system.

- An improved science program.

- All instruction will be carried on by the "Conference or Tutorial Method of Instruction" (Heskel, 2008:5).

In the proposal, Perry also included a conference type-classroom with books and pictures related to the subject matter, where students would sit around a table with a teacher who will not only have complete knowledge of his subject but who will also be able to lead discussions in a non-judgmental manner, sympathy and would ultimately instruct each boy "to learn to talk and to think while he is talking." (Heskel, 2008:5)

This time the committee's proposal satisfied Harkness, who gave the largest donation to any secondary school: $\$ 5.84$ million, or $\$ 83$ million in today's money, to implement it (Heskel, 2008:6).

Many new buildings with classrooms and dormitories were built. Also, the money went to faculty salaries, board, sabbaticals, building keeping, and more, but all the while, Harkness refused to have anything named after him. It is to his honor that his name is now associated to the very thing he cared most: the revolutionary and most progressive 
teaching and learning method of any high school in the United States: to be a Harkness teacher in a Harkness table, to produce a Harkness class by "doing Harkness."

Since PEA implemented this teaching and learning method in 1931, many other schools have replicated the system, as he expected. He also donated up to a quarter of a million to Phillips Academy Andover, Lawrenceville School, The Taft School, St. Paul's, Deerfield Academy, and The Hill School. (Hassan, 2015:37)

In the summer of 1936, Lawrenceville School, acknowledging the advantages of an active and collaborative kind of learning, redefined their classrooms around conference tables that sparked shared discovery and discussion, instead of the traditional lecture and memorization method (The Lawrenceville, 2015:4).

These principles have influenced PEA to change and adapt over the years. At the very beginning, they started right in the classroom: "the old Exeter custom of snapping the fingers. If the boy hesitates in his recitation, a fusillade of snaps from those who know or think that they know rings out." (Heskel, 2008:77) did certainly not help the needs of many students.

Likewise, the new faculty had to be different and the right kind of personality: "he must know thoroughly his subject and the art of teaching; and -what would naturally follow- he must command the respect and confidence of his colleagues and students." (Heskel:78) Because of the Depression, PEA was able to choose the best teachers from a pool of highly qualified unemployed workforce, and as it happens nowadays, many chose to stay until retirement.

As far as applying the new Harkness method, it came about gradually because there were no set rules to follow in class. The faculty understandably believed "that the whole plan 
would have to be experimental and subject to experimental verification...for we could not bind ourselves in advance to a certain fixed number in all sections in all subjects in all years." (Heskel, 2008:80)

Nevertheless, all classes started with three common elements: a small number of students sitting around a conference oval table, which would permit them to see each other's faces and to be on eye-level with their teachers, and lastly, sections arranged according to learners' abilities. In this way, students would develop within their tempo in the best learning conditions laid out for conference instruction and discussion.

As Henry S. Couse found during his first term of Harkness teaching, being above on a platform while teaching made him too far removed and "tended to hedge him about with too much dignity. Now, there is a freedom of discussion, an eagerness to participate, that I never saw before, the value of which to both student and instructor is incalculable. And it comes mostly from sitting around a table." (Heskel, 2008:80)

The seminar manner of educating was found to work best, distinguished historian Arthur M Schlesinger jr., a former student from '31, traced the main reason why when he reminisced:

We sat around tables and talked back to the master; education became, not a performance, but a process (my emphasis). Also, the standards were high...I had never worked so hard in my life. When I went to Harvard later, everything was easy. So far as the training of the mind was concerned, Exeter could hardly have been more effective for me. (Heskel, 2008:81)

As learning became the essential goal in class, grades rose, and as it had occurred in conference style small classes in England beforehand, writing became prominent among other skills as teachers had more time to look at students' papers. Vrooman, an instructor in English from 1937 to 1978 , really explained the most effective way to generate any learners' writing: "The way to teach writing, I soon discovered, was to cause the students 
to write...look at their work carefully...a weekly theme...a somewhat more ambitious paper every other week, but write at least once a week in class 15 to 20 mi." (Heskel, 2008:81) As this became the norm in the English Department, another teacher, Niebling, recalled that he would come into class and say "Assume the Angle," referring to the slides that you could pull out on the Harkness table, and felt that to have them answer in writing would immediately make them more organized and that it was a very important discipline. (Heskel, 2008:81)

In the mid-80s, "Fast" sections became "intensive," formerly "slow" sections were eliminated, and some subjects were divided into standard and intensive. (Heskel:82) Regarding the content curriculum, another exciting development in the 1950s came about when the History Department started to use different materials and primary sources instead of the single textbook, "so students could evaluate both the evidence and modern interpretations of it" (Heskel, 2008:83). I personally found the use of only primary sources to be far more interesting when I wrote my master's dissertation about the Spanish Civil War. Much later in the 1990's the Mathematics Department also chose problem sets over textbooks. Taking this direction showed how much the teachers cared about their subject's content and their students as people of intellect.

Perhaps the Academy has not provided a specific pedagogy for their teachers because there is no one way "to do Harkness." Depending on their year of study, students might need more or less guidance from their instructors. In experienced classes, they tend to discuss with each other at a quick pace the topic presented. However, the Harkness class will fail if students do not come prepared or if the teacher cannot advance the discussion 
by bringing into it some of the student's observations, or if the class combination of personalities is not right to establish good communication.

Still, students will learn to interact with teachers and students and "to ask questions, two crucial skills, regardless of discipline." (Heskel, 2008:85). With Harkness, you teach students the skills needed to become their own and each other's teachers.

The Harkness Plan also influenced the content to be taught. There were doubts about whether the school should teach skills or content, what required or optional courses students take, and if it was better to expose students to a variety of fields or instead to specialize in a few with greater understanding (Heskel, 2008:86)

One of the first classic studies to be questioned and eliminated was the traditional Latin requirement. Although recognized to give a strong basis for learning romance languages, discipline, grammar, logic and expression, other "live" and more functional languages were sought after the war. Again, mirroring some schools in England, all significant departments by the 1940s started to offer "a college-level course to its top students, anticipating by several years the development of the Advanced Placement Program elsewhere" in America. (Heskel, 2008:93)

Another significant change regarding content occurred during the eighties. At the time Harvard University had adopted a "core curriculum" which intended to aid students to think and write successfully, "understand methods for gaining knowledge, be informed about other cultures and other times, gain insight into moral and ethical problems, and attain some depth in a field of knowledge." To achieve these, students would have to take courses in the required areas of literature and the arts, history, social and philosophical 
analysis, science and mathematics, and foreign languages and cultures; there would also be a compulsory component in expository writing. (Heskel, 2008:97)

PEA also adopted a plan to address its students' diversity, and the increasing number of institutions outside the long-established Ivy League. Very similar to the back to basics Harvard proposition, it focused greatly on skills:

We believe our graduates should be able to read, write, speak, and listen effectively...They should be able to apply mathematical and experimental methods of analysis, to identify and understand historical problems, to ask ethical questions, and to comprehend languages and cultures other than their own. (Heskel, 2008:98).

At this time, faculty committees were created for content development, scheduling, and academic advising so the faculty would be able to see the student as part of the whole Academy and not just within a subject (Heskel, 2008:100). A straightforward decision was made regarding the classrooms' best size by calculating the room needed to accommodate a Harkness table (Heskel, 2008:106).

As far as students' admission, the Deed of Gift was clear that Exeter would recruit "youth of requisite qualifications from every quarter" (Caplan). In the late sixties, about one-fourth of Exeter students were on scholarship, and the Academy was meritocratic in academics, sports, the arts, and is overall organization. Social class was eliminated from the school. Presently approximately half the students (51 percent male, 49 percent female) are white, about a quarter Asian, about a 10th black, fewer Hispanic, with the rest unknown (Caplan, 2016, 9, 6th). PEA has almost 1,100 students, 529 of them receiving financial aid (82 percent or more with a grant of 80 percent of tuition), and a $\$ 1.2$ billion funding. Furthermore, there is no difference between graduation rates from students who received scholarships and those whose families paid for their education (Caplan,2016, 9, 6th). 
Since a year's tuition and mandatory fees for a boarding student are $\$ 48,550$ and only about $5 \%$ of American families can afford them, the school decided in 2007 that any admitted student from a family with a household income of $\$ 75,000$ or less, would receive a full scholarship. The Academy also supplemented the amount of scholarship money for students whose families made more than 75,000 but did not have enough for full tuition and fees. Significantly, the school also noted that "it seems unlikely that the country's smartest and most motivated students actually reside in the gene pool of the upper $5 \%$." (Caplan, 2016, 9, 6th).

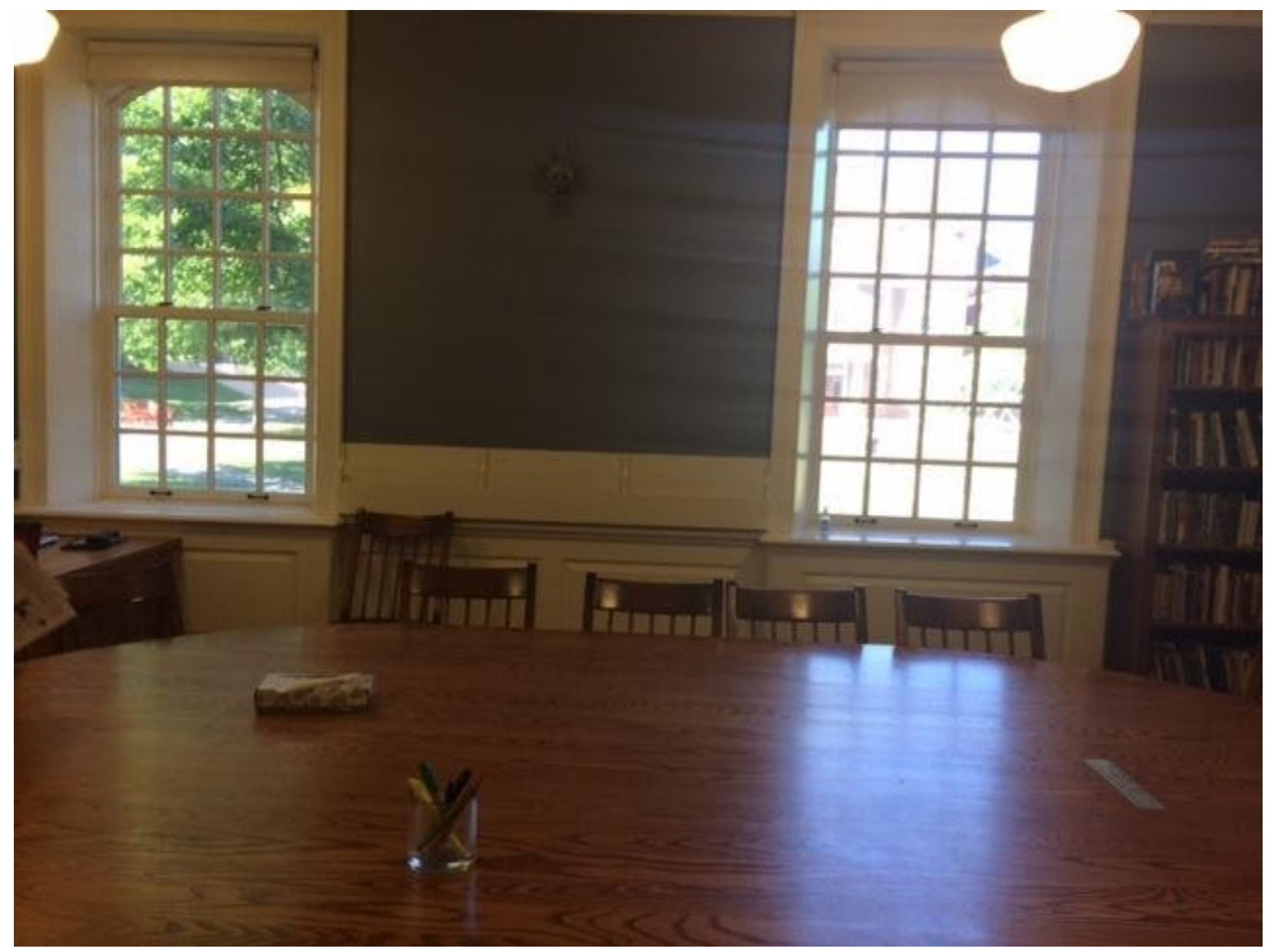

Figure3: The Harkness Table 


\subsubsection{Other Harkness practicing schools}

For Lawrenceville School, following the Harkness method of learning and teaching, whether in science labs or smart boards, means supporting students "to learn and think for themselves, then to subject preliminary understandings to critical review. An assignment or class isn't just something to get through; it is something to get into, an opportunity to make things happen. How? Take an interest. Take responsibility. Take part." (The Lawrenceville, 2015:4).

In a traditional setting, the teacher will provide her/his selection of information or follow an assigned text, and students would expect a deliverance of this content and an evaluation once they memorize it and repeat it in tests. Furthermore, that is how it has been for many years, and the majority of educational institutions worldwide. The Harkness method requests students to take the lead in classroom discussions, with the teacher as a moderator, not the fount of knowledge. (The Lawrenceville, 2015:16).

In a Harkness class, instructors know their subjects beyond mere information and focus on the different ways and exercises they can create to learn for themselves: "students of students" (The Lawrenceville, 2015:5). It is not an easy task and takes years of accumulated Harkness experience to master it. One must be prepared to give guidance at the right time to continue to develop their knowledge best, individually, and as a group. (The Lawrenceville, 2015:5- Pier Kooistra P'19). 
Dr. Seung Kim, a well-known stem-cell researcher at Stanford University, and Exeter student, was in front of the entire student body of Lawrenceville School when he began his lecture by saying:

I won't be talking about stem-cell research today, in fact, I won't be talking about myself at all. I want to talk to you about my high-school science teacher and the reason I became a scientist. His name was Mr. Brinckerhoff. He taught us the importance of asking questions, questions that don't yet have answers. (The Lawrenceville, 2015:6).

He recalled that in 1976, Mr. Brinckerhoff published an article in Nature magazine on his research on Stonehenge and how he had spent a great deal of time wondering how the 20-ton lintels atop the uprights had gotten up there. They later saw a picture of him in the article "on his hands and knees crawling about on top of Stonehenge, his nose a few inches from the stone surface." He found a series of pits arranged at regular intervals that coincide with the rising of the moon over an 18-year cycle. "It was all about asking the right question," said Dr. Kim, "and this was Mr. Brinckerhoff's gift as a teacher as well." (The Lawrenceville, 2015:8).

His fundamental point was that scientific research is a sum of observation, listening and asking the right questions: "High-school science curriculum will remain utterly boring if we continue to make students plow through labs that already have answers," he concluded. (The Lawrenceville, 2015:8).

The Harkness table presence and design are important, but Mr. Brinckerhoff's method of teaching showed students to observe before speaking, to listen "first so that an answer builds on the previous comment; and in that process, the questions that occur to us will be our own questions. 
And this can happen almost anywhere - in a classroom, on top of Stonehenge, or on a walk in the woods. (Stephen S. Murray H'55 '65 P'16, Head Master, The Lawrenceville, 2015:8).

Naturally, at Noble Academy, "diversity means teaching students how to get along with the country's white majority." (Caplan, 2016, 9, 6th). The Academy situated in Chicago follows the Harkness method of learning too. They believe that the more students develop their minds, the smarter they will turn out. The oval might be made of rectangular tables, and a semicircular one at each end, but is where notwithstanding the good work of learning happens.

In the Chicago public school system considered the worst in the Reagan administration country, only 14 percent of ninth-graders will graduate from a four-year college. In the Noble Network of Charter Schools, they are set to change the odds. To start with, students must show respect and pay attention. Besides, charter schools are responsible for its performance but by the same token can hire teachers according to more flexible standards, and their content and method of instruction are also adaptable.

Since public school teachers Michael and Tonya Milkie founded the first Noble Charter School in 1999, Chicago now has 130 charter schools. "Ninety-seven percent of the network's graduates get accepted at four-year colleges", the majority on scholarships, and "84 percent are the first in their families to go." (Caplan, 2016, 9, $6^{\text {th }}$ ). As a result of this progression in 2015, the Noble Network won a "national prize as the highestperforming group of charter schools in the country serving a large percentage of poor and minority students." (Caplan, 2016, 9, 6th). 
Pablo Sierra started the Noble Academy in 2014; of the 400 students, 75 percent or more will graduate from a four-year college, even though 83 percent are from poor or lowincome families, and 96 percent are minorities. Many choose to go there, even if they have to travel an hour or more on any public transport combination, and the school is obliged to accept them. (Caplan, 2016, 9, 6th).

Noble's Academy collaboration with Phillips Exeter's has been crucial for this success. Having recruited two Noble students for PEA summer school in 2008, Sierra sent some faculty from his network to Exeter to visit. He was looking for ways to avoid "the Noble Alumni Death Spiral" at the time: 90 percent started out at a four-year college, but only 75 percent returned after the first year, and fewer than 40 percent graduated (Caplan). He thought that he could change it with the Harkness method: "I wanted to give my kids what Exeter kids get." (Caplan, 2016, 9, 6th)

Reading scores at lower levels and sections of honor students increased dramatically after they were instructed with Harkness. To counteract the larger class size at the lower level, students would read first for half an hour, and then they would be divided into three seminar groups with the teacher rotating among them. "Something that is revolutionary in Secondary Education, as Edward Harkness imagined" (Caplan, 2016, 9, 6th), could influence the whole of Chicago public schools.

The story of Aida Conroy, a student from Exeter on a full scholarship, and now in her second-year teaching at Noble, illustrates their working relationship. While it took some time for her to feel confident around the table, she notes that she felt "unusually committed after the first year," and at the end of her studies, "Important. Like I was expected to do something important with my life." (Caplan, 2016, 9, $6^{\text {th }}$ ). As a PEA student, experiencing 
Harkness for her meant "to believe that there is more than one person at the table you can learn from, and then, that you have the ability to teach someone, too." (Caplan, 2016, 9,6 th).

Before she started to teach, the Noble school sent her to a five-day workshop of Harkness training at Exeter. There she met Rebecca Moore and instructor in the course and in Conroy's words, the best teacher she is ever had. She became member of the English department, a Harvard graduate of education with more than 20 years of teaching experience. In 1999, she and three other teachers created the Exeter Humanities Institute, and the workshop was established. So far, teachers from 223 schools have attended, from New England to Bangkok. The Institute was established to teach Harkness skills and peculiarities from teachers and students.

For example proven strategies such as the use of "name cards in the early days of a class to make easier for students to credit each other's ideas, or having students prepare questions about their reading to discuss in class raises the chances that they will get involved in the discussion; assigning a student to take notes on a discussion and present them at the next class is likely to improve that student's listening; and encouraging students around the table to change chairs from class to class raises the chances that they will stay agile in shifting roles in discussions-from questioner to summarizer, for example, or from derailer to connector." (Caplan, 2016, 9, 6th). 


\subsection{Teachers' experience on the ways of the Harkness classroom and pedagogy}

We must enter each class with an enthusiastic commitment to the usefulness of that hour, with a concern for our students, and a love of what we teach." (Cole, 1981:21).

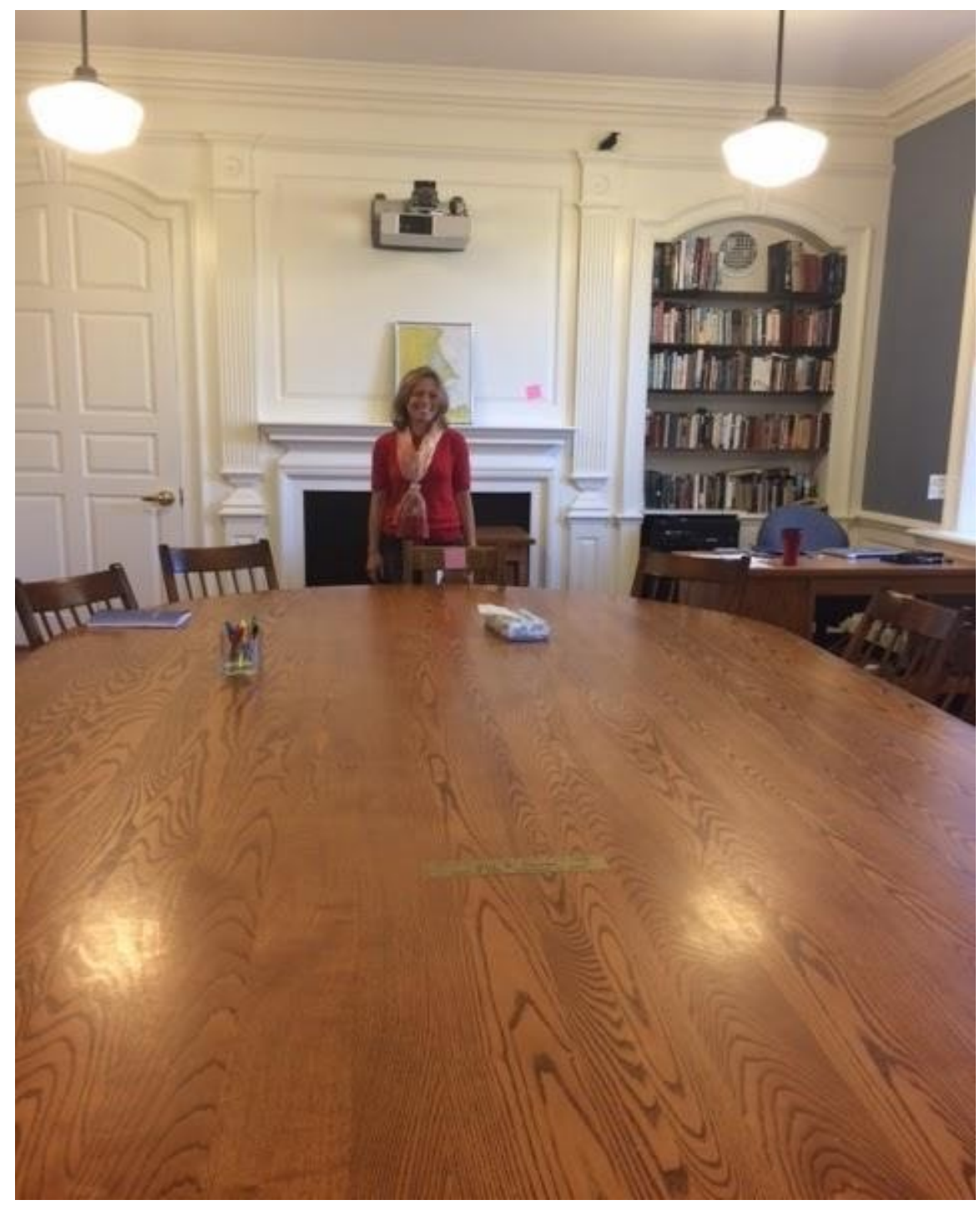

Figure 4: Harkness table and French Instructor.

It seems as if I have not been the first person to wonder and ask if there is a book that will guide me on how to be a Harkness teacher. According to Thomas E. Hassan (14th principal of Phillips Exeter Academy), the reply has always been "No". 
There is no one way "to do Harkness," no tried-and-true formula that, if followed, will produce a successful Harkness class.

I agree with Mr. Hassan the systems to teach and learn around oval Harkness tables could be as diverse as the number of faculty and students: techniques differ from discipline to discipline, class to class, and person to person (Hassan, 2015:13). Yet he could concede that there are certain commonalities, a base, for the method.

I am a perfect example of Harkness's success. In the fall of 2016, after teaching many frustrating elementary Spanish courses at an American abroad program in Spain, I was given a higher proficiency Spanish course to teach. On my first day of class and after the first look of my varied and small class of students, I decided that it was now or never. I was able to "do Harkness" by teaching Spanish through the genre of the personal essay. I enjoyed the teaching of a language for the first time, I also developed and grew as a teacher, and finally, I got the best reviews ever!

Now when I asked the head of the Modern Language Department at PEA, how a new teacher would learn the method when they first teach at the Academy, she said that they would sit at as many classes as possible, that other teachers would share their knowledge in the method. And yet there is a freedom in the way you conduct a discussion-based class. 
Some shared features in a Harkness class despite different disciplines are:

- The student, even more than the teacher, must be responsible for learning. "This bedrock belief predates even the advent of Harkness teaching...Principal Benjamin Abbot, who led Exeter for 50 years from 1788 to 1838, believed that "The student must prepare the lesson; the student, not the instructor, must answer the question. That, perhaps, as much as anything, was the secret of his success as a teacher." (Crosbie, 1923:63).

- Although not all students might be talented even in one discipline, they are expected to work hard. However, gifted students are allowed to move at a greater pace.

- The student learns from others and about themselves helped by the fact that students and the teacher sit together around an oval table (the Harkness table). From this position of physical equality, the teacher no longer takes complete charge of directing the conversation; students can and must take responsibility for their participation within the group. A unique Harkness table that could accommodate 18 students was designed for Southridge School in Surrey, British Columbia. Made of solid wood and able to be pulled apart occasionally for collaborative work. (Hassan, 2015:226) ${ }^{2}$

- Elimination of "the delivery of something memorized," instead establish "serious consultation or discussion" is what Principal L. Perry and E. Harkness agreed:

\footnotetext{
${ }^{2}$ Annex 9.1 Different Versions of the Harkness Table: Figure 5: Wellington School, UK, Harkness sans table and Figure 6: At Lawrenceville School new tables can be divided too.
} 
The greater class discussion inherent in the conference plan would train each boy gradually to learn to talk and think while he was talking... The successful teacher in the plan would be not a drill master, but a partner in the human enterprise." (Hassan, 2015:13)

The focus then should be on learning, not teaching. For this purpose, teachers give a solid academic backing with well-thought content and an open-ended combination of inductive and deductive actions. (Respecting the Pupil, 1981:5). This collaborative effort relies on a shared text from which, and back toward, discussion arcs. What the discussion bring will depend on the choice of content, that is why planning is critical. (Hassan, 2015:130).

- Students are considered "able," responsible, and respected based upon Ralph Waldo Emerson's belief: "Our own experience dictates that the secret of education lies in respecting the pupil." (Ralph Waldo Emerson, 1883, Education.) and yourself. This mutual respect between student and teacher contributes significantly to a successful Harkness class. Even though criticism is essential, the way it's communicated, "without a dismissive or condescending tone, is all-important. (Hassan, 2015:16). Students are directed to correct one another, and encourage to think up ideas on their own. "Directed" is the important word, teachers that want to Harkness in their class, need to understand that students are not called for answers rather they are "directed" to add to a classmate observation for instance, to build knowledge together. "I feel like I fail when I offer an insight or ask a question that leaps too far, too fast." It shuts down the process of discovery, especially it it's not a true question, if I already know the answer" (Hassan, 2015:121) "...the skill of critical thinking is the goal rather than simply the capturing of a body of 
knowledge....when they nail it, they can feel the satisfaction of a discovery they have made mostly on their own." (Hassan, 2015:131-134)

- Dealing with silence in discussions. Teachers at PEA "believe that educating the talented is a cooperative enterprise in learning in which students and teachers work together and respect one another." Also, for students, the teacher is "a partner in learning, a subtle combination of questioner, inspiration, scholar, and colleague" who uses different inductive learning strategies for learners' own findings. Although difficult initially, the teacher must take a back seat and let the student play the most active part in the class, and as Norval Rindfleisch indicated, they should not be afraid of moments of silence (Essays on teaching able students:4). This latter recommendation was one of the most helpful I read for my own classes. Teachers and students alike are used to the lecture's word filling every minute of the class period. As he notes: "In the few chances for silence, I have made sure to let the sound of quiet sit so that everyone also knows the valuerather than embarrassment-of our shared silence...most importantly, just as I have worked to have the students trust each other and me, I have worked to trust them. (Hassan, 2015:71).

In my particular course initially, students felt that something was missing since they were expecting me to deliver all the information (including the meaning of words as a teacher dictionary) in class. It took another week for them to understand and adapt to the new learning method, whereas I will direct them to learn, but it was them that ultimately should do the learning. There is also the possibility of intrinsic in any (Socratic) debate of 
degenerating into an argument. That is when the teacher's experience will help get the discussion back on track. What I observed when I participated in classes at PEA was students getting off-topic on occasions, and the teacher directing the students back on pretty quickly. Sometimes they would be asked to do some work on the boards or reread a passage.

- As I witnessed at the Academy too, students become involved actively with the content at hand; they make discoveries together, a teaching practice that permits and motivates "students to uncover their own intellect through informed, intense, yet respectful dialogue." (Hassan:16). To aid individual and group work, they are also taught the process of investigation: "Harkness often encourages intellectual humility; it shows students that the richest way to learn is by asking questions, rather than jumping to conclusions or trying to furnish correct answers." (Hassan, 2015:122).

- Alongside there is the intention of educating the student as a whole individual: mind, body, and psychological well-being in ways that will encourage them to care for others. "...if we guide them towards compassion as well as intelligence, if we help them gain confidence in themselves, then we will be teaching as we should." (Respecting the Pupil, 1981:6).

Like Socrates, the teacher is interested in mental processes, in the student's growth as a thinking, feeling, changing human being, not merely in the student's ability to assimilate information. (Respecting the Pupil, 1981:11). 
- The importance of student writing in all disciplines is an essential characteristic as it is considered "the most active of all intellectual tasks" (Cole:4). In all language classes that I observed during the summer of 2016 , students brought their own notes or homework, and they would share them with their classmates by writing them on the blackboard. "Exeter made students write and write, express and express, until they honed their inchoate thoughts into readable prose" (Stephen G. Kurtz, Hassan: 60).

Today's interest in the latest "flipped classroom" denomination at universities is nothing else than the Harkness pedagogy of students coming to class with enough preparation to be able to own and discuss the topic of the day. No more memorizing facts without context.

- Diagramed conversations. In another class at PEA, I saw a teacher crisscrossing over an oval figure representing the Harkness table. It was a diagram of the conversation. Each dot depicted a student and the lines connecting them to their interactions. You can learn by looking at it who talked too much or too little during class discussions and then balancing it (Hassan, 2015:180). 


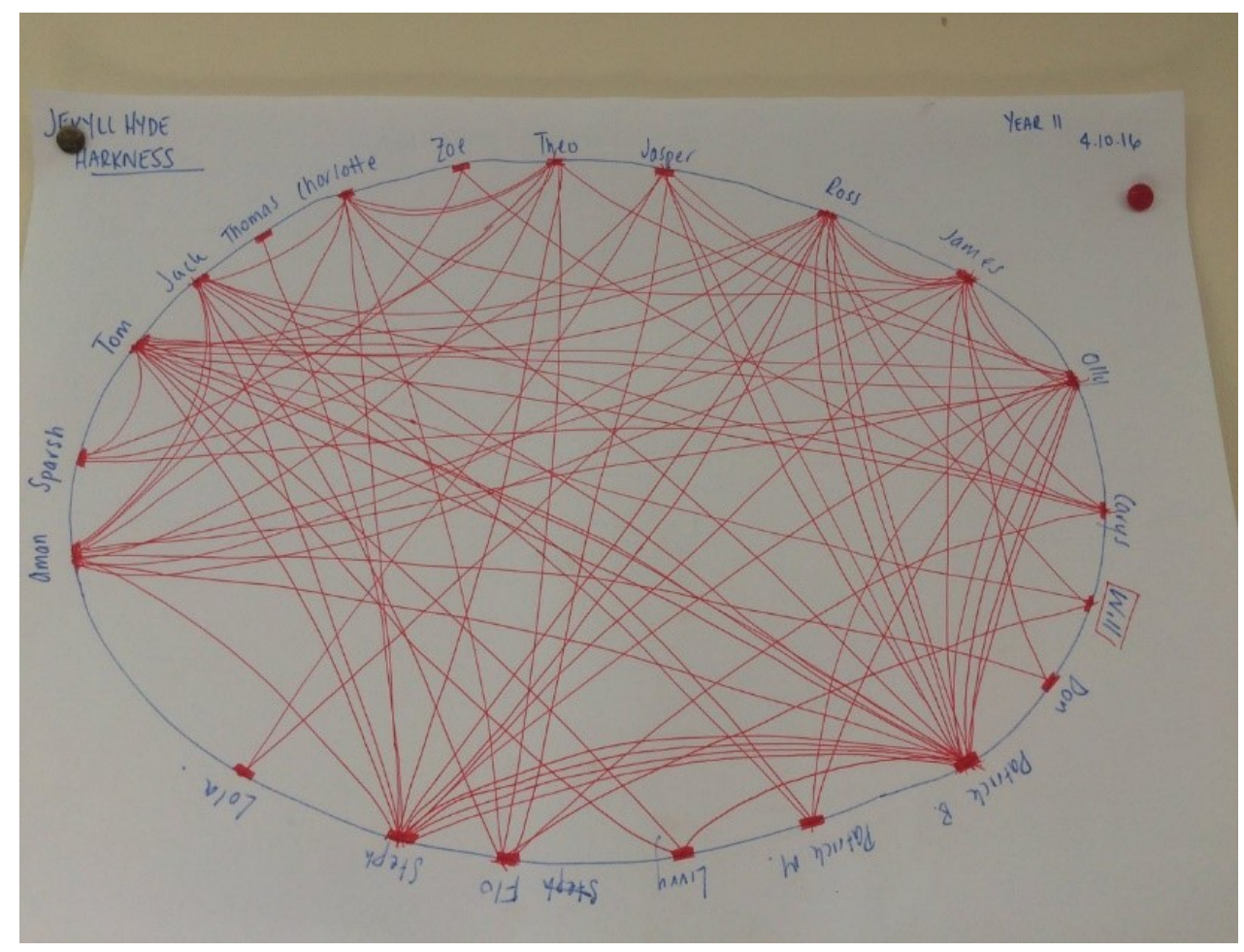

Figure 7: Diagram Conversation ${ }^{3}$

Still, the Harkness discussion is not a competition for the superiority of ideas. There are other things like compassionate listening, encouragement, kindness, and always room for mistakes and pauses. (Hassan, 2015:182)

There are several essays in a few books compiled from teachers of PEA that are a fountain of information about their experience in the Harkness table from every discipline. A common thread exists to stimulate and stretch students beyond their own sense of potential, like Olympic athletes, that would certainly challenge any teacher in return (Respecting the Pupil, 1981:5). I chose the following subjects because I found that their teaching and learning strategies could be applied to SLA.

\footnotetext{
${ }^{3}$ Harkness Table Notes in Annex 9.1
} 


\subsubsection{Religion, Music, Latin, and Performing Arts}

At PEA, religion is taught both by serving as school's chaplains and expressing different theological views in class, being careful not to impose their judgments. (Respecting the Pupil, 1981:24) An advantageous standpoint when dealing with different cultures too.

The method they use in all religion courses follows the Harkness system of teaching in many ways. For instance, in studying an introductory New Testament course, they begin with the text itself (the primary source), analyzing chapter by chapter. Hence, students "confront the mind of the biblical authors, understand the circumstances of their society, and identify their purposes in writing. (Respecting the Pupil, 1981:25)

Secondly, students write the outline or action of a chapter and thereafter their interpretation in a daily journal which the teacher reads daily to evaluate their understanding.

With this combined approach, they can uncover "underlying messages" individually, which sparks interest, enthusiasm, and class discussions in return: "Each student knows that on a particular day it could be his contribution that will become the key in this joined effort" (Respecting the Pupil, 1981:26-27). How do you create this level of enthusiasm in a language class or make a joint effort work in SLA? I found journaling to be a handy tool to reflect on the whole immersion experience abroad.

Sometimes even original interpretations of old problems take place on the table. In SLA, that also happens when you reach advanced language skills, and students can read and study original literary texts. 
In the religion discipline, perhaps more than in others, the teacher needs to be prepared to provide students with an extensive background concerning the oral tradition, geography, first-century culture and history, information about Old Testament references, the significance of Greek vocabulary, and more. (Respecting the Pupil, 1981:27) The SLA challenge is to devise a curriculum where the students can investigate and own their material while learning the necessary tools, the grammar, in an open-ended manner.

The question of talent pervades both music and languages. Teachers of both disciplines need patience and kindness dealing specially with beginners' levels. SLA consists of many elements, and many times we hear complaints of not being talented for languages. Is it the listening, memorization, pronunciation, or grammar that individuals fail? We, as teachers, find a total ignorance of what does entail and an unrealistic expectation of the time needed to acquire a second language. It does not help either the fact that many students are not familiar with grammar terms in their native language. Is there a specific talent for it?

For Exeter's classic language teacher:

...linguistic, like musical or artistic, aptitude can be something distinct from verbal or mathematical talent ... among the linguistically talented there appear to be two "skills." The intuitive skill, or as we in modern languages define it as having" a "good ear" can be recognized when students get the meaning of a text just by looking at the words in a dictionary without much grammar knowledge...the user of this skill often makes small errors and is sometimes completely wrong...he does...read more rapidly than other students and usually with better general comprehension." (Respecting the Pupil, 1981:90).

On the other hand, with the memory form/grammar skill, students learn and remember with accuracy tenses and other grammatical endings "and use them to deduce the meaning of the passage as he works through it more slowly. 
He must be encouraged to read less analytically and with more regard for sense, just as his opposite number must be persuaded to develop an eye for detail. The two types can, however, coexist in a class and they learn from each other's strengths." (Respecting the Pupil, 1981:90).

Learning by doing, being through discussion or in the written form, always has a longerlasting effect. As far as grammar, it is not dissimilar to the study of harmony or maths, "all can be tedious but need not be." (Respecting the Pupil, 1981:85).

Since we depend on a knowledge of many rules and correct applications, students are frustrated because at least with languages at the beginning, they have the articulation of a two-year-old.

Like music were performing also makes better teachers, teaching language from a learner's point of view is an advantage as it makes them more sympathetic to the obstacles students face:

Performers must perform and teachers must get new ideas, for the teacher-performer (teacher-writer) who can no longer learn should be buried alive, or at least retire early. This combination should serve as an inspiration and as an example for students. (Respecting the Pupil, 1981:86).

For Matthew Campbell, Performing Arts Master at LS, supported feedback is essential. When students are given structured opportunities around thoughtful feedback, they care more for their work, and that caring in turn fosters inquiry and even grit. It refines their understanding and challenges them to meet this newly realized level of excellence." (The Lawrenceville, 2015:20).

In Jake Morrow's Latin classroom, students do not prepare texts ahead but read a Latin text aloud, translate it into English, and discuss its distinctive characteristics as a class, becoming a "little community of Latinists learning together" (The Lawrenceville, 201515). 
To achieve this, students take turns as readers or helpers who take notes. It is the reader's responsibility when finish to ask for volunteers, or if none, to select a classmate. Together students accumulate more ability and have a higher probability of solving problems for themselves. In doing so, they also learn more thoroughly "than if they had simply heard the answer from me... and become a lot more confident in their own abilities. And that is - as I understand it - what Harkness teaching is all about." (The Lawrenceville, 2015:16).

\subsection{Role of writing in the Harkness class and in developing advanced foreign language literacy}

The seminar discussions serve as a rehearsal for the writing, and the writing experience reciprocally deepens the student's appreciation of craftsmanship and the power of the word." (Respecting the Pupil, 1981:13).

Norval W. Rindfleisch, an English teacher at PEA, reminds us of the inhuman Victorian school system and its terrible lasting effects described in Dickens Hard Times, devised as well to highlight the opposite to education of respecting and treating students with kindness. ((Respecting the Pupil, 1981:11).

In a language class, there is little time to build a community of student learners. The first thing for the instructor is to identify what materials, methods, and character will work for this particular combination of students: "Will this class be serious, playful, stubborn, willing? Will these separate voices find a new common language in an unfamiliar voice?" (Respecting the Pupil, 1981:72). 
The typical shyness and fear of ridicule that stems from learning to speak with new sounds, making grammatical mistakes, and communication misunderstandings are present in every student. Hence, our first job is always to establish an atmosphere in class where errors are considered stepping stones to deeper learning, where students feel confident enough to take risks and help each other as a matter of fact. It becomes allimportant also to tell them when they have done something well.

With seminar Harkness learning, the traditional grammar fill-the-gap tests conflict with the method. On the other hand, writing complements it and, as with the teaching of English, should be the principal method of evaluation. At PEA's English department, their writing program is combined with reading, but it is not an isolated activity.

In language classes, the connection between reading and writing must be explained, particularly in the lower levels, where we need to emphasize the correct form. However, it is essential to present texts that inspire, not just to model after, so there is room for individual creativity.

Now if the teacher takes the time to get to know the students' interests and then looks for materials accordingly, they can be used creatively in class:

To lead each class from structured to an innovative use of the language, to devise activities that progressively minimize the participation of the teacher, to supplement texts and exercises require much thought and planning. (Respecting the Pupil, 1981:80).

The instructor soon realizes that not a single textbook or literary work will deliver the class content with Harkness. I find that it is a very creative process for the instructor, as well. Organizing the syllabus by a sequence of genres and themes, with forms always in mind, expects to increase the quality of students' writing as much as possible. Although the content will not work if it causes it to be too challenging or too immature for students. 
Many of the required textbooks at the lower levels discourage beginners with senseless dialogues or absurd stories, but even at this level, it is possible to introduce genres and texts "so that the students are exposed to the living language," (Respecting the Pupil, 1981:74) through primary sources.

In my class, students write personal essays about events and characters in their families or descriptions of places they visit in journals, which go well with the sentence structure and vocabulary they are learning. In turn, they also acquire a truthful sense of its use, which feeds their writing and speaking.

Progressively with the application of genres students write first about what they know best, their families and home, and begin to explore what is their position, form their opinions, in this new society they are immersed. Ultimately the content is theirs.

With Harkness, we do not teach values directly, but the class is exposed to themes that have the power to "move us to feel or think, to stimulate our imaginations" (Respecting the Pupil, 1981:112). In my class, for instance, we always have the time to watch Diaries of a Motorcycle. Based on Ernesto (Che) Guevara's diaries about a trip on his old bike with his best friend around Argentina, Chile, and the North.

Through his young eyes, we see a society with an elite and a majority of impoverished populations struggling to make a living. The music, the different landscapes, and topics of this young road movie inspire students to discuss and write their own take on society. 
At the end of the course, they are used to writing drafts, correcting their errors, and then invariable feel more confident and prouder of their improved work:

...frequent confrontation with that blank space - often daily - probably produces more moral courage than any playing field. Because writing is perhaps the most complex of all human activities, making errors goes with the territory. errors gradually disappear only over a long period of constant and frequent correction" (Respecting the Pupil, 1981:22).

When you teach writing and reading in the English and language classrooms, students are acquiring at the same time the mental "processes that underlie these basic skills perception, cognition, imaginative manipulation" (Respecting the Pupil, 1981:15). Invaluable abilities for second language acquisition.

Student as teacher, teacher as student, the student bearing the laboring oar, and respect for one another these elements shape the character of our Harkness-based school." (Hassan, 2015:16).

In the winter semester of $2018-2019$, I was hired to teach at PEA. It was the realization of a lifelong dream, indeed. The following is an example of the first instructed composition assignment and model for my class at the second sequence of Spanish I level. Even with only present verb forms, it is possible to create a personal essay assignment that achieves meaningful results. 
TAREA

Tus Vacaciones. Describe lo que vas a hacer en tus próximas vacaciones. Utiliza estos verbos de la lista e intenta no repetir ninguno:

$\begin{array}{llllll}\text { jugar } & \text { poder } & \text { Preferir } & \text { querer } & \text { visitar } & \text { Volver } \\ \text { dormir } & \text { ir } & \text { pensar+infinitivo } & \text { ver } & \text { traer } & \text { querer+infinitivo } \\ \text { comenzar } & \text { conseguir } & \text { encontrar } & \text { entender } & \text { suponer } & \text { repetir } \\ \text { salir } & \text { seguir } & \text { perder } & \text { empezar } & \text { decir } & \text { Almorzar }\end{array}$

Tu redacción debe incluir:

1)Vocabulario de Cap. 4 y otras palabras que tú quieras.

2)Cuantas más palabras de transición mejor:

Siempre=always Nunca $=$ never Generalmente, frecuentemente, normalmente

$A$ veces $=$ sometimes $A$ menudo $=$ often También $=$ too, also Tampoco $=$ neither

Sin embargo $=$ however Por eso $=$ for that, because of that Entonces=therefore

Afortunadamente=Fortunately Desafortunadamente=Unfortunately Todavía=still

La redacción debe contener 100-120 palabras (10-12 frases) y tener 3 partes: Introducción, Cuerpo (body), Conclusión.

Esta redacción será el primer bosquejo o borrador en preparación para (después de recibir el primer borrador, draft, corregido por mí) escribir la primera composición EN CLASE.

Fecha: enero 2019

LA NOTA (grade): Tu composición final va a ser evaluada por 1.) el contenido, 2.) el seguimiento (following) de las instrucciones, 3.) el uso correcto de la gramática, y 4.) el vocabulario.

\footnotetext{
${ }^{4}$ Worksheet 1 PEA Samples in Annex 9.4, p.265
} 


\section{EJEMPLO}
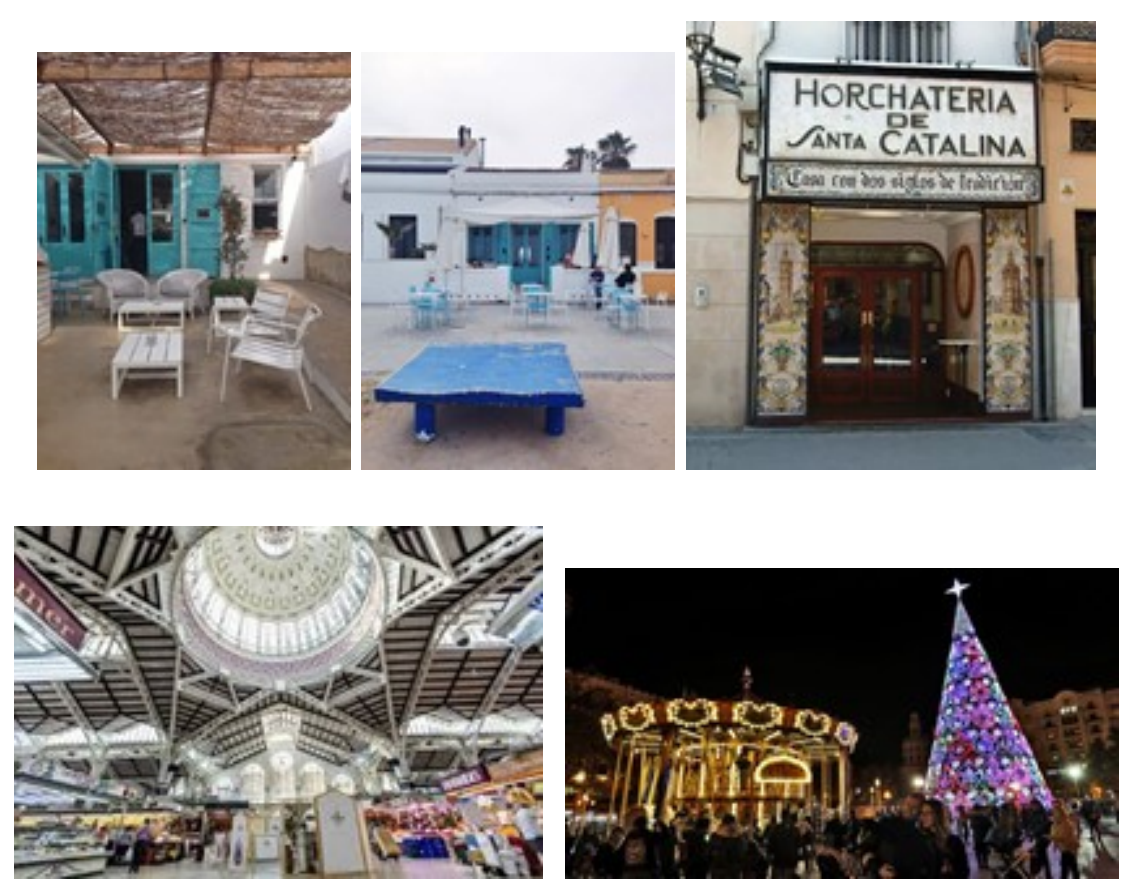

Durante mis vacaciones en Valencia pienso ver a mi familia y pasar tiempo con ellos, es muy importante para mí.

Por supuesto quiero comer los dulces tradicionales como los turrones y mantecados, aunque la verdad ¡yo prefiero un buen bocadillo de jamón serrano!

Normalmente vamos un día a la playa La Patacona para pasear y almorzamos luego en el restaurante La Mas Bonita. El tiempo es agradable y todavía no hace demasiado frío. También volvemos a lugares que nos recuerdan nuestra niñez, como por ejemplo la antigua horchatería de mis bisabuelos Sta. Catalina para comer chocolate caliente con churros y al precioso Mercado Central, en el centro, donde comienzo las compras Navideñas.

Otras familias con niños pequeños quieren ver las luces en la plaza del ayuntamiento y subir al carrusel o ir a la feria. No entiendo como disfrutan con tanta gente, nosotros sin 
embargo conseguimos llegar a casa donde finalmente empiezo a preparar la cena. Más tarde charlamos y jugamos a 'cucharas'.

¡A veces dormimos doce horas! Por otro lado, para eso están las vacaciones, espero traer energía renovada a Nueva Hampshire.

\section{Prompts and Model Translation}

-Your Holidays. Describe what you are going to do on your next vacation. Use these verbs from the list and try not to repeat any:

-Your composition should include:

1) Vocabulary of Ch. 4 and other words that you want.

2) The more transition words the better:

- The essay must contain 100-120 words (10-12 sentences) and have 3 parts: Introduction, Body (body), Conclusion.

-This essay will be the first draft in preparation for (after receiving the first draft, draft, corrected by me) writing the first composition IN CLASS.

Date: January 2019

THE GRADE: Your final composition will be evaluated by 1.) the content, 2.) following the instructions, 3.) the correct use of grammar, and 4.) the vocabulary.

\section{EXAMPLE}

During my vacation in Valencia I plan to see my family and spend time with them, it is very important to me.

Of course, I want to eat traditional sweets such as nougats and mantecados, although the truth is that I prefer a good serrano ham sandwich!

We usually go one day to La Patacona beach for a walk and then have lunch at La Mas Bonita restaurant. The weather is nice and it's not too cold yet. We also return to 
places that remind us of our childhood, such as the old Horchatería of my greatgrandparents Sta. Catalina, to eat hot chocolate with churros and to the beautiful Central Market downtown, where I start my Christmas shopping.

Other families with young children want to see the lights in the town hall square and get on the carousel or go to the fair. I do not understand how they enjoy it with so many people around, we however manage to get home where I finally start to prepare dinner. Later we chat and play 'spoons'.

Sometimes we sleep for twelve hours! On the other hand, that's what vacations are for, I hope to bring renewed energy to New Hampshire. 


\section{Writing emphasis}

The reading-writing connection between culture and knowledge learning has been investigated in many academic works. In 2001 Grabe distinguished reading to learn, writing to learn, and reading and writing to learn, but not the nature of the actual content learning in writing displayed or facilitated.

Leki and Carson, on the other hand, found that "text-responsible writing" is likely to produce better results in ESL writing programs than the open-ended assignments that have dominated instruction and assessment (1997:55). Instructors should aim to develop textual analysis and resources for students' writing, which will provide them with an advantageous direction: learning to speak, read, understand and write at high levels of ability to deliver content and knowledge that is meaningful to themselves and others.

Halliday explained how each mode of meaning-making from spoken language to writing operates with a complexity of its own. According to him, they are neither more complex nor more integrated:

...speech (appears), flowing, oriented towards events (doing, happening, sensing, saying, being), process like; writing on the other hand as structured, dense, oriented towards things, entities, tight and crystalline, with meanings related as components (Halliday, 2002a:350).

In general, oral language has more grammatical intricacy, more clauses per sentence as opposed to a written language that has low grammatical intricacy but high lexical density, more words in the total words of a clause, and "because the number of nonlexical items, grammatical words go down the written language tends to display a high degree of Grammatical Metaphor, its single most distinctive characteristic" (Halliday, 2002a:347). 
At some point in the written process, there is a move toward more written forms of language that involves increased clause and T-unit length that is obtained through the causal elaboration of participants and circumstances, premodification, and post modifications of grammatical metaphors and prepositional phrases.

The objectives of this chapter are:

- To understand writing as a form of meaning-making texts applied to SLA.

- To connect the curricular progression to a theory of learning.

- To envision a curriculum that focuses on genre along with learning a second language.

A genre approach can deliver the instruction for writing, and Systemic Functional Linguistics (SFL) theory that follows explains this connection like no other.

\subsection{American and other research on second language writing development}

If reading is certainly more active than watching a screen, writing is several times more engaging than reading:

What one reads has already been ordered, selected, evaluated. In writing one must do the ordering, clarify the relations of ideas and the relative importance of evidence and arguments, select an effective rhetorical strategy, choose words for clarity, precision, and tone, and select appropriately subordinate structures to mirror subordinate content." (Respecting the Pupil, 1981:15).

In SLA, these selections and some vocabulary must be exposed to learners. While it is assumed that FL departments teach already literate students, uncovering various 
discursive applications can help prevent the incongruous transfer of literacy practices from L1 into the L2 (Kaplan, 1987). But at advanced levels transferring writing abilities "from a well-developed, prestigious language to a second language studied in an academic context" requires more than "simple transfer of 'common' literacy skills" (Valdes, Haro, and Echevarriarza, 1992:348)

For advanced writing abilities at the textual levels, students have to be taught ways to develop beyond lexicogrammatical resources. Texts in sociocultural contexts are too extensive to develop a scope and sequence, the construct of genre, on the other hand, can offer key criteria for a writing curriculum.

The objective of literacy in L1 education underlines the need to ensure that learners obtain a comprehensive sense of the language system in order to be able to apply the meaningmaking resources of the language successfully. However, the policies to implement it in education prior to university are not very successful, and as I experienced first-hand with my students, they indicated they were never taught English grammar. The SLA teacher also becomes the language teacher.

On the other hand, in ESL, concerns focused on access to a range of educational opportunities for linguistic minority and immigrant groups. Reading and writing abilities tended to be seen together because both types are acquired simultaneously in young learners' educational development.

Hirvela emphasized the importance of reader-response theory together with providing textual models for a writing pedagogy for university ESL students (Hirvela, 2004). However, FL learners are likely to require considerably more detail about language form 
concerning textual meaning-making for the construct of literacy to facilitate FL writing development.

In FL studies for Hispanic heritage speakers, Valdes pointed out the tensions between what she called an ideology of the "use of English as the only language in which instruction is offered" (Valdes, 2004:69), and individual languages (Spanish stands out), that are designated as foreign, some as second, while others are taught in a heritage language setting.

The second older notion of literacy into FL education designated the ability to read and write in an encoding and decoding tradition, treating writing primarily to display knowledge of language forms. As Bernhardt concluded, "second language learners...essentially have to 'read to learn' and 'write to demonstrate learning.' (Bernhardt,1991:249).

The academic articles about literacy and foreign language teaching and content by Kern (2000) and later and by Swaffar and Arens (2005) offered an agenda for how literacy might reshape discussion in the field and what difficulties are likely to encounter. For them, a language in FL educational contexts must be understood as socially, rather than individually, constructed with overall textual orientation.

Kern demonstrated the lack of communicative competence, as it was and is interpreted and practiced, as the framework of reference for language teaching. He aimed to "reconcile communicative language teaching approaches...with the development of learners' ability to read, discuss, think, and write critically about texts" (Kern, 2000:5). For him, communication occurs "at the intersection between languages and context and relies on the perception of linguistic, cognitive, and social relationships," enabling "a 
mutually reinforcing relationship between literacy and communicative ability" (Kern, 2000:45).

The resultant pedagogical focus presented writing development through diverse stages of process writing (mapping, teaching genres, using models, and revising and editing) and as a choice of writing activities (Kern, 2000:191), from an emphasis on precise accuracy to an emphasis on content and ideas.

On the other hand, for Byrnes, advanced forms of literacy remained unreachable due to the structural limitations and due to the enormous influence exercised by commercial textbooks on a curricular imagination. (Byrnes,1998). She later focused on the relationship between syntactic and textual abilities via the grammatical metaphor (Byrnes, 2009a).

Swaffar and Arens considered the use of literacy as arising from scholars in literarycultural studies with an unusual interest in language learning and teaching and from their construct of literacy spanning their entire curriculum. The authors tied genres, at least conceptually, to different learning outcomes at different program levels that themselves could vary according to the choice of texts. It defined the differences in language studies as a discipline, but they did not explain how those language abilities would develop in support of textual meaning-making. (Swaffar and Arens, 2005).

For the semiotic meaning-making nature of language to be included in FL formal learning, which is at the heart of linking content and writing, a two-way learning relationship has to be established between the meaning-making potential of learners' available linguistic resources and how the latter enables them to expand their meaning-making capacities in texts. 
In 1996 Painter noted a symbiotic relationship between learning through language (the content) and developing language itself. It involves actualizing the semiotic systems of knowledge and language into text, reinterpreting the systems and new experiences in texts (Painter, 1996:80-81).

With the aid of a functional analysis of the grammatical system of language (functional theory of language), and that means grammar and lexicon combined, it is possible to devise a language-based approach to language learning and teaching (Halliday, 1996, 1999a, 1999b) and integrate content and language learning towards cross-cultural literacies.

Languaging, as defined by Swain (2006), expresses the active engagement of writers in meaning-making, the fundamental link between language and cognition, and the dynamic nature of a process whereby form-meaning choices are situated within a particular text, within a social context, and as many possible co-texts as examples of the total language system to which a piece of writing is referenced.

Kern and Schultz (1992) posed the question of how much change would occur in crucial features of writing development among students who received writing instruction over the course of one year in an intermediate French course. Whether students of a particular skill level evidenced greater or lesser change concerning other students in the same course and whether the students' writing's syntactic complexity increased.

Of interest are these findings: an overall syntactic development among low, mid, and high ability groups within the same course did not differ from September till February, then a sudden increase in T-unit length (a T-unit is an independent clause plus any dependent 
clauses) occurred, and a trend from the writing abilities of coordination to subordination to clause reduction developed.

Ortega's (2003) synthesis of 25 studies of college-level L2 writing, both ESL and FL, concluded that about a year seemed to be required for substantial changes in their writing's syntactic complexity.

An essential task for the FL writing field is investigating how specific syntactic characteristics are textually oriented measures of quality, as these characteristics are influenced by the writing tasks, including their generic quality (Byrnes, 2009a).

Decisions on the weighting of content and language might consider how to exploit background knowledge, and interests of collegiate learners to emphasize content earlier than the learners' language abilities alone would d otherwise indicate.

\subsubsection{Writing progress: syntactic abilities and textual meaning-making}

Hinkel 2002 corpus-based study of ESL writing (in which she tracked 68 lexical-syntactic and rhetorical items) found that these writers would need to expand their syntactic and lexical abilities to produce text "that was not merely knowledge telling but knowledge transforming" (Bereiter and Scardamalia ' s terms: 1987)

Instructors that seek to create a curriculum that supports its learners to advanced levels of writing ability must ensure that the learners can engage with texts through a pedagogy that creates sophisticated levels of awareness about HOW such writings themselves go about creating knowledge. 
Verspoor, Lowie \& van Dijk (2008) studied the relationship between the development of lexicogrammatical features and valued text types based on dynamic systems theory. Larsen-Freeman \& Cameron, on the other hand, based the orientation of written discourse with chaos and complexity theory. (2008a).

Still, T-units analysis and its related measures are not in themselves valid indicators of dynamic syntactic complexity that one should expect across different text types. If lexicogrammatical features are indicatives of a form of textual meaning-making, we must investigate the mutual influences on the development of a need to mean textually and the ability to mean by way of these features and how both develop over time. (Byrnes, 2009a; Christie \& Derewianka, 2008).

An important step away from a narrow syntactic focus came from an approach that looked for an arrangement of textual features, rather than isolated features, that would classify and differentiate large genre families, as in Grabe's expository and narrative texts (2002). Martin (2002a) presented a kind of curricular learner pathway: "cline of apprenticeship that moves from personal experience to deconstructive critique, ...from narrative to exposition in Grabe's terms" (Martin, 2002a:272).

\subsection{Systemic Functional Linguistics (SFL): a textual and functional interpretation of grammar}

Because of the need to consider the text-making consequences of syntactic development rather than merely observing it in isolation, the SFL research that "uncovered relationships between the availability of lexicogrammatical resources and the ability to 
produce valued academic writing, which involves clausal, complex clausal, and phrasal resources that enable forms of meaning-making granted in academic writing" (RyshinaPankova, 2006,167) is particularly useful for this study.

At present, the best developed textually oriented functional theory of language is SFL. How can SFL support learners' outcomes and the instructed development of advanced FL writing abilities?

Systemic Functional Linguistics is a theory of language that aims "to construct a grammar for purposes of text analysis." (Halliday, 1994:15).

\section{SYSTEMIC FUNCTIONAL} LINGUISTICS (SFL): Halliday

\section{- Systemic Model of Language Strata}

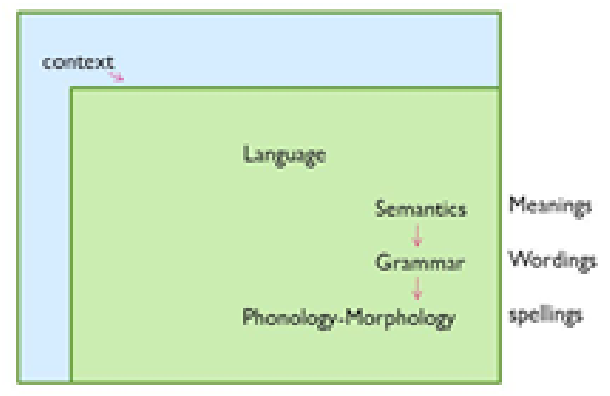

Figure 8: SFL by Halliday

A study of L1 English literacy development from childhood to late adolescence by Christie and Derewianka (2008), in the context of precollegiate education in Australian schools, used SFL to trace literacy development across an extended curricular progression. The focus on the relationship between linguistic form and textual meaning motivated a progression of textual genres across the grades to adulthood and established a link between textual abilities, cognitive development, and content knowledge. These tools can also be used for adult L2 writers. 
SFL understands language as being about meaning-making in oral and written texts and focuses on linking its linguistic theories to educational practice. It does so by enabling learners to develop an academic and working language, gaining knowledge on the process, and using the need to mean as a way of developing language abilities. Interestingly, my generation's second language learners were moved to acquire a second language by a sincere wish and attraction to foreign cultures or/and combined with a need while living in the target country. SFL creates if artificially, a need to advance language proficiency.

But it does not only explain aspects of language learning: "While it is important...to investigate how students learn how to write in a second language, it is equally important to learn how students learn a second language through writing" (Harklau, 2002:329). SFL understands language as a socially and culturally grounded semiotic system, which complements the kinds of translingual and transcultural competencies valued as educational outcomes for higher education in today's global age.

A focus on understanding and evaluating text in context results in grammar being understood as connecting lexicon and grammar into lexicogrammar.

It also interprets grammar as meaningful through wording choices, which serves as the material base for lexicogrammatical constructions and meaning.

In Spanish there are many examples with the verb to be forms ser/estar, depending which one it is being used the meaning of an adjective can convey different things that can only be understood through the complete lexicogrammatical context ((ser malo vs. estar malo, to be a bad person/to be sick). 
Grammar is, therefore, about situated choices being made in contexts, rather than rules being fulfilled. What goes together with what is essential, but we want to go further into what could go instead of what (Halliday \& Matthiessen, 2004:24) and the meaning of consequences.

Halliday formulated a way of relating grammar, language, context, and culture:

On the one hand, language "constitutes" human experience...the grammar transforms experience into meaning, imposing order...On the other hand, language "constitutes" social processes...the grammar brings about processes, and the order, through meaning. (Halliday,1996:7).

\subsubsection{Metafunctions and genres}

Language construes our experience in the world around us and in us in terms of "meaning as representation." Named the ideational metafunction, it expresses meaning in terms of Participants, verbal Processes, and Circumstances, using the simple and complex clause's transitivity system.

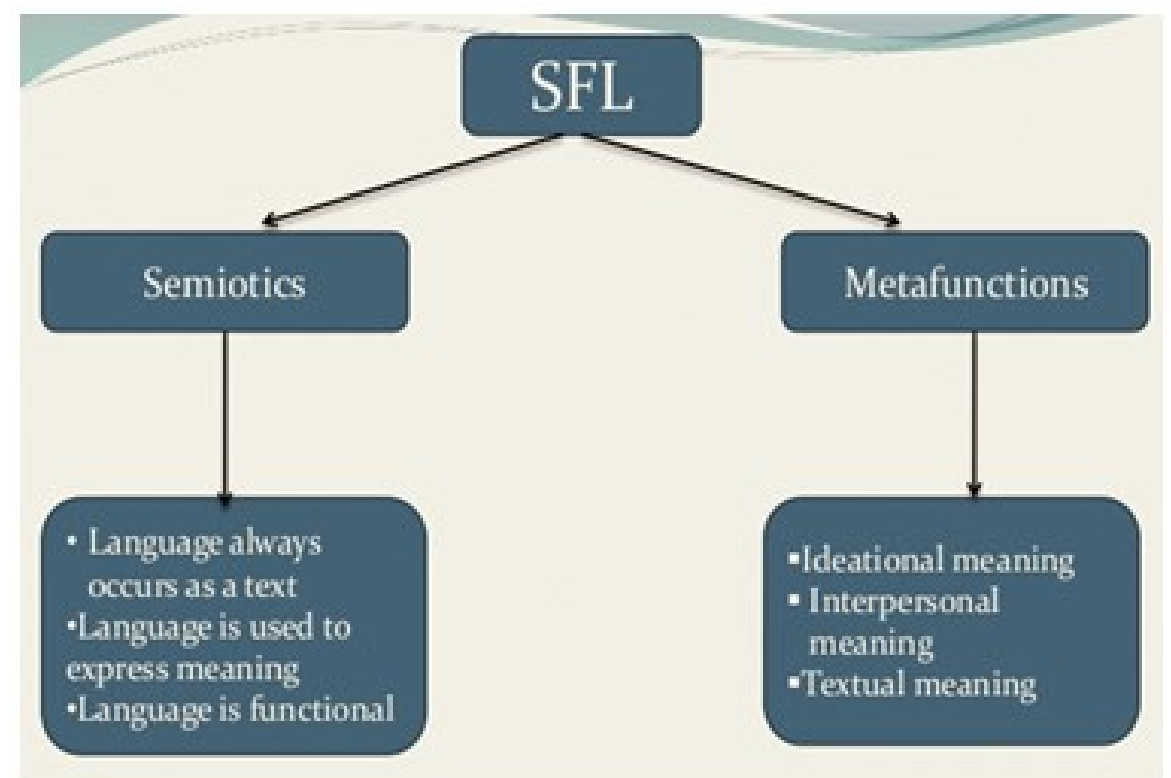

Figure 9: SFL Semiotics and Metafunctions 
Second, the interpersonal metafunction enacts meaning in terms of the personal and social relationships around us: It is language as action, through the grammatical systems of mood, modality, and appraisal, attitude, affect, judgment, and appreciation.

The third is the textual metafunction, which enables the first two because they depend on language "being able to build up sequences of discourse, organizing the discursive flow and creating cohesion and continuity as it moves along" (Halliday \& Matthiessen, 2004:30). As wording performs ideational and interpersonal functions, they must create the cohesion and coherence constitutive for a text.

\section{The 3 metafunctions of language}

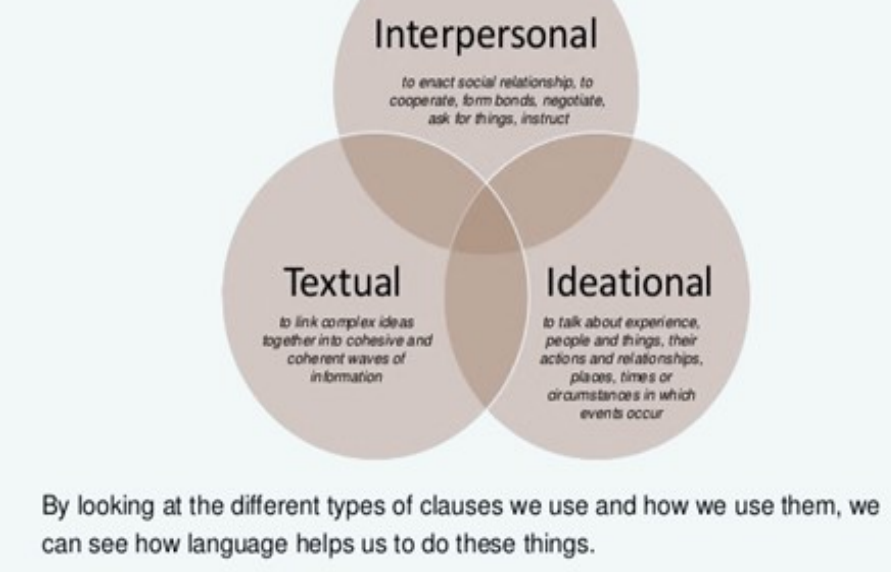

Figure 10: Relations of Three Metafunctions

Field, Tenor, and Mode are the three variables in all texts that SFL uses to connect them with their macro functions. Field addresses what is being discussed in terms of a situation's social activity, and Tenor refers to how social roles and relations are being enacted. Mode realizes both the ideational and interpersonal meaning in oral and written texts according to the opportunities and constraints inherent in speech and writing. 


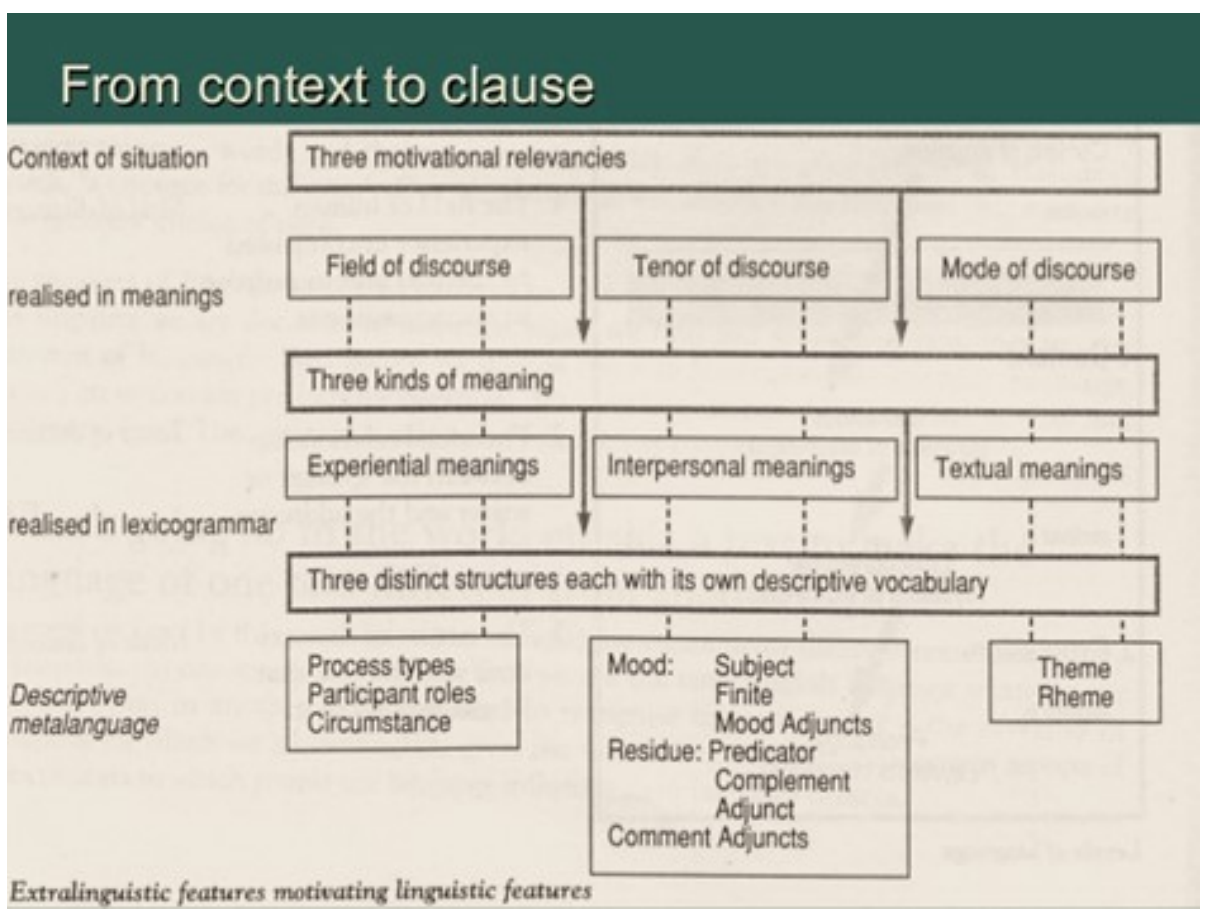

Figure 11: Extralinguistic Features Motivating Linguistic Features

These three variables are not separated from each other. Their outcomes "interact with one another creating bundles of lexicogrammatical features that construe a situation types such as academic writing, journalism, business trade and they are understood as text types as in research articles, reports, brochures. The resulting bundles are designated as register, and are open to adjustments in a particular context of situation" (Matthiessen, 1993:224).

SFL theory has been naturally inclined towards the construct of genre, which conveys the evidence of texts with its stylized language. For instance, there is a range within the memoirs or non-fiction genres that can be traced in tune with the SFL approach. SFL analytical tools are useful to describe the relations between the meaning potentials of semiotic situation types, semantic cultural domains, and genre-specific of a given text, in terms of language as a social semiotic. 


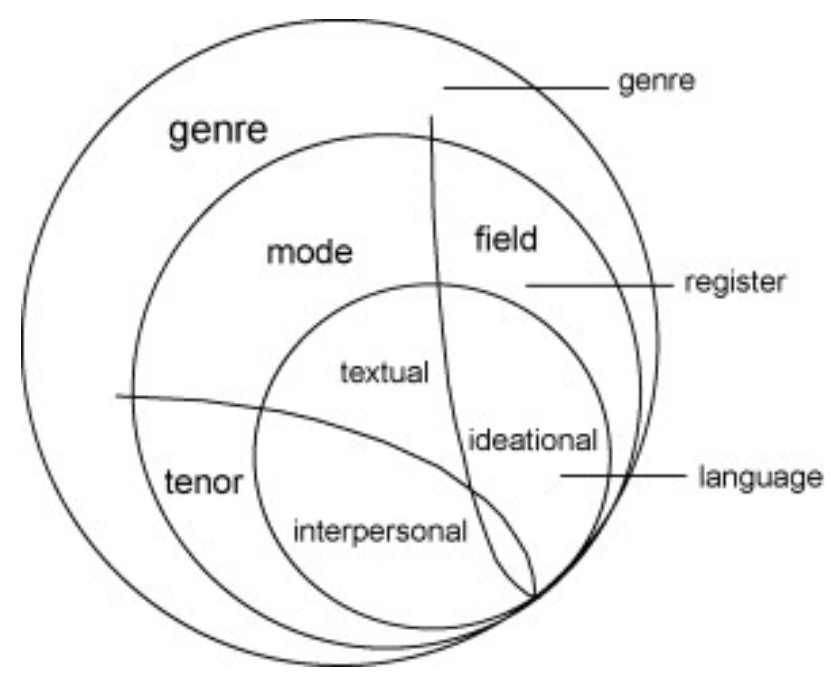

Figure 12: Genre, Register and Language

Genre as activity type, linguistically realized in text. Register as a functional variety of language, characterized in terms of bundles of features. As shown in the lower right of figure 12, any language use involves the ideational and interpersonal metafunctions realized through the text to make up the semiotic potential of language.

For FL writing, this focus and analysis of texts is of great interest. In SFL theory, genres are described in terms of linguistically realized activity types with these characteristics:

- They advanced through various phases of meaning in moves, obligatory, and optional that accomplishes the genre, they are staged.

- Steps within the moves are goal-oriented; they meet certain expectations.

- They occur in social settings and are interactive.

Martin summarized the best these qualities of genres:

Genres are how things get done, when language is used to accomplish them. They range from literary to far from literary form: poems, service encounters, news broadcasts and so on. The term genre is used here to embrace each of the linguistically realized activity types ...of our culture." (Martin, 2002a:250) 
We all agree that texts occur in contexts. SFL theory determines that texts are particular instances of the meaning potential of a language system. They become realizations of situations in the context of culture (e.g., a presidential inaugural speech) in this way, "If we have access to the context, we can predict the essentials of the text...if we have access to the text, we can infer the context from it" (Hasan, 1996c:42.). 


\section{Implementation of a genre-based instruction of foreign language writing development}

Macken-Horarik, in a series of case studies, observed commonalities in teachers' pedagogies that served to expand their students' awareness of what the subject demanded of them (thoughtful and situated choices). Through a set of terms that related literacy to learning, "teachers were better able to communicate intended learning goals to the students...better able to make pedagogical choices that referred back to the structure of written genres, better able to "semioticize learning" (Macken-Horarik, 1996:275). As mentioned before, writing underlines the connection between meaning and form better than communicative language teaching. An added benefit is that the material by its very nature is more traceable and thus easier to monitor and ultimately reflect on and analyze.

\subsection{The construct of genre}

The introduction of genre and its pedagogy as social-contextual features, enables FL learners to see content in terms of language right from the beginning, rather than integrating them afterward, this is the primary function in the instructed curriculum that follows. 
In 2004 Bazerman focused on the form-function question for L1 writing development:

Each successful text creates for its readers a social fact. The social facts consist of meaningful social actions being accomplished through language, or speech acts. These acts are carried out in patterned, typical, and therefore intelligible textual forms or genres, which are related to other texts and genres that occur in related circumstances. Together the text types fit together as genre sets within genre systems, which are part of the systems of human activity. (Bazerman, 2004b:311, original emphases).

As far as FL undergraduate programs it is reasonable to propose that genres could be prominent too, providing that it enables L2 learners to expand their linguistic resources beyond those characteristics of the dialogue exchanged in language instruction focused on developing speaking abilities to the increasingly more competent use of the language of academic writing.

FL teachers can begin to consider a variety of genres in terms of the opportunities for thinking for writing, similar to Slobin's (1996) perceptive idea of "thinking for speaking," that they would need to help students create advanced FL writing abilities: "learning to write and writing to learn are not separated (since)... writing is embedded in the array of learning tasks that the curriculum envisions for the classroom." (Byrnes, 2011:71-72).

Genre Theory highlights that in teaching writing, teachers need to pay attention to the processes of composing texts and the nature of texts that students write (Hammond and Derewianka, 2001:187; Koutsantoni, 2007). 
Table 1: Genres across the GUGD curriculum: From primary to secondary discourses

\begin{tabular}{|c|c|c|c|c|}
\hline & Level I & Level II & Level III & Level IV \\
\hline $\begin{array}{l}\text { Primary } \\
\text { discourses }\end{array}$ & $\begin{array}{l}\text { casual conversations } \\
\text { (14) } \\
\text { picture story (15) } \\
\text { cartoon strip } \\
\text { personal narrative (2) } \\
\text { recipe }\end{array}$ & $\begin{array}{l}\text { personal narrative } \\
\text { journal entry }\end{array}$ & $\begin{array}{l}\text { journal entry (4) } \\
\text { personal narrative (4) }\end{array}$ & \\
\hline $\begin{array}{l}\text { "Blurred" } \\
\text { discourses, } \\
\text { including } \\
\text { literary works } \\
\text { and other forms } \\
\text { of artistic } \\
\text { expression }\end{array}$ & $\begin{array}{l}\text { personal ads (many } \\
\text { in one newspaper } \\
\text { section) } \\
\text { culinary show } \\
\text { information enquiry } \\
\text { (3) } \\
\text { short descriptive text } \\
\text { song } \\
\text { myme (2) } \\
\text { poem (7) }\end{array}$ & $\begin{array}{l}\text { TV drama } \\
\text { personal essay (3) } \\
\text { autobiographical } \\
\text { portrait } \\
\text { short novel } \\
\text { poem (5) } \\
\text { song } \\
\text { literary fairy tale (4) } \\
\text { autobiographical } \\
\text { account }\end{array}$ & $\begin{array}{l}\text { short story (2) } \\
\text { poem } \\
\text { song (2) } \\
\text { novel } \\
\text { dramatic film (2) } \\
\text { short story/personal } \\
\text { narrative } \\
\text { autobiographical } \\
\text { account }\end{array}$ & $\begin{array}{l}\text { novel } \\
\text { poem } \\
\text { short story (within it: } \\
\text { formal letter/phone } \\
\text { conversation) }\end{array}$ \\
\hline $\begin{array}{l}\text { Secondary } \\
\text { discourses }\end{array}$ & $\begin{array}{l}\text { service encounters } \\
\text { (4) } \\
\text { weather report } \\
\text { report card } \\
\text { information text (2) } \\
\text { housing ads (2) } \\
\text { traveling ads (many in } \\
1 \text { newspaper section) } \\
\text { TV report } \\
\text { statistical report (3) } \\
\text { detective story/police } \\
\text { report } \\
\text { pros and cons } \\
\text { newspaper feature } \\
\text { article (2) }\end{array}$ & $\begin{array}{l}\text { biographical chronicle } \\
\text { artistic manifestos } \\
\text { newspaper article (2) } \\
\text { statistical report } \\
\text { descriptive texts } \\
\text { documentary film } \\
\text { short film (intro to } \\
\text { the city) } \\
\text { interview } \\
\text { magazine feature } \\
\text { article } \\
\text { TV report } \\
\text { documentary (3) } \\
\text { statistical report (5) } \\
\text { chronicle (2) } \\
\text { argumentative essay } \\
\text { short opinion poll } \\
\text { answers } \\
\text { short lecture } \\
\text { information text } \\
\text { brochure } \\
\text { encyclopedia article }\end{array}$ & $\begin{array}{l}\text { film review } \\
\text { documentary film } \\
\text { descriptive essay } \\
\text { historical essay } \\
\text { interview'personal } \\
\text { narrative } \\
\text { historical recount } \\
\text { historical chronicle } \\
\text { interview (3) } \\
\text { political appeal (3) } \\
\text { graphs/charts } \\
\text { slogans } \\
\text { newspaper article } \\
\text { news report (2) } \\
\text { political caricature } \\
\text { journalistic essayl } \\
\text { report } \\
\text { political cartoon (2) } \\
\text { political pamphlet (2) } \\
\text { blographical chronicle } \\
\text { chronicle }\end{array}$ & $\begin{array}{l}\text { surveys and question- } \\
\text { naires } \\
\text { chronicle } \\
\text { political speech (2) } \\
\text { historical narrative } \\
\text { reflective essay/per- } \\
\text { sonal narrative } \\
\text { information text } \\
\text { information text/ } \\
\text { instructions/glossary } \\
\text { academic compara- } \\
\text { tive article } \\
\text { editorial (3) } \\
\text { editorial/study report } \\
\text { formal interview } \\
\text { information text/book } \\
\text { introduction } \\
\text { essay (Feuilleton) }\end{array}$ \\
\hline
\end{tabular}

The above curriculum from the Georgetown University German Department (Byrnes, 2011) shows the genre of the personal narrative classified as primary discourse across the Primary Discourses at all levels. At level IV, is categorized as a secondary discourse and named reflective essay/personal narrative.

However, "While it is important for classroom-based studies to investigate how students learn how to write in a second language, it is equally important to learn how students learn a second language through writing" (Harklau, 2002:329). 
For Matthiessen, Teruya, and Wu (2008), the level of analysis likely to be most productive is found in the middle region between the individual instance and the system of language (with notions of register and text). There is a lot to learn from extended multi-year studies about what constitutes a substantial and targeted improvement in FL writing abilities and developing criteria and specific indicators that can trace exceptional development.

This study has done so basing the creation of a curricular pathway and the statement of expected learning outcomes and the major stages of the curricular progression in a way that can be supported by data-based evidence (Norris, 2006a).

A genre process is characterized by an original textual orientation. Hyland, for example, advocated a genre-based pedagogy in an approach derived from Systemic Functional Linguistics that "stresses the purposeful, interactive, and sequential character of different genres and the ways language is systematically linked to context through a pattern of lexico-grammatical and rhetorical features (Hyland, 2003a:21-22).

\subsection{FL learners writing selections}

Initially, tasks should recognize the current meaning-making capacities and push to develop further ones. A strong reading-speaking-writing link, with examples in classroom activities, is a critical component because texts provide models for the meaning-making resources available in the language system that could also reflect the cultural system. Lexicogrammar represents the heart of the meaning-making resources of a language. The difficulty lies in how to relate intended meanings to forms through lexicon and grammar in creating texts. These texts have to include a continuum of options too that 
are related to learners' evolving resources and shift throughout language learning at different paces in the acquisitional trajectory.

The linguistic aspect of genres is realized in three distinct and interrelated levels:

the discourse, sentence, and lexicogrammatical levels following the GUGD approach,

- At the Discourse Level, the focus is on rhetorical features (e.g., recounting, comparing/contrasting, persuading) and the text's organizational structure.

- At the Sentence Level, attention is directed to syntactic patterns required to achieve the communicative purpose text.

- At the Lexicogrammatical Level, the emphasis is on the specific and indispensable word and phrase-level phenomena: semantic, collocation, and formulaic expressions.

In my study, choices always have to do with both vocabulary and grammar. In a literacy instructed FL focus, through the use of texts in reading and writing you can link lexicogrammatical available resources to the three metafunctions of language. FL learners face additional challenges finding how the languages in question differ from their respective lexicogrammatical systems, primarily how they distribute ideational, interpersonal, and textual resources. FL learners will begin to understand that grammatical means that activate meanings, often hidden at the textual level, unlike lexical means, are also more consequential for the text's complete sense.

Eva Hoffman describes in her memoir the transition from Poland to Vancouver in 1959 at the age of thirteen: "...formica counter. The milk, homogenized, and too cold from the fridge, bears little resemblance to the liquid we used to drink called by the same name." 
(Hoffman,1989:106) The same name but different, partly a language memoir it is interesting to learn from her struggle with differences in making meaning in the new language:

There are some turns of phrase to which I develop strange allergies. "You're welcome," for example, strikes me as a gaucherie, and I can hardly bring myself to say it - I suppose because it implies that there is something to be thanked for, which in Polish would be impolite. The very places where language is at its most conventional, where it should be most taken for granted, are the places where I feel the prick of artifice". (Hoffman, 1989:106).

Furthermore, she later develops a profound language alienation at all levels to even question her very existence:

But mostly, the problem is that the signifier has become severed from the signified. The words I learn now don't stand for things in the same unquestioned way they did in my native tongue. When my friend Penny tells me that she's envious, or happy, or disappointed, I try laboriously to translate not from English to Polish but from the word back to its source, to the feeling from which it springs. Already, in that moment of strain, spontaneity of response is lost. And anyway, the translation doesn't work. I don't know how Penny feels when she talks about envy...It is the loss of a living connection. At night...In English, words have not penetrated to those layers of my psyche from which a private conversation could proceed. Now, this pictureand-word show is gone; the thread has been snapped. I have no interior language, and without it, interior images (My emphasis Hoffman, 1989:107).

For FL students, once they learn how to do things with words in the way the culture, they are in does them, they need to know when and where the power relationships, as far as genres are concerned, can be challenged to create a new text/identity. Textual meaningmaking involves many related areas of the lexicogrammatical system (Von Stutterheim \& Carroll, 2006).

In Eva Hoffman's case, she learned English through writing, "and, in turn, writing gives me a written self. Refracted through the double distance of English and writing, this self my English self-" she wrote is objective, it exists in her thoughts and observations and is 
somehow impersonal: "When I write, I have a real existence that is proper to the activity of writing - an existence that takes place midway between me and the sphere of artifice, art, pure language." (Hoffman, 1989:121).

Parodi proposed genres as cognitive structures because in the end "genre knowledge, which is both socially and individually constructed, is stored in the form of cognitive representations" (Parodi, 2010:22) ... "but may and must freely decide to adapt to the context and act within the framework in question" (p.26).

Genres present regularities that can be taught, both in analysis and in a motivated progression for language production. Any learner can analyze the moves that a given text covers. It is an exciting prospect as it can recognize the engagement of the multilingual learner and the consequences this engagement would have for the development of multiple literacies.

Accordingly, instructors need to make textual choices and devise writing tasks appropriate to the learner's level to acquire a valuable understanding of the language system in context. Textual choices are first and foremost educational decisions about what students can and should learn at a particular curriculum stage.

They are not opposed to interesting texts and writing for students, appropriately sequenced, they become key facilitators for writing development. In Halliday's opinion (1978), language is understood as meaning potential, what the speaker can do or mean, which implies that out of the different choices that are possible in language, the speaker selects the most appropriate ones according to the communicative situation. 


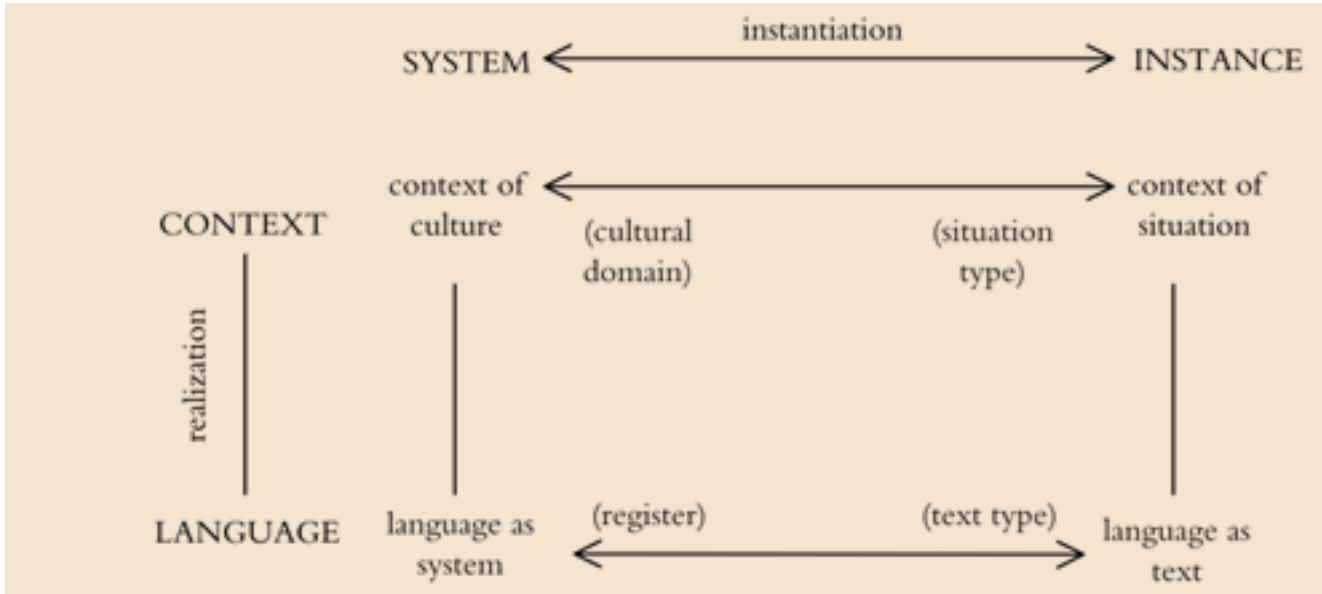

Figure 13.1 Language and context, system and instance

Note: Culture instantiated in situation, as system instantiated in text. Culture realized in/ construed by language; same relation as that holding between linguistic strata (semantics: lexicogrammar: phonology: phonetics).

Cultural domain and register are "sub-systems": likeness viewed from "system" end.

Situation type and text type are "instance types": likeness viewed from "instance" end.

Figure 13: Halliday`s Language and Context, System and Instance (1999b:8)

In SFL, as Figure 5.1 shows, the challenge is to create a "cline of instantiation" that "extends from text instances to the overall systemic potential of a language-from the acts of meaning that make up a text to the meaning potential that makes up the linguistic system. Matthiessen (Halliday, 2006:41-42, original emphases).

Moving up and down this cline is activated with writing tasks that draw on the meaningmaking knowledge available to a growing writer. How a particular text links up with the language system must become part of a developing FL writer's metalinguistic awareness (or insight into how texts come to mean) from early stages to more advanced.

It is a formidable challenge for teachers to devise writing tasks that enable writers to make an effort to increase their meaning-making repertoire and to attend to precise accuracy at the same time. Because of the level of language acquisition concerned, this study does 
not include genres that are metaphorical of the world in public life or the genres in academic, professional, and institutional settings.

\subsubsection{Example of a text progression with a series of historical genres}

Discourse, sentence and Lexico-grammatical Levels

Recounting, reporting, and narrative or story, genres that focus on the verbal system are the heart of what SFL refers to as agreement semiosis. These genres put to good use all aspects of the transitivity system -Participants, Processes, and Circumstances- in reallife situations: "first in simplex and then in complex clauses that gradually move from paratactic to hypotactic and embedded clauses, and from the expressions of temporal relationships to building up logical relationships." (Byrnes, 2011:64).

C. Coffin showed how the historical account genre typically develops according to three stages: background, account sequence, and deduction. (Coffin, 2006:59).

It's in the account sequence where the writer chronicles events as they unfold in the past time. Events play an agentive role in producing subsequent events. In the grammar, this is realized as nominalizations in initial clause (thematic) positions.

She presented a three-stage topology of history genres: The recording genres, the explaining genres, and the arguing genres. For each genre family, she listed their social purpose, identified stages in its unfolding, pointed out key aspects of language, and indicated semantic features foregrounded. Field, tenor, and mode considerations, as contextual variables, and typical textual stages (Coffin, 2006:64). 
This specification of the genre provides support for teachers and learners alike:

1. Recording genres focus on the narrative unfolding of events in time. Temporal sequences in structured narratives that may address different time frames focus both functionally and formally, from specific Participants to generic Participants, from concrete to more abstract events, including some language of cause and effect.

2. The explaining genres focus on explaining phenomena in terms of causes and effects. They use multiple factors in their explanations, as contrasted with the single-cause narrative of the recording genres.

3. The arguing genres address whether previously given explanations of a particular event or outcome are, in fact, likely to be valid.

Exposition argues for a specific interpretation, discussion considers different interpretations, and challenge argues against a particular interpretation. 
Genres in history

\begin{tabular}{|c|c|c|}
\hline Genre family & Genre & Overall purpose \\
\hline \multirow[t]{4}{*}{ Recording } & $\begin{array}{l}\text { Auto biographical } \\
\text { recount }\end{array}$ & To retell the events of your own life \\
\hline & Biographical recount & $\begin{array}{l}\text { To retell the events of another person's } \\
\text { life }\end{array}$ \\
\hline & Historical recount & To retell events in the past \\
\hline & Historical account & $\begin{array}{l}\text { To account for why events happened in a } \\
\text { particular sequence }\end{array}$ \\
\hline \multirow[t]{2}{*}{ Explaining } & Factorial explanation & $\begin{array}{l}\text { To explain the reasons or factors that } \\
\text { contribute to a particular outcome }\end{array}$ \\
\hline & $\begin{array}{l}\text { Consequential } \\
\text { explanation }\end{array}$ & $\begin{array}{l}\text { To explain the effects or consequences of } \\
\text { a situation }\end{array}$ \\
\hline \multirow[t]{3}{*}{ Arguing } & Exposition & $\begin{array}{l}\text { To put forwarda point of view or } \\
\text { argument }\end{array}$ \\
\hline & Discussion & $\begin{array}{l}\text { To argue the case for two or more points } \\
\text { of view about an issue }\end{array}$ \\
\hline & Challenge & To argue against a view \\
\hline
\end{tabular}

Source: Adapted from Caroline Coffin Learning the Language of School History: The Role of Linguistics in Mapping the Writing Demands of the Secondary School Curriculum, Journal of Curriculum Studies $38(4)(2006), 413-429$.

Table 2: Genres in History

Major history genres can be arrayed in a curricular progression with meaning-form relationships at all levels of the language system that characterizes the treatment of genres in SFL. Furthermore "texts can be chronologically organized according to the sequence of events they describe or rhetorically organized in terms of an unfolding argument" (Martin, 2009:14) and then divided into “distinct 'beginnings', 'middles' and 'ends'" (Martin,1997:413). 
These structural elements or stages can be identified based on shifts in lexical and grammatical patterning which correlate with different micro functions operating at various points in the text e.g., accounting for why events happened in a particular sequence followed by deducing the significance of the series of events (Coffin:4).

\subsubsection{Illustration of a series of memoir genres from the Spanish Civil War}

To illustrate how texts can be analyzed using the concept of genre, most of the following works, taken from my master's bibliography, belong to the recording historical narrative genre, specifically to the subtype of the autobiographical recount. The events may then be assessed in terms of their historical significance. (Coffin:4) It can provide a chronological account of the Spanish Civil War while at the same time drawing out some of the causal connections between events featuring language of time. Although the narratives are autobiographical, their primary social purpose is to witness the events that occurred during the war. To retell events in the past from someone that was actually there. It is easy to model a 'beginning,' 'middle,' and 'end' stages from many historical accounts in the genre forms of diaries, letters, memoirs, and articles. At the next level, individual narratives about the SCW can be juxtaposed with secondary genres focusing on the same events, such as chronicles, political speeches, documentaries, or historical accounts.

The genre of the memoir is nearly as old as writing. It dates back to at least the 5thcentury "Confessions" of St. Augustine through the fictional autobiography, the slave narrative, the Victorian memoir of John Stuart Mill, the criminal/lowlife memoir and the 
addiction/abuse memoir to name a few. However, it was not until the 19th and 20th centuries that the memoir became one of the dominant literary forms in the long history of American immigrant autobiographical writing.

In his book Memoir: A History, Ben Yagoda defines "autobiography" and "memoirs" as the effort "to be a factual account of the author's life," and memoir singular as books that cover only a portion of life (2009, Author's Note:1).

Textual Historical Background, Account, and Deduction sequence of The Spanish Civil War.

My Master's dissertation main purpose was to see the SCW as part of a larger historical pattern, to find an outside perspective of its place in world history. I attempted to do this through primary only sources of American witnesses' accounts of the SCW.

There were many different characteristics between the people from all over the world that joined the international effort in Spain's Civil war in 1936. Yet they all had the same ideal in mind, to fight against fascism. A progression with examples in the discipline of history can be created in a continuum of personal essays, letters, and memoirs writings about the Spanish Civil War from international participants. It could also be used in FL classrooms to link literary-cultural and historical content. As far as language learning, texts can be paired and translated into Spanish, scaffolding in the teaching of writing discussion texts based on the SFL-genre-based approach. (English Review, 4(1), 39-53) 
Timeline of SCW with an emphasis on the Abraham Lincoln Brigade adapted from Jefferson Hendricks and Cary Nelson ${ }^{5}$ :

1931

King Alfonso XII leaves Spain after Republican and socialist candidates are victorious in the nation's municipal elections.

$\underline{1935}$

1.Laurie Lee" memoir of pre-war Spain "As I Walked one Midsummer Morning"

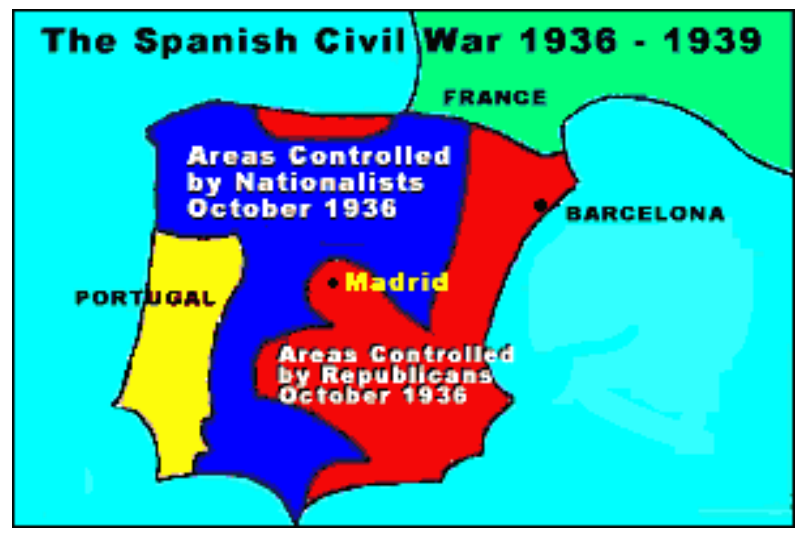

Figure 14: The Spanish Civil War 1936

\section{6}

July 17: Right-wing military uprising against the Spanish government is declared in Spanish Morocco

July 20: Insurgents defeated in Madrid; Republican government seeks aid from France; Insurgents appeal for help to Germany and Italy; Franco takes control of Insurgent armies

July 25: Hitler agrees to support Franco

July 26: German and Italian planes land in Morocco

August 8: France closes its border with Spain; unofficial "Non-Intervention" policy begins

August 14: Insurgents take Badajoz; over 4,000 massacred in the next ten days November 6: Republican government leaves Madrid and moves to Valencia; General Miaja named head of Madrid Defense Junta

2.Anna Starinov in "Behind Fascist Lines: A Firsthand Account of Guerrilla Warfare During the Spanish Revolution" 1936-37

${ }^{5}$ Cary Nelson and Jefferson Hendricks, eds. Madrid 1937: Letters of the Abraham Lincoln Brigade from the Spanish Civil War, copyright 1996 by Routledge. 
3.Mariano Garcia Bermúdez Memoir "Mi familia durante la Guerra Civil Española" 1936-37

November 8: International Brigades arrive in Madrid

November 18: Germany and Italy recognize Nationalist government

December 25: The first Americans leave New York harbor on the S. S. Normandie to fight for the Republic

1937

4. "A Moment of War" L. Lee's Memoir as a combatant in the Spanish Civil War from 1937-38

February 5-27: Battle of Jarama

February 16: Lincoln Battalion first moved to the front lines at Jarama; the first Lincoln casualty, Charles Edwards, on the 17th

February 27: Lincolns attack Pingarrón Hill ("Suicide Hill") in Jarama Valley; of the $\mathbf{5 0 0}$ who went over the top, more than $\mathbf{3 0 0}$ were killed or wounded

March-May: Americans form two new battalions--the George Washington Battalion and the MacKenzie-Papineau Battalion (consisting mostly of Canadians)

May 3-8: Fighting in Barcelona between CNT, FAI, POUM, and the PSUC and police

5. "Vision on Fire" (Letters) by Emma Goldman

April 26: Guernica bombed by German planes; over 2,500 civilian casualties

October 19: All of Northern Spain in Nationalist control

November 30: Republican government moves to Barcelona

1938

6.Malaga Burning: An American Woman's Eyewitness Account of the Spanish Civil War by Gamel Woolsey

April 15: Nationalists breakthrough Republican forces and reach Mediterranean at Vinaroz; Republican Spain split in two

May-July: Lincolns still in training on the east side of the Ebro, in Marsa; their number are increased to almost 700

August 15: Lincolns sent back to front, to Sierra Pandols southeast of Gandesa; the battalion strength is down to 300 , with fewer than 100 Americans; they are bombarded by artillery and aircraft for ten days, but hold Hill 666

September 21: Juan Négrin, Prime Minister of the Republic, announces to the League of Nations at Geneva a unilateral withdrawal of all international troops from the Republican army; the Lincolns are near the front lines just east of Corbera September 30: Munich Pact seals fate of Czechoslovakia, and of Spain's last chance for intervention; Neville Chamberlain declares "Peace in our time"

October 29: Farewell parade in Barcelona for the International Brigades

1939

January 26: Nationalists capture Barcelona; nearly 100 more Americans escape to France 
7. "Letters from Barcelona" by Lois Orr

February 27: France and Britain recognize Franco regime

March 27: Nationalists take over Madrid

April 1: Franco declares war ended; more than 90 Americans in Nationalist prisons, most to come home that month

September 1: Hitler invades Poland; World War II begins

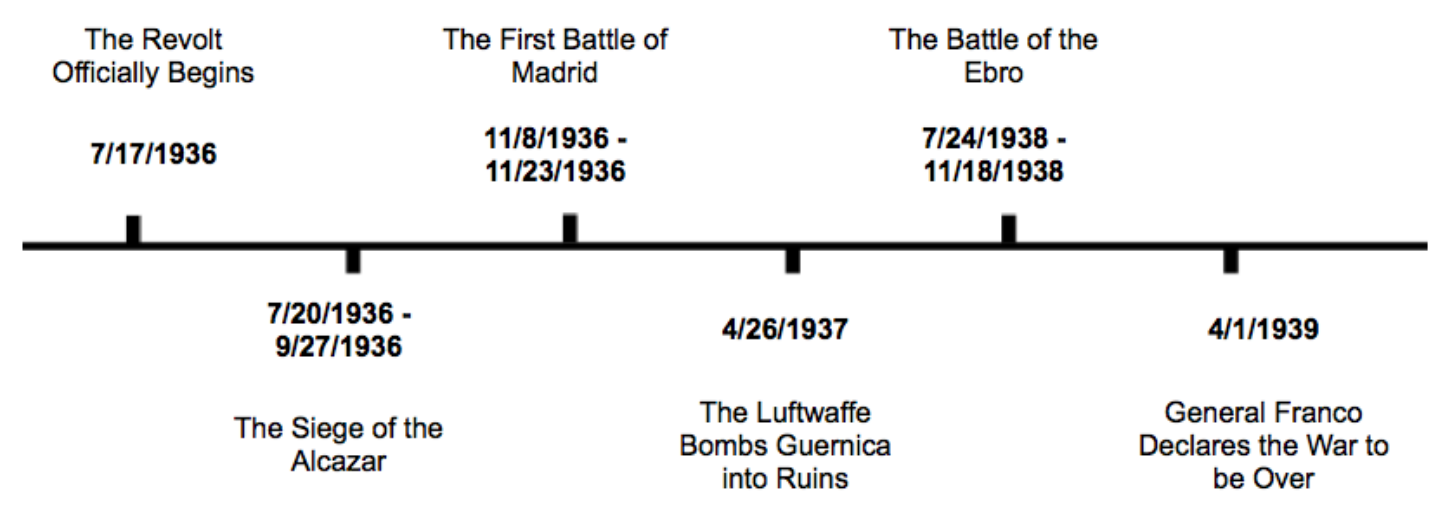

Table 3: SCW Timeline

Text Sequence Of SCW Events, Background And Recording Genres

1. English writer Laurie Lee's memoir of pre-war Spain "As I Walked one Midsummer Morning" is a good start in the line of events. There is a plethora of texts you can choose from his trip in 1935 to Spain to illustrate, assuming the FL teacher knows the culture well, the many misunderstandings he encounters given his total ignorance of Spain at that time. Yet a young Lee tries with the best intentions and interest, to understand a culture far removed from his own. In his account, the Spain of the 30 s, as in many other American historical books (especially before the Republic), is almost always described as an agrarian, large landowner, and medieval society. An assumed concept that did not reflect reality in its entirety. 
2. According to my father's memoir of the war (in Spanish), when Valencia became the Spanish capital city in November 1937, as the government fled the besieged Madrid for the relative safety of the port city, it was bombed repeatedly through the first half of 1937, especially the 28th of May, which held a whole new level of attack lasting around 30 minutes and 200 people were killed. Much of Valencia's port area was destroyed, hampering the Republicans' ability to receive supplies and bring in international volunteers. The family then decided to move to Benimamet, near Valencia, to flee from the bombings.

3. My family's personal historical memory and that of the Soviet interpreter in the communist guerrilla Anna Starinov overlapped at this particular place and time. Benimamet was precisely one of the areas the soviet party chose to establish a training base of construction techniques of bombs and guerrilla strategies. My father describes their stay in a bucolic way: games in the garden and baths in the irrigation pond, of course, he also writes about other traumatic incidents since they did not stop being part of a war, but little did they know that two streets down from their house there was an arsenal and that an operation had been established that did not contribute precisely to their security. It will be interesting for this aspect of the war (communist intervention) to be described with Anna and my father's accounts. How daily people's activities were happening door-to-door to war preparations.

4. Because of Lee's time spent in Spain and upbringing in England, he felt the need to participate in the SCW and fight the incipient fascism with the International Brigades. "A Moment of War" is Lee's account of his muddle-up experience (again) 
as a combatant in the Spanish Civil War from 1937-38 and an excellent introduction to the political context and the general feeling that led young people from around the world to participate in the Spanish Civil War.

\section{Argument Unfolding Sequence Organized In A Rhetoric Way}

The following works are isolated cases because most American women that were involved with the SCW, in one way or another, generally did not manifest a particular affiliation to a political faction within the republican government; instead, they felt that they were part of a broader design: the fight against fascism.

\section{Explaining genres}

5. Emma Goldman, writer and anarchist par excellence, shows us in her correspondence the objectives, positions, and projects of the anarchist parties during the war, while the testimony of Lois Orr's "Letters from Barcelona" describes the last days of the ultimate fate of the supporters of the POUM in Cataluña. What a perfect contraposition of texts between the hopes and the results of the "good fight." Emma Goldman wrote an enormous number of letters that are collected in the book Vision on Fire about anarchists in Spain. It is worth mentioning her reports on the new educational projects that the anarchists tried to implement in colonies for orphans and other children, such as the Mon Nou school in the Pyrenees.

6. The memoirs of Gamel Woolsey about her time in Malaga during the beginning of the war, described perfectly the plights of a civil war where whole families find themselves in opposite fronts. Some political circumstances force the inhabitants 
to make decisions, of which they are not sure, as in the case of the republican Catholic believer friend of Woolsey. At the same time, they have to hide a whole family in their house, because the father is of well-known conservative tendencies. His book describes these aspects of the Civil War, where division into two camps was not so clearly delineated.

7. The correspondence that Lois Orr had with friends and family, on the other hand, illustrates the anarchist faction of the $\mathrm{POUM}^{6}$ where she worked. Her letters also describe the persecution and arrests that she, her husband, and many other foreign anarchists suffered in June 1937 and their flight to France at the end of the war.

\section{Deduction, Evaluation And Conclusion Of The SCW}

\section{Arguing Genres}

i. What place did the SCW have in contemporary history? What better than Claude Bowers, the American ambassador to Spain, to narrate the events from before to the end of the war. His reports on the events that were being published in the American press, which he finds to be erroneous, demonstrated the manipulation of fascist propaganda and the non-intervention position of his government. His memoir documented his time in Spain as ambassador, describing his travels around the country and the restlessness in politics that presaged the SCW. He stood up for the Spanish Second Republic regime and was highly critical of what he saw as fascist agitation. Many terms or concepts in his memoir were unusual

\footnotetext{
${ }^{6}$ The Workers' Party of Marxist Unification
} 
to a Spaniard, for example, the Republican faction was also called the Loyalists' faction, i.e., loyal to a democracy chosen by the Spanish people that supported the established government of the Second Spanish Republic against the far-right Nationalist.

ii. A rich discussion-to-write can be created with a combination of these texts:

a. A Bowers' diary entry about the American press coverage of the war.

b. A pamphlet on the Roosevelt embargo on Spain.

c. The documentary by Hemingway and Joris Ivens, The Spanish Earth, showing an effort to change that policy.

The fact that the Russian government decided to intervene in the war was a definite handicap for the lifting of the embargo. The Spanish conflict began to be perceived as a communist threat and not as a struggle for democracy.

Personally, after reading the memoirs of the lives of some of the American women who were in Spain, especially those of Nurse Lini de Vries, I was able to find a more defined place for the SCW in contemporary history. It was a way to get closer and know this silenced part of Spain's history in a more personal way with direct testimonies and not with a list of facts, numbers, and percentages. Was the Spanish Civil War a lost chance to stop WWII? I firmly believe so.

The writer Josephine Herbst was the one who reflected best in her articles the profound idealism that led people from all over the world to participate in the SCW, when she 
finished watching the documentary Mourir in Madrid in 1966 she that night wrote to friends:

It came to me that in the most real sense my most vital life did indeed end in Spain. Nothing so vital, either in my personal life or in the life of the world has ever come again.

Table 4: GENRES ACROSS THE SPANISH CIVIL WAR

\begin{tabular}{|c|c|c|c|c|}
\hline $\begin{array}{l}\text { Text Type } \\
\underline{\text { Genre }}\end{array}$ & $\underline{\text { Structure }}$ & Language Aspects & $\underline{\text { Title }}$ & $\begin{array}{l}\text { Intention and } \\
\text { Strategy }\end{array}$ \\
\hline $\begin{array}{l}\text { Text Type: Short } \\
\text { Stories } \\
\text { Genre: } \\
\text {-Personal essays } \\
\text { narratives } \\
\text {-Memoir/s } \\
\text {-Diaries } \\
\text {-Letters } \\
\text {-Feature Articles } \\
\text {-Leaflets } \\
\text {-Film } \\
\text { Documentaries }\end{array}$ & $\begin{array}{l}\text { Structure: } \\
\text { Stages: } \\
\text { Orientation, } \\
\text { complication } \\
\text { and resolution } \\
\text { Phases: } \\
\text { Setting, } \\
\text { description, } \\
\text { episode, } \\
\text { problem, } \\
\text { solution, etc. }\end{array}$ & $\begin{array}{l}\text { Particular linguistic } \\
\text { aspects of short } \\
\text { stories. } \\
\text { Example: } \\
\text {-Expressions of } \\
\text { opinions } \\
\text {-Present perfect - } \\
\text { Narrative pasts - } \\
\text { Idiomatic } \\
\text { expressions } \\
\text {-Specific participants } \\
\text {-Time expressions - } \\
\text { Relative clauses } \\
\text {-Specialized } \\
\text { vocabulary } \\
\text {-The subjunctive - } \\
\text { Cohesive markers } \\
\text {-Evaluative } \\
\text { particles } \\
\text {-Rhetorical } \\
\text { questions } \\
\text {-Markers of } \\
\text { comparison contrast } \\
\text { and casualty - } \\
\text { Subordination and } \\
\text { clauses } \\
\text {-Open-ended } \\
\text { questions - } \\
\text { information } \\
\text { structuring }\end{array}$ & $\begin{array}{l}\text { "As I Walked one } \\
\text { Midsummer Morning" } 1935 \\
\text { "Malaga Burning" } 1936 \\
\text { "Behind Fascists Lines" } \\
\text { 1936-37 } \\
\text { "Letters from the Front" } \\
\text { 1936-39 } \\
\text { "Vision of Fire" } \\
\text { 1936-38 } \\
\text { "A Moment of War" 1937-38 } \\
\text { "Mi Familia durante la GCE" } \\
\text { 1936-39 } \\
\text { "My Mission to Spain" } \\
1936-39 \\
\text { "Up from the Cellar" } \\
1905-1962 \\
\text { "The Starched Blue Sky } \\
\text { of Spain" } \\
1920 \text {-1930s } \\
\text { "The Spanish Earth" } \\
1937\end{array}$ & $\begin{array}{l}\text { Specific } \\
\text { communicative } \\
\text { intentions within } \\
\text { personal essays } \\
\text { Strategy: } \\
\text { Direct experience. } \\
\text { Drawing } \\
\text { inferences. } \\
\text { Summarizing. }\end{array}$ \\
\hline
\end{tabular}




\subsection{The personal essay genre as the basis for developing writing tasks, introduction, themes and forms}

There are numerous connections between the memoir and the personal essay. Some of the "greatest works of autobiographical prose are personal essays: both Nabokov and McCarthy's books consist of strings of discrete personal essays that add up to a memoir, a formal innovation in itself." (Lopate,2013:207). During the 1970s and 1980s collegiate programs in the US, such as the Voice Project at Stanford University, "sought to renovate the teaching of freshman composition by emphasizing autobiographical writing...(vs.) freshman composition mainly as a way to hone argumentative skills and defend a position in an academic paper or debate." (Lopate, 2013:109)

In the early 80 s, I was a student in the writing department at the University of Delaware for a second language acquisition adult class. We had free access to one-to-one tuition with a graduate student to help with our essays. We progressed more in that weekly seminar class than in all ESL classes I had taken before. Later on, during my Master studies in Social Anthropology at UCL, most of our reading was in the essay form, and I discovered the personal essay genre ${ }^{7}$.

\footnotetext{
${ }^{7}$ A. Alvarez, Levi-Strauss
} 
Some Classic Practitioners: James Baldwin and Reinaldo Arenas

When Phillip Lopate teaches the literary texts of personal essays, he chooses Baldwin's work for motivating his students. They can relate to his honesty and passion about his "loss of faith, yearning to write, father's death, the foregoing of college, struggles over racial bitterness and sexual preference sympathizes with the efforts of all youth." (Lopate, 2013:179).

From "Notes from a Native Son," where Baldwin wrote about his father, students learn about not being intimidated of giving away too much personally on their essays:

Handsome, proud and ingrown, "like a toenail," somebody said.... he really should have been naked, with warpaint on and barbaric mementos, standing among spears. He could be chilling in the pulpit and indescribably cruel in his personal life and he was certainly the most bitter man I have ever met...When he took one of his children on his knee to play, the child always became fretful and began to cry;...I do not remember, in all those years, that one of his children were ever glad to see him come home... He had lived and died in an intolerable bitterness of spirit and it frightened me, as we drove him to the graveyard through these unquiet, ruined streets, to see how powerful and overflowing this bitterness could be and to realize that this bitterness now was mine." (Baldwin, 1955:29).

With this paragraph, P. Lopate tries to get his students to write a portrait of their father or mother, incorporating some characteristics they had passed on to them or prompt a piece about growing up. As Flannery O'Connor observed, anyone who has survived childhood has enough material to write for the rest of their lives, and in this case, to remember that "you own what happened to you" (Lamott:6), will result in students being especially involved in their work.

Before the Night Falls (2001ed.), a memoir by Cuban writer Reinaldo Arenas is an excellent example in Spanish along these lines of honesty. It describes his poverty- 
stricken childhood in rural Cuba, his adolescence as a rebel fighting for Fidel Castro, and his life in revolutionary Cuba as a gay man. His account as the Castro government suppressed his writing and persecuted him for his homosexuality until he was finally imprisoned, and final flight to the US can serve as a study within the PE genre for advanced levels:

Before getting to my mother's house, I would always think of her on the porch or even on the street, sweeping. She had a light way of sweeping, as if removing the dirt were not as important as moving the broom over the ground. Her way of sweeping was symbolic; so airy, so fragile, with a broom she tried to sweep away all the horrors, all the loneliness, all the misery that had accompanied her all her life..." (Arenas, 2001ed:136).

\section{Language Memoirs, a Mandatory Genre for SLA}

American writer Alice Kaplan's memoir about her experience learning and teaching French helped my students better understand their immersion abroad. In her writings, she articulates with precision the vicissitudes of learning a second language in Europe. Before my class on different uses of Spanish past tenses, students read a passage explaining how she learned and later taught the same tenses they were learning (same in French and Spanish):

The difference between the passe compose, and the imparfait is something every French teacher learns to teach, one of the standard rites of the pedagogy. You learn to draw a timeline. You go up to the blackboard, and it's dramatic, and you say, "this is the imperfect: the imperfect is for description; it's for events that haven't finished." The time it takes to say this is just about the time it takes to drag your chalk line, slowly, all the way across the board. You pick up your chalk and you explain, chalk in hand, that the imperfect is used to describe feelings, states of being; it's used to describe background, landscape, and ongoing thoughts. All sorts of things with no definite beginning and end. Then you pause, take hold of your chalk piece like a weapon, and you stab that blackboard line at one point, then at another. This is the passe 
compose, this staccato: a point on the imperfect line of experience, a discrete action in the past with a beginning and an end that you can name." (Kaplan, 2009:142).

Initially, I thought the reading exercise bombed, they took turns reading this one-page passage, and there was a prolonged silence afterward (or so it seemed to me, a Harkness beginner). When they came back to class from the weekend, they've had many thoughts and opinions about it. We discussed how they felt about grammar for more than 30 minutes. It helped the class to understand the lack of grammar education during their school years.

We were inadvertently executing what Kaplan describes as "talking cures: like analysts, language teachers are always in search of the foolproof method that will work for any living language and will make people perfectly at home in their acquired tongue." (Kaplan:1220)

\section{The Personal Essay, "A Unity of Human Experience."}

What defines a personal essay? According to P. Lopate, a PE authority:

The PE is not a legal brief, nor an argument, but an exploration... Plato attacked the teachers of rhetoric for wanting to win an argument more than uncover moral truth...Still, who was more adept at maintaining an argument than Plato? I am coming to think that all good essays are dialogues, and all take of both exploration and argumentation...It is my underlying conviction that nonfiction as a practice tends toward reason, calm, insight, order." (Lopate, 2013:109-11). 
Because of its nature, it is not easy to arrange well-defined categories for the PE:

\section{Different "types" of creative non- fiction writing:}

Due to the fact that creative nonfiction is an ever-evolving genre of writing, it is difficult to define set types:

- The Personal Essay:

A piece of writing, usually in the first person, that focuses on a topic through the lens of the personal experience of the narrator. It can be narrative or non-narrative-it can tell a story in a traditional way or improvise a new way for doing so. Ultimately, it should always be based on true, personal experience.

- The Memoir:

A memoir is a longer piece of creative nonfiction that delves deep into a writer's personal experience. It typically uses multiple scenes/stories as a way of examining a writer's life (or an important moment in a writer's life). It is usually, but not necessarily, narrative.

- The Short Short:

A short/short is a (typically) narrative work that is concise and to the point. It uses imagery and details to relay the meaning, or the main idea of the piece. Typically it's only one or two scenes, and is like a flash of a

moment that tells a whole story.

Table $5^{8}$

The PE belongs to the category of stories, highly valued in English-speaking countries, and can be classified into four-story genres: recount, narrative, exemplum, and observation with a unique schematic structure for each. The recount and observation genres are "reassuring" to represent journeys along a familiar path to the reader. Narrative and exemplum, on the other hand, are disruptive in nature and can present a crisis or complication that needs to be overcome (Rothery and Stenglin:1997). An autobiographical recount is a genre that one finds in private, familiar settings, focusing on themes associated with personal and immediate experiences.

Finding the connection between a genre, situation, and topic will enable students to learn the language abilities, the literary genre, and culture at the same time.

\footnotetext{
${ }^{8}$ Verity Davidson
} 
Phillip Lopate recounts:

As I go about my daily life, I'm turning it into a story... A psychotherapist might find drawbacks to this method: by turning my life so quickly into a story, I fail to live in the moment...When I write about an experience, what I try to do is to correct the sins of the ego by analyzing what happened, dissecting my own motives, and putting myself in the other person's shoes...Often, what will start me on the hunt for a story (or an explanation...) is an unresolved moment, a mysterious gesture or comment that nags at me. (Lopate, 2013:96-97).

One common characteristic of the personal essay genre is an obligatory opening stage that establishes the context and an interpersonal meaning indication both necessary to make the story entertaining. In this outline the simple narrative obligatory moves inspired me:

\section{Set the scene}

a. Include a hook of some sort to pull readers into your narrative.

b. Set the scene for your story. Avoid giving too many details, as you want your audience to keep reading.

\section{Describe the problem or event}

a. Provide baseline information for your narrative, give details about the other characters in your story, or describe the feelings you were having while the events were happening.

\section{Go into detail}

a. Help the reader connect with your narrative by describing the events and providing details about what was happening and how you were feeling.

\section{Talk about what you learned}

a. Share what you got from the experience, how it helped you, or why it was significant. $^{9}$

\footnotetext{
9 Wikihow community
} 
Linguistically, obligatory moves are also differentiated by being additive or temporal, or in transitivity patterns to express what the experience meant.

Thus, the suitability of a topic must be determined by the type of language that is likely predominant in texts that deliver the content.

For the personal essay genre, the curriculum should include recounting, reporting, and narratives or stories that focus on the corresponding representation of everyday experiences in the verbal system and involve "natural" Participants, Processes, and Circumstances. This starting point could be extended in later levels to the public sphere and conclude at the uppermost levels with academic and professional genres.

This process of modeling and joint negotiation of a genre's significant features that occurs between instructor and student culminates in an independent production of the genre by the learner who, hopefully, can then appropriate the language acquired and assert their individuality. These same features serve as well as clear criteria for the instructor to provide feedback.

\section{PE Features}

The hallmark of the personal essay is its intimacy. The writer seems to be speaking directly to your ear, confiding everything from gossip to wisdom. Through sharing thoughts, memories and desires, complaints...the personal essayist sets up a relationship with the reader, a dialogue, a friendship if you will, based on identification, understanding...and companionship. At the core of the personal essay is the supposition that there is a certain unity to human experience." (Lopate,1995: XXIII)

According to P. Lopate to create nonfiction there are some qualities that writers need to foster, what follows is a summary of his exceptional PE study based on more than forty years of lessons from his career as a writer, and professor of creative writing: 
-Curiosity: the combination of research-driven by curiosity and a personal interpretation is a formula that succeeds in all types of nonfiction such as travel and nature writing, family histories, or political investigations.

-Imagination with a plot: Many students can engage with their reality more confidently with personal essays than in an imagined piece, and yet they soon realized they have to cultivate as much imagination to create a meaningful structure in a context as in a fictional narration.

-Truth: Searching for the truth is one of the characteristics of nonfiction writing. For that purpose, the courage to be honest, not only about what happens in the world but also about how it affects us (feelings, doubts), is essential.

For Ann Lamott, "good writing is about telling the truth. We are a species that needs and wants to understand who we are." (Bird by Bird:3)

-Imagination and Facts: Facts are a necessary tool to describe our limits and destinies: "One is born and raised in New York City, ... or Calcutta, and from that simple fact, all sorts of consequences follow. One grows up Mormon, Communist..., raised by one or two parents..." (Lopate, 2013:80). However, finding a pattern in our experience that has a meaning and character it's more difficult than in a fictionalized narrative.

-Underlying connections between experience and memory: In the process of creating a personal story, a writer might come upon a new meaning of life that derives from the distinctive shape of reality. 
In her classic book about writing, Ann Lamott explains this important PE characteristic further: "Let the Polaroid develop; in other words, observe, watch, listen, stay in the moment, until you understand what you want to write about. As the portrait comes into focus, you begin to notice all the props surrounding these people, and you begin to understand how props define us and comfort us, and show us what we value and what we need, and who we think we are". (Lamott, 2007:40). For many PE writers, the nature of most good writing lies in finding out things as you go along, similar to when some sculptors feel the shape dormant underneath the material of their choice.

Ultimately PE writers should aim to write in their own voice; it does not matter if you are a hundred percent accurate about the facts as long as you transmit your/the truth successfully, already powerful by itself.

The greatest writers of PE reach the perfect so-called hypnotic state that readers experienced, in which nonfiction reads like fiction.

\section{PE Forms}

In SLA modeling a text helps learners to stretch their own syntactic knowledge. It is similar to copying a painter's strokes. By imitating them, you learn about shading, light, and color, which can then be incorporated into your free expression.

Personal essays can be written in these various forms: Analytic Meditations, Book Reviews, Consolation, Diary/Journal Entry, Diatribe, Humor, List, Lecture, Letters (Epistolary essay), Mosaic, Memoirs, Newspaper Column, Portrait, and Double Portrait, Prose Poem and Reverie, Reportage, Valediction. 


\section{$\underline{\text { PE Forms particularly useful for FL teaching and learning }}$}

\section{Travel writing, Journals, Notebooks}

As American essayist E. Hoagland noted, travel inspired him to find common features of people in all places, a concept that should be incorporated in any journal FL assignment along with the differences that students effortlessly pick up.

Writer's notebooks, on the other hand, have been compared to "a laboratory, a mirror, a brainstorming tool, an icebreaker... a junk drawer, a confessional, a postcard to oneself, a singing in the shower, a jump-start cable, ...an archive, an anthology, a warehouse... a snooping device... a survival kit, way of documenting mental illness, a meditation practice... a therapist, a spiritual adviser, a punching bag, a sounding board, a friend." (Lopate, 2013:100-01).

I found journals to be particularly useful as writing icebreakers at the beginning of a semester. Diaries fitted well with their limited knowledge of grammar as a first exercise of the written curriculum. Since I assigned them for a specific trip, they all went, students tended to write things down quickly without overthinking about linguistic forms and without censoring themselves.

It was important to balance the research and documentation of the trip with their individual reactions and feelings about it. Research on the countries they were traveling always helped form the initial concept or idea that sparked their imagination about their adventures.

Besides, when students invested time in researching, it was easier to put their own twist on a subject and more likely to motivate them to own and finish a writing project. 
Unlike personal essays, journals are more relaxed because the writer is not obliged to make sense of it but just reporting to the best of your abilities, yet both depend on unrolling thought processes.

\section{The I-character in The Personal Essay}

In any autobiographical narrative, whether memoir or personal essay, the marrow often shows itself in those moments where the writer analyzes the meaning of his or her experience.(my emphasis, (Lopate, 2013:26)

If the art of characterization entails creating "a pattern of habits and actions for the person you are writing about and introducing variations into the system" (Lopate, 2013:18) then when the main character is yourself, and you try to describe the characteristics that set you apart, it is crucial to gain some distance and rise above yourself so that you can present it as an all-round character.

Also, characters that tend to be more attractive to the reader are those who do not shy away from their inevitable imperfections: "When people shine a little light on their monster, we find out how similar most of our monsters are." (Lamott, 2007:198).

Writing about one's childhood is a task that any student can attempt since anybody's childhood has a vast array of experiences to write about, many deeply felt, some of them so ingrained in our memory, because it was a time when we were intensely aware of the world and when our powers of observation were at their sharpest, unpolluted by later preconceptions. This effort to understand it "will give you the ability to empathize, and that understanding and empathy will teach you to write with intelligence, insight, and compassion." (Lamott, 2007:225).

For Phillip Lopate as ethnicity, gender, religion, social class, geography, and political affiliation define us, so are the challenges we have encountered along the way. 
He continues: "There are hard choices to be made when a person is put under pressure, and it is in having made the wrong choice, curiously enough, that we are more aware of our free will and humanity. (Lopate, 2013: 24-5).

Conflict in a personal essay is necessary. It might be a difficult problem encountered, and, as I mentioned before, it needs to be exposed with honesty.

The writer Alice Adams suggests a formula when writing a short story that can also be applied to developing a personal essay story that includes conflict.

It goes ABDCE, for Action, Background, Development, Climax, and Ending:

You begin with action that is compelling enough to draw us in, make us want to know more. Background is where you let us see and know who these people are, how they've come to be together, what was going on before the opening of the story. Then you develop these people, so that we learn what they care most about. The plot-the drama, the actions, the tension-will grow out of that. You move them along until everything comes together in the climax, after which things are different for the main characters, different in some real way. And then there is the ending: what is our sense of who these people are now, what are they left with, what happened, and what did it mean?" (Lamott, 2007:62).

In the case of the PE, the observer, ourselves, can also participate in the action, which can be quite freeing.

The following are some useful tricks of the trade that I have collected from my readings about the PE genre for teachers and learners alike:

-To combat self-doubt, think yourself as the writer of your age.

-To amuse the reader, you must amuse yourself first.

-Invite the "most far-fetched, mischievous notions...they may point to an element of truth that would otherwise be inaccessible." (Lopate,2013:24).

-To end an essay, you may use: “...an image, an epigram, a line of dialogue, a joke, a question, a quote, an ellipsis, in short as many literary techniques as exist... 
One way to end an essay is to introduce a new insight that has been either held in reserve just for that occasion or stumbled upon in concluding. Something fresh, in any case... An essay may end in a sight, a shrug, a sudden mood change." (Lopate,2013:58-9).

From certainty to doubt, "solo se que no se nada"10 (Socrates) is a fitting ending too. Many students like to end their essays following the classic structure of essays with a meaningful conclusion, but some issues such as family strained relationships might be impossible to solve.

The most talented writers ${ }^{11}$ end their essays with two clashing ideas held suspended in the mind: "The test of a first-rate intelligence is the ability to hold two opposed ideas in the mind at the same time, and still retain the ability to function." (Fitzgerald, 1945:69)

\section{PE Themes}

There are as many themes for personal essays as lives lived: Ambition, City Life, Country Living, Death, Disability and IIIness, Drugs and Alcohol, Education, Family Ties, Food, Friendship, Growing Up, Habitations, Hatred and Opposition, Leisure and Idleness, Love and Sexuality, Marriage, Music and Art, Nature, Perception, Politics, Race and Ethnicity, Reading and Writing, Solitude, Theater, Film and Other Spectacles, Thresholds, Walking.

\footnotetext{
${ }^{10}$ Plato's account of the Greek philosopher Socrates.

11 e.g. "Notes of a Native Son," by James Baldwin
} 
Table 6: Personal essays especially suited themes and prompts for FL teaching and learning

\begin{tabular}{|c|c|}
\hline Themes & Prompts \\
\hline $\begin{array}{l}\text { Initiation: } \\
\text { We find ourselves growing up in a grown-up world }\end{array}$ & "One way or another, we all grow up." (Hunt:19) \\
\hline $\begin{array}{l}\text { Femininity and Masculinity: } \\
\text { We find ourselves confronting a fork in the road. }\end{array}$ & $\begin{array}{l}\text { "Even in our time, when the roles of men and women } \\
\text { are defined with a flexibility that would have astonished } \\
\text { our ancestors, sexual identity provides one of the great } \\
\text { forks in the road of everyone's life." (Hunt:119) }\end{array}$ \\
\hline $\begin{array}{l}\text { Insiders and Outsiders: } \\
\text { We find ourselves dislodged and excluded. }\end{array}$ & $\begin{array}{l}\text { "...problems created by our inability to spread love, } \\
\text { admiration, or even respect, evenly in society.... Simply } \\
\text { because of being human, most of us have stories to tell } \\
\text { about being outsiders struggling for acceptance, or } \\
\text { insiders trying to maintain our position." (Hunt:277) }\end{array}$ \\
\hline $\begin{array}{l}\text { Nature and Civilization: } \\
\text { We find ourselves among the beasts. }\end{array}$ & $\begin{array}{l}\text { "From a variety of perspectives essays would offer } \\
\text { intense observation of creatures, both human and } \\
\text { nonhuman, and insight into their interactions with one } \\
\text { another." (Hunt:353) }\end{array}$ \\
\hline $\begin{array}{l}\text { Media: } \\
\text { We find ourselves in a hall of mirrors. }\end{array}$ & $\begin{array}{l}\text { "...consider the meaning and the effect of centuries-long } \\
\text { shifts from "natural" reality to the reality of the media." } \\
\text { (Hunt:509) }\end{array}$ \\
\hline $\begin{array}{l}\text { Understanding: } \\
\text { We find ourselves in our findings. }\end{array}$ & $\begin{array}{l}\text { "...facts are merely the building blocks of understanding, } \\
\text { worth very little unless we know how to think about and } \\
\text { interpret them, how to use them, and how not to use } \\
\text { them...exploring our means of making sense of the } \\
\text { world, and finding ourselves in our findings. (Hunt:599) }\end{array}$ \\
\hline
\end{tabular}

\section{The Contrarian Essay for Advanced Levels of Language Learning}

...the contrarian essay is an exercise in inside-out thinking. (Lopate, 2013:66).

One of the advantages in presenting yourself from the beginning as an eccentric person

like $\mathrm{O}$. Wilde is that "not only gives the reader a space to entertain forbidden or antisocial thoughts with minimal risk" (Lopate, 2013:70-1) but it can also lead to students finding their own "voice" (or writing style). 
He certainly was a master in provoking while concealing his insults with humor and wit: "Some cause happiness wherever they go; others whenever they go." (Oscar Wilde, retrieved from: https://www.goodreads.com/quotes/1347349-some-cause-happinesswherever-they-go-others-whenever-they-go).

In short quality essays are full of doubt, self-doubt, and ambivalence, sometimes resulting in the reader's strengthened own convictions. This type can also be a sort of "thinking against one-self" exercise or "a resistance to conventional truths." (Lopate, 2013:65-69) 
Table 7: PE Features, Themes and Forms

\begin{tabular}{|c|c|c|}
\hline \multicolumn{3}{|c|}{ PERSONAL ESSAY } \\
\hline FEATURES & THEMES & FORMS \\
\hline $\begin{array}{l}\text {-Curiosity-driven research. } \\
\text {-Imagination: recounting, reporting, and } \\
\text { narratives or story genres. } \\
\text {-Pursuit of truth. } \\
\text {-Underlying connections between } \\
\text { experience and memory. } \\
\text {-Powerful and strong own voice. }\end{array}$ & $\begin{array}{l}\text {-Initiation } \\
\text {-Femininity } \\
\text { and Masculinity } \\
\text {-Insiders and Outsiders } \\
\text {-Nature and Civilization } \\
\text {-Media Mirrors } \\
\text {-Understanding ourselves } \\
\text {-The Contrarian Essay Inside- } \\
\text { Out thinking }\end{array}$ & $\begin{array}{l}\text {-Travel writing, Journals, } \\
\text { Notebooks } \\
\text {-Analytic Meditations } \\
\text {-Diatribe } \\
\text {-Humor } \\
\text {-Letters (Epistolary essay) } \\
\text {-Mosaic } \\
\text {-Memoirs } \\
\text {-Newspaper Column } \\
\text {-Portrait and Double } \\
\text { Portrait } \\
\text {-Prose Poem and Reverie } \\
\text {-Reportage } \\
\text {-Valediction. }\end{array}$ \\
\hline
\end{tabular}




\subsection{Translating Insights about the Personal Essay Genre into Genre-Based Writing Tasks}

Prestigious essayist A. Lamott in her book about writing Bird by Bird gives some practical and valuable advice for all personal essay practitioners:

-Write regularly, whether you feel like writing or not, and whether you think what you are writing is any good.

-Give yourself short assignments, so you do not get overwhelmed.

-Do not expect a piece of writing to flow perfectly out of your fingers on the first go:

If you find that you start a number of stories or pieces that you don't ever bother finishing...it may be that there is nothing at their center about which you care passionately. You need to put yourself at their center, you and what you believe to be true or right. (Lamott, 2007:103).

Personal essay writers, especially in a second language, would find her final advice about self-doubt and confidence useful: face the white page with courage so you can attempt to block the interior station that feeds doubt and criticism into your brain.

\section{Writing with Meaning-Making Texts}

In discussions of task-based syllabi, a task is defined as an activity in which meaning is primary; there is a goal that must be attained, and the activity is outcome-evaluated. (Skehan, 1998)

Through a range of pedagogic tasks, students can gradually link the target forms to the context they have used. Tasks contain several phases of classroom work that highlight 
what teachers and learners do during task-based teaching: (1) task input, (2) pedagogic task, (3) target task, and (4) task follow-up. (Norris, 2009):

1-According to Norris, a task input phase introduces the target task as it is realized in actual communication. In the context of a writing classroom, examining samples is one technique that enables the presentation of a target task. Engaging receptively with these tasks enables learners to "begin to focus their attention on trying to understand what is said or written, thereby initiating their noticing of what forms are used in what ways". (Norris, 2009:583).

2-During the pedagogic task phase, tasks are segmented and elaborated to enable learners to raise their awareness of new forms and their use of particular functions. Therefore, the pedagogic task phase emphasizes form-function relationships through learner analysis of discoursal, textual, rhetorical, and linguistic features of texts. Feedback (e.g., presentation of models and explicit grammatical explanations) and teacher scaffolding also play crucial roles during this phase to foster learners' awareness of target language forms.

3-The target task encourages learners to demonstrate what they have learned through multiple iterations of pedagogic tasks that involve actually performing it.

4-The task follow-up phase encourages learners to reflect on the material they have learned previously, performance strengths and weaknesses, and perceived difficulty, all of which led to "instructional decisions regarding what features are in need of subsequent repetition or expansion". (Norris, 2009:585). 
Not every cultural content feature that learners should know or be aware of is suitable for language learning at a particular stage. It is the quality of the curricular decision and pedagogical realizations that make texts come alive for the content-language link. Text selection can change, but principles guiding it are constructive in educational practice.

The majority of texts that represent the level concerned in this study are from primary discourses characterized by informal communications between intimates on topics of common and shared knowledge, such as personal information, food, housing, travel, personal recounts, and accounts.

In the gradual construct of genre, the stages envisioned in the curriculum, and the pedagogical actions for their realizations coexist. Genres themselves can be arrayed in ways that can be translated into curricular contexts, texts, and tasks that derived from them. In their study Byrnes, Crane, Maxim, and Sprang (2006) highlighted the advantages of linking tasks with texts in terms of genres. They proposed constructing a multi-year trajectory by spelling out the kinds of textual abilities linked to language that instruction would target in their curricular and pedagogical actions with texts, and to know how an assessment of learning outcomes would be possible at the end of a semester or level. (Byrnes, 2002b)

The discourse contexts of tasks that involve sequencing, statement of opinion, explanations, or making recommendations pushes learners towards the exploration of complex sentences with various forms of subordination. For example, in my class, the communicative context of chronological discourse was taught by lexical items (in a diary), such as discourse markers first, then, and at last (my example). Later the students explored more sentence-integrated ways of indicating sequencing, through the use of 
dependent clauses of time, with such conjunctions as when, after, and before. In the case of St. Anselm College, students described their progression from general Chinese horoscope predictions to their own intentions and decisions for the future.

Genre exemplifies the connection between language and content. By its very nature, genre requires the use of specific language features to realize its communicative purpose. Grammar is, thus, not seen as an end unto itself but rather as a resource for expressing specific content, only possible with the assistance of specific language forms. By identifying the essential and obligatory properties of a genre, we can also establish the requirements for a successful task completion. The patterns and regularities of genre, one deconstructed and identified, become the core of the class pedagogy so that students can ultimately reproduce genres independently. At the same time, genre-based tasks offer a valuable and authentic way to examine and analyze how language operates in the target context. 


\section{Methodology}

\subsection{Participants}

There was something in the Spring 2016 class that was different from others. Certainly, the small number of students (14) always helps in language learning and instruction. In addition, students were assessed for language placement for the first time in the Valencia Florida State University abroad program. But most of all, there was a willingness to give up their egos and to share their knowledge. I found real joy as the class moved forward, and they were at ease to ask questions. At times we all suffered from a couple of disengaged students that came from a different university and another especially unprepared and disinterested student that was actually put in place by the others. As long as they are in the minority, they should not have the power to flatten the whole class.

In FSU, one cannot assume high levels of student literacy even in their L1 and especially not in their L2. Most of the students have not had experiences with learning other languages. A few did in high school. Usually, that instruction placed little emphasis on writing development and did not link content to language. It is essential to attract students at these early stages of instruction, so hopefully, they progress to higher Spanish levels. Students were not geared for the School of Foreign Service.

The final results in prototypical end tasks were compared with the final essay tasks of a traditional instructed Spanish class of the same level.

In the 2019 winter and spring term, I had the opportunity to teach at Phillips Exeter Academy ${ }^{12}$, the birthplace of The Harkness method of learning and teaching, to three

\footnotetext{
${ }^{12}$ Exeter, NH, USA
} 
sections of Spanish level II. I have also included and compared their prototypical end tasks as it exemplifies an ideal set of circumstances: 13 or 14 students maximum, from around the world seated at a Harkness table eager to learn.

The essays from the most advanced level small class of the Spanish language at Saint Anselm College ${ }^{13}$ illustrate how far you can advance a language student's writing and learning proficiency following this instructed method.

I hope that the extent and range of all participants will give an accurate perspective of the beginning and middle level of Spanish language learning possible advanced abilities that would encourage further progress at the highest levels.

\footnotetext{
${ }^{13}$ Annex 6.3 and 9.3, Manchester, NH, USA
} 
Table 8: PARTICIPANTS

\begin{tabular}{|c|c|c|c|c|c|c|c|c|}
\hline $\begin{array}{l}\text { College or } \\
\text { School }\end{array}$ & $\begin{array}{l}\text { Instructed } \\
\text { Writing }\end{array}$ & $\begin{array}{l}\text { Non- } \\
\text { Instructed } \\
\text { Writing }\end{array}$ & Women & Men & $\begin{array}{l}1 \mathrm{st} \\
\mathrm{yr} .\end{array}$ & $\begin{array}{l}\text { 2nd } \\
\text { yr. }\end{array}$ & $\begin{array}{l}3 r d \\
y r .\end{array}$ & $\begin{array}{l}\text { 4th } \\
\text { yr. }\end{array}$ \\
\hline Spanish & Level II & & & & & & & \\
\hline $\begin{array}{l}\text { Florida State } \\
\text { University } \\
\text { Abroad } \\
\text { Program } \\
\text { Spring Class } \\
2016\end{array}$ & 14 & 9 & $\begin{array}{l}\text { IW } 9 \\
\text { N-IW } 8\end{array}$ & $\begin{array}{l}5 \\
1\end{array}$ & 8 & 0 & 2 & 4 \\
\hline Spanish & Level IV-V & & & & & & & \\
\hline $\begin{array}{l}\text { Saint Anselm } \\
\text { College } \\
\text { Fall } 2018\end{array}$ & 15 & 0 & 6 & 9 & 1 & 6 & 6 & 2 \\
\hline Spanish & Level I & & & & & & & \\
\hline $\begin{array}{l}\text { Phillips Exeter } \\
\text { Academy } \\
\text { Winter } 2019\end{array}$ & 12 & 0 & 5 & 7 & 10 & 1 & 1 & \\
\hline Total & 41 & 9 & & & & & & \\
\hline
\end{tabular}




\subsection{Description of curricular scope and sequence}

Designing the curricular scope and sequence to answer research question 1: How do college-level American FL writers develop their genre awareness, linguistic knowledge, and writing competence in a systematically designed genre-based writing course that incorporates personal essays/non-fiction writing tasks?

Text Linguistics has a crucial role in literacy since it concentrates on both the production and analysis of texts in a given language. (Martinez, 2006:139)

Answering question 1.1 How students produce syntax within the writing tasks assigned. What to teach and in what order is essential to assure that the language path is appropriate for that particular level for effective writing. Traditionally a grammatical syllabus served as the central principle for sequencing the curriculum; that is, the present tense was introduced before the past tense. However, as soon as language learning is developed through meaning-making, only grammar knowledge can no longer serve as the curriculum's organizing principle. Thus, knowing a language is conceived in terms of Halliday's concept of meaning potential rather than grammatical proficiency.

In this Level II course, students develop fundamental knowledge about the Spanishspeaking world and introduce them to cultural notions of time and space in such topics as talking about oneself and others, referring to activities and events (the present, past and future storytelling), occupations and pastimes, and the world around us. 


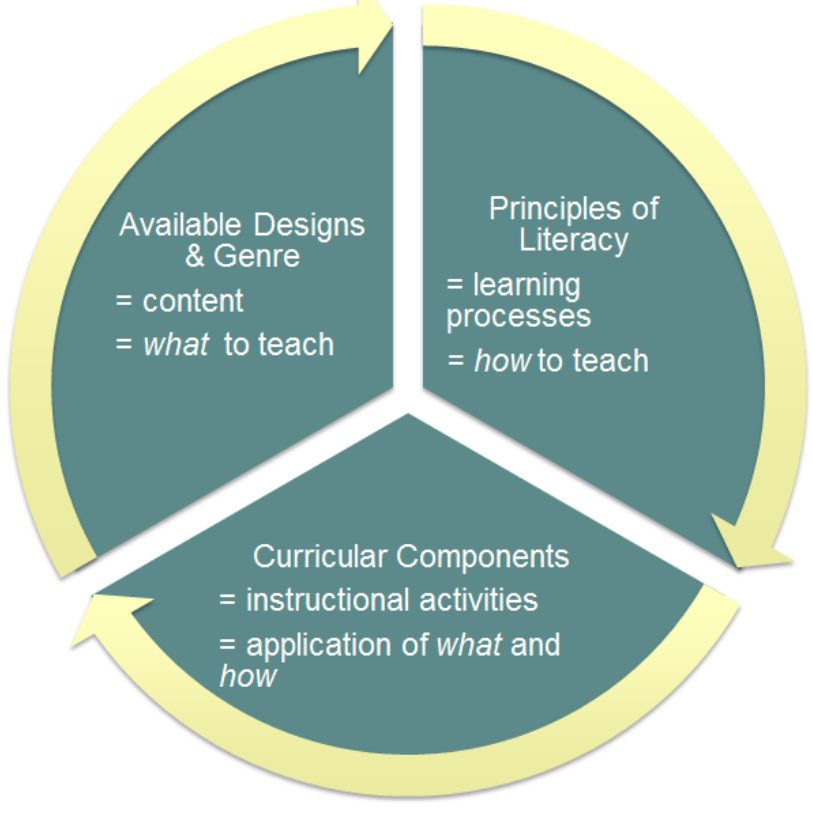

Figure 15: The New London Group (1996), Kern (2000)

At this stage, experiential writing dominated the semester. Students wrote about the given world around family, friends, and school in several modes, such as narratives in personal essays, journals, and letters. One of the reasons the compositions were mostly based on personal experience, which they know better than anyone, was to develop self-confidence as authors, critical in SLA since their ability to speak was limited.

A sense of authorship develops more effectively when the writer has leverage on the reader. In later semesters students can begin to reach beyond personal experience and explore other people's worlds and interests.

Oral and written narratives are central to achieving the stated curricular goal of language and content acquisition towards advanced literacy levels with various ways of reaching towards comprehending and producing their first coherent texts. Particular importance was given to sentence forming requirements, and for that reason, instruction aimed to model short practical texts in various contexts. 
One form of narrativity became original in this course, the personal story that relies on chronological ordering. It means that aspects of this discourse will be modeled, analyzed, and practiced along with the curriculum. Later on, this personal point of view can be extended to the public sphere:

Individual events are put in larger contexts, through comparison and contrast, cause and effect, the presentation of alternative proposals, and making decisions based on real or imaginary choices. Also, the simple narrative of consecutive chronology is expanded and made more complex, different positions of author and actor and perspectives. (Byrnes, 2001:86).

In the classroom, I followed Kaplan's first four stages of writing and Rothery's pedagogy:

- Setting the context: explaining the genre and its use. Prewriting

- Modeling: analyzing a text created explicitly for that task. Prewriting

- Joint construction: students are guided in writing the text together as a class activity. Drafting

- Independent construction: students write alone with the teacher as a facilitator and evaluator. Drafting and Revising

- Several drafts were written to improve and achieve the set goals. Revising/Editing

- Comparing and linking: sharing similar and different features among different resulting texts from students. Revising

This chapter aims to develop a curricular level and associated learning outcomes to mark stages in writing development. Following the GUGD ${ }^{14}$ study, each level will be described in terms of a profile that establishes tasks, content and language areas that writers can work with, and the type of performance one can expect of them on the path toward advanced abilities. Equally important are texts needed to represent the language features targeted for each curricular level.

\footnotetext{
${ }^{14}$ Georgetown University German Department, 2011
} 
The following is a good example ${ }^{15}$ of a literary focused French class that incorporates primary and secondary genres with linguistic functions:

Allen \& Paesani

Feasibility of a Pedagogy of M(ulaliteracies

\section{Appendix}

Model Design of an Introdnctory-Level (Second Semester) Literacy-Based French Cucriculum

\begin{tabular}{|c|c|c|c|c|c|}
\hline & $\begin{array}{l}\text { Textbook } \\
\text { Units }\end{array}$ & $\begin{array}{l}\text { From market to } \\
\text { sable }\end{array}$ & Osc boste & $\begin{array}{l}\text { Personal } \\
\text { relatrionsbios }\end{array}$ & $\begin{array}{l}\text { Activities for all } \\
\text { seasons }\end{array}$ \\
\hline \multirow{3}{*}{ 桌 } & $\begin{array}{l}\text { Primary } \\
\text { Genreb }\end{array}$ & $\begin{array}{l}\text { "Le pacuet de } \\
\text { gateaux du } \\
\text { dimanche matin" }\end{array}$ & $\begin{array}{l}\text { "Le dimanche } \\
\text { soir" }\end{array}$ & $\begin{array}{l}\text { "Invitée par } \\
\text { surprise" }\end{array}$ & $\begin{array}{l}\text { "L.a bicyelette } \\
\text { et le vélo" }\end{array}$ \\
\hline & $\begin{array}{l}\text { Secondary } \\
\text { Genres }\end{array}$ & $\begin{array}{l}\text { - Images } \\
\text { (pastries) } \\
\text {-Advertisement } \\
\text { (Prench pastry } \\
\text { shop) }\end{array}$ & $\begin{array}{l}\text { - Artwork ("Le } \\
\text { dimanche," } \\
\text { Chagal; "Un } \\
\text { dimanche } \\
\text { après-midi," } \\
\text { Seurat) } \\
\text { - Song } \\
\text { ("L'escalier", P. } \\
\text { Piche) }\end{array}$ & $\begin{array}{l}\text { - Cultural } \\
\text { reading ("La } \\
\text { maison," } \\
\text { Carroll, 1991) } \\
\text { - Music video } \\
\text { ("Le diner," } \\
\text { Bénabar) }\end{array}$ & $\begin{array}{l}\text { - Website } \\
\text { (www: } \\
\text { jeprofitedelavie } \\
\text { avelo.com) } \\
\text { - Images } \\
\text { (casual vs. } \\
\text { competitive } \\
\text { cycling \& } \\
\text { cyclists) }\end{array}$ \\
\hline & $\begin{array}{l}\text { Linguistic } \\
\text { Punctions }\end{array}$ & $\begin{array}{l}\text { - Ordering / } \\
\text { talking about } \\
\text { mexls / dishes } \\
\text { - Describing past } \\
\text { events }\end{array}$ & $\begin{array}{l}\text { - Describing } \\
\text { your home } \\
\text { - Making } \\
\text { suggestions } \\
\text { - Describing } \\
\text { settings in the } \\
\text { past }\end{array}$ & $\begin{array}{l}\text { - Expressing } \\
\text { opinions and } \\
\text { emotions } \\
\text { - Narrating in } \\
\text { the past }\end{array}$ & $\begin{array}{l}\text { - Tallking about } \\
\text { weather } \\
\text { - Extending, } \\
\text { accepting, } \\
\text { refusing } \\
\text { invitations } \\
\text { - Giving advice }\end{array}$ \\
\hline
\end{tabular}

Table 9

${ }^{15}$ Allen \& Paesani (2010) 
Table 10: Initial Design of FSU Curriculum

\begin{tabular}{|c|c|c|c|c|}
\hline $\begin{array}{l}\text { Text } \\
\text { Type/Genre }\end{array}$ & Structure & $\begin{array}{l}\text { Language } \\
\text { Aspects }\end{array}$ & $\begin{array}{l}\text { Communicative } \\
\text { Intention }\end{array}$ & Strategy \\
\hline $\begin{array}{l}\text { Text Type: } \\
\text { Short Stories } \\
\text { Genre: } \\
\text { Personal } \\
\text { essays } \\
\text { narratives }\end{array}$ & $\begin{array}{l}\text { Structure: } \\
\text { Stages: } \\
\text { Orientation, } \\
\text { Complication and } \\
\text { Resolution } \\
\text { Phases: } \\
\text { Setting, } \\
\text { Description, } \\
\text { Episode, } \\
\text { Problem, } \\
\text { Solution, etc. }\end{array}$ & $\begin{array}{l}\text { Particular } \\
\text { linguistic aspects } \\
\text { of short stories. } \\
\text { Example: } \\
\text { Past tense of } \\
\text { verbs }\end{array}$ & $\begin{array}{l}\text { Specific } \\
\text { communicative } \\
\text { intentions within } \\
\text { personal essays. }\end{array}$ & $\begin{array}{l}\text { Direct } \\
\text { experience. } \\
\text { Drawing } \\
\text { inferences. } \\
\text { Summarizing. }\end{array}$ \\
\hline
\end{tabular}

The curricular progression can be illustrated in more detail by focusing on a specific theme with a strong emphasis on personal recounts and accounts, exercises, and final composition. Our semester's key linguistic features included a reference to specific participants, places, events and circumstances, colloquial expressions, and use of the past, especially the past perfect and imperfect, and future tenses. 


\subsubsection{Field, Tenor, and Mode}

The specific pattern of field, tenor, and mode can be adjusted by the individual learners to assert their presence in a particular context:

Specifically, SFL claims that understanding the construction of genres requires the realization of three types of linguistic resources in text: ideational resources that build the field or content of a text; interpersonal resources that construe tenor, or attitudes, social relations, and evaluations in a text; and textual resources that construct mode or the flow of information and discourse in a text." (Byrnes, 2011:51).

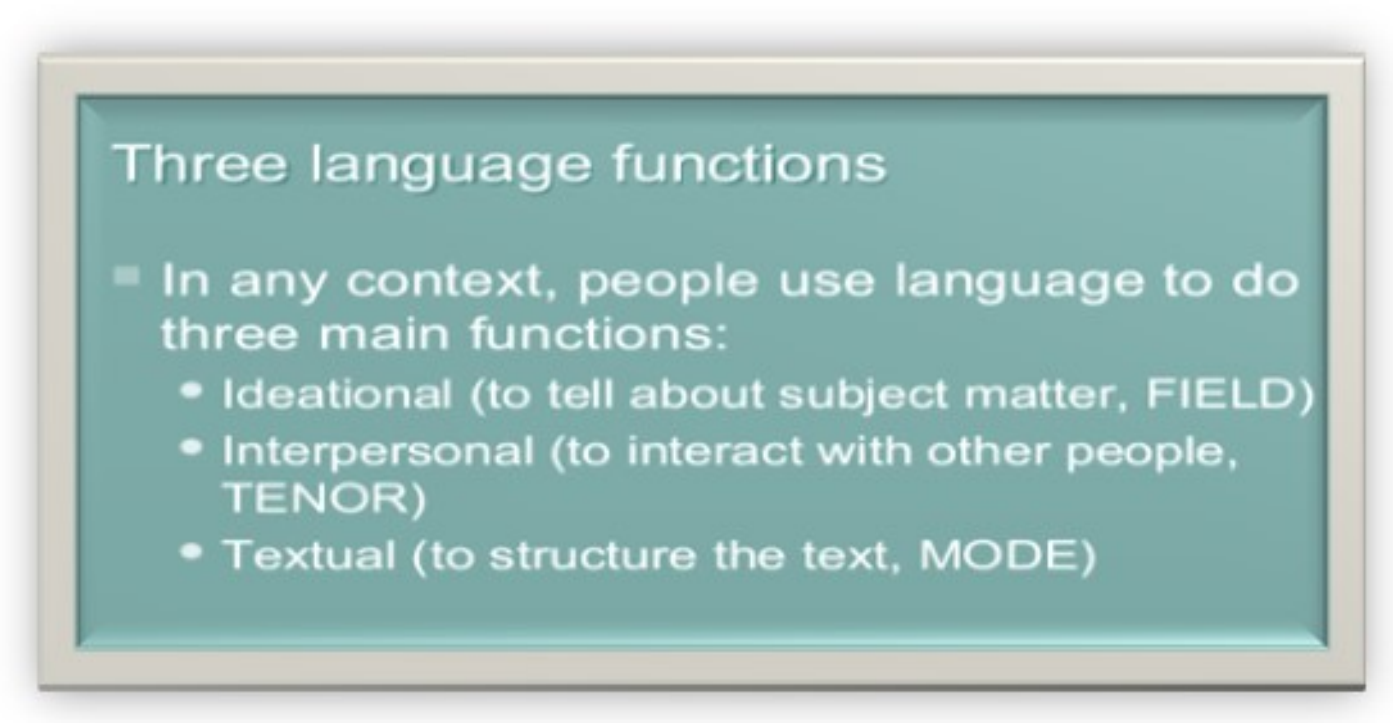

Figure 16

- Field refers to what is taking place, the nature of the social action, and the objectives of using language in a determined situation: what is it that the participants are engaged in, in which the language figures as some essential component. 
- Tenor refers to the participants that take part in communication, to the roles and social positions that participants have: what kind of role relationship obtains among the participants, including permanent and temporary relationships of one kind or another, both the types of speech role that they are taking on in the dialogue and the whole cluster of socially significant relationships in which they are involved.

- Mode refers to the role that language plays, to what participants expect language to do for them in that situation: the symbolic organization of the text, its function in context, including the channel (if it is written or oral or a combination of both) and also its rhetorical component, i.e., if we are able to persuade, teach, state, etc. through the text. ${ }^{16}$

${ }^{16}$ Following Halliday, M.A.K. and R. Hasan definitions, 1985. P.12 
Generic Example of Personal Essays Progression in our Curricular Level II:

\begin{tabular}{|l|l|l|l|l|}
\hline Genre & $\begin{array}{l}\text { Pedagogical } \\
\text { Context }\end{array}$ & $\begin{array}{l}\text { Social } \\
\text { Setting }\end{array}$ & $\begin{array}{l}\text { Participant } \\
\mathrm{s}\end{array}$ & Key Linguistic Features \\
\hline
\end{tabular}

\begin{tabular}{|c|c|c|c|c|}
\hline $\begin{array}{l}\text { Personal } \\
\text { Narrative/ Diaries }\end{array}$ & $\begin{array}{l}\text { "Free time and } \\
\text { Entertainment" }\end{array}$ & $\begin{array}{l}\text { Student's } \\
\text { Trip to } \\
\text { Andalucía }\end{array}$ & $\begin{array}{l}\text { Students, } \\
\text { Teacher }\end{array}$ & \\
\hline $\begin{array}{l}\text { Personal } \\
\text { Narrative/Short } \\
\text { Story }\end{array}$ & $\begin{array}{l}\text { "Free time with } \\
\text { Family" }\end{array}$ & $\begin{array}{l}\text { Family } \\
\text { Summers }\end{array}$ & $\begin{array}{l}\text { Students, } \\
\text { Family }\end{array}$ & $\begin{array}{l}\text { Variation of sentence structure, } \\
\text { present perfect and narrative } \\
\text { past, idiomatic expressions, time } \\
\text { expressions, specific }\end{array}$ \\
\hline $\begin{array}{l}\text { Personal } \\
\text { Narrative/Letter }\end{array}$ & "Friendship" & $\begin{array}{l}\text { Abroad } \\
\text { program in } \\
\text { Spain }\end{array}$ & $\begin{array}{l}\text { Friends, } \\
\text { Students }\end{array}$ & participants \\
\hline $\begin{array}{l}\text { Personal } \\
\text { Narrative/ Short } \\
\text { Story }\end{array}$ & $\begin{array}{l}\text { "My Future } \\
\text { Plans" }\end{array}$ & $\begin{array}{l}\text { "Back in the } \\
\text { USA" }\end{array}$ & $\begin{array}{l}\text { Students/ } \\
\text { Teacher }\end{array}$ & \\
\hline
\end{tabular}

Table 11

It was of greatest importance to integrate assessment and pedagogy into the curriculum because it "enables educators to look at macro levels intended learning outcomes as stated, observe the nature of language use by learners in particular performances, and adjust educational activity accordingly." (Huang and Mohan, 2009:17).

The same generic properties outlined for task requirements served as the criteria for deciding effective task completion. If FL writers are asked to reproduce a genre that consists of certain obligatory moves, each of which is realized with specific lexicogrammatical features, both the writer and the instructor have clear guidelines to assess whether they were met. 


\subsection{Generating a Potential Writing Profile for our Level: Discourse, Sentence, and Lexicogrammatical Characteristics Expected.}

Shifting from word to phrase to sentence to paragraph to coherent writing event towards a genre-based functionalist approach." (Byrnes, 2011:91).

Answering Question 1.2 How to monitor and negotiate curriculum and pedagogical actions through forms of assessment.

In an ideal introductory-level II, writing tasks are brief, one page to one and a half, frequent, and tied to a particular theme or instructional unit. These tasks often are realized along with the oral practice, individually or in groups. Preferably students work with texts, including web-based, that provide information about activities of daily life, language acquisition, and cultural practices. They are practical tasks such as seeking and giving information, short personal narrative, and matters pertaining to daily life and recreational events. The attentional level is located at and below the sentence level.

\section{Level-Specific Learning and Instructional Goals for Writing}

Three assessment criteria for writing development were defined: breadth of obligatory and optional genre moves, depth of content information provided in each of these moves, and the quality of language use at the discourse, sentence, and lexicogrammatical level in line with genre expectations. (Byrnes, 2002).

With this in mind, I outlined the following:

LANGUAGE FOCUS: LEVEL II

Focusing on the sentence level, there is now a conscious development from the simple to the complex sentence and the highly specified chronological narrative 
context. It has an aspect of solidifying known syntactic and morphological features, which means an expectation of higher accuracy.

With a straightforward chronological narrative that parallels the evolving events, a considerable degree of accuracy and variation of expression was possible at the end of the semester.

\section{At the Discourse Level}

Using the narrative focus on topics, background foreground, presumed known and unknown needs to be incorporated in order to highlight relationships between meaning and form.

Introduction of simple connectors, and organizational patterns such as chronology, comparison, contrast, cause, and effect. Other intentions are: registering agreement or disagreement with a position, some expressions, and weighing of opinion on the issues introduced by the themes of the course. Greater descriptions of people, places, and events will need to be practiced separately.

Cohesive devices and forms of information management at the paragraph level: introducing, continuing, ending an episode; indefinite, definite, and demonstrative articles.

Coherence functions in order to go beyond the episode or paragraph.

This level sets up a crucial development in subsequent levels-namely, vocabulary expansion, and lexical accuracy, for example, prepositions and phrases, conjunctions, and adverbials ('a pesar de' 'aunque' 'mientras'17).

\footnotetext{
${ }^{17}$ In spite of, although, however
} 


\section{At the Sentence Level}

Functionally, verb centrality is tied to the increasing use of various forms of past narration in different contexts (oral vs. written, formal vs. informal), the possibility of expressing one's stance in overly evaluative or in less evaluative terms, in a more directly involved or matter-of-fact fashion, or as action.

Verb forms used included the narrative tenses and their relationships in different modes/genres of language: Pretérito Perfecto/Pretérito Indefinido, Preterito Imperfecto/Preterito indefinido, Futuro próximo/Reflexive verbs, Regular/Irregular Futuro simple, Regular/Irregular Futuro Perfecto. Ways of expressing habitual performance with Solia ${ }^{18}$ needed to be included, as they tend to occur in writing tasks. Particular attention to plural formation.

\section{At the Lexicogrammatical Level}

The vocabulary acquisition is best completed through semantic fields that are collaboratively developed from the texts so that words can be connected in groups with a common element such a theme, semantic associations, or the formal relations used to form derivations of these words.

These semantic fields can be language-based (el amigo, la amiga, ser amigos), concept-based (ser feliz/to be happy), or both. Writing tasks included these possibilities and feedback should further draw students' attention to them.

This level sets up a development that is crucial in subsequent levels-namely vocabulary expansion and subtle use and lexical accuracy.

\footnotetext{
${ }^{18}$ Used to
} 
In addition, a useful classification about the treatment of features and distinguishing its different sentence-levels in the writing profile became a helpful guide to students:

$$
+,++, V^{19}
$$

+ Intentional teaching of a critical feature at this level but that it will need a longer period of time to develop a satisfactory level.

++ Something previously introduced that needs focus treatment to highlight accuracy before patterned errors have a chance of settling in.

V Feature that is carried along (like others) with the expectations of improvement as students have more opportunities for use (e.g., word order in subordinate clauses).

-Specific emphasis and weighting of features for FSU level II:

\section{+ Focused Treatment by Way of Intentional Teaching of the Feature}

Narrative tenses and their relationship in different modes/ genres of language use;

Cohesive devices between sentences, for example, introducing new information, a continuation of old information (actors, places, and events), and other information management features at the paragraph level, such as markings beginnings and endings, summation, comparison, and contrast.

++ Focused Treatment in order to Assure the Accuracy of Previously Taught Material.

Differences between Saber/Conocer.

Different pronouns and correct use: $m e, t e, s e, l e$, os

\footnotetext{
${ }^{19}$ Byrnes et al. (p.91, 2006)
} 
Prepositions, or links to fixed expressions, particularly verbs;

Verb position in major sentence patterns (statement, question, compound tenses,

subordinate clauses)

Expression of time

Plural formation

V Carried Along

Comparisons: más que, menos que

Conjunctions: por, para

Simplex discourse markers beyond simple chronology, addition or contrast: 'pero,' 'por supuesto,' 'un ejemplo,' 'si uno compara.'20

${ }^{20}$ But', 'of course', 'an example', 'if one compares'. 


\subsection{Writing Instruction: Rothery's and Harkness Pedagogy}

A former Exeter English teacher once wrote:

People learn by doing—by reading, writing, thinking, talking, yes, and by listening—but not just by sitting there." ${ }^{21}$

At the beginning L2 learners need more structured exercises to learn the grammar of the language, later on, more creative tasks help progress from recitation into communication: Because bright students derive satisfaction from seeing and applying structure, they learn readily from pattern drills, verb synopsis, or translations, but they also need the opportunity to formulate sentences of their own...to play with the structures they have learned, and to respond spontaneously. (Heskel, 2008:77).

Rothery's 1996 presentation as a circle allows students and teachers to work recursively as they prepare their writing assignments:

-His first stage of Negotiating Field focuses on building up writers' knowledge about the subject matter to be discussed and involves understanding the discourse, informing and shaping the topic.

-The Deconstruction Stage is the second pedagogical state, and it is accomplished by introducing students to model texts of the genre and deconstructing them for the following textual attributions: Context of culture (identifying its user(s) and purpose) and situation, schematic structure, and linguistic realization of structural stages.

\footnotetext{
21 The American Scholar, Autumn 2016:34
} 
Figure 17: The Teaching and Learning Cycle. ${ }^{22}$

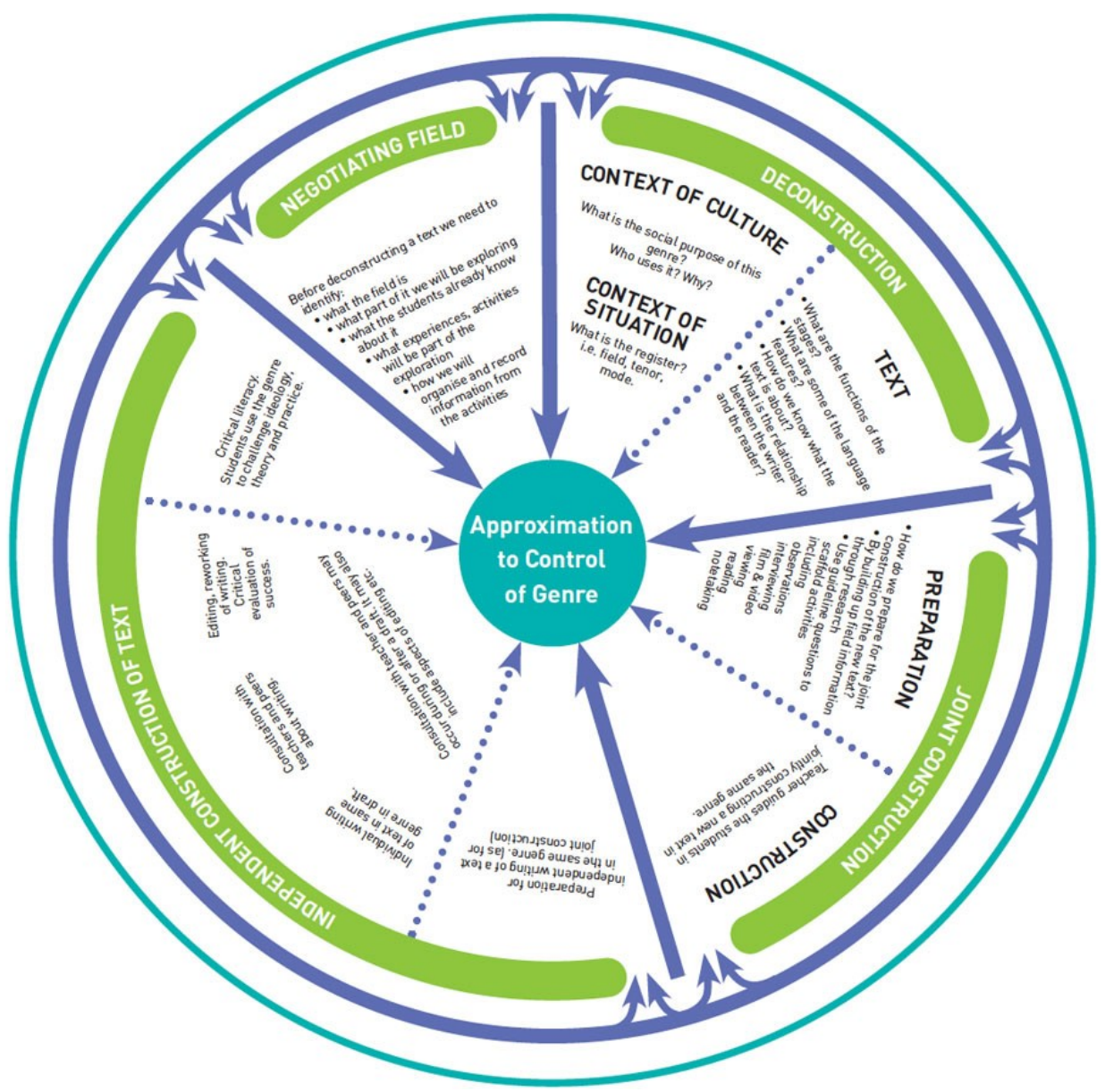

The purpose of the Worksheet in Figure $17^{23}$ is to focus on the text's generic properties and its message system.

In the next class meeting, each aspect of the genre is reviewed, discussed, and expanded. This was realized in the Harkness way, where reviewing students' independent homework in the class led to the sharing of information and expansion of their text's understanding. Learners are expected to work through the text on their own outside of class but always with the assistance of a detailed worksheet that focuses their attention on salient textual characteristics.

${ }^{22}$ NSW Department of School Education, 1992

${ }^{23}$ Original size figure in Annex 9.6 
-As far as Deconstructing the Context of Situation, SFL definition of the configuration of the three register variables: field, tenor and mode offer an analysis that provides considerable benefits for students because it enables them to reflect, critique and understand which aspects of the genre they need to appropriate if they are to produce their successful versions.

For students, even if they are not familiar with these concepts, it is paramount to understand the importance of the subject matter (field), the relationships between interactants (tenor), and the role that language plays in the interaction (mode). Specifically, students are asked to think about how the text is to be delivered or, in other words, how language is used to organize the information in the task. 
Study of the Personal Essay Genre Moves

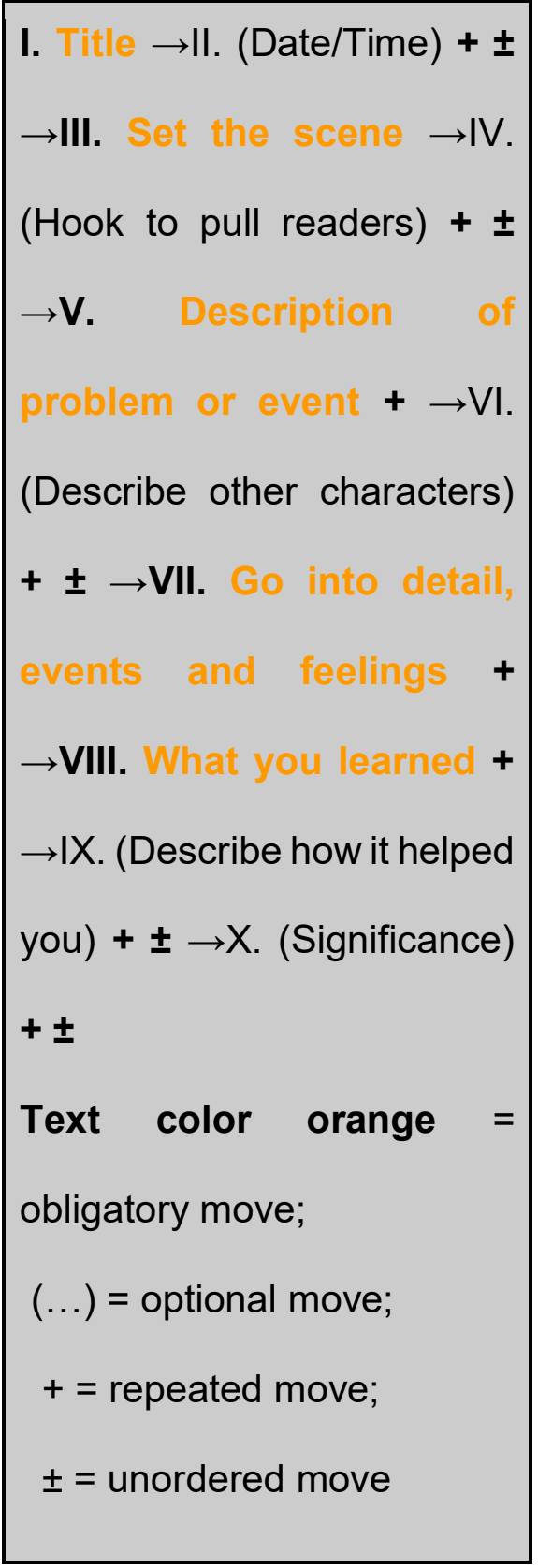

Table 12 
The following is an example from my FSU class of a PE exercise about the topic of "Summers: Describe what you used to do during the summer when you were growing up"24 using the imperfecto and indefinido past tenses. They already knew the vocabulary and had been practicing all tenses in previous exercises. No translation was provided at this stage.

PIRINEOS, VALLE DE ORDESA, VERANO DE 1970

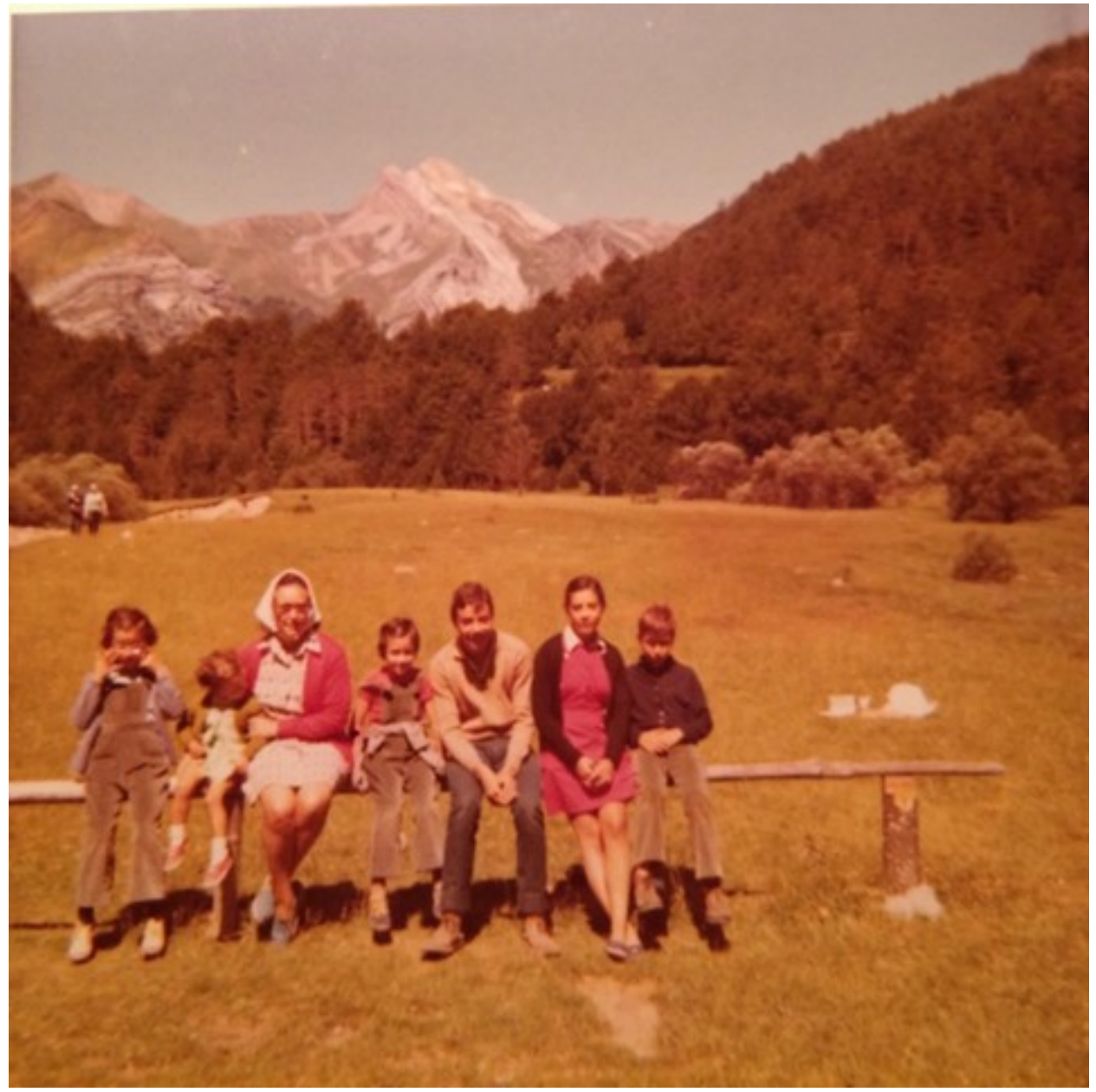

Estos son mis hermanos, yo, y mi madre en 1970. Fue nuestro primer viaje al Valle de Ordesa, después fuimos los siguientes 11 veranos durante el mes de julio.

\footnotetext{
${ }^{24}$ Worksheet 2
} 
Solíamos levantarnos muy pronto para hacer excursiones durante el día.

Siempre nos llevábamos un picnic que nos preparaba el hotel para comer a mediodía.

Normalmente cuando llegábamos a la cima; después descansábamos y bajábamos otra vez. Otra cosa que hacíamos, que nos encantaba, era quitarnos las botas al finalizar la excursión y meter los pies en el agua helada de los ríos, ¡como dolía!

Los pies quedaban como nuevos.

Red $=$ Past Simple Green $=$ Past Perfect

These are my siblings, me, and my mother in 1970. It was our first trip to Valle de Ordesa, then we went for the next 11 summers during the month of July. We used to get up very early to hike during the day. We always used to have a picnic prepared by the hotel for lunch at noon. Normally when we reached the top; afterwards we would rest and walk down again. Another thing we used to do, that we loved, was to take off our boots at the end and put our feet in the icy water of the rivers, how it hurt! The feet were as good as new. 


\section{TAREA 22/FEBRERO}

-Ahora escribe 5 frases describiendo algún verano cuando eras pequeño/a:

-Incluye verbos en P. Indefinido con acciones.

-Escribe frases con el P. Imperfecto con descripciones (no acciones).

-Utiliza mientras y solía + infinitivo.

-Incluye algo que hacías en repetidas ocasiones.

-Habla del tiempo, en imperfecto por supuesto.

-Si imaginas un evento específico en un verano concreto, jserá más fácil!

-Now write 5 sentences describing a summer when you were little:

-Include verbs in Indefinite/simple Past with actions.

-Write phrases with Imperfect Past with descriptions (not actions).

-Use while and used to + infinitive.

-Include something you did repeatedly.

-Speak about time, with imperfect of course.

-If you imagine a specific event in a specific summer, it will be easier! 
The use of my family's actual photo helped to unveil more and more details about ours and their family's dynamics, even more with subsequent exercises. Such as the table manners task and the Thanksgiving example, where we discussed different traditions in different countries, and I asked about leaving the table at Thanksgiving. One of the students said, "in my case, no one will notice that I leave." The statement showed that our class had become open and safe enough to make such an intimate declaration.

The students followed first my short example to make sure they included the lexicogrammatical features required for the task. As Martin indicated, genre "represents at an abstract level the verbal strategies used to accomplish social purposes of many kinds...they can be thought of in terms of stages through which one moves...to realize a genre." Some stages are obligatory others are optional, he continued, both are considered the genre's schematic structure. (Martin,1985:251).

The worksheet \#2 that was given guided them about the language of the text and the grammatical and rhetorical devices. The examination is done individually, for homework, first with the help of an exercise that asked to identify specific lexicogrammatical features in the text. Then in the next class, a discussion was necessary so that additional marked language can be identified. In this way, students become accustomed to analyzing texts for how language functions to affect a particular meaning.

Because each communicative purpose is realized with specific linguistic features, each stage of the genre has its own specific linguistic realization. The focus was on associating those linguistic features with the functions of distinct generic stages.

Further analysis of different examples of PEs is beneficial. It will reveal patterns of language used for obligatory moves that could then be emphasized in instruction. 
With the Harkness methodology to expand students' role in a class, teachers must minimize their own. This is at the center of Harkness:

...they must avoid doing for students what students alone or with the help of classmates can do for themselves. Instead of explaining, teachers should try to lead students to discover the grammatical structure or idea for themselves. ...make the students correct the sole source of drills, questions, corrections, and answers...demand that students fulfill those functions for each other." (Respecting the Pupil, 1981:81).

One of the reasons that what they learnt remained was because they had to find out themselves.

\subsubsection{Principles of scaffolding and modeling for instructors}

One specific example of scaffolding at work, in genre-based pedagogy, is its approach to vocabulary development. Vocabulary is gained over a long period of time and requires active engagement by the learner, so it helps that the understanding of a word's meaning is related to its actual usage in the specific genre. In my own SLA, my preferred way to learn vocabulary was through reading the day's newspaper and with a dictionary by my side. Also, words are understood in terms of their interaction with grammar and the text's context affecting the meaning.

An exercise of semantic associations is interesting because it is a joint exercise and expands their vocabulary. 
For example, in the theme of Initiation:

Growing up. "One way or another, we all grow up.":

\section{crecer/to grow up}

- agrandarse/to get bigger, aumentar/to augment, acrecentar/to increase, desarrollarse/to develop, estirarse/to stretch

- Antónimos: disminuir/to decrease

- envalentonarse/to be brave, atreverse/to dare, animarse, decidirse/to decide

- Antónimos: arredrarse/to get scared

- progresar/to progress, prosperar/to prosper, adelantar/to improve, medrar, subir/to go up

- Antónimos: bajar/to go down, reducir/to reduce

In Context:

Yo crecí cerca del mar. I grew up by the sea.

Marcos creció solo un centímetro el año pasado. Marcos only grew up a centimeter last year.

El crecimiento del uso de los móviles es imparable. The growth of cell use is unstoppable.

Frente al peligro los valientes se crecen. When facing danger, the brave gets stronger.

El río estaba muy crecido. The river was overflowing.

Al final todos crecemos. At the end we all grow up.

Creciendo en los años $70 . .$. Growing up in the 70 s...

Vocabulary that belongs to the semantic field and word family (and lexical sentence collocations) provides learners with scaffolds that reduce their cognitive load during writing.

Students practice the vocabulary in class, in homework, and then use it on genre-based writing tasks. When following this approach, it has been proved that learners acquired 
lexicogrammatical areas beyond their traditional expectations, or otherwise. (Sprang, 2003)

At this stage, teacher-learner interaction primarily takes the form of written feedback, especially on the first draft. At this level, a simple code was used and involved the language features listed on the writing task as the most essential for successful completion.

Task organization, Content and Language (grammar), and Vocabulary were the categories used for assessing, with a grade for each one, which varied reflecting the emphasis or level in that particular task. For example, if students are producing a genre for the second time within a level, the personal letter, there might not be the need to weight the task category as much as the language because they are already familiar with the task conventions and not so much with the required lexicogrammar.

All three categories play a role; if a particular obligatory move is omitted, then the language features required to carry that move will also be missing. 
Sentence stems and Semi Fixed expressions for Scaffolding Learner's ability to give a recommendation and write a hypothesis in a level IV Spanish course ${ }^{25}$.

Table 13

\begin{tabular}{|l|l|}
\hline LEVEL III & \\
$\begin{array}{l}\text { Recomendaciones } \\
\text { En mi opinión... }\end{array}$ & $\begin{array}{l}\text { Recommendations } \\
\text { I am of the opinion/view, that ... }\end{array}$ \\
\hline Por un lado...por otro lado... & On the one hand ... on the other hand .... \\
\hline Es mejor que (verbo/subjuntivo) ... & Is better than (Subjunctive/verb) ... \\
\hline Generalmente, frecuentemente, normalmente & Generally, frequently, normally \\
\hline Siempre...nunca... & Always.... never... \\
\hline A menudo...a veces & Often.... sometimes.... \\
\hline Por eso... & for that, because of that... \\
\hline Sin embargo & Nevertheless \\
\hline LEVEL IV & \\
\hline Hipótesis ¿Qué hubiera pasado? & Hypothesis, what would have happened? \\
\hline Si hubiera tomado diferentes decisiones & If I had made different decisions. \\
\hline Si hubiera elegido otro camino. & If I had chosen a different path \\
\hline Si hubiera dicho algo en ese momento. & If I had said something at the time. \\
\hline Arrepentimientos & Regrets \\
\hline Si hubiera educado a mis hijos de otra manera.... & If I had brought up my children in a different way... \\
\hline ¿Qué hubiera hecho mejor y de qué manera? & What could I have done better, and how? \\
\hline Te aconsejo... & I advise you to... \\
\hline Debes...(verbo) & You should... \\
\hline Imagina si....nunca ocurrió & Imagine if......never happened \\
\hline
\end{tabular}

${ }^{25}$ Saint Anselm College 


\subsubsection{Harkness discussions as a narrative in class and independent construction: PE-based writing tasks and drafts.}

Writing is composing, and composing is a decision-making process of great complexity, even on the simplest level. It is more than grammar or spelling or punctuation. It is, above all, thinking, feeling, ordering, organizing. (Respecting the Pupil, 1981:15).

I chose storytelling as a primary characteristic of language learning within my curriculum. In my class, students read stories from language memoirs, listened to stories from my/their childhood, answered questions and practiced grammatical structure and vocabulary from stories, and finally learnt to write their own.

For this purpose, it was essential to consider the class as a space where students need to be able to process and resolve their lack of understanding and allow them time to think and write, right in the middle of class. (The Lawrenceville, 2015:220).

It is useful to think as each class, each discussion, as a potential "paper" written, out loud at the beginning: “... As I'm there in the moment to help the individual student articulate and advance ideas in a series of paragraphs in a critical essay...I insert my comments...not imposing my agenda, but steering the authors in the direction that will be most fruitful. If the teaching of writing is helping students to become their own draft editors, Harkness teaching helps them to become their own teachers". As a Harkness teacher does not claim to possess all the right answers and meanings, students are held accountable for their own learning. (Respecting the Pupil, 1981:103-102). 


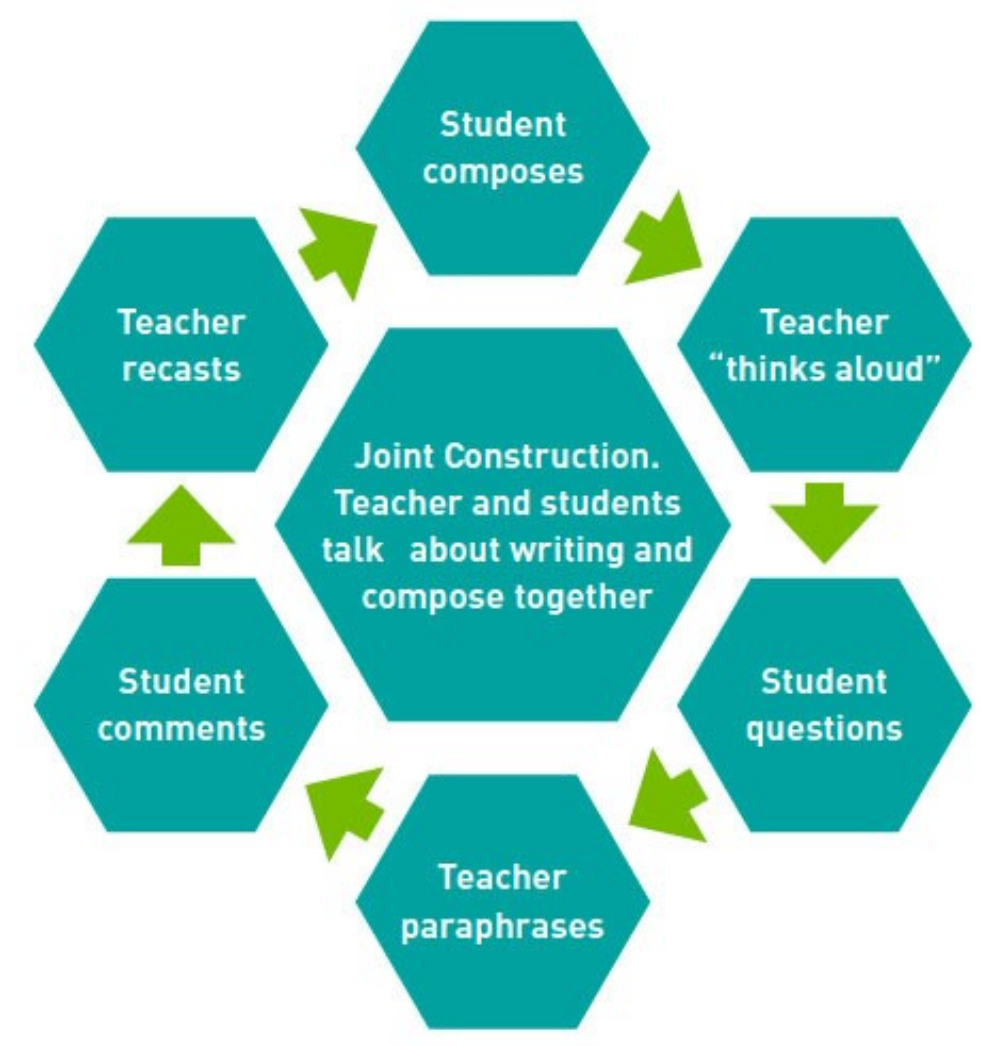

Figure 18: Joint Teacher and Students Writing Construction

At the beginning of the 2016 semester, one of our tasks was to learn different acceptable or not behaviors at a social gathering. I projected a list of traditional customs in different cultures. Then we compared it with their thanksgiving experiences. We gathered together a story, and students practiced the idea of "discussion as narrative." With this method, students begin to see that discussion in class requests the same level of connection and meaning of a story.

At the same time "by stepping away from the table for the exercise, teachers let students know they are trusted to carry conversations on their own." (Hassan, 2015:69). 
A useful example of how to use L1 speaking and writing in preparation of discussion that could also be applied in SLA:

Using the standard bookends of a Western fairy tale "Once Upon a time "and "They lived happily ever after" ...One student begins the tale and then tosses a tennis ball randomly across the table to invite the next speaker to continue the story, every member has to add 2 or 3 sentences to the story but can only speak once. At the close of "happily ever after," the speaker throws the tennis ball to the last person who has to retell the story with the help from the group.

I then move back to the table and put two questions on the board:

-How did it feel to do this exercise?

-What helped the story progress?

By asking the students to write their answers before having to speak them: the more reserved collect their thoughts, the loquacious shape their rambling comments." (Respecting the Pupil, 1981:70) (my emphasis).

For my advanced Spanish class for refugees, I used a similar activity inspired by a Spolin's ${ }^{26}$ theater warm-up game that worked better for L2 learners.

In this case, students would add just one word to the story, another would act as scriber on the board, and we summarized at the end of the exercise together. Practiced at the end of the class, when everybody's brains had been stretched for the day, they soon learned they could relax and be funny in this last combined effort that left them with an accomplished sense of achievement.

Spolin, Viola: https://spolin.com/?page_id=10 
Inevitably there will be moments of silence that teachers and students are not accustomed, it is necessary then to "let the sound of quiet sit so that everyone also knows the value-rather than embarrassment-of our shared silence...most importantly, just as I have worked to have the students trust each other and me, I have worked to trust them." (Respecting the Pupil, 1981:71).

In my experience at the beginning of the FSU term, I had to learn to allow these reflective moments to exist, because they were needed in order for the students to try to create their individual conversations about the texts. Instead I would rush to fill the pauses with more questions, at their expectative eyes. I noticed that they were used to identify the teacher as the person of knowledge. I agree with Stephen G. Kurtz (Principal emeritus, Phillips Exeter Academy) that traditional "Lecturing to a classroom of college students was a snap compared to what this way of teaching demanded". (Hassan, 2015:61).

Writing essays with first and second drafts triggers most students, not only an inner sense of revision but also discovery and knowledge. They need to "figure out something on your own, some question to which you don't have an answer when you start." (Lopate, 2013:43) Usually, they discover what they want to say in the second draft and then start working towards form and accuracy.

In my classroom, I aimed for students to learn Spanish by writing about their own experiences with a series of drafts and corrections, evaluations, and out-loud readings. I would write along with them in all exercises, and my first draft also improved as I share it with them. 
Although writing is generally thought of as a solitary activity, with FL writers being left to their own creative selves, which often fails, the approach here encompasses opportunities for creating classroom communities that are supportive of writing by way of various activities and tasks surrounding the actual writing event.

The creation of these tasks is based on the course content, the PE genre, and the course's particular learning goals.

These are the steps I followed:

- Once a particular unit is selected, and its content materials explored, I then considered the PE as context and exemplified the language acquisition goals for that unit.

- Afterward, I put that task in a context that constituted an authentic need to mean for the learners. That is best accomplished by placing the task in a particular situation.

In this level, as I pointed out before, the writing tasks focus on the personal realm and are contextualized in private, familiar settings (e.g., letter to a friend about their experience of Las Fallas with recommendations, childhood story about their summers).

The SFL framework with the inclusion of the ideational, interpersonal and textual metafunctions in any language use is useful for considering the different meanings that are being constructed: who are the participants, what kind of processes they engage in, and under what circumstances. A task that specifies the participants, involves them in the material and focuses on the time and place of their actions would be perfect for the language and context associated with this level. (Byrnes, 2011:113). 
Analyzing the textual meaning helps clarify the role that language plays, as they talk about events and experiences from their immediate past, in the structure of the information to create cohesion and coherence. In terms of ideational meaning, the participants are specific (the sender and the recipient) exemplified by the personal letter to a friend with recommendations. The verbal processes are a combination of material to relate the events surrounding the situation (the circumstances express location but also causation, angle, and extent) and mental processes for indicating cognition, perception, and affection. The relationship between participants expresses the interpersonal meaning. Once the genre and the situational framework has been determined, the next step is to find examples of that same genre that can serve as models. The PE genre was compatible with the content, exemplified the type of language emphasized at the curricular level, and could be modeled with actual textual examples in order for learners to develop their own narrative.

The Personal Essay intrinsic characteristics of curiosity-driven research, imaginative recounting, pursuing the truth of their experiences by connecting them with their memory, motivated students strongly to find their most accurate written expression of their own voice. 
The subsequent clearly defined schematic structure helped students with their essays. All genre derived writing tasks consisted of three sections: The Writing Task, The Content Focus, and The Language Focus:

- The Writing Task describes the scenario motivating the task: actors, textual mode, and content focus. In addition, the obligatory and optional moves of this genre were included.

- The Content Focus includes specifications about the extent the students are to incorporate text materials from class.

- The Language Focus specifies what kind of language the students should be drawing from to accomplish the task adequately. The guidelines here are linguistic tools for the students as they write, they address discourse-level features such as sentence types, the linking of sentences with the help of markers, sentence-level features like conjugation, word order, and lexicogrammatically features like the use of specific lexical items and collocation.

Finally, all other expectations for the assignment, such as writing process (one or two drafts), and spelling/capitalization, submission deadline, and text length was included. By now, students are used to receiving this degree of guidance before they start writing, and as I mentioned before, such explicit guidelines readily serve as assessment criteria. If a student omits an obligatory move of the genre called for, then the instructor can give 
the student clear feedback and has distinct grounds for deeming the task not entirely successful or unfulfilled.

Students need significant guidance in L2 writing to engage in their creativity and contribute to the formation of their distinctive voices. 
Example of a PE Model and Task Sheet for Assignment \#1 for Spanish Level IV ${ }^{27}$

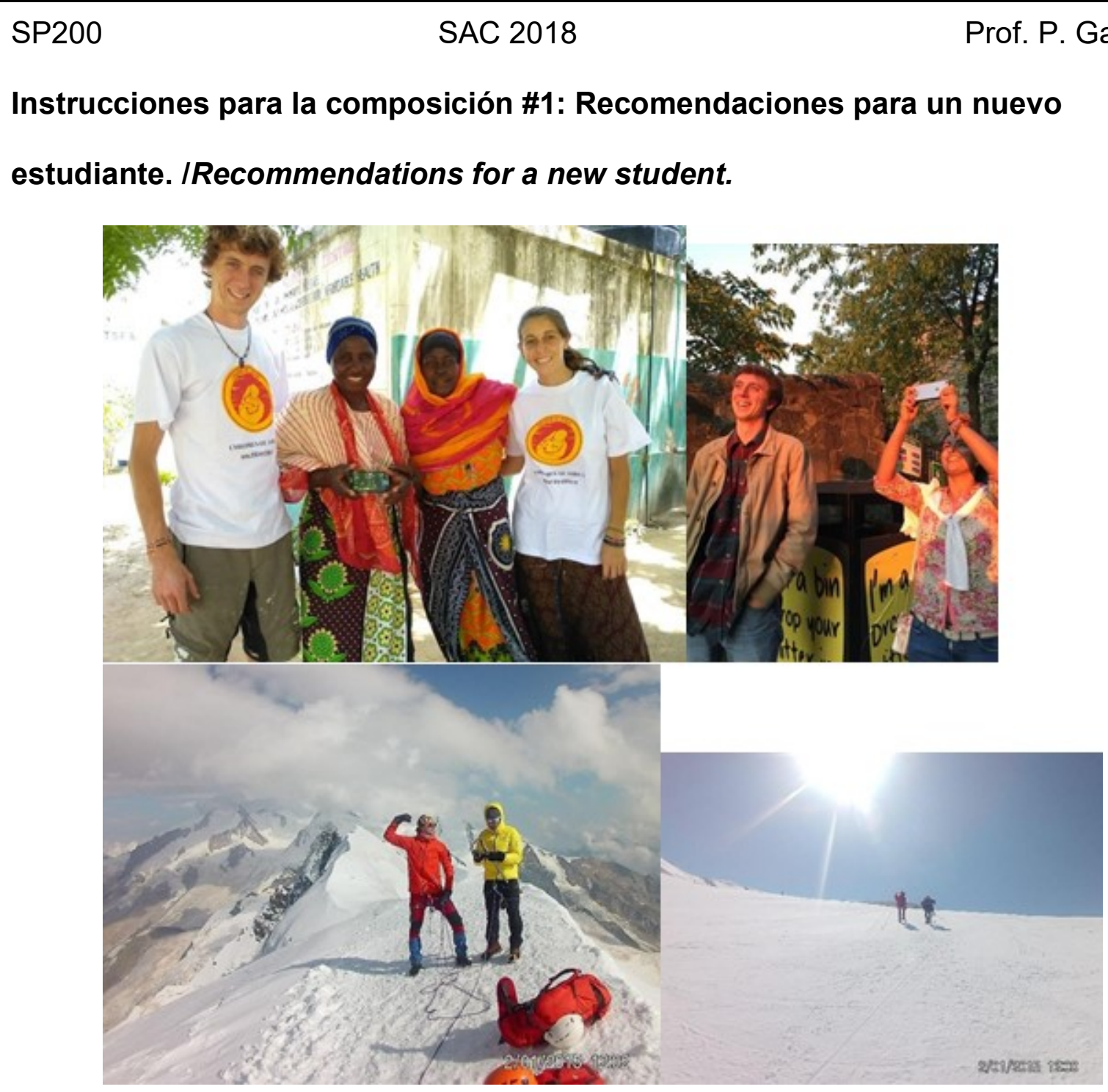

\section{Content}

Carlos después de hacer un voluntariado en Kenia llega finalmente a St. Anselm.

Desde tu punto de vista, que recomendaciones y consejos le darías sobre cómo llegar a Manchester y maneras de transporte, la residencia y tus compañeros, las clases, la comida y otros gastos como libros y cosas que hacer en su tiempo libre.

\footnotetext{
${ }^{27}$ Worksheet 3
} 
A Carlos le encanta toc ar el piano y escuchar música, también es un apasionado de la montaña y le encanta escalar, viajar y las aventuras en la naturaleza, ayúdale a encontrar maneras y sitios donde practicar sus aficiones.

\section{Lexicogrammatical and Language Focus}

Tu redacción debe incluir:

1) Vocabulario de Cap. 13, 14 y $15++$ y otras palabras que tú quieras.

2) El subjuntivo, indicativo e infinitivo. +

3) Palabras de transición: V

Siempre=always Nunca= never Generalmente, frecuentemente, normalmente
A veces = sometimes A menudo= often También = too, also Tampoco = neither
Sin embargo=however Por eso $=$ for that, because of that
Entonces=therefore Afortunadamente=Fortunately Desafortunadamente=Unfortunately
Por ejemplo=for example Por un lado=On the one hand
Sin embargo=Nevertheless
Entonces=Thus, therefore Por otro lado=On the other hand Al contrario= On the contrary
A veces = sometimes A menudo= often También = too, also Tampoco = neither

\section{Writing Process}

La composición debe contener 250-300 palabras (25-30 frases).

La composición debe tener 3 partes: Introducción, Cuerpo (body), Conclusión. 
Debes preparar un bosquejo o borrador en casa después de recibir el primer borrador (draft) corregido por mí, vas a escribir la composición EN CLASE.

\section{Fecha: viernes 5 de octubre EN CLASE ${ }^{28}$}

\section{$\underline{\text { Assessment Criteria }}$}

LA NOTA (grade): Tu composición va a ser evaluada por

1.) el contenido, 2.) el seguimiento (following) de las instrucciones, 3.) el uso correcto de la gramática, y 4.) el vocabulario.

The four categories are weighted as follows: 1) Content 33.3\% 2) Task $33.3 \%$ and Language focus (Grammar and Vocabulary) 33.3\%.

Grades can be improved in the second and final draft in class.

The specific pedagogical steps to ensure that students understand what needs to be done to produce a specific genre is presented next in detail:

To ask why the said is being said, what it implies...whose point of view the writing represents...why it is structured the way it is; what would change, for whom and what price, if the structure were to be changed." (Hasan, 1996b:411).

${ }^{28}$ Example of a student's performance in Appendix 6C 


\subsection{End of level writing task - Prototypical Performance writing Task (PPT) for level II}

Answering question 1.3: Do syntactic patterns match the expectations of the curriculum?

A summative statement has to be produced to describe the prototypical writing performance for each level's end after the idealized writing profile. It translates abstract genre concepts into concrete guidelines and tasks for level writing development at the end of the curriculum.

Each PPT specifies the language resources emphasized at the level as well as a target task. It also helps instructors with clear and realistic goals because knowing what is expected of students at the end of a course makes you more effective in selecting texts, modeling language use, and finally developing writing tasks.

Students were informed in explicit terms about each assignment's expectations and for the course as a whole. The nature of the progression was to be as transparent as possible for students and the teacher.

And finally, the IWP also established clear parameters for assessment: once goals were well understood, it became much more comfortable with assessing whether they were being met.

In general, at level II, students should be able to use written language first to seek and provide information pertaining to daily life, describe their personal and physical circumstances, refer to different places and events and state their opinions. Afterward, in my instructed writing course, the language focus shifts from the simple to the complex 
sentences with dependent clauses that indicate various organizational patterns: chronology and uses of such tenses such as the past perfect; consequences of actions; syntactic structures that express comparison and contrast, cause and effect.

At the functional level, students are expected to construct a coherent narrative: simple descriptions, expressions of opinion, recommendations, or argument at the primary discourse. Students may start being aware of audiences and establishing themselves as authors with individual intentions. Features for syntactic ability included relative and subordinate clause formation.

Prototypical Performance Writing Task for Level II:

"Letter to a friend relating their experience and recommendations about Las Fallas" or PE about a "Summer with their families."29

By the time the students performed the PPT, they had completed other tasks of a similar format. They had become used to attending to generic conventions (structure, purpose, content, linguistic choice) when writing. These tasks started in class and then completed outside because they involved extended, reflective writing.

The PPT, when presented to students, included descriptions of the significant expected language use features in terms of what communication was to be accomplished within the PE genre, what sources of information, content, where to be treated within that communication, and language focus in Spanish (discourse, sentence and lexicogrammatical features).

${ }^{29}$ Appendix 6B PPT for level II 


\section{APPENDIX 6A}

\section{End-of-level Writing Performance Profile, Level II}

Answering Question 1.2 How to monitor and negotiate curriculum and pedagogical actions through forms of assessment

Within the central genre of this level- the personal story- students frequently take an experiential and process perspective in chronological sequencing. Students plan language beyond clause and sentence levels, extending their writing into simple narratives and descriptions, and even basic expressions of opinion or position. They show sensitivity to the nature of the audience (What the audience knows or not, what it needs or want to know, locates the writer as the author and his/her intentions (to retell a story, entertain, describe, inform, express an opinion, recommend). As a result, students could create basic coherent and cohesive texts with a clear paragraph structure.

Accuracy laid on the sentence-level and below, marking features at the lexicogrammatical level, such as gender, number, and tense.

The careful way that these tasks were designed according to level profiles provided tangible data that could be analyzed in different ways to determine the degree to which learner performances corresponded to the stated goals.

Finally, as with previous assignments, the PPT went through first draft and revision stages, and each stage received a grade, encouraging students to produce their best possible writing on the first draft: "...if we are patient and allow the students to correct their errors and rewrite their papers, their pride of authorship will emerge." (Respecting the 
Pupil, 1981:22). I believe this pride is multiplied by ten when the writing is in a second language. 
APPENDIX 6B

PPT for Level II

Answering Question 1.2 How to monitor and negotiate curriculum and pedagogical actions through forms of assessment

Task: Personal essays "A trip to Andalucia" or "Summer with your families."

Since summer is approaching rapidly, you are now reflecting on the summers you used to have. Lazy days were enjoying the weather and all kinds of activities with friends and family. Is it the mountains or the sea you associate with your best summers? What were your family dynamics during these times?

You can also reflect on your recent trip to Andalucia. Looking back, what was the best experience, where would you go back in the future? What would you change? It should contain the following components:

Task 33\%

- Title

- Set the scene

- Description of event

- Go into detail, events and feelings

- What you learned

\section{Content 33\%}

Consider the following items for the separate components of the letter:

- You determine the specific memory for your composition.

- Mention the place and date where it happened.

- Think about a hook to pull the readers in.

- Describe all characters.

- Did you encounter any problems? Causes and effects. 


\section{Language Focus $33 \%$}

\section{Discourse Level}

- Describe, Substantiate

Sentence Level

- Time markers in order to present the chronology of your situation.

- Correct tenses (past imperfect and indefinite) that clarify the order and circumstances in text.

- Verb position in main and subordinate relative (for description) and dependent (because) clauses.

- Use of adjectives for description.

- Cohesion: types of conjunctions and prepositions.

Word Level

- Relevant vocabulary for the topics of travel, family, daily routines, summer.

- Spelling, capitalization, punctuation.

Writing Process: Your composition is due on ; the revision is due on Length: 1-1.5 pages, double spaced.

Criteria for Assessment: The categories task, content and language focus are weighted equally with the language focus further divided into grammar and vocabulary. The total grade results from the component grades. In the revised version you can improve your grade by maximally 2 'steps' (very good correction: upgrade by two steps; good correction: 1 step; mediocre or weak correction: no grade improvement) . 


\section{APPENDIX 6C}

Example of a Student's Performance from Saint Anselm College.

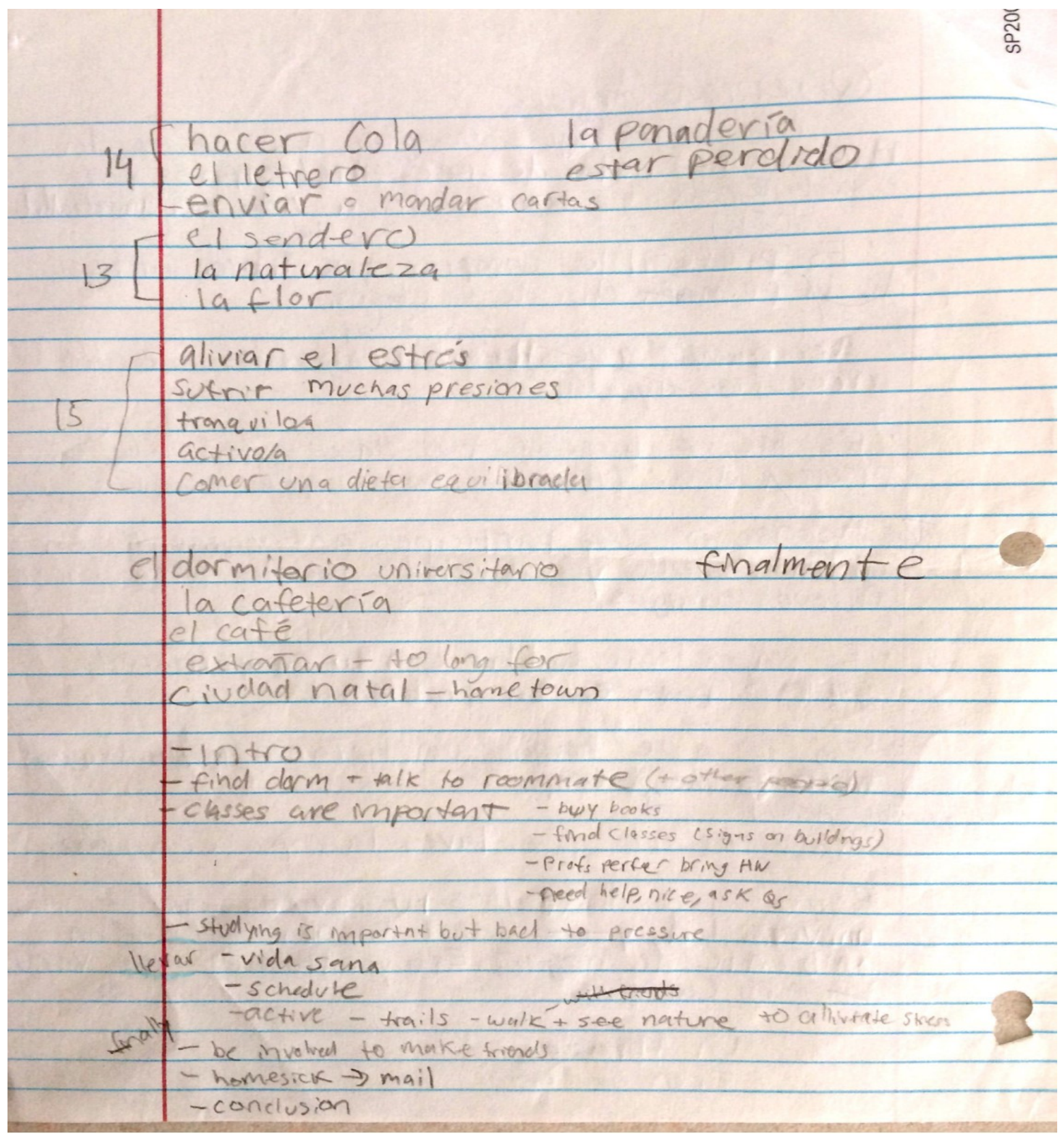

Notes from class: discussion to writing. 
Querida Amiga,

Me alegrodque vengas a Saint Anselm.

Hice una lista de recomendaciónes para

ayudartecon tu transición a vida en universidad: (ä́ti) la k

- Es preferible comprar tus libros antés

de If prim día de las clases.

- Recomiendo que hasas pregantas cuando necesites ayuda.

- Es mejor buscar tus clases antés deva primeap dia. (if you are lost every beilding has sigas)

Te: Aconsejo que participes activamente en algunos clubs y actividades sociales para hacer nuevos amigos.

- Es importante hablar con tu compañera de cuarto para evitar problemas.

sugiero que hagas un horario y practiques manejo de tiempo

con IA OXAAmizacion To

- Recomiendo que laves la ropa a menudo.

Espero que disfrutes tus experiencias en universidad, y saint Anselm tiene $d$ un ambiente de hogar. iEstoy entusiasmada verte to en campus? de

\section{Un Abrazo,} Erin Golden

\section{First Draft.}



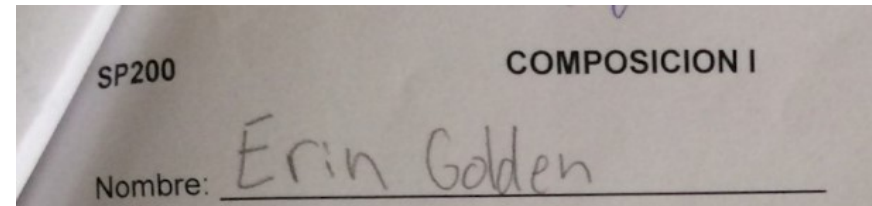

$$
\begin{aligned}
& 3 \text { Gramut Prof. P. Garcia } \\
& 4 \text { Vocab } 25 \\
& \text { Fecha: } 10 / 5 / 18
\end{aligned}
$$

Querida Amiga,

me alegro de que vengas a Saint Anselm. Te quiero decir lo que aprendido aquí. Hice una lista de recomendaciónes Para ayudarte n tu transición a la vida en la universidad.

Primero, cuando llegas al campus, recomiendo que busques tu dormatorio versitario y conozcas tu compoñera de cuarto. Es necesario que hables con tu pañera de cuarto para evitar problemas.

Tus clases son importante. Es preterible que compres los libros antés del primer 1. Sugiero que busques las clases antés del primor día también. Si estás perdide, - Tos letreros en los edifrcios. Los protesores prefieren que traigas la area a cada clase. A veces, los estudiantes nesecitan ayuda. A Fortunadamente os profesores son muy simpáticos. Es bueno que hagas preguntas.

Por un lado, es importante que estudies. Por otro lado, es malo sufrer muchas resiones. Es necesario que lleves una vida sana. Sugiero que hagas un horario y pratiques con la organizacion de tu tiempo. Estat activa. El campus tiene

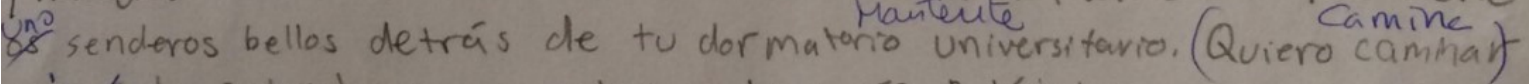
vet la naturaleza para aliviar el estrés. Relájate. mirh Finalmente, te aconsejo de que participes activamente en algunos clubs y actividactes sociales para hacer nuevos amigos. Si extrañas tur familia y amigos en tu ciudad natal, puedes enviarles muchas cartas en el corred en campus.

Espero giv distrutes tus experiencias en la universidad, Saint. Anselmtien. un ambiente de hogar. iEstoy entusiasmada de verte en elampus!

Un Abrazo,

Erin Golden

Final Composition I in Class. 


\section{APPENDIX 6D}

FSU 2016 Spring Roster with their authorization to publish and to work with their compositions.

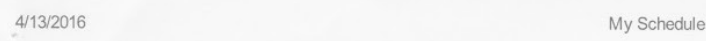

Class Roster

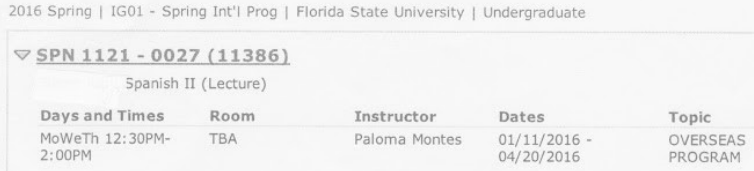




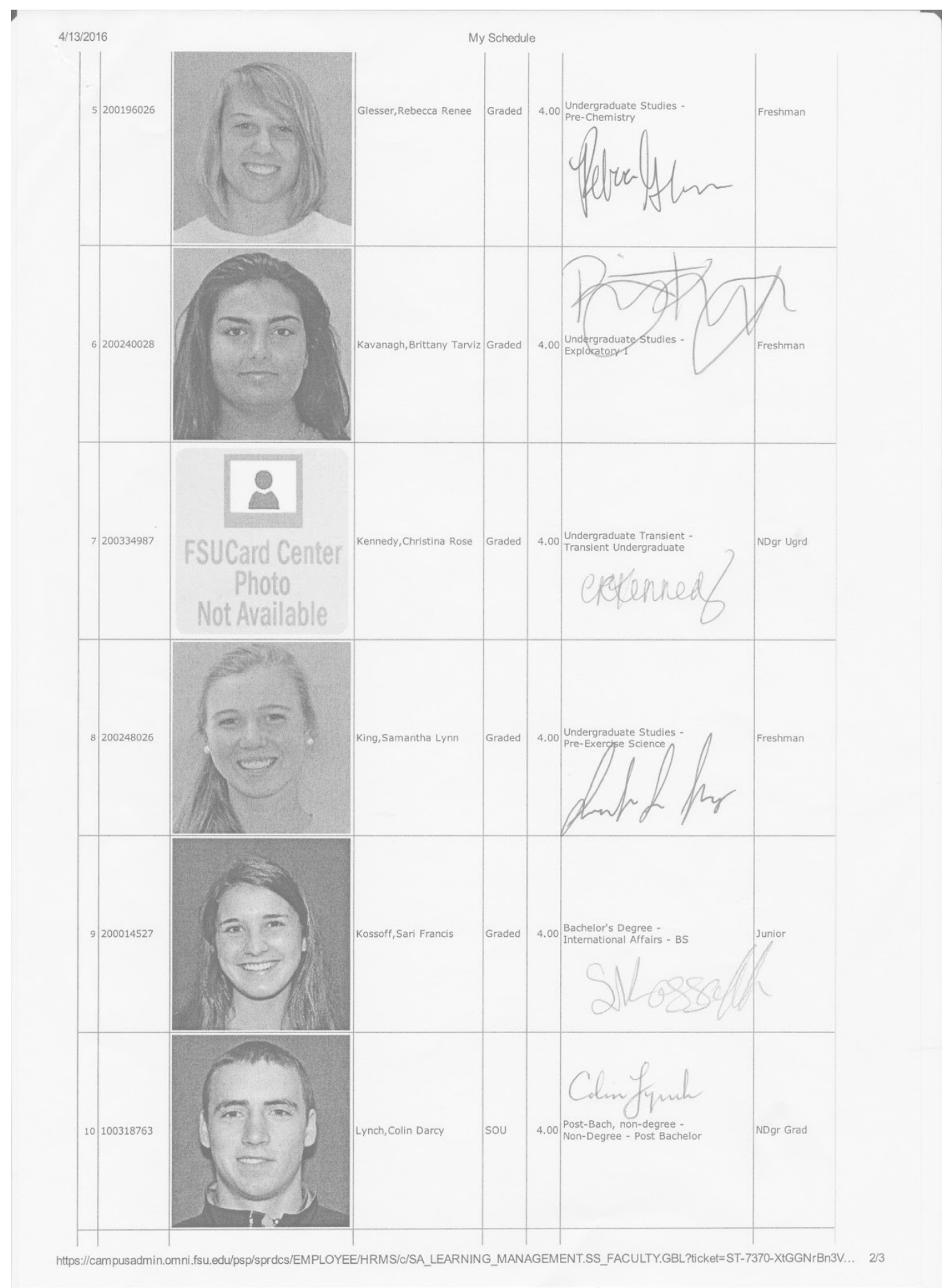




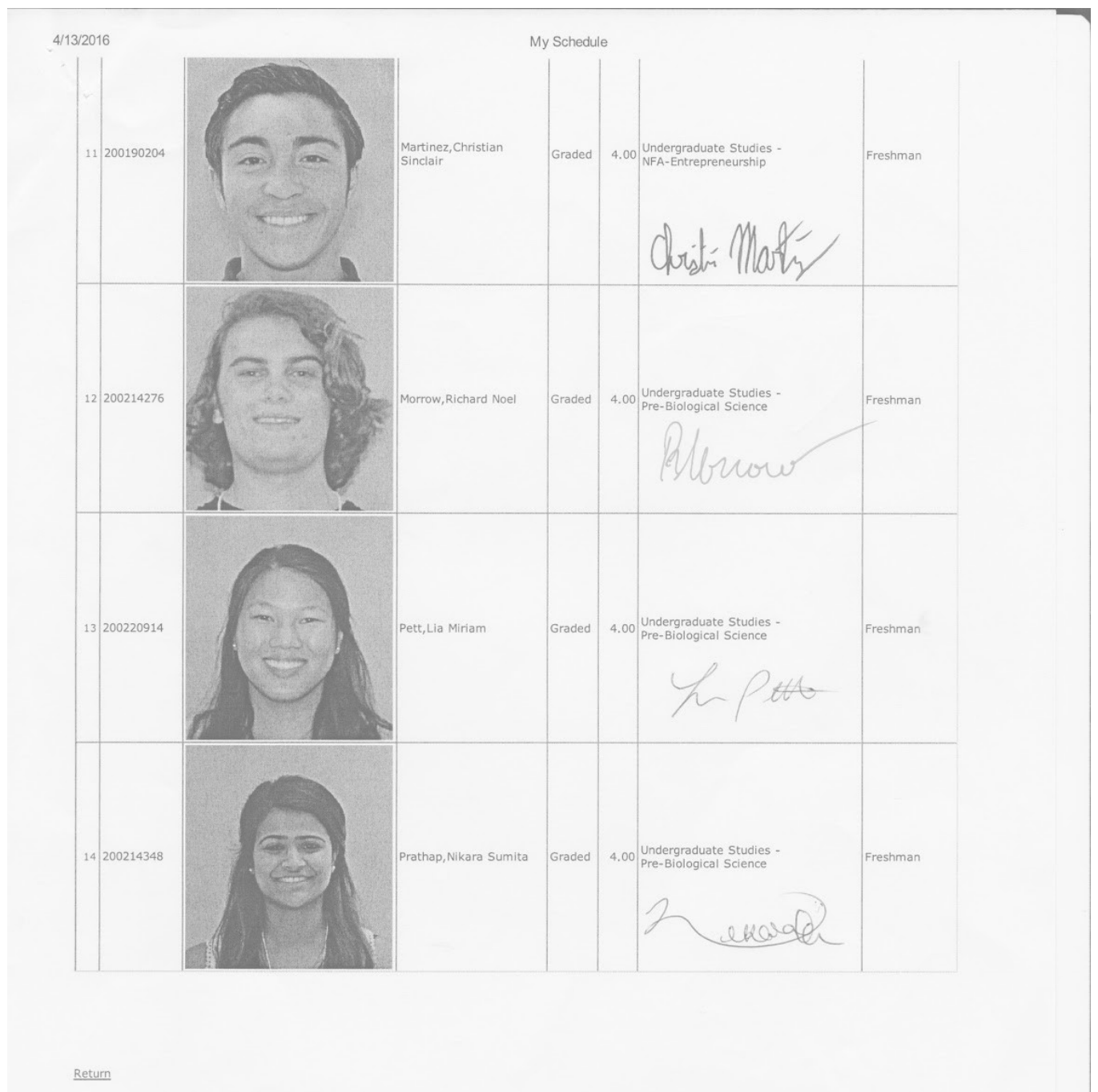

https://campusadmin.omni.fsu.edu/psp/sprdcs/EMPLOYEE/HRMS/c/SA_LEARNING_MANAGEMENT.SS_FACULTY.GBL?ticket=ST-7370-XtGGNrBn3V... 3/3 


\section{RESULTS}

\subsection{Assessment of Foreign Language Student Learning with the Personal Essay Genre Approach}

In order to make the case that learning to write contributes to the learning of content and, ultimately, to the creation of knowledge, we must find linguistic evidence for its evolution across a text. That means that the 'process' of responding to a writerly task should now seek to trace the development of thought in language and, through that thought, the creation of knowledge. Whatever choices L2 writers make in response to a writing task, we propose that to the extent that their compositions show evidence for conceptual refiguration and textual configuration they provide evidence for knowledge construction. (M. Ryshina-Pankova, $\mathrm{H}$. Byrnes, 2013:182).

Research questions pertaining to this chapter:

1.3 How to monitor and negotiate curriculum and pedagogical actions through forms of assessment

(2) How does college-level American FL writers' proficiency final acquisition compare to the same college-level American traditional L2 learners' knowledge?

2.1 Do learners who complete the same curricular level via different instructional pedagogy produce writing with similar syntactic complexity?

(3) How proficient can students become when surrounded by best learning conditions, such as the Harkness method and small class numbers, when introducing genre-based writing tasks throughout the duration of a language course?

3.1 Do learners in different educational settings with an SFL educational approach generate complex syntactic writing as well? 
Much of the genre's applicability is due to the fact that it's relatively stable and conventionalized. In addition, properties can be identified, quantified, and deconstructed. A particular genre can serve as the basis of a writing task, modeled in instruction to facilitate its reproduction. However, to validate this approach, assessment practices need to be implemented to establish what kind of development is taking place. As reported by Norris, educators learned to reconsider the role of assessment by specifying the intended uses of all assessments and developing instruments and procedures for those uses. (Norris, 2008:90).

Furthermore, an assessment was vital to the overall success of the genre-based curriculum in this study because it allowed me to examine how well learners were progressing towards the class goals, and it also provided me with critical feedback, through meaningful target writing tasks, for further enhancement.

After analyzing students' errors in their first drafts, I was able to correct them with exercises in the classroom so that students could work on the lexico-grammatical points that needed further practice.

These exercises were at the sentence level; then, students were expected to apply this knowledge to their revised writing tasks. My intention with these classroom practices was that students were aware of the importance of selecting the correct lexico-grammatical choices to write appropriate and effective texts.

Rather than merely adopting commercial or textbooks assessments, or following the trend of oral proficiency interviews, which always result in teaching and learning reduced to the least common denominator. Assessments should be used in language education for making decisions about individual students, for classroom feedback for both teachers and 
learners, and finally, not less critical for gathering estimations of students learning outcomes for curricular improvement and program accountability. (Norris, 2006b, 2008) Thus, each genre-based writing task was designed to elicit writing performances that would best reflect learners' developing Spanish FL abilities. The task expectations, content, and language focus categories described in their assignment sheets not only guided learners but also served as the basis for teacher feedback and ultimately for assessment of their performance. This clear criterion is often absent from unfocused essay writing, as demonstrated with the parallel course performance.

As I mentioned before, the task itself reminded students of the personal essay structural properties by listing the obligatory moves of the genre discussed in class, and that needed to be incorporated in their own version. The content category was assessed according to the amount and quality of information that was included for each move within the genre. The last category, the language focus, included the quality of the linguistic realization of the obligatory task moves, and it distinguished among discourse, sentence, and lexicogrammatical level features in the PE. 
TABLE 14: Example of Different Students' Take on Same Task

\section{Final Composition II: Intentions for the Future: Opening Paragraph}

S1: "My intentions for the future are very good...I think I will live in Europe, with any luck, in Valencia, Barcelona, or Madrid."

S2: "For next year, I am going to get a job. I want to earn money and to go to school at Tallahassee. I will try to get good grades while I try to conquer my depression."

S3: "In a year I will be studying at Florida State University in Tallahassee and I will continue to try to finish my degree in psychology."

S4: "In this year 2016 I have a lot of intentions and things I want to do. This year I go to many countries, before I go to the United States."

S5: "For this year I will find a job. I need a job to get money to pay for my car and my education."

S6: "My intention for next year is to get the best grades. I am planning to study more and to party less."

At the end when all was said and done, each student adopted a particular approach to each writing task that made it unique.

In genre-based tasks that provide the most effective means for assessing writing development as stipulated within the curriculum: "Descriptions of genres offer testable hypotheses concerning the language demands of different text types." (Brindley, 1994:80) However, rather than focusing exclusively on grammatical correctness, it also included 
the writer's ability to make the most appropriate textually oriented, language-based choices for completing a genre-derived task. It would have been unreasonable and ineffective to expect a mastery of every aspect of the language use they encountered. By proceeding over the course of a semester through multiple iterations of genre instruction, writing performance, assessment, and feedback, the students and I worked collaboratively in a Harkness way to develop valued language and writing abilities.

I was also able within this continuous assessment to reexamine the thematic units and update and adjust the PPT itself, the pedagogy, the texts or profile, or other tasks as needed.

\subsection{Design of Assessment Rubrics with Level-Specific Writing Expectations}

\section{Answering Question 1.3 How to monitor and negotiate curriculum and pedagogical actions through forms of assessment:}

The idealized writing profile for this level, and the summative statement describing the writing performance prototypical at the end of the semester, described the genre-based progression. A rubric ${ }^{30}$, on the other hand, described the range and qualities of performance possible. It provided me with feedback about language development for each of the three categories (task appropriateness and organization, content, and language focus (lexico-grammatical). The language evaluated corresponded with the one found in the level profile and Prototypical Performance Writing Tasks.

\footnotetext{
${ }^{30}$ See in Annexes 9.1 for Scoring Rubric example for Level II.
} 
Rubrics were very helpful as I was teaching with genre-instruction in mind for the first time; they were also available for students to see how the assessment of their writing performance was determined. It was only possible because goals, profiles, and expected outcomes were formulated in advance. There is a need to look at how single tasks fit into the broader curricular framework, how it relates to the thematic unit's goals and the level profile.

Approaching language acquisition from a curricular and literacy-oriented perspective requires that the instructor recognize the long-term, nonlinear, and error-full nature of language acquisition.

This instruction will also be significantly reinforced if the language department, which is part of, establishes clear assessment policies elaborated by both the teaching and administrative staff at their respective class and program levels.

The excellent experience at the Georgetown University German Department could serve as the ideal model for this purpose. Their assessment policies focused first of all, "on students' abilities to use the language meaningfully" 31 and complied with the following summarized practices:

- Students entering the program take a placement examination based on their content, task, and textual focus, except beginners and L1 speakers of German.

- Assessment is linked to curricular goals and instructional practices.

- The assessment criteria should be clear and have a robust developmental character.

\footnotetext{
${ }^{31}$ Byrnes: 2011, APPENDIX 8A: 156-57
} 
- Multiple assessment sources, such as quizzes, midterms, final examinations, and individual and group projects, include planned or unplanned, individual, or group conditions.

- Ongoing course-based and final assessment combine three aspects: (a) a criterion reference for the overall course and curriculum goals; (b) an individual reference that focuses on student's personal goals within the general course goals, over a semester; and (c) an individual grade for the students' level of interaction in their German studies.

- Assessment results are communicated to students beyond merely scores or grades. Instead, meaningful feedback is conveyed.

- Assessment also serves as the base for the assignment of grades and acts as proof of language development and abilities.

- The semester final assessment for levels I-III in both intensive and non-intensive tracks is created by all teachers.

- As a result of the process approach to learning and assessment, student performance is assessed implicitly over the semester.

- All teachers from the department collaborate to create guidelines, administer tests, assess students' performance, and share information about test results.

- These assessment policies will be subjected to revisions to identify which ones are not accomplishing the intended goals. 
- The department will make every effort to ensure that all teachers "are knowledgeable about assessment within a content-based and task-oriented curriculum." (Byrnes: 2011, APPENDIX 8A: 157).

In my study, another vital element of learning that should be incorporated would involve a clear Harkness goal for students to become active and independent learners.

\subsection{Data collection of Meaningful Writing Exercises}

The study outlined in this section examines a corpus written in Spanish of 14 Baseline essays, and 14 Prototypical Performance Tasks essays from the same class to measure their progress over the Spring 2016 semester of instruction at the Florida State University abroad Valencia program in Spain. It is also a presentation of a research study of end-ofyear writing assessment across two classes of students of the same level. One group followed the genre-based approach, and the other continued with the traditional additive grammar approach. They were all screened for initial proficiency for the first time in this program. Because previous research (Huebner, 1995) has shown that studying abroad tends to amplify variation among individuals, finding individual differences was anticipated and taken as an invitation to further inquiry.

Seventeen students were female, and six were male. The corpus of essays was analyzed to identify their schematic characteristics and possible shortcomings as comprehensible and effective writing pieces.

My study is based on viewing language as a resource because language rules on their own would not be able to generate sufficient meaning. 
TABLE 15: Assumptions of SFL and Traditional Grammar ${ }^{32}$

\section{Systemic Functional Linguistics}

\section{Traditional Grammar}

\begin{tabular}{|c|c|}
\hline Language as a resource for making meaning. & Language as a set of rules. \\
\hline Language form related to meaning. & Form unrelated to meaning. \\
\hline $\begin{array}{l}\text { Text makes meaning using language } \\
\text { resources in context. }\end{array}$ & $\begin{array}{l}\text { Written or spoken text as displayed sentence } \\
\text { grammar forms. }\end{array}$ \\
\hline $\begin{array}{l}\text { Relates language system to text and values } \\
\text { both. }\end{array}$ & $\begin{array}{l}\text { Values language rules (competence) } \\
\text { Rather than text (performance). }\end{array}$ \\
\hline $\begin{array}{l}\text { Language learning as extending resources for } \\
\text { making meaning in context. }\end{array}$ & $\begin{array}{l}\text { Language learning as acquiring } \\
\text { correct forms. }\end{array}$ \\
\hline $\begin{array}{l}\text { Evaluate text as making meaning with } \\
\text { resources in context. }\end{array}$ & $\begin{array}{l}\text { Evaluate correctness of form; judge } \\
\text { meaning independently from form. }\end{array}$ \\
\hline
\end{tabular}

The underlying premise is that students' writing is improved if they become aware of the range of text types within the PE genre.

The PPT essays were compulsory to get a final grade and they were collected at the end of the academic year, i.e., end of May. Many of the essays had at least five of the following errors at first drafts: register and appropriacy, problems related to vocabulary, subject-

\footnotetext{
${ }^{32}$ Hammond, J. \& Derewianka, B., (2001:186-93)
} 
verb agreement, articles, word order and syntax, faulty reference and pronominalization. As I was aware of the main errors in students' texts, we would first go over the sentences together to allow self-correction or other students, then we would revise/devise some grammar rules on the board, and finally, we would practice together with some exercises on the screen.

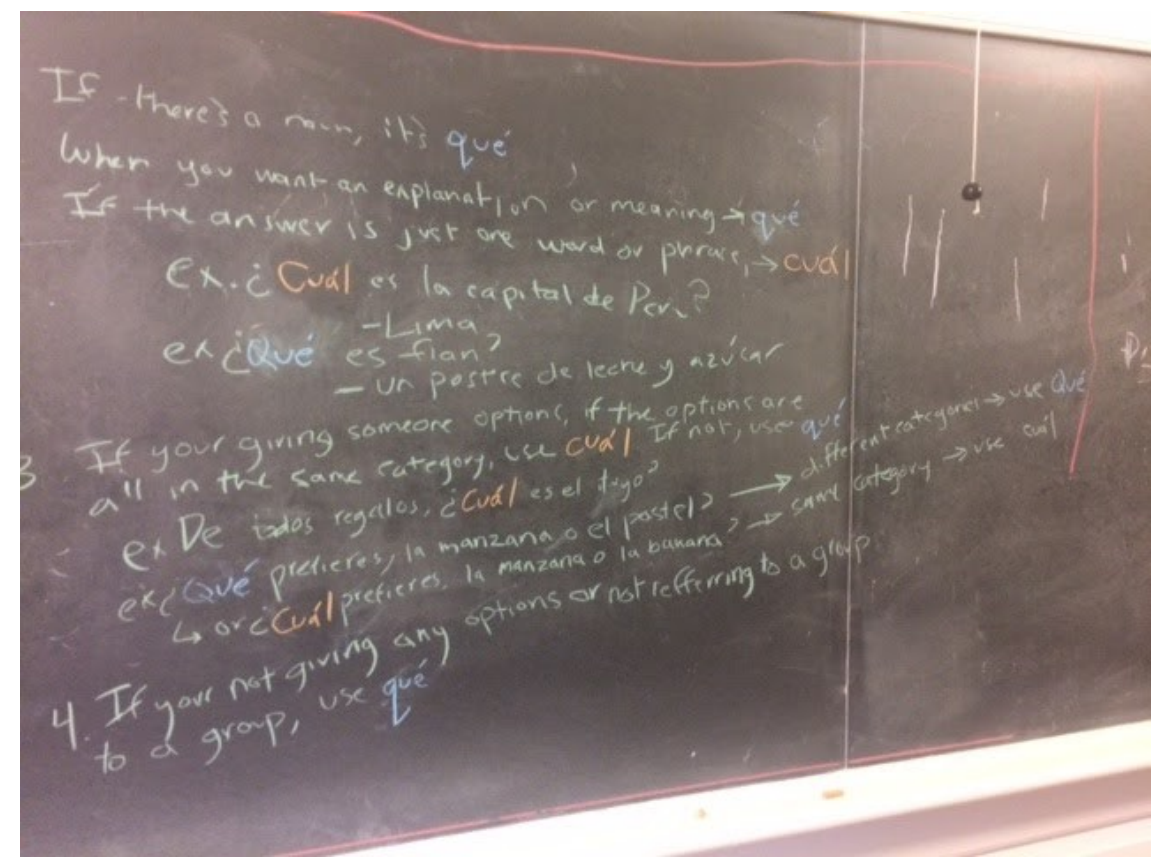

Figure 19: Students Qué/Cuál review uses at PEA 2019 Winter Term

Using SFL as the theoretical framework for the analysis of these texts allowed many insights because it offers instruments to analyze aspects related to form and content in any text as it concentrates on the idea of choice:

A systemic perspective focuses on choice, a relevant perspective as ESL (or any FL learner ${ }^{33}$ ) students are often unable to draw freely from the choices which exist in the English linguistic code for aligning language with the context in which it is used." (Ragan,1989:117).

\footnotetext{
${ }^{33}$ My emphasis
} 
The study investigates the degree to which one learning outcome, syntactic development/capacities in L2 writing, corresponded to curricular goals and expectations. Data from both learners' writing performances are presented. The fact that it showed significant gains in every instance is rewarding, adding another set of findings to the mounting evidence in favor of study abroad as an environment for language learning. However, arriving at these findings was considered as important to the success of the study as understanding and helping study-abroad participants by incorporating the Harkness methodology.

Without acquiring a rich syntactic capacity for putting lexicogrammatical facts together with a specific intention, the advanced textual abilities would not be achievable. The extent of language processing that can be captured within separate syntactic structures such as sentences and clauses was presumed in the curricular design to be significant indicators of learning development and outcomes described in the level profile for the course ${ }^{34}$.

There is a prominent element to the role played by the creation of word combinations, phrases, and sentences in language development for child L1 and adult L2 alike. Humans put words together in specific ways to enact meaning and doing so with increasing numbers and types of words.

The capacity to make choices about sentence construction depends on learners having developed specific core understanding about how syntactic elements can be and are combined in the target language.

\footnotetext{
34 Appendix 6A
} 
Developing writers' progress has been well-documented throughout the school years, especially in expository writing, as they gradually employ more complex and abstract vocabulary. (Berman \& Verhoeven, 2002). The use of abstract language such as nominalizations (words like 'destruction,' 'freedom,' 'perceptions,' and 'assimilation') is often mentioned as they increase with age. Writers in grade 5 are more aware of the discourse forms of different genres by using more diverse vocabulary in their persuasive essays $^{35}$. The number of subordinate clauses increases as writers gain more experience. Prior studies note that the number of complex noun phrases, among other syntactic skills, increases from age 9 to 12 years, and especially from age 16. (Ravid \& Berman:2010 In Segers E. \& van den Broek, P.:2017:124).

As the communicative demands in any language classroom increase, developing writers must acquire lexical skills and morpho-syntactic skills to include multiple ideas into fewer sentences.

Following Ortega's study from 2000 , I established critical values of 4.5 or more words per sentence, two or more words per T-unit, and slightly over one word per clause as the average between-group differences to be able to provide one set of benchmarks that can translate into curricular and assessment guidelines.

In addition to interpreting syntactic development, a minimum of the combined use of 3 measures selecting different qualities: overall T-unit length, clause length, and clauses per T-unit, were taken ${ }^{36}$.

\footnotetext{
35 Olin Olinghouse \& Wilson (2013) in Mackenzie N. M. \& Daffern T. (2020), Ch. 7. Teaching Writing: Effective Approaches for the Middle Years. (2020). United Kingdom: Taylor \& Francis. 36 Recommended by Ortega in 2002 when she studied a group of collegiate L2 Spanish writers on syntactic development. (Ortega, 2003)
} 


\subsection{Data Coding Methodology for Extracting Meaningful and Reliable Observations from the Learners' PPT Writing Performances.}

The coding for several features of syntactic complexity was converted into measures, and on their basis, various techniques were used for drawing comparisons.

The choice to focus on writing performance was intentional because I believe that linguistic knowledge about syntax does not reflect significant learning improvement, whereas the ability to communicate effectively in some genres does. Because the goal was to understand learners' syntactic complexity along the same level course, data had to be collected at the end of each instruction semester.

This study's population consisted of all undergraduate learners within the Spanish program who were studying the level II of the first year of the curriculum.

In addition, data from the highest level of language learning from undergraduates at $\mathrm{SAC}^{37}$, with the same number of students in a class, at a home university context, was examined at the end to find out the highest possible proficiency level that could be achieved following the same instructed method.

To illustrate that from the beginning of language teaching SFL can be applied, I have also included data from analyzing writing tasks of level I at PEA ${ }^{38}$ with a small number of students and all-inclusive Harkness pedagogy. I could not compare it with other sections of the same timeline because Spanish teachers at this level did not believe in starting writing instruction this early. Other language classes that I observed, especially French, did initiate it from elementary sections.

37 Saint Anselm College, Fall 2018, Manchester, NH, USA.

${ }^{38}$ Phillips Exeter Academy, origin of the Harkness pedagogy, Winter Term 2019, NH, USA. 
TABLE 16

Number of Data Samples by Level and Track

Curricular Leve

Prototypical

Both

Writing Task ${ }^{39}$ Performance Task ${ }^{40}$

Harkness

Level II

FSU 14

14

28

Non-Harkness

9

Level III-IV

SAC

15

Level I

PEA

12

Total

64

\section{TABLE 17}

Number of longitudinal Data Samples on the PPT

Curricular Level II

PPT

28

\footnotetext{
39 BWT

${ }^{40}$ PPT
} 


\section{TABLE 18}

Number of Cross-Sectional Data Samples on the Prototypical Performance Task (PPT)

\section{Curricular Level PPT}

Level I

Level II

Level IV
12

9

15

Total $\quad 36$

Note. samples reflect different starting and ending points for varying learners over the 1 and a half year of data collection.

The language focus portion of the assignments included complex sentence structures and accurate word order rules. Learners were directed to make the most of their abilities in producing this syntax, as called upon by the targeted genre's conventions. Also, each task was designed to elicit writing performances that I thought would reflect their best abilities.

I also introduced a second task into the study, the so-called Baseline Writing Task (BWT), to be collected at the beginning in a single writing session to extract their writing abilities and syntactic patterns. Learners were given 40 minutes to write and were encouraged to do the best they could with the content knowledge and language resources they had. The BWT was a generic writing task used in assessments of learners while the Prototypical Performance Task was relevant to the curriculum, taught with the Harkness pedagogy, and intended to elicit the maximal writing performance at this level. 
As a consequence of the process, a reasonable amount of data was gathered from students who completed both the PPT and the BWT during the same semester, enough to enable initial comparisons on the quality of language elicited between the two task types:

For the BLW Track 1: 814 words were produced in 14 student performances.

For the PPT Track 1: 1974 words were collected in 14 student performances.

For the PPT Track 2: 486 words were collected in 9 student performances.

To make a trustworthy interpretation of the results, it was necessary to find a method of extracting observations from the writing data ${ }^{41}$. The actual syntactic complexity was measured through direct coding and analysis of the data, and several primary features of learner syntax were targeted. First, the average number of words in a sentence provided the best global indicator for students' changes and differences.

The next step was the coding and analysis of the writing by segmenting data into T-units ${ }^{42}$ to provide a consistent fundamental analysis unit. Then there was a need to measure what was occurring below the sentence level, as learners created clauses of different types and lengths.

${ }^{41}$ Following recommendations by Ortega (2003)

${ }^{42}$ A T-unit is an independent clause together with all its dependent, subordinate and embedded clauses, see Hunt, 1965. 
EXAMPLE 1: a sentence produced by a learner in Level II from a first journal exercise:

T-Unit 1

T-Unit 2

El primer día, nosotros fuimos a Córdoba y el autobús tardó cuatro horas.

The first day, we went to Cordoba and the bus took four hours.

EXAMPLE 2: from the same student Level II PPT, One Multi Clause T-unit:

Cuando era joven mis padres se divorciaron, así que solía ir a la escuela en Pensacola con mi madre y viajaba a Jacksonville en el verano para visitar a mi padre.

When I was young my parents divorced, so I used to go to school in Pensacola with my mother and I would travel to Jacksonville during summer, to visit my father.

Next, data was further segmented into clauses for additional syntactic pattern measurements. Each clause was also categorized according to type: dependent nominal, adverbial, relative, and coordinated independent clauses. The development of syntactic complexity reflects both the combining and the lengthening of clauses. (Norris \& Ortega, 2009)

The Linguakit ${ }^{43}$ Syntactic sentence analyzer tool was applied in conjunction with a Mystylus $^{44}$ feature that creates a visual representation of the syntactic structure through tree diagrams. Linguakit focuses on the automatic analysis of the syntactic relationships that are established between the pairs of words that compose it: its type of dependency relation, which word is nuclear and which is dependent, its grammatical category, and its position in the sentence. When you enter a text, it results in a dependency syntactic analysis for each writing sentence.

\footnotetext{
${ }^{43}$ Cilenis Language Technology

44 https://www.mystilus.com/herramientas/analizador-morfosintactico
} 


\section{EXAMPLE TRACK 2}

TRADITIONAL GRAMMAR FOCUSED INSTRUCTION

-Preliminary Analysis PPT

Escribe sobre ti (biografia). 40 palabras.

Me llamo Trina. Tengo veintiund años.

Soy simpatica, extrovertida, trabajadora, organizada

y honesta. Soy de Florida. Nací en Tampa pero

mis padres son de Vietnam. Nací en 1995.

Crecí en Tampa, tambien. Este verano, estoy estudiando en Valencia. Me gusta mucho.

5

\section{Estadísticas}

Número de nombres

$3 \quad$ Número de adjetivos

4

Número de verbos

$8 \quad$ Número de adverbios

2

\section{Frecuencia de categorías}

Número de frases

Número de palabras

Número de lemas

diferentes
$9 \quad$ Variedad léxica

$55 \quad$ Número de caracteres

$35 \quad$ Caracteres sin

espacios
$89.474 \%$

261

221

Sentimiento NONE $0 \%$ 


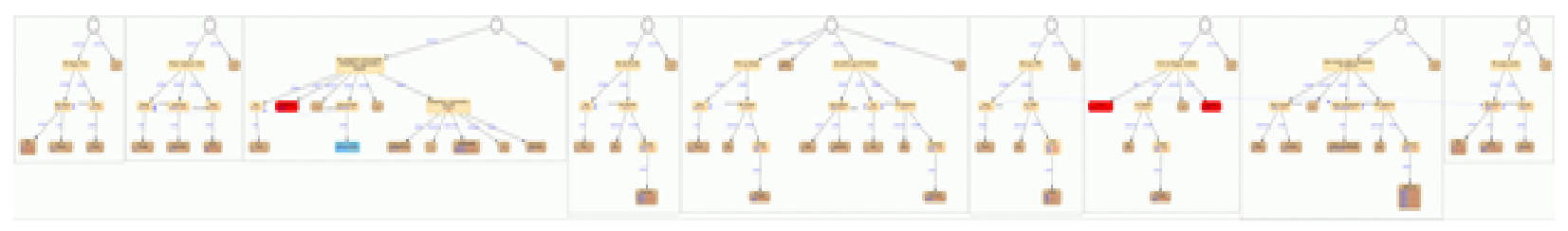

\section{EXAMPLE TRACK 1 PPT}

\section{MULTI-CLAUSE SENTENCE}

"Cuando era joven, mis padres se divorciaron, así que solía ir a la escuela en

Pensacola con mi madre y viajaba a Jacksonville en el verano para visitar a mi padre."

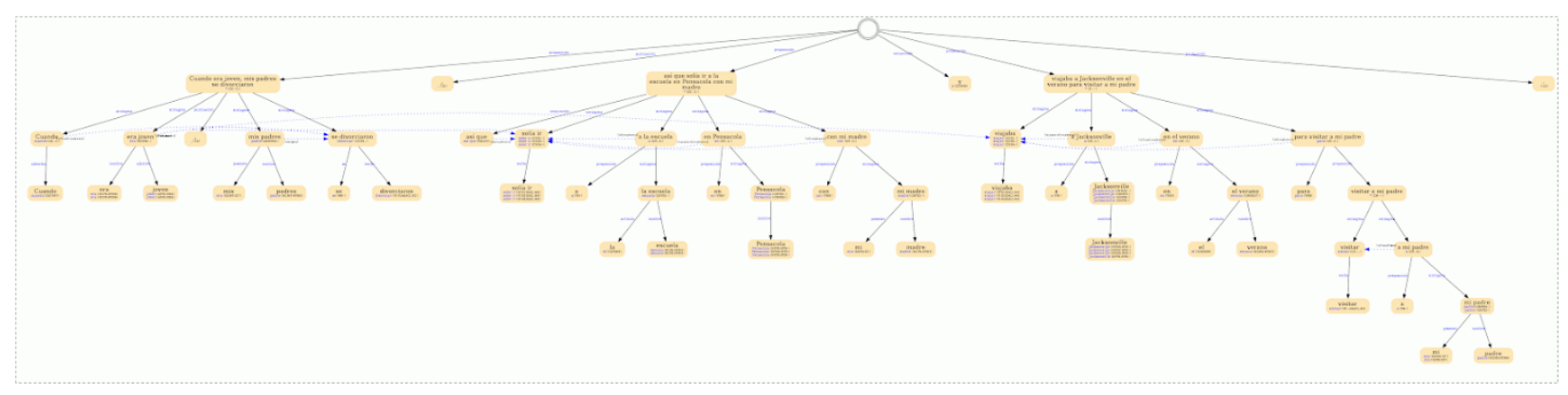

"When I was young, my parents divorced, so I used to go to school in Pensacola with my mother and I would travel to Jacksonville during the summer to visit my father."

${ }^{45}$ https://www.mystilus.com/tmp 2020/mystilus-1587727788yGPTdx.png 


\subsection{Data Analysis Report, On Errors}

\section{STUDENTS}

Some of the main problems I found in their essays were connected with word order and syntax (a common mistake among Anglo-learners) because students tended to write following the syntactic order that they found in their mother tongue and were not familiarized with the main syntactic patterns of the Spanish SVO language yet. The position of adverbials, for instance, or sometimes new information was in the imprecise position (at the start of the sentence) as we can see in these examples:

-A variety of open markets during the week in the city are taking place to solve the recently closed Mercado Central in Valencia. This sentence might be effective if the purpose is to emphasize the variety of open markets, rather than the solving of a problem.

-Many women from Rumania are coming to work in the Basque Country farms, where the new information is at the end of the sentence.

With phrases like these, I could describe to students theme, which usually coincides with known information, and rheme found at the starting point with new information or comment. Teachers could guide students to see how in good essay writing, new information is often presented at the end of one sentence and mentioned at the beginning of the next. (Martinez L. 2006:148)

There were some errors with vocabulary use: learners have to be mindful of certain words that have similar forms to words in their language, but the meaning is different; for example, library does not mean libreria in Spanish (libreria means bookshop); constipate 
does not mean constiparse (constiparse means to get a cold), and to be embarrassed is not estar embarazado which means to be pregnant in Spanish! There were omissions of words, especially prepositions, and a common error like particles in phrasal verbs. Finally, I have found students have difficulties with the subject-verb agreement: it is quite common to detect a plural subject with a verb in singular or vice versa, i.e., a subject in the singular form with a verb in plural, as we can observe in these examples:

S1: Cada verano me han (he ido) ido en (de) vacaciones con mi familia. El verano es mi favorito parte (parte favorita) del año.

S2: Nos qustabamos (gustaba) ir en el (al) océano para nadar y "surf" (surfear).

S3: En los domingos, mi familia y yo salimos (de) nuestra casa para (la) iglesia muy pronto por que (porque) las personas de nuestra iglesia hablaban mucho.

When the instructor uses authentic texts as models for writing, and the students are asked to write for authentic purposes, you can work more effectively to correct such errors. Using SFL in the classroom highlighted the written text as a purposeful and interactive communication. 


\section{DATA}

In this study, to minimize possible human miscounts so that measures based on data coding could be interpreted with accuracy, all data was recorded and tracked through the computerized system Linguakit.

Linguakit is a linguistic resource for researchers. RedEmprendia ${ }^{46}$ incorporated this new tool targeting students, researchers, professors, publicists, and companies. It is one of the most complete linguistic resources in Spanish, Galician, Portuguese, and English available on the web, and is designed to help users improve the quality of their writing, analyze the language, and obtain necessary information from any text. A Full Analysis option provides the number of words and phrases of a text and its kind. It offers a summary and its assessment. A Syntactic Analyzer will result in a complete analysis of the syntactic relations established between the pairs of words that compose it: its type of dependency relationship, which word is nuclear and which is dependent, its grammatical category, and its position in the sentence. It facilitated the subsequent work of identifying T-units, clauses, and clause types and converting this data to estimates of complexity and descriptive statistics for each learner.

${ }^{46}$ Developed by the Galician spin-off Cilenis of the University of Santiago de Compostela (USC) 


\subsection{Comparative Study of Baseline Writing Tasks and Prototypical Performance Writing Tasks Answering Question 1.2 Do syntactic patterns match the expectations of the curriculum?}

My purpose as a teacher in the Spanish program was to make sure that students saw writing as a way of communication. Throughout the academic year, I emphasized the writing process. Students were not used to being given a topic in a Spanish language class. The first step was to start reflecting writing by presenting the stages of the writing process: prewriting, drafting, revising, and editing. The objective was to persuade students that in the drafting and revising stages, they can pay attention to errors related to vocabulary, particles, subject-verb agreement, and articles because, in many cases, a revision implies self-correction.

By doing so, the students understood the creation of writing as a process, not a product, and that writing good texts needs some degree of organization and planning.

For this reason, I wanted students to be aware that it was impossible to obtain a good result without following the process: it is unreasonable to eliminate one or the other. As a Baseline Writing Task, my students (Track 1) wrote a diary of their latest four-day trip in Spain. They had to write 4 to five sentences for each day's activities and the task was taken at the beginning of the semester. I analyzed their Mean Length per T-Unit and number of subordinate clauses as a marl of syntactic development. 


\section{Track 1. Instructed Writing}

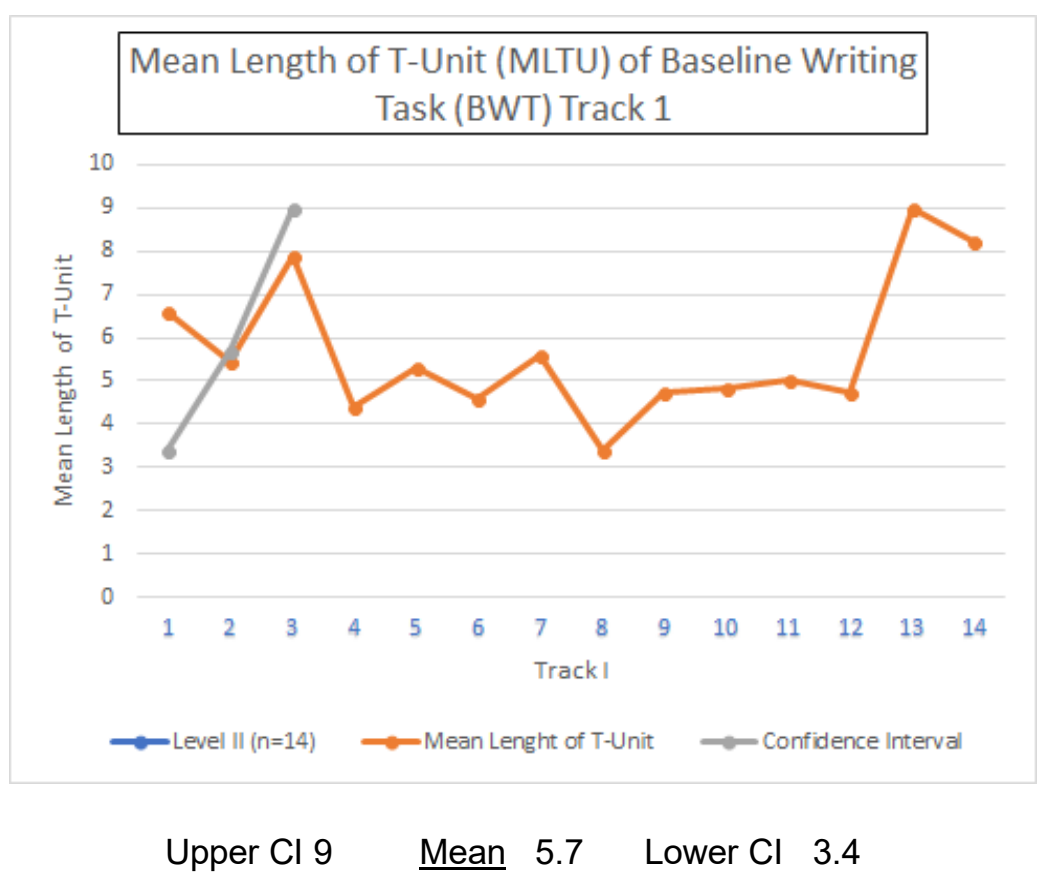

Figure 20: Analysis of BWT T1

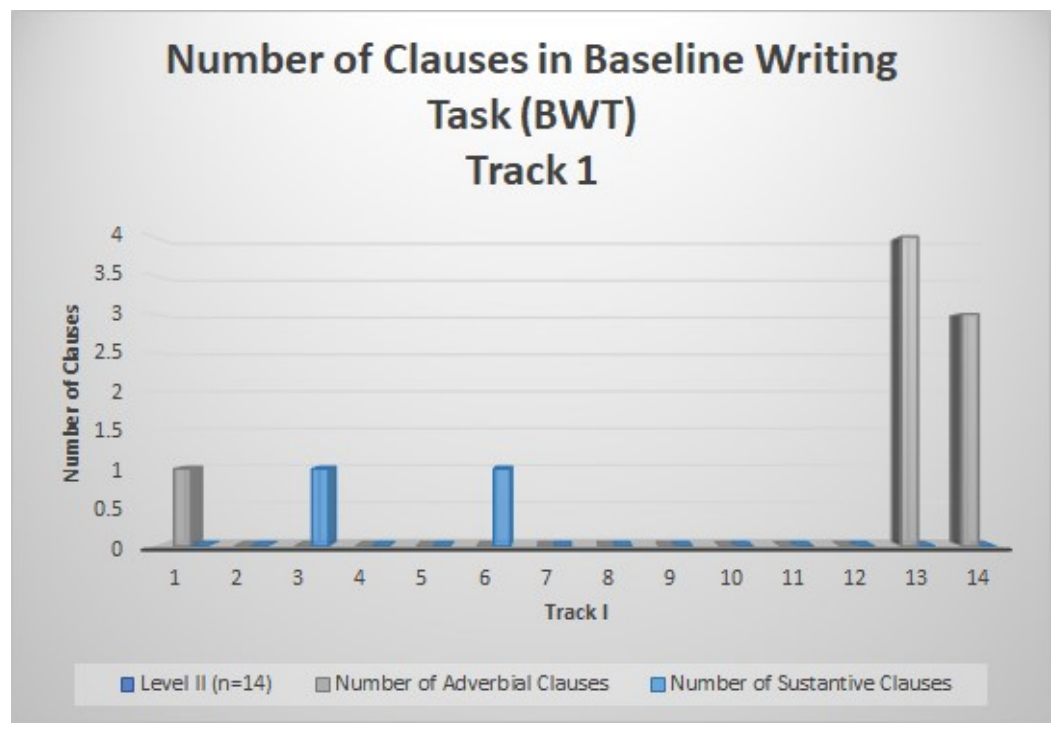

Figure 21: BWT Number of Clauses per student T1 
The Baseline Writing Test showed minimal writing proficiency after a year of Spanish at university level. Student n.13, 14, and 3 wrote longer T-Units and included more subordinate clauses. The rest had a very basic (as generally expected at their traditional grammar-focused university level) ability of making meaning of the text form given (diary) as their language resources were minimal. After six months of instructed writing the improvement was obvious:

Answering Question 1.2 Do syntactic patterns match the expectations of the curriculum?

\section{ANALYSIS OF PROTOTYPICAL PERFORMANCE TASKS T1}

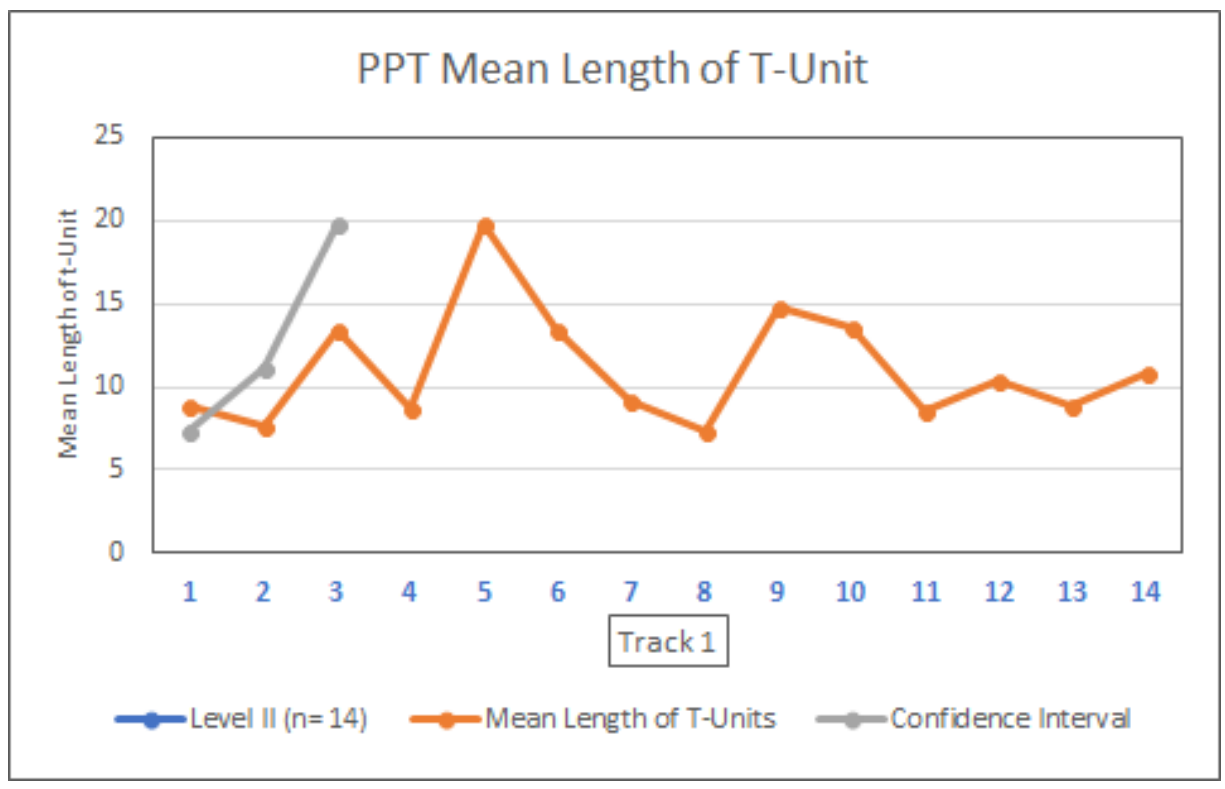

Upper Cl 19.8 Mean $11.02 \quad$ Lower $\mathrm{Cl} 7.42$

Figure 22: PPT Mean Length of T-Unit T1

The mean of T-Units of the whole class almost doubled from 5.7 in their Baseline Writing Task to 11.02 in their Prototypical Task. For student n.5 the new pedagogical method really worked, his MLTU went from 5.1 to the upper C.I 19.8. I then compared both tasks from all students within six months. 


\section{Results Of the Study in Instructed Written Class Track 1 ANALYSIS OF BOTH TASKS T1}

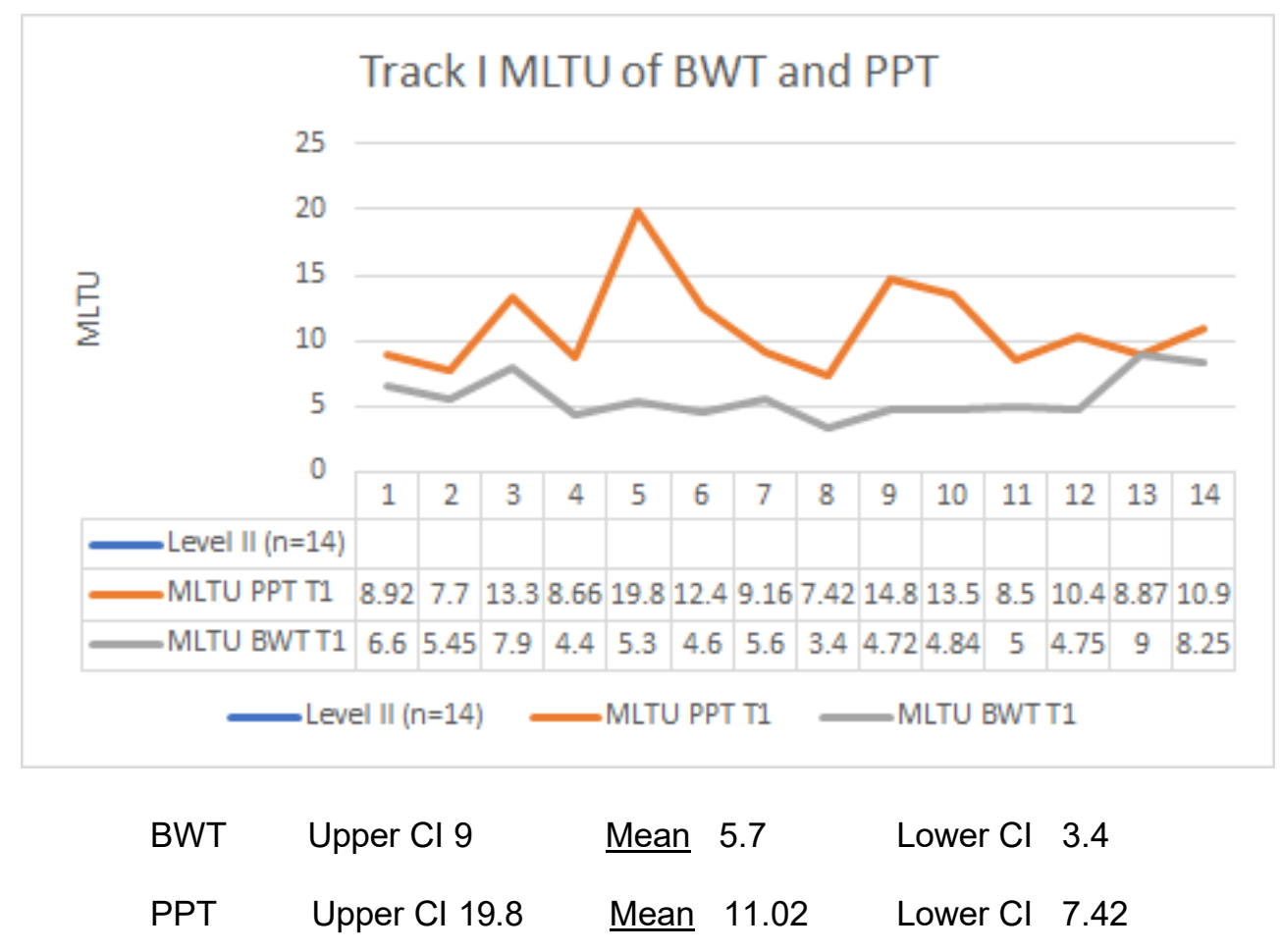

Figure 23: T1 BWT and PPT

Here you can see their individual progress across the semester. Student n.13 started at the highest proficiency and stayed the same. Either she plateaued or I suspect that realizing her advantage laid back and ended up being at the (final higher) bottom of the class. 


\section{Results Of the Study in Grammar-Focused Class Track 2}

Next, I examined the Prototypical Performance Tasks from the class in the same semester (Track 2) that received a traditional grammar-oriented and cumulative teaching.

Track 2 Non-Instructed Writing

ANALYSIS PPT T 2

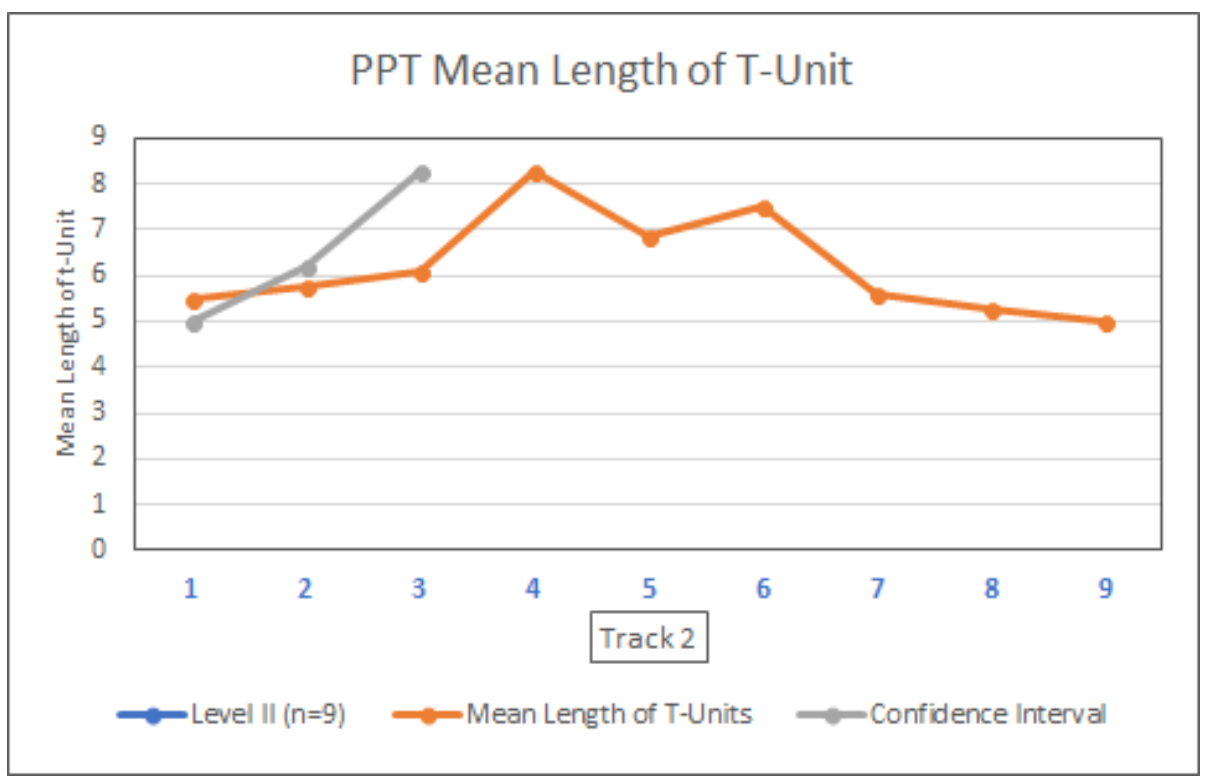

Figure 24: PPT Mean Length of T-Unit Upper $\mathrm{Cl} 8.3 \quad$ Mean $6.2 \quad$ Lower $\mathrm{Cl} 5$

Their total mean length of 6.2 was very close to the mean length of my class' Baseline Writing Task of 5.7. All students at this level were assessed at the beginning of the semester and they chose their class according to their individual schedules. Although I did not get a BWT from the class in Track 2, looking at their first written test where they attempted to write some sentences, their level was almost identical to my students. Their writing development along the semester was nominal. 
In answer to research question (3) How proficient can students become when surrounded by best learning conditions, such as the Harkness method and small class numbers, when introducing genre-based writing tasks throughout the duration of a language course?

\section{COMPARISON OF RESULTS OF THE STUDY IN BOTH TRACKS}

The comparison between both tracks showed the gap in proficiency from the different pedagogies of teaching and learning.

\section{ANALYSIS PPT T1 and T2}

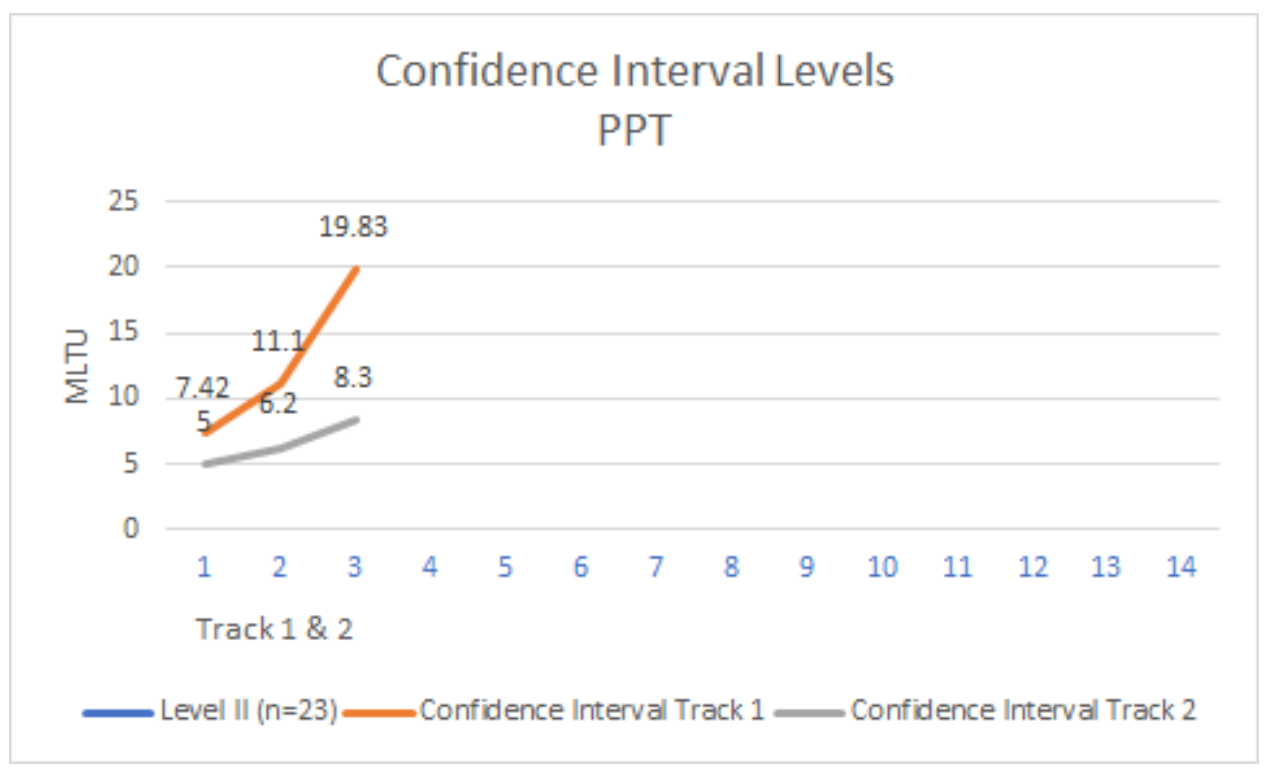

Figure 25: Confidence Interval of both Tracks 


\subsubsection{Further Comparisons of PPTs from Two Different Instructional Routes: Genre-Instructed Class vs. Traditional Grammar-Focused Instruction on the Same Level.}

Syntactic development in L2 writing

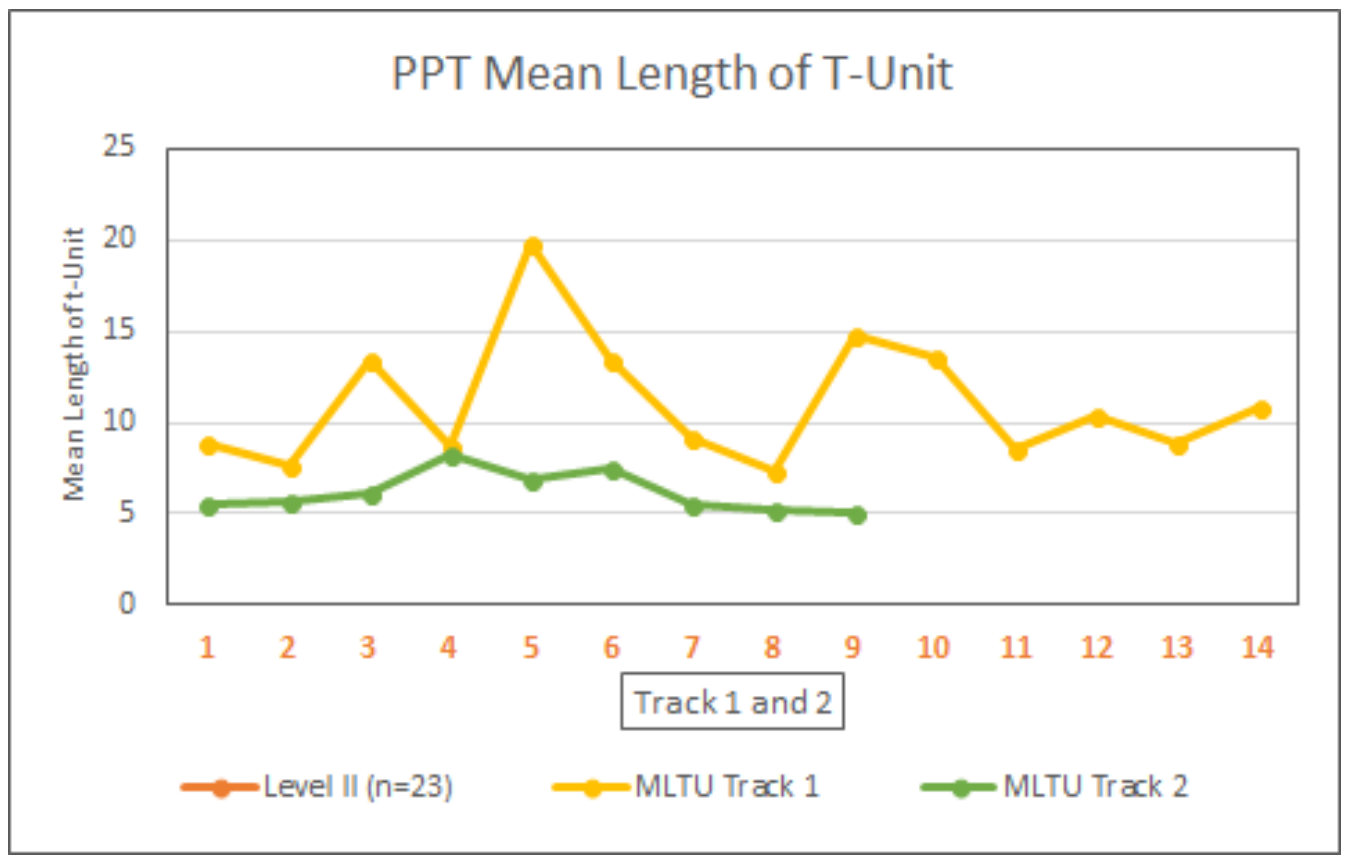

Figure 26 shows that learners of Track 1 produced longer T-units and more clauses than Track 2 students.

T1 PPT: Upper Cl 19.8 $\underline{\text { Mean }} 11.02 \quad$ Lower Cl 7.42

T2 PPT: Upper Cl $8.3 \quad \underline{\text { Mean }} 6.2 \quad$ Lower $\mathrm{Cl} 5$ 


\section{Answering question 1.3 Do syntactic patterns match the expectations of the curriculum? Correspondence to Curricular Statements and Outcomes Expectations}

In the curriculum, and in general, it seems, syntax is a multivariate construct that calls for at least several measurement perspectives in order to reveal actual development. Considerable development occurs during the level II transitional stage, as learners move from initial exposure of Spanish to the demands of using it in relatively sophisticated ways. (Norris \& Ortega, 2003, 2009); (Ortega, 2003).

My Spanish courses' level II-III with Instructed Writing Teaching gained higher MLTU of all, but lower CTU and MLC than Level I PEA and SAC III/IV students.

The Spanish Level III-IV that I taught at SAC achieved higher MLTU than level I at PEA but less than level II FSU and higher CTU and MLC than Level I-III of the other two.

Table 19 that follows connects the Course Design and Language Focus, the Prototypical Performance writing tasks with the Syntactic Complexity Development outcomes. 
Table 19 Levels I-IV

Course Design, Prototypical Performance, and Syntactic Complexity Development

\begin{tabular}{|c|l|l|l|}
\hline Level & Language Focus & $\begin{array}{l}\text { Prototypical } \\
\text { Performance } \\
\text { Writing Task }\end{array}$ & $\begin{array}{l}\text { Syntactic } \\
\text { Complexity }\end{array}$ \\
\hline I & $\begin{array}{l}\text { At or below } \\
\text { sentence level. } \\
\text { Major syntactic } \\
\text { patterns of simplex } \\
\text { sentences. } \\
\text { Initial exploration of } \\
\text { subordination. }\end{array}$ & $\begin{array}{l}\text { Personal Essays } \\
\text { Chronological } \\
\text { narration. } \\
\text { Expression of time } \\
\text { relations and cause- } \\
\text { effect via coordinate } \\
\text { or subordinate } \\
\text { adverbial, } \\
\text { Substantive and } \\
\text { Adjective clauses. }\end{array}$ & \\
\hline II/III & $\begin{array}{l}\text { Complex sentence } \\
\text { for expressing } \\
\text { chronology, } \\
\text { cause/effect, } \\
\text { comparison \& } \\
\text { contrast with many } \\
\text { coordinating T- } \\
\text { Units. }\end{array}$ & $\begin{array}{l}\text { Personal Essays. } \\
\text { Journals. } \\
\text { Narration beyond } \\
\text { simple chronology. } \\
\text { Description of people } \\
\text { and places. } \\
\text { Expression of cause- } \\
\text { effect and } \\
\text { comparison-contrast. }\end{array}$ & $\begin{array}{l}\text { Higher MLTU of } \\
\text { all, but lower } \\
\text { CTU and MLC } \\
\text { than Level I PEA } \\
\text { and SAC III/IV } \\
\text { students. }\end{array}$ \\
\hline III/IV & $\begin{array}{l}\text { Expertise with } \\
\text { subordination. }\end{array}$ & $\begin{array}{l}\text { Personal Essays. } \\
\text { Presentation, } \\
\text { comparison, and } \\
\text { contrast of processes } \\
\text { and qualities via } \\
\text { complex } \\
\text { subordination. }\end{array}$ & $\begin{array}{l}\text { Higher MLTU } \\
\text { than level I PEA } \\
\text { but less than } \\
\text { level II FSU. } \\
\text { Higher CTU and } \\
\text { MLC than Level } \\
\text { I-III of the other } \\
\text { two. }\end{array}$ \\
\hline & & & \\
\hline
\end{tabular}


Answer to Question 3.1 Do learners in different educational settings with an SFL educational approach generate complex syntactic writing as well? Comparison with Other Spanish Foreign Language Contexts

Finally, it was important to compare my results with other instructed language learning contexts at Saint Anselm College during the Fall of 2018 for the same amount of time and at Phillips Exeter Academy for approximately half of a semester in their winter term of 2019. The average high school GPA of the admitted freshman class at Saint Anselm College was 3.22 on the 4.0 scale, indicating that primarily B students are accepted and ultimately attend. The average high school GPA of the admitted freshman class at Florida State University was 3.88 on the 4.0 scale, indicating that primarily Astudents are accepted and ultimately attend. At PEA, two essays, counselor, English and math recommendations, testing of SSAT or ISEE, and two previous year transcripts are required.

For the PPT Level I at PEA: 1562 words were collected in 12 student performances.

For the PPT Level III-IV at SAC: 3114 words were collected in 15 student performances. 


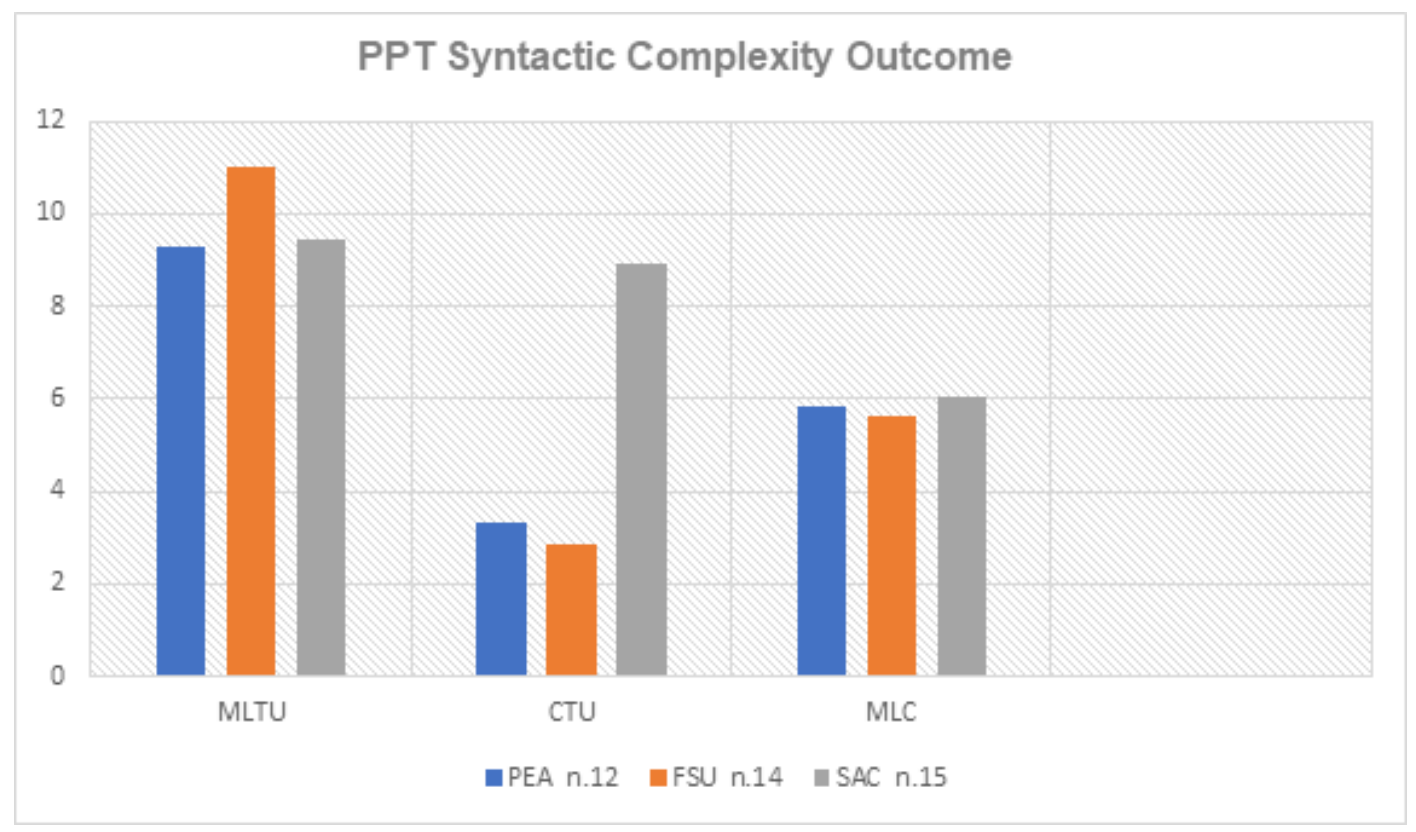

Figure 27: PEA, FSU and SAC PPTs Comparison

At first glance FSU developed a higher MLTU but less Clauses per T-Unit. SAC's students on the other hand produced the highest number of subordinate clauses indicating a greater proficiency development. The Mean Length of Clauses were very similar for all three levels. Table 20 includes the precise numbers after examining the results from the three educational institutions. 


\section{Table 20}

Comparison of Syntactic Complexity Outcomes on the FSU PPT with SAC and PEA

\begin{tabular}{|c|c|c|c|c|}
\hline Measure & Institution & Level I & Level II & Level III-IV \\
\hline MLTU & PEA & 9.29 & & \\
\hline & FSU & & 11.02 & \\
\hline & SAC & & & 9.4 \\
\hline MLC & PEA & 5.83 & & \\
\hline & FSU & & 5.61 & \\
\hline & SAC & & & 6.06 \\
\hline CTU & PEA & 3.33 & & \\
\hline & FSU & & & 2.85 \\
\hline & SAC & & & 8.93 \\
\hline
\end{tabular}

Measures: MLTU=Mean length of T-unit, MLC=Mean length of clause, CTU=clauses per T-Unit. 


\section{CONCLUSIONS}

8.1 Research Question 1: How do college-level American FL writers develop their genre awareness, linguistic knowledge, and writing competence in a systematically designed genre-based writing course that incorporates personal essays/nonfiction writing tasks?

\section{The specific focus, a worthwhile contribution}

Persuasive writing requires several things, such as a careful choice of vocabulary, grammatical patterns, and sentence structures to create a style appropriate to the subject matter and the eventual readers. A high degree of organization in developing ideas and information and drawing on complex grammatical devices for focus and emphasis is also imperative.

Since language is a resource that can be used in different ways depending on what we want to achieve in a particular context, students needed to be aware of the different cohesive devices and types of context. The revision of the writing process was also relevant so that they perceived the structure of the text needed to be planned in advance, and that this structure and the lexico-grammatical choices were not random because they depended on the subject matter and the genre type.

In my advanced Saint Anselm class, learners produced writing more on par with graduate students, offering validation for the efforts I spent with their curriculum development and assessment. 
Systemic functional linguistics (SFL) as a theory of how wording constructs meaning in a text, provided insights into learner development and the tools to analyze the processes of guided classroom assessment and teacher perception, which would otherwise go unidentified.

I have applied SFL to the analysis of texts in order to help students write better or more efficiently, and I did this in the language class as this is the place where individuals can experiment with communication. Having SFL as a framework to analyze students' texts allowed me to concentrate on the importance of planning information at text level and seeing the correspondence between form and meaning.

For integrated assessment of language and content (IALC), with particular reference to second language learning and use, this assessment can also serve, as I have shown, as a powerful tool to adapt students' needs more effectively.

It is of the utmost importance to give enough support, resources, and recognition to teachers pursuing a valid SFL analysis of meaning and wording to continue with this necessary work across all levels.

In response to evolving student demographics and expectations, to faculty dissatisfaction with certain traditions from the FL practice such as textbook only driven curriculum, and the desire and need to know the outcomes of student learning, the Modern Language Association concluded that "the arts of language and the tools of literacy are key qualifications for full participation in the social, political, economic, literary, and cultural life of the twenty-first century." (MLA, 2008:2) 
This study can answer the "how and what" of improved SLA with tools that can be utilized to achieve worthwhile participation developed from the very base of language instruction by a teacher and not through any external directive designs of reform.

\subsubsection{Benefits of Personal Essays Based Writing Focus}

It is analogous to travel planning. Our frameworks should provide a set of itineraries deliberately designed to meet cultural goals rather than a purposeless tour of all the major sites in a foreign country. In short, the best designs derive backward from the learnings sought. (Wiggins \& McTighe, 2005:14).

I propose that genre-based PE focus offers the means to advanced literacies and that it will add value to FL studies because writing, with its predominance across the academic and in the information economy, is highly sought. However, FL writing mastering should not be seen as only attainable by a few persistent and bright students. Based on my experience, writing provided a functional means for introducing learners from the very beginning to the interconnected essence of language and cultural content, helping them and teachers to view sophisticated goals and to pursue them right away.

For the students already literate in at least one other language, writing also provided an excellent medium for language creativity; it facilitated reflection, focused feedback, and revision both individually and in the classroom.

As far as the relevance of the Personal Essay for today's digitally native students, to perceive "Facebook as some sort of opponent to the PE when it could very well be an ally, and the same thing is sure of blogs: even as we speak, there are sharply written, well-shaped, self-aware blogs on the Internet, alongside self-indulgent diarrhea...Future personal essayists, brought up on Facebook, will undoubtedly notice different details from those we did, in any case, they will have no shortage of things to notice..." (Lopate, 
2013:130-31) Hopefully, they will continue to offer the little gems of truth that we PE lovers seek.

The course from the beginning treated language and cultural content through a common approach to genre-based writing development. It is an example of meaningful educational reform in Teaching Spanish as a Second Language. 


\subsection{Research Question 2: How does college-level American FL writers' proficiency final acquisition compare to the same college-level American traditional L2 learners' knowledge?}

Considering the number of clauses as an indicative of developed language proficiency the analysis of the results in both tracks of study undoubtedly showed that of the total of 23 students, the 14 in my class produced many more subordinate clauses.

Track 2 produced only compound sentences and no substantive or adverbial clauses. All students in Track 1 on the other hand incorporated adverbial clauses in their compositions and student $\mathrm{n} .1$ added a substantive as well.

The following is an analysis of Track 1 and 2 subordinate clauses which determines their final syntactic development in detail.

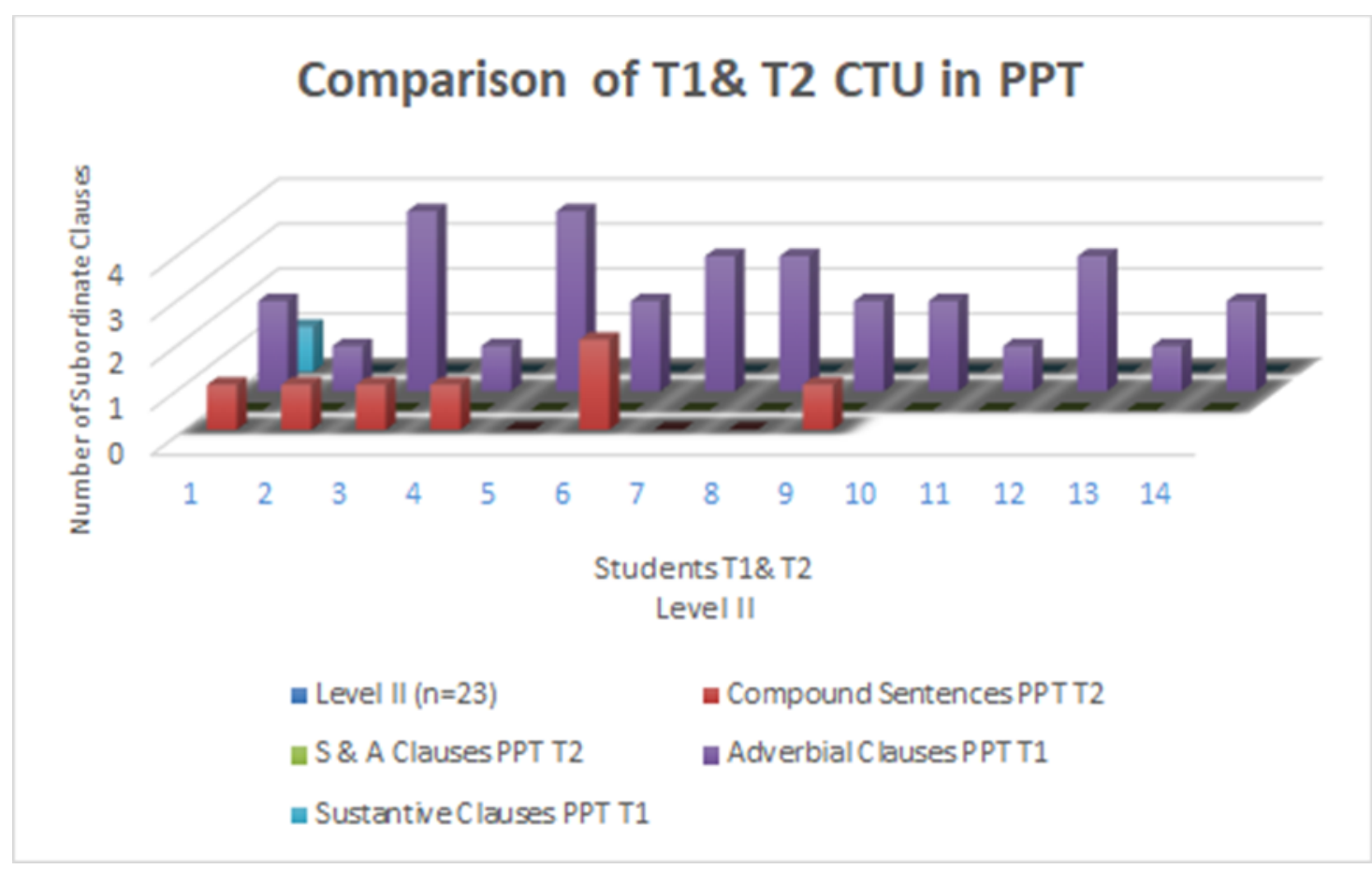

Figure 28: Number and Type of Subordinate Clauses in T-Units for T1 and T2 PPTs 
The emphasis for Track 1 was on moving away from the discussion of one's immediate surroundings toward the narration of events in different times and places that is, through their extensive exposure to personal narratives, students at Track I were becoming used to more extended syntactic units based primarily on greater subordination for the purposes of narration. Learners produced clearly more complex syntax in their first-draft writing and final revision, as measured by the T-unit length.

Over the beginning of intermediate sequences of instruction, subordination played a significant role in how students began to create longer sentences in their writing as they learned to piece together clauses into syntactical units.

The findings from the current study supported the intended curriculum, at least in promoting learners' development of syntactically complex structures and applying them in purposeful and genre-embedded writing.

On the whole, learners in the study exhibited substantial, even surprising, degrees of syntactic complexity difference/development over the semester under investigation. 
8.3 Research Question 3: How proficient can students become when surrounded by best learning conditions, such as the Harkness method and small class numbers, when introducing genre-based writing tasks throughout the duration of a language course?

The Harkness Method Significant Educational Contribution in Foreign Language Studies Education.

To learn from others' experience, to wonder how else to see it, (and) to recognize how one's own viewpoint is affected by culture and time and experience. (Hassan, 2015:124).

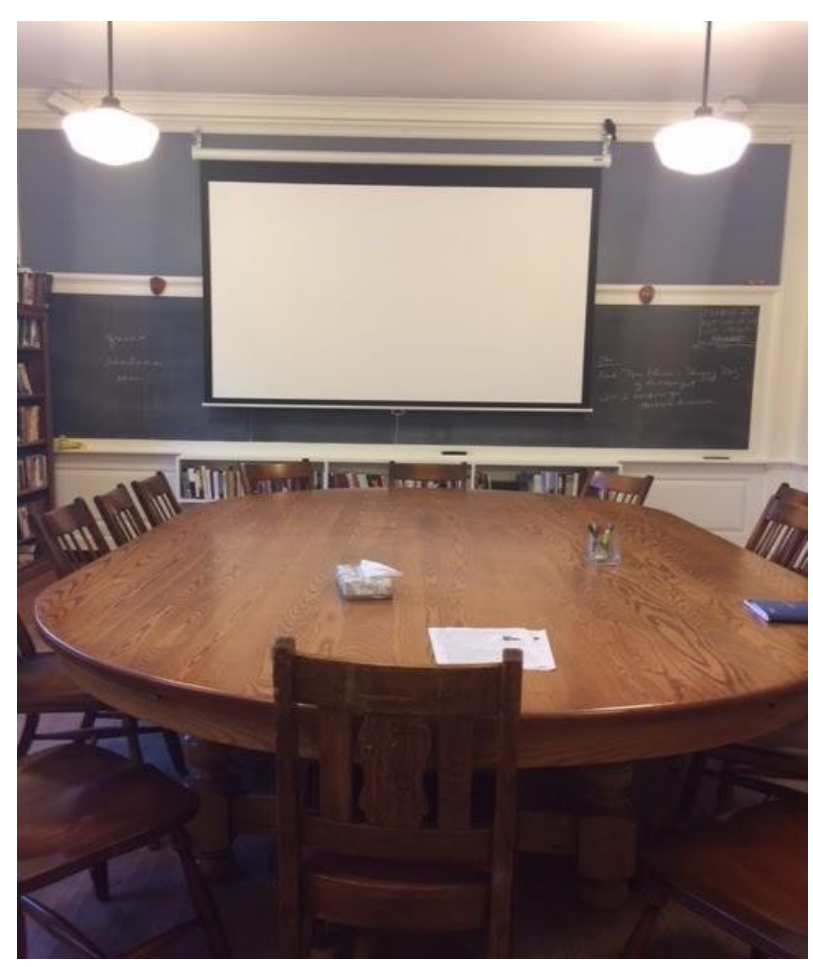

Figure 29: Harkness Table at PEA

From the beginning, storytelling is an integral part of language learning at PEA; they read, listen, and answer questions about stories. Hopefully, these actions eventually lead to learning to tell their own stories and discover something new about themselves and the target culture. Writing Personal Essays helped them reflect on their individual experiences 
that living in the Spanish language and culture generated, one of the main reasons that I was attracted to this pedagogy.

People that speak another language can distinctly express the same ideas, to use Spanish preterits is to become aware of a different time sequence and "to understand the Chinese characters for the word "remorse" it's to know more of what the word means...No word ever captures all what it represents, but to see different meanings in language is to become more aware of our culture and some else's." (Lomas:6)

An advantage of the collaborative learning process is that it motivates students to come to class prepared to work together and answer questions both orally and in writing as they acquired more proficiency and can become more creative in their work, teachers' role shifts from guide to facilitator. (Hassan, 2015:77).

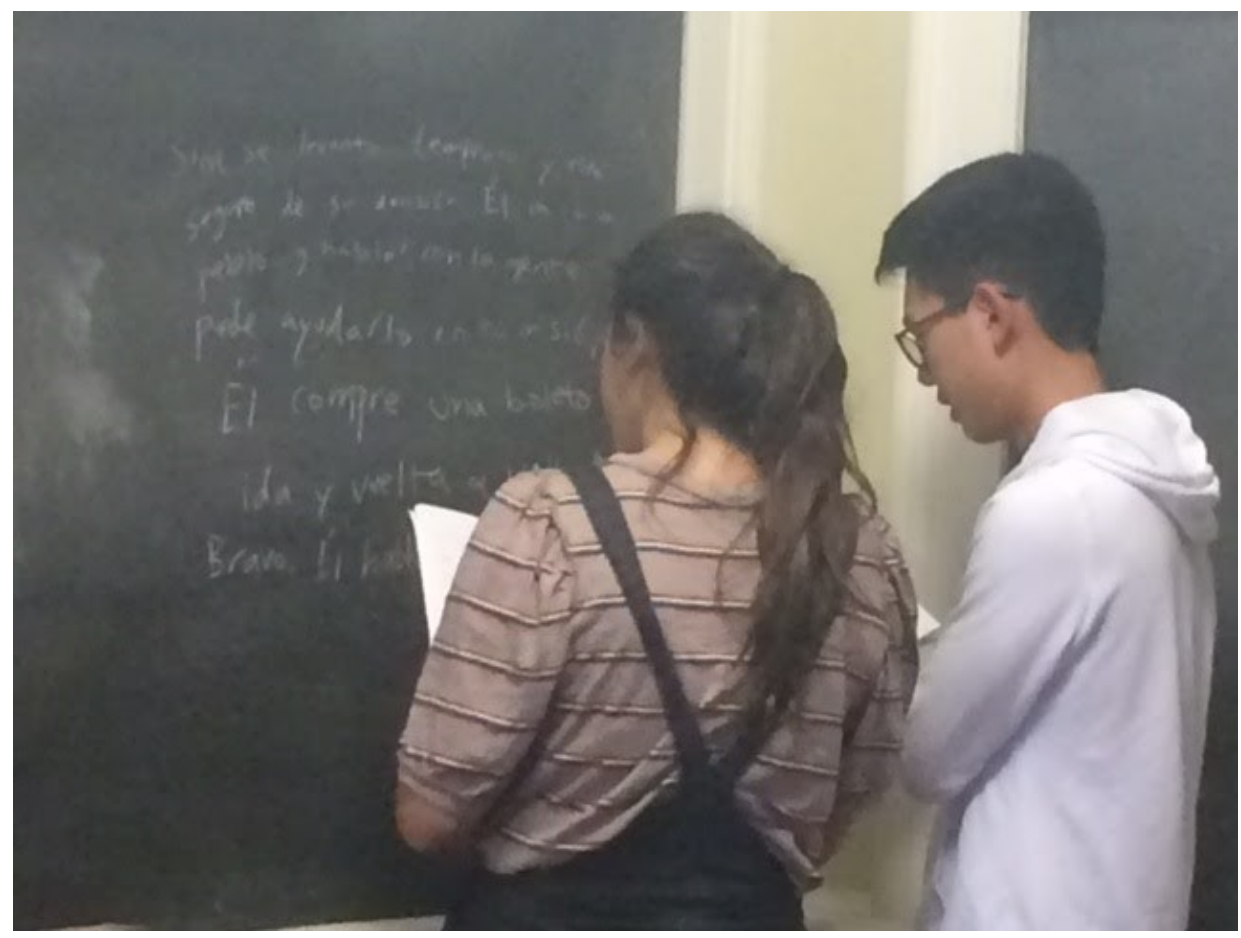

Figure 30: PEA students writing a summary of a story in my class. 
Students challenge the teacher to be more creative with an ongoing shared developed content in this discussion setting. With the Harkness method, I continued to lead by listening with respect and by encouraging participation. A fair conclusion can be derived from the course evaluations in that students knew my active involvement with the class and with their progress.

Even if at the introductory level the notion of the Harkness classroom is somehow impossible as students cannot learn as independently in a second language as they would like to, the language classes that I observed at PEA were unlike any traditional class because of their confident input and already higher language acquisition through writing.

Some teaching strategies that I learned from the Harkness methodology and applied later on:

-Harkness is not always a clean way to teach or learn. It would help if you shouldered on; benefits will show up in unexpected ways.

- When you are planning your course curriculum think about the final destination and plan accordingly. Do not share all of it with students so they can acquire this knowledge independently: "There is an art to finding the right balance between direction and freedom." (Heskel, 2008:118).

-Be patient when sometimes no progress seems to be happening, but when it does, let students own it. 
- My Spanish origins knowledge, not just the language itself, helped show patterns, and explained differences and commonalities between our languages. Instead of memorizing forms, they understood concepts that could be applied in ample ways. -The class size was essential for language work, the number of students was ideal, and it allowed a narrative discussion similar to a seminar setting.

-Playing games in Spanish in class, such as Slovin theatrical exercises, was a way later on for students to work and learn more from each other.

-Students who hesitated to participate in class during the first few weeks got comfortable later on with PE tasks that encouraged them to take pride in their work and not be afraid of different interpretations of the same topic. Shy, more reflexive students benefited enormously from the written tasks.

By bringing Harkness to college, I searched for a solution to the Spanish education abroad programs' frustrating situation. I was very disappointed not to offer a better and more fruitful experience for students in my own country, and I combined the Harkness pedagogy that I already knew, with advanced writing instruction based on the SFL theory. Students that have had a Harkness education in high school went to college and "often prove vastly superior to their peers in analytical skills and writing talents. They also tend to be extremely self-confident and well prepared." (Heskel:239) I wanted to bring those skills, qualities, and high standards to my class and guide them to learn from each other rather than feeding them with information.

Still teaching the way I see it, is a lifelong learning experience, and to "know when to add or remove your own voice from an exercise, whether to respond quickly or slowly to a 
student response or question" is something that you acquire by doing: "If the teacher and the class have succeeded at all, they will feel, in the moment's silence that precedes the downbeat of the last class, not the tension of the first day, but a sense of exhilaration." (Respecting the Pupil, 1981:81).

I took advantage of the methodology's strong writing component since it fitted very well with the PE genre instruction in Spanish. There is a long list of Exonians who have become distinguished writers, and many credits the Academy for fostering a love of writing and teaching to write. (Heskel, 2008:248).

Harkness is also an example to follow in contributing to a continuing assessment: during the 1997-1998 academic year, the faculty approved a student-initiated program called The Midterm Effort to Improve Classes (METIC). (Heskel, 2008:107).

At my classes in PEA, it consisted of my students having private time to discuss positives of myself as a teacher, the class as a whole, and themselves as individual students, things that could be improved, and a miscellaneous category. We then discussed together changes to enhance the teaching and learning while there was still time left in the term. 


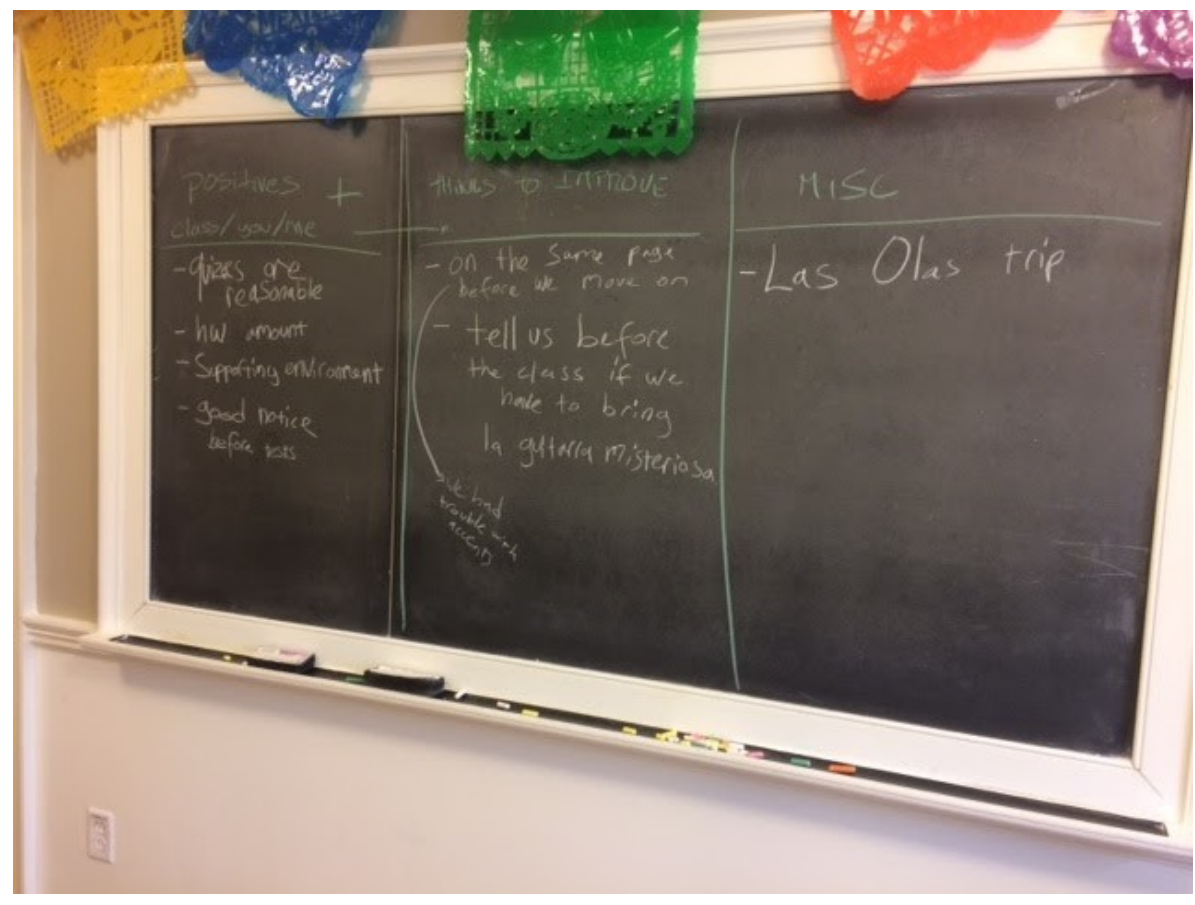

Figure 31: A METIC example from my winter term. 


\subsection{Conclusion}

This study's findings suggest a possible role for training in ethnographic techniques of unbiased observation for study-abroad participants. The objective of training language learners in ethnography is a "mix of learning to communicate appropriately and developing an analytic understanding of another group's system of meanings." (Roberts et all:11).

In such approaches, learners are trained in methods of observation, analysis, and writing, engaging them in observation of "otherness" and representing what they observe not as a set of facts but as one interpretation mediated by their cultural understandings. Learners come to understand and reflect on the nature of language learning as socialization, to appreciate the complex connection between language and culture interaction. (Agar:60) American or any language learners abroad would benefit, particularly by efforts to encourage an analytic rather than a judgmental approach to the societies where they study.

In class, engagement with specific writing tasks, authentic to the targeted genres, gave learners and myself, the teacher, the opportunity to realize how a particular context/content of writing interacts with language forms to produce meaningful communication (rather than good writing only).

SFL helped in focusing on theoretical bases for integrating language and content, on developing a curricular structure. This process led to real judgments by an actual educator in the local context. It involved real students and led to apparent differences in what, how, and what extent they learned. 
Readers of literature on applied linguistics and language learning have noted a recent surge of interest in the investigation of study-abroad contexts, no doubt reflecting the profession's growing concern for fostering language competence beyond the early stages and for developing approaches in which language and culture are no longer estranged but are appreciated in their complex interrelationship.

The study documents the experience of one group, studying one language, at a particular historical moment. In some regard, this group may be considered typical of American study-abroad participants: they were students of Spanish, a commonly taught language, majoring in various subjects while enrolled in the programs offered by a major state university.

Future research may illuminate the experiences of student groups and individuals with diverse histories of participation in language education and a variety of language foci. With the adoption of ecological approaches to second language development, this research may assist all parties in navigating language learning's complexity in study abroad toward reasoned ways to help students learn.

In addition, findings in this thesis show that study abroad in an age of globalization is, in some ways, very different from the image of the experience that we, language educators of today, had in our SLA sink/swim immersion. They offer specific implications for the design of programs aiming to assist language learners abroad, demonstrating, in particular, the relevance of training and projects involving language awareness and guidance in the interpretation of culturally grounded misunderstandings. 
This study recommends PE genre-based teaching and Harkness learning pedagogy, as its range of skills helped develop students' academic literacy. My FSU Valencia results were reassuring, but further testing was necessary for different home settings and across all levels to investigate if they could be duplicated, analyzed, and later compared. I subsequently accomplished the latter when I was able to apply instructed writing at the highest level first in the 2018 Fall semester at SAC ${ }^{47}$ and under the best class conditions later on, in the 2019 Winter and Spring terms at PEA ${ }^{48}$.

${ }^{47}$ Annex 9.3 Best Performance Composition samples from SAC students.
${ }^{48}$ Annex 9.4 Best Performance Composition samples from PEA students. 


\section{ANNEXES}

\subsection{Different Versions of the Harkness Table}

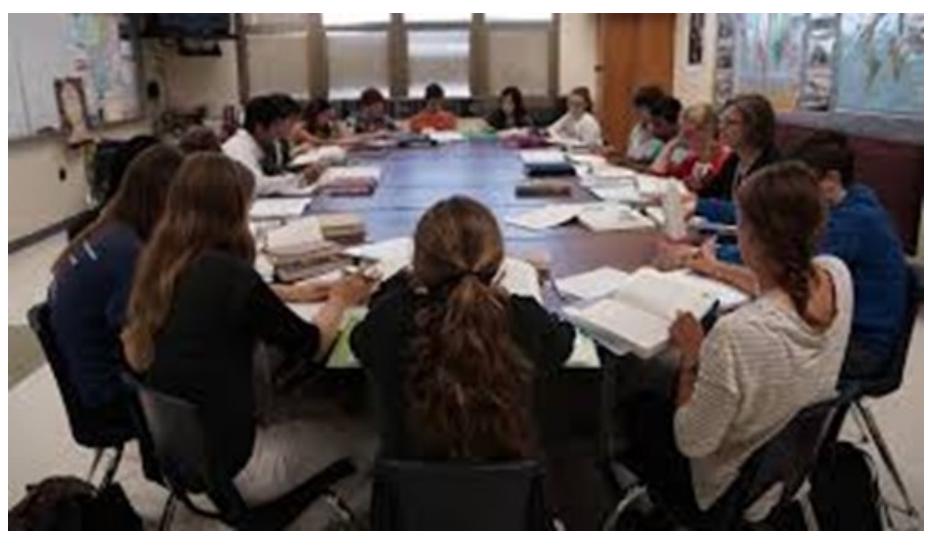

Figure 5: Wellington School, UK, Harkness sans table

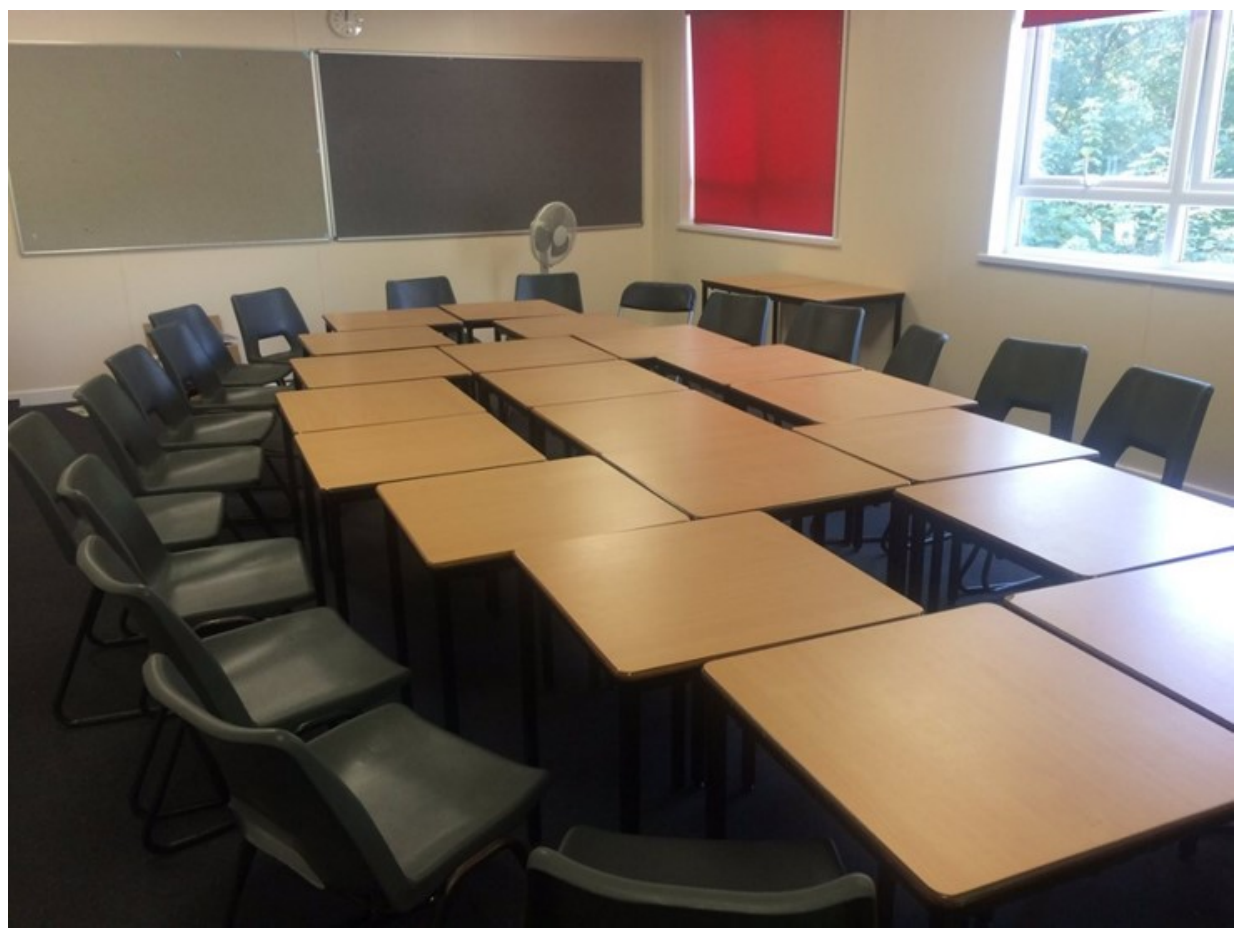

Figure 6: At Lawrenceville School new tables can be divided too. 
Harkness Table Notes

Discussion Topic:

Date:

$?=$ Asks a provocative question

$+=$ Refers specifically to the text

$\mathrm{r} \square=$ Refers to rhetoric

! = Makes an insight

$\mid \square=$ Advances the conversation

$\mathrm{C}=$ Makes a meaningful connection

$\mathrm{W} \square=$ Off-topic

$\mathrm{O} \square=$ Makes inferences based on guesswork and conjecture

$\mathrm{K} \square=$ Dominates or disrespects

Write student names around the perimeter and track their contributions to the discussion. 


\subsection{Scoring Rubric for Level II Writing Assessment}

\section{CONTENT}

\section{Up to $30 \%$ Mark (Very good)}

The story introduces much information in the background and the foreground of the personal narrative. The information is logically developed, and people, actions, experiences, events, and places are presented in plausible ways. This information pertains to both present and past events to give some dimensionality to the story.

Thus, the essay constitutes an accurate response to the exercise assigned. Some ideas are developed through subordinate and coordinate content areas that complement the story.

\section{Up to $22.5 \%$ Mark (Good)}

Whereas the main argument of the story is mostly clear, they are not developed persuasively, are loosely organized, and, at times, discontinuous. Sequencing of the content may, at times, be incomplete; at other times, engaging pieces of information are provided. In general, the content varies from easily followed to obscure at other times.

\section{Up to $15 \%$ Mark (Fair)}

Content is developed at a basic level with little creativity. At times, connections between various components are fewer, illogical, or even choppy.

In stretches of the text, the reader must fill in missing content gaps to create coherence. 


\section{Up to $7.5 \%$ Mark (Poor)}

Content is insufficient to fulfill the genre's intention and the writing task and carry the story. There is no evidence for an organization of the content logically or coherently. Ideas might be wrong, inappropriate, confused, or cliche-like.

\section{TASK ORGANIZATION}

\section{Up to $\mathbf{2 5 \%}$ Mark (Very good)}

Writing shows the main generic moves in narration: orientation, complication, evaluation, resolution, and coda.

A good facility with narration from a personal perspective is present. Texts are explicitly organized into major stages and episodes in time and space, as specified by the targeted genre and the writing task. Writers can employ diverse forms of sequencing events and express some evaluations about them (either by themselves or by other actors present), demonstrating good coherence. The narratives carry some intentions beyond locating actors and actions in time and space: to entertain, persuade, dissuade, compare and contrast, establish cause and effect, solve problems. Those intentions give cohesion to the entire text.

\section{Up to $18 \%$ Mark (Good)}

Although writing may be generally balanced, including marking topic development in sequencing and transitioning, some characteristics of the genre described are not consistent, or the narrative lacks details. Mainly the writer's intentions. Still, the writing represents a basic example of the genre and the task; it can be followed without difficulty. 


\section{Up to $12 \%$ Mark (Fair)}

The genre's characteristics are not evident, which makes the writing dispersed, even though the sentences might be accurate and interesting from the standpoint of content. The narrative is sometimes obscured in terms of continuity, the relevance of ideas, or detail.

\section{Up to $6 \%$ Mark (Poor)}

The writing is reduced to a stringing together of separate sentences and phrases that are not linked by a generic framework and do not resemble a story of consequence.

\section{LANGUAGE:}

\section{-VOCABULARY-GRAMMAR}

\section{Up to $\mathbf{V} 20 \% \mathbf{G} 25 \%$ (Very good)}

Writers succeed in creating an overall textual organization with good control of the language at the sentence level. This organization is accomplished through diverse markers of coherence and cohesion, particularly in terms of chronological sequence and through other linkages (e.g. comparison and contrast, some cause and effect markers, exemplification). Writing shows syntactic patterns for subordinate clauses with their respective word order requirements. All past tenses are used to express different facts for people, places, experiences, and events. Simultaneously, both syntactic and morphological inaccuracies still exist: in the word order of major sentence components, extended verbal structures, and gender/plural formation. Basic thematic vocabulary is used correctly. Idiomatic expressions are occasionally used to good effect. 


\section{Up to $34 \%$ mark (Good)}

Sentence patterns are less varied and show less awareness of a discourse context through markers or topic development. There is a right mix of simple and complex sentences, but the latter shows patterned errors (e.g., verb position, tense marking, clause order). Vocabulary usage shows adequate, but generally with less elaboration of the topic with few idioms.

\section{Up to $23 \%$ Mark (Fair)}

Writing is mainly focused on the sentence rather than the discourse level. Word order requirements in some sentence patterns fail. Vocabulary shows a limited range of expressiveness of the theme.

\section{Up to $12 \%$ Mark (Poor)}

Writing remains at the sentence levels, with only a few moves into discourse patterns. Errors occur in all areas of syntax and morphology with, at times, impaired comprehension, or they are so simple that they fail to communicate arguments in line with the genre and the topic. Vocabulary choices show simplistic word usage or interference from English or both and are limited in their range. 


\subsection{Writing tasks for Level II and Example Performance of One Student.}

\section{Dawson}

1-Baseline writing task: Exercise with different uses of the two forms of

Spanish verbs: Ser o Estar. Underlined word order errors or unnecessary

in Spanish.

I am from Pensacola.

I am a student from FSU.

She is a lawyer.

We are brothers.

I am tired totally.

My shirt is red.

Where are you?

I'm in the library.

Where is the bathroom?

Where are you?

\section{2-Travel Journal Trip to Andalucía: First Draft}

The first day, we went to the Cordoba.

The bus caught four hours.

We saw ourselves the Mezquita.

The Mezquita was beautiful.

Our guide of tourism Lola was the best.

The second day, we went to the Seville.

The bus caught an hour and a half.

We saw ourselves to the Spanish square first. Second we went to the Alcazar.

Then we went to the a restaurant for tapas.

The then day, we went to the Granada.

Granada were my favorite city.

The bus caught two and half hours.

We saw ourselves to the Alhambra.

La Alhambra was very magnifique.

The last day that we were Granada.

Today was a day off.

We slept in till midday.

Ryan and I went to a bathhouse.

That was the most beautiful thing that I had seen. 


\section{3-First Draft Prototypical Writing Task}

When I was young, my parents got divorced, so I used to go to school in Pensacola with my mother and I would travel to Jacksonville during the summer to visit my father. During of school year, I used to play tennis and soccer. During the summer, my sister and I used to go to a summer camp to practice tennis and to sail in the river. During of the winter holidays, my father, sister and I used to ski in Colorado. Meanwhile we were skiing in the cold, my mother would go to Hawaii to be in some hot. The last time we were at the summer camp went four years past.

\section{Spanish

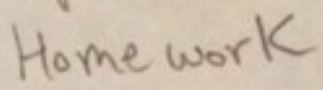

Cuando era joven, mis padres se divorciaron, $2-18-15$ asi que solia ir a la escuela en Pensacola con mi madre y viajaba a Jacksonville en el vierano para visitarami padre. Durante de año escolar, solia jugar tenis y Fúfbol. En el verano, mi hermana y yo soliamos irlcalcampamento de verano practicar tenis y navegarenel rio. Durante de las vacaciones de invierno, mi padre, hermana y yo soliamos esquiar en Colorado. Mientras, nosotros íbamos a esquiaio en el frio, mi madre iba a Hawai paratéstar esquna el cálido. El vitima vez esturimos en el ampamento de verano fue cuatro años. (pasada).
hace 


\section{4-Final PWT}

When I was young, my parents got divorced, so I used to go to school in Pensacola with my mother and I would travel to Jacksonville during the summer to visit my father. During of school year, I used play tennis and soccer. During the summer, my sister and I used to go to a summer camp to practice tennis and to sail in the river. During of winter holidays, my father, sister and I used to ski in Colorado. Meanwhile we were skiing in the cold, my mother would go to Hawaii to be in some hot. The last time we were at the summer camp was four years ago. 
REDACCION I

NOMBRE: Carl Dawson
FEBRERO 2016

content 30

jocab 20

loun: 25

-Escribe utilizando el Imperfecto + Indefinido:

- Sobre tu viaje a Andalucia o Lo que solias hacer en verano.

Cuando era joven, mis padres se divor ciaron, asi que solia ir a la escuela en Pensacola con mi madre y viajaba a Jacksonville en el verano para visitar a mi padre. Durante de año escolar. solia jugar tenis y fútbol. En el verano mi hermana y yo soliamos ir al compartamento de verano practicar tenis $y$ navegar en el rio. Durante de las vacaciones de invierno, mi padre, hermena y yo soliamos esquiar en Colorado. Mientras, nosotre ibamos a esquiar en el frio, mi madre iba a Hawai para estar esguna ell cálido. La (E) ultima ver que estuvimos en el campamento de verano fue hace cuatro años.

- 251 - 


\section{5-Letter to a friend Final Draft}

\section{Dear Paloma}

I am so glad that you are coming to Pensacola, I think you're going to like it. What I'm sorry about is that i won't be here when you arrive. I have to visit my father at the hospital. He's very sick, but doctors say he's going to be ok. Pensacola has beautiful beaches with sand and turquoise ocean that I think you will like a lot. I would like to give you various tips about the city, I will write you a list:

-from the airport, is better to take an Uber to your hotel. Taxis are too expensive and buses are too full of people.

-when you get to the beach, I recommend you to use your legs and walk. Traffic is very bad.

-I recommend you to visit Destin while you see Florida. It's an hour away but it has the best shopping.

-the same I tell you about if you want to visit FSU. Tallahassee is only two hours drive. It's better to see them during the week and not during football games.

-I think that the beach is the best place. It's advisable not to take your passport. Only bring a cloth and a lot of beers. It's better to take water too because very hot.

I recommend you to visit it Nobusei. I think is the best Japanese of restaurant in Pensacola.

-every year the king and Queen of Spain visit Pensacola. The best thing is to go to the town hall to see them.

Well I don't recall anything else.

I wish you a good trip and that your stay here would be wonderful.

Your favorite student,

Carl Dawson 
- Quevida Paloma

Me alegro muche de que vengas a Pensacda creo que teu va a gustar. Lo que siento es que no voy a esfar cuando tu llegues. Tenga que visitar a mi padre en el hospital. esta muy infermo pero los medicos dicen que va a estor bien. Pensecola tiene playas hermosas con arena blanca yoceano turquesa que pienso te gustara mucho. Me gustaria darte una serie de consejos sobre la ciudad te hag: una lista:

- desde el aerpuerte, es nejor timar un uber a su hotel. los taxis estan muy carosy los autubusos estan muy llenos

- cuando tu lleges a la playa, te vecomiendo usar sus piernas y caminar. El trafico esto muy mal

- te aconsejo visitar Destin mientras (ves ves Florida. Esta a una hora de distancia, pero tiene lo mejor para comprar. Tallahassece esta sola a dos hora de conducie. Es preferible verlas extre semana y no dusante el juego del fútbol americano

- creo que la playa es el mejor lugar. Es a consejable no llevar su pasa porte. solo traer una peño y muchas cervecas. Es mejor llevar el agua tambien porque have - te anonsejo visitarla Nobusei. Pienso que es el mejor resturante (de japones en

- 253 - 
(cont.)

todos años el rey y la
visitan Pensacola. I Lo
al ayuntamiento oparaverlos

Bueno y no se me occure nada más estancia aqui bea estopenda.

su Estudiante favorito,

Carl Dawson

- 254 - 


\section{6-Final Composition}

My intentions for next year is to get better grades. I am planning to study more and go out to party less. But before I will meet my family and we will travel to the Switzerland for four days and afterwards we go to London. The second that I arrive into the United States I will have started to study the LSAT. The LSAT is an entry exam to become a lawyer. Every day during the summer I will have studied for five hours and Tuesdays and Thursdays I will have gone to private classes. The date of the exam is in the middle of July, afterwards I will be able to go out and party for two more months. If I pass the LSAT exam I will have finished the Florida State University and I will go to lawyers' school for two more years and then I will go to work for my stepfather in his lawyers' firm. If it doesn't work, I will have used my finance degree and I study for the CLEP. If I pass the CLEP I will have found a job with a finance firm and later I will be counting numbers every day. 
COMPOSICION II

Noмвre: Caxl Daws-n
30

25
20
$V$

-Después de pensar mucho sobre tu futuro, escribe tus intenciones para el año que viene y tus decisiones también. Para finalizar ahadể las decisiones e intenciones que tienes para cuando acabés ta licenciatura en la Universidad.

Mis intenciones para el proximo año es sacar las notas mejores. Estoy planificando estudiar mas y salir de fiesta menos. Pero antes me encontraré con mi familia y viajaremos al suzia por watro dias y despues vamos a Londres. El segunolo que yo llegoea los Estados Unidos, yo habre emperado estudiar el LSAT. El LSAT esta un examen de ingresso para convertirse en un abogado. Todos dias durante de verano $y^{2}$ habe estudiado durente cinco horas y las martes y los jueves yo habre ido al las clases particulares. La Fecha del examen esta en el medio de julio, despues podre calir a la fiesta para dos meses mas. Si yo a próbo el examen de LSAT, habré terminado la universidad de Estado de Floridar Y voy a la escuela de abogado dos años mas y entonces habre ire a trabjar con mi padrastro en su bufete de abogados. Si no funciona, habre usado mi grado de fianzás
y estudiae por el CLEP. Si yo aprobo el CLEP habré encontrado un trabaj. con Mn bufete de fianzas y despues estaré contando numeros toous dias.

-256 - 


\subsection{SAC Compositions 3 and 4 Samples.}

You will write two compositions in class. The dates are listed on the calendar. The topics of the compositions will be given in class. The absence policy for compositions is the same as the absence policy for exams.

\section{Evaluation Criteria for Compositions}

$\underline{\text { Content }}$

Points

- very complete information; relevant; on target

- adequate information; some development of ideas; some ideas lack supporting detail or evidence

- limited information; ideas present but not developed; lack of supporting detail or evidence

- minimal information; information lacks substance (is superficial); inappropriate or irrelevant information; not enough information to evaluate; or word count not met 


\section{Organization}

- ideas are logically and effectively ordered; main points and details are connected with use of transitions; fluent

- an apparent order to the content is intended; somewhat choppy; loosely organized but main points do stand out although sequencing of ideas is not complete

- limited order to the content; lacks logical sequencing of ideas; ineffective ordering; very choppy; disjointed

- series of separate sentences with no transitions; disconnected ideas; no apparent order to the content; or not enough to evaluate

\section{$\underline{\text { Vocabulary }}$}

- broad; impressive; precise and effective word use and choice; extensive use of words studied

- adequate but not impressive; some erroneous word usage or choice, but meaning is not confused or obscured; some use of words studied 
- erroneous word use or choice leads to confused or obscured meaning; some literal translations and invented words; limited use of words studied

- inadequate; repetitive; incorrect use or non-use of words 13-0 studied; literal translations; abundance of invented words; or not enough to evaluate

Language

- minor or no errors in the grammar presented in lesson; very few errors in subject/verb or adjective/noun agreement; work was well edited for language

- occasional in the grammar presented in lesson; occasional errors in subject/verb or adjective/noun agreement; erroneous use of language does not impede comprehensibility; some editing for language evident but not complete

- $\quad$ several in the grammar presented in lesson; some errors in subject/verb agreement; some errors in adjective/noun agreement; erroneous use of language often impedes comprehensibility; work was poorly edited for language 
- constant errors in use and form of the grammar presented in lesson; frequent errors in subject/verb agreement; nonSpanish sentence structure; erroneous use of language makes the work mostly incomprehensible; no evidence of having edited the work for language; or not enough to evaluate

Total points 
Instrucciones para la composición \#3: Hipótesis y el subjuntivo (Portales)

\section{Tema: ¿Qué hubiera pasado?}

\section{OPCION A}

Imagina lo que hubiera pasado si un familiar mayor hubiera tomado diferentes decisiones

-Si hubiera elegido otra profesion, otra ciudad donde vivir, otra region o pais por ejemplo.

-Si hubiera resuelto no estudiar e irse de viaje por el mundo

-Si hubiera decidido, en el ultimo momento, no casarse, tener hijos.

-Si hubiera dicho algo (a alguien) pero no pudo en ese momento. Si hubiera educado a sus hijos de otra manera.

Todos hemos oido a personas mayores sobre sus arrepentimientos (regrets) a lo largo de sus vidas.

- Escribe una carta dirigida a sus nietos, familiares o amigos donde esta persona mayor explica lo que hubiera hecho mejor o de otra manera.

- Escribe las recomendaciones (usando el presente de subjuntivo \& WEIRDO) y consejos que aprendio de su experiencia/s. Escribe sobre posibles problemas que pueden ocurrir en tu vida y sugerencias de cómo resolverlos.

- Escribe sobre lugares/ atracciones importantes o interesantes que debes visitar y por qué son importantes o interesantes.

* ¡Sé lo/la más creativo/a posible!

\section{OPCION B}

Imagina si algun hecho en el pasado (historico o no) no hubiera ocurrido. Por ejemplo:

-La electricidad no se ha inventado todavia.

-Los Estados Unidos intervienen en La Guerra Civil Española en 1936 y con su ayuda vencen al fascismo. En ese caso como la parte ganadora seria republicana (not with the King in Spain) no habria realeza ahora

-Se acaba el petroleo y la electricidad no se ha inventado todavia

-Otro topico que te interese, jImaginacion al Poder! 


\section{Tu composición debe incluir:}

1) Vocabulario de los capitulos de Portales. ¡Sé creativo/a!

2) Usos de gramática apropiada: Si clauses, El subjuntivo, El indicativo y / o El futuro.

3) Palabras de transición

\begin{tabular}{|c|c|c|}
\hline Siempre=always & Nunca $=$ never & Generalmente, frecuentemente, normalmente \\
\hline A veces $=$ sometimes & A menudo $=$ often & También $=$ too, also $\quad$ Tampoco $=$ neither \\
\hline Sin embargo $=$ however & \multicolumn{2}{|c|}{ Por eso $=$ for that, because of that Entonces=therefore } \\
\hline \multicolumn{3}{|c|}{ Afortunadamente=Fortunately Desafortunadamente=Unfortunately } \\
\hline \multicolumn{3}{|c|}{ Por un lado $=$ On the one hand } \\
\hline \multicolumn{3}{|c|}{ Sin embargo $=$ Nevertheless } \\
\hline Por otro lado=On the oth & er hand & ontrario $=$ On the contrary \\
\hline
\end{tabular}

4) La composición debe contener 250-300 palabras (25-30 frases)

5) La composición debe tener 3 partes: Introducción, Cuerpo (body), Conclusión

REMEMBER: The use of translation software or programs or the aid of a Native Speaker or tutor is NOT ALLOWED and violates the academic integrity policy as stated on the syllabus.

Fecha: lunes 19 de noviembre in class. LA NOTA (grade): Tu composición va a ser evaluada por 1. ) el contenido, 2. ) el seguimiento (following) de las instrucciones, 3.) el uso correcto de la gramática, y 4.) el vocabulario/creatividad

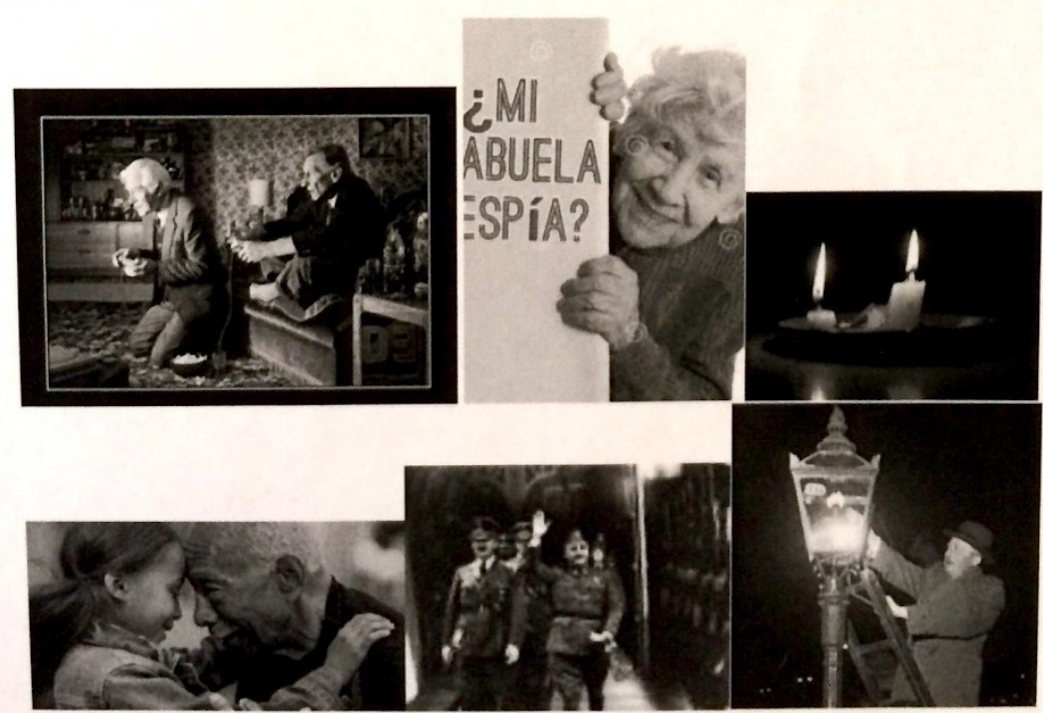




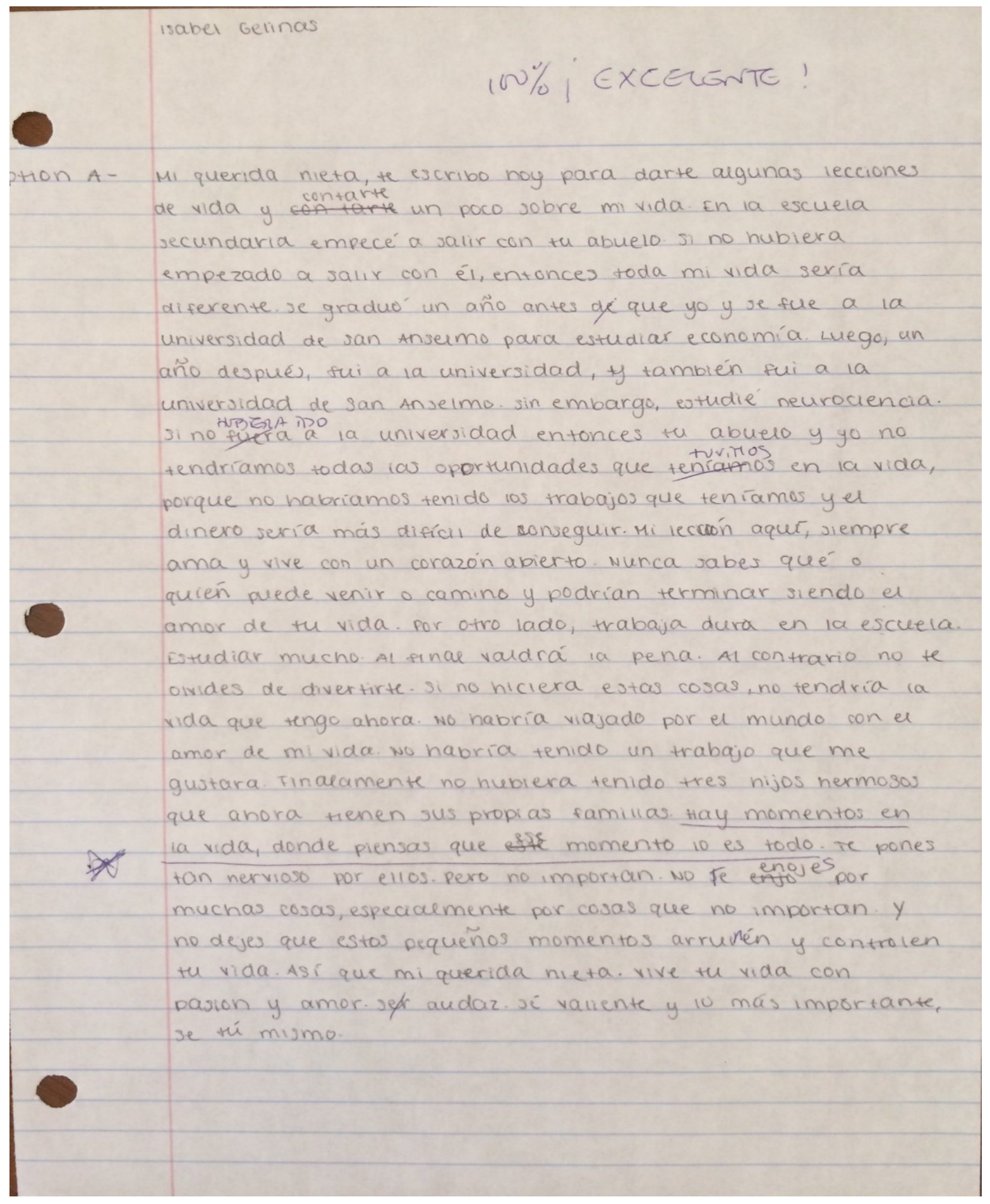




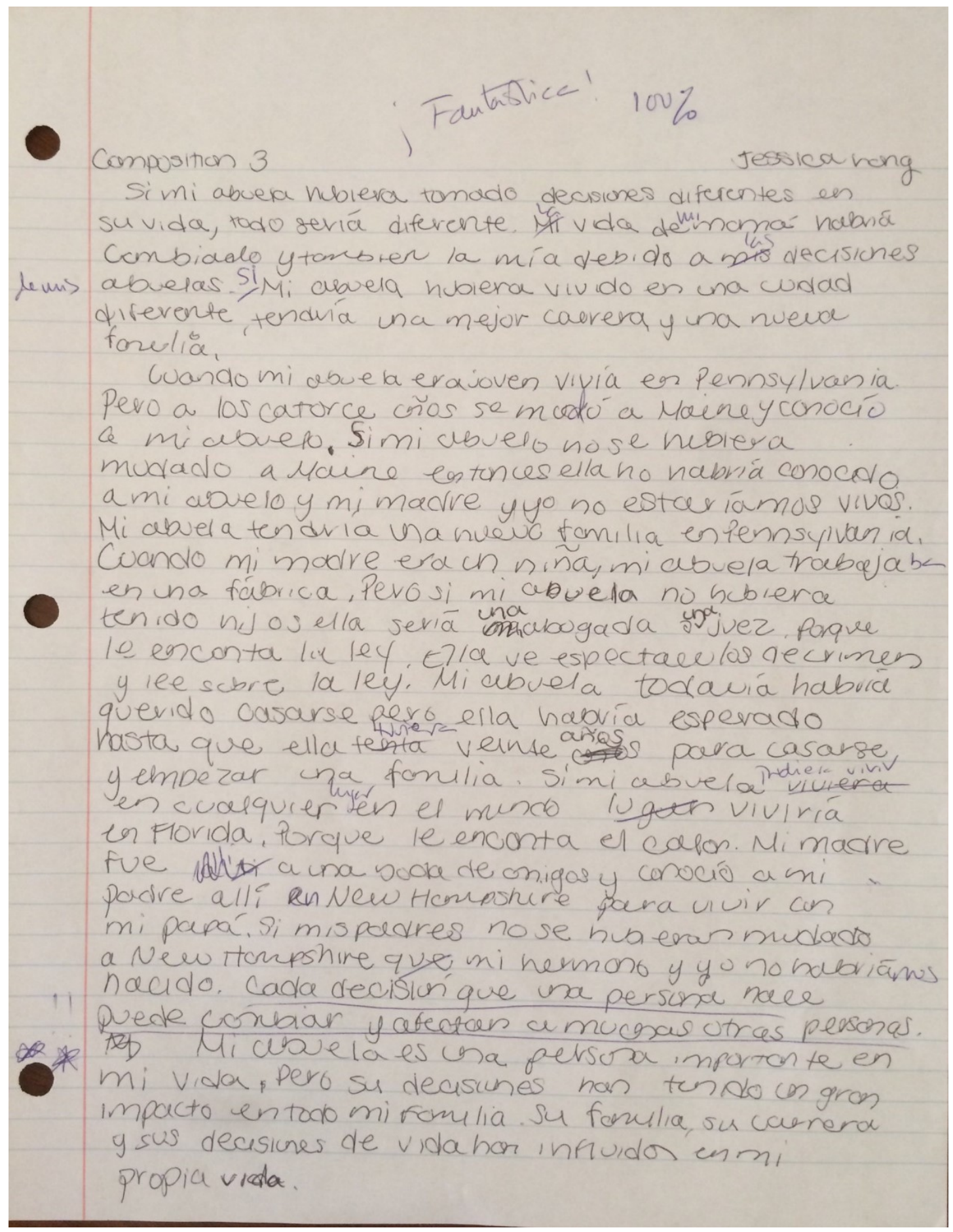




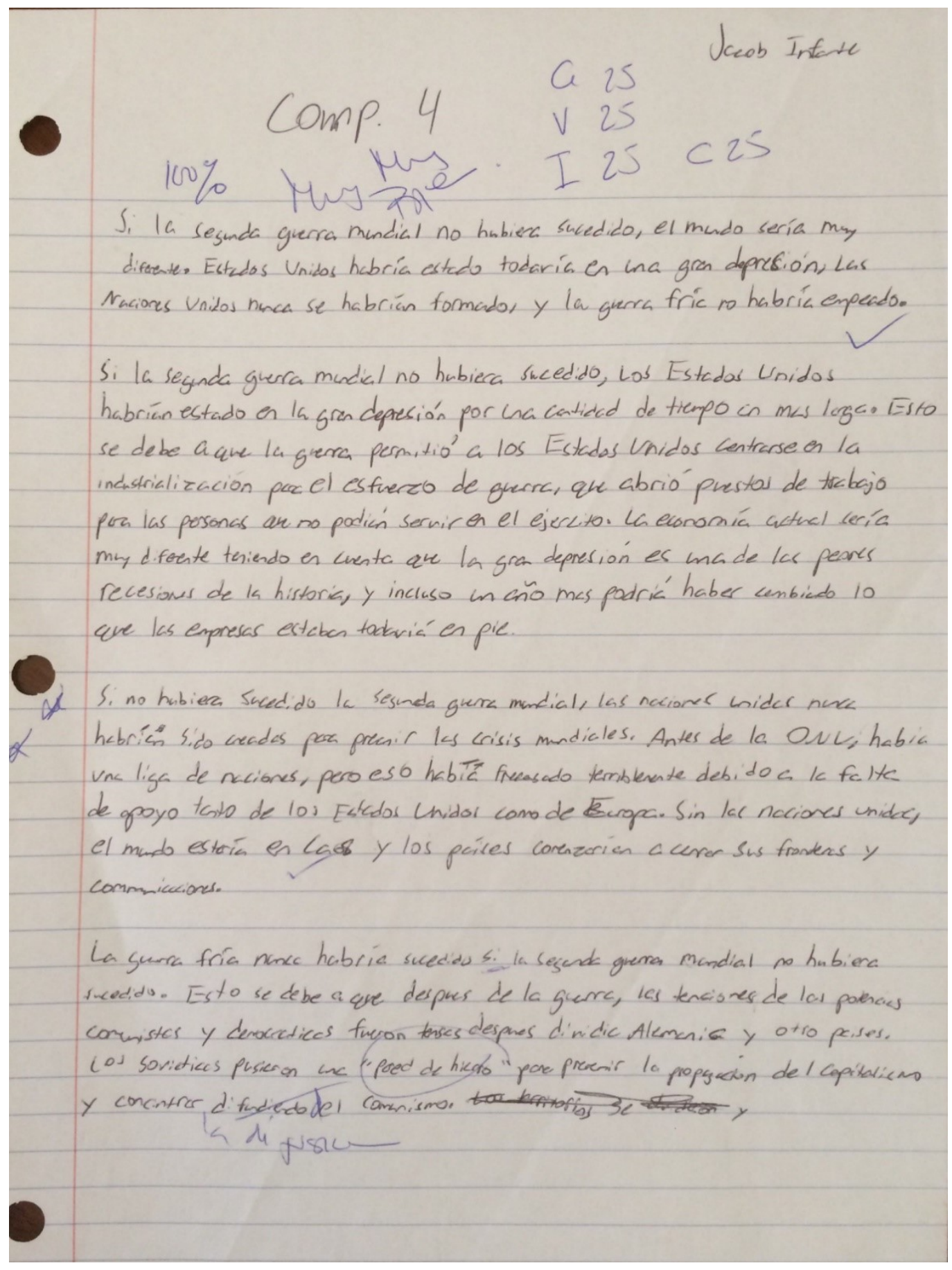


Maryhate Albert

$$
\text { composition \#3 } \quad 100 \%
$$

$11 / 19 / 18$

Si Cristóbal, Colón nunca hubiera llegado a 14 finérica del Norte, muschas cosas serian diferentes aqui hoy. Cambió el modo de vida en lste continente, tanto negativa como positivamenteEu impacto de Colón en los nativos americanos fue catastrófico, causando que miles murieran. Los usó para la mano de obra barata é hizo sus vidas miserables. Los nativos no eran immunes a los mismos gérmeres que los exploradores, asi que la enfermedad se propagó rápidmente. Por otro lado. Colón trajo beneficios al continente- Instituyó el intercambio actroperabta de columbus, un complejo. sistema de comercio que trajo nuevo productos a América del Norte. Los Cultivos y alimentos que nunca antes habi an estado eh América se podian encontrar en el caribe. Esto empeoró la vida de los nattivos, ya que se vieron obligados a + rabajar duro para mantener yivos el comercio y produrtividad. Si Colón no nubiera hecho su viaje en 1492 , la población de América del Norte oodria haber sido muy diferente. Menos europeos y colonizadores habrian establecido hogares aqué. Los nativos americanos serian mas prominentes. ya que su población no habria sido 
eliminada. Las tierras natives no habrian sido tomadas injustamente. Colón trajo mevos oportunidades a America del Norte pero 10 hizo a expensas de los nativos americanos.

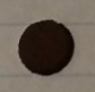




\subsection{PEA Composition Samples and Subordinate Clauses per T-Unit}

\section{S1 Diwura}

Mi primer invierno en Estados Unidos estuvo muy memorable. Me había mudado a los Estados Unidos hace un par de meses y no me prepare para el clima frio. Mi madre no supe comprar ropa de invierno. No tuve un abrigo, unos suéter, unos guantes, o unas botas. Mi madre y yo fuimos a la tienda de Burlington y buscamos un abrigo y otras ropas de invierno. Después de comprar las ropas caminé afuera y tuve una reacción alérgica. Fuimos al hospital y vimos a un médico, después de un examen ella de que yo alérgico al clima frio. No salí de mi casa desde noviembre hasta marzo. Estaba aburrido todo el tiempo, pero no muy estuvo mal el invierno porque mi familia estaba conmigo. Ahora se siempre como estar preparada para el clima. Sb: $21 \mathrm{w}$

\section{S2 Keona}

Hace unos pocos años, mi abuela nos visitó en Hawaii. Planeamos organizar todo para estar seguros, pero algo paso de todos modos.

Yo estaba en mi cuarto, y oí un golpe de la cocina. No pensé que fuera importante, pero fue. Mi madre dijo a mi hermana y a mí que viniéramos a la cocina. Cuando empezamos a caminar, vimos que nuestra abuela estaba en el piso. Recuerdo que mi hermana y yo estuvimos jugando un juego, por eso no le prestamos atención. Las tres buscamos heridas, y vimos una en la cabeza. La sangre se había puesto en la camisa que llevaba puesta. Tuvimos que llamar a la sala de emergencias, y mi abuela termino con puntos de sutura. Mi mama escribió su número de celular para emergencias, yo leí, y ella se fue para la sala de emergencias con mi abuela. Creíamos que nuestra abuela estaría bien, y esperamos su vuelta.

Cuando los médicos cerraron las puertas de la ambulancia, sentí ganas de llorar. Por suerte, mi abuela sobrevivió y todavía está bien hasta hoy. Sb: 39

\section{S3 Bradley}

Hace tres años mi familia y yo fuimos al país de Aruba. Durante los últimos días antes de que volviéramos a Nuevo Hampshire, buscábamos cosas que hacer. Mi hermano dijo: “! ¡Vamos a la Playa!". Por un lado, la playa estaba bien, pero, por otro lado, ya íbamos a la playa todos los días de vacaciones, y quisimos hacer otra cosa. Mi papa pensó, antes de decir:

"¿Quieres hacer un recorrido por la isla?" Estuvimos de acuerdo, y pronto llegamos a la agencia de excursiones, y entramos en una jeep. Fuimos alrededor de la isla, y llegamos a un acantilado alto sobre el océano. El agente de excursiones me dijo:

¿¿Quieres saltar?" Estuve asustado, pero estuve de acuerdo, y salte. 
Tuve miedo del salto, pero también fue uno de los mejores momentos de mi vida. No tengo nada de miedo a las alturas ahora. $\mathrm{Sb}: 11$

\section{S4 Justin}

Hace unos años, cuando estaba en la escuela, había una asesino que había escapado cerca. Yo recuerdo que escuche la alerta en el teléfono de mi profesor. Yo estaba en clase y por eso, no tenía mi teléfono. Yo empecé a bloquear las puertas y cerrar las ventanas. yo regresé a mi escritorio y vi a los niños asustados y llorando. Pensé que esto significaba que yo podría ser recogido temprano.

Mientras el asesino estaba perdido en nuestra escuela, la clase se había detenido por completo. afortunadamente para mí, yo había recordado traer un buen libro. Yo saque las papas fritas que compro mi madre, pero alguien me vio. Él dijo que el me pagaba si quería algo. Yo le vendí un chip y luego, los otros chicos compraron un poco. Yo pensé que, aunque daba miedo. el día no estaba mal. cuando yo llegue a casa, y Conte a mis padres las experiencias de mi día y ellos se rieron. $\mathrm{Sb}: 35$

\section{S5 Oliver}

El verano pasado, toque la guitarra en una actuación en la universidad de la música de Berklee. antes de la actuación, organice una banda. La banda tuvo dos cantantes, dos guitarristas, un bajista y un batería. sin embargo, estuve nervioso y emocionado por la actuación. Cuando el día de la actuación llego, yo vi a mis padres en el público. Recuerdo pensar que necesitaba darles una buena impresión. Durante una hora yo escuche a las otras bandas. Después de que las otras bandas terminaron, yo fui a escena. Busqué a mis padres en el público y los encontré. Mi padre llevo una camisa roja y blue jeans y mi madre llevo un vestido blanco. Empecé a tocar la guitarra. los cantantes oyeron la música y cantaron. también el bajista y el batería empezaron a tocar. Tocamos muy bien y el público aplaudió. Después de la actuación mis padres me compraron un helado. Fue un gran día. Esa noche, leí revistas de guitarra y escribí en mi diario sobre el día. espero recordar este día para siempre. Este verano quiero tocar la guitarra en Berklee para tener más recuerdos y divertirme. Sb: 27

\section{S6 Spencer}

La semana pasada mis amigos y yo vimos el Super Bowl en la televisión. Mi amigo Aidan organizo la fiesta. Antes de llegar a la casa de mi amigo, compre una bolsa de papas fritas. Yo llegue a su casa esa noche. Cerré la puerta de su casa y dije ¡Hola todos! Quise una victoria de los patriotas porque el año pasado perdieron contra los Águilas. ! ¡Los patriotas son mi equipo favorito! A las seis y media el partido empezó. También vimos los anuncios. Ford quiso vender carros. El partido fue ajustado, pero todavía creí en los patriotas. ! ¡A las nueve y media oí que 
los patriotas ganaron! Yo dije tengo que ir me. Muchas gracias, Aidan. Después del partido volví a mi casa. Yo tuve un día divertido. Sb: 17

\section{S7 Taylor}

El año pasado, mi familia fue a las Floridas Keys. Mi abuela organizo el viaje y compro los boletos para el crucero. Cuando llegamos, recordé durante el crucero que mi hermana y yo escuchábamos las olas todo el día. Jugamos en la arcada y jugamos baloncesto con mi hermano. En la playa, mis primos y yo tomamos el sol y jugamos al voleibol. Vi un pez en el agua. Fue en julio y la temperatura fue muy caliente. Nadé con delfines y comí diferentes alimentos en Cozumel. Al final del viaje, estamos cansados. Cerré la puerta del hotel y escribí una nota para el limpiador. Sb: 13

\section{S8 Chichi}

Ayer, dormí hasta las once de la mañana porque me dormí tarde la noche anterior. Entonces, yo llame a mi amiga y comimos el desayuno. Entonces, fuimos a la sala de estudiantes de día e hicimos la tarea. ¡Yo tuve hambre otra vez! Yo compré ramen y comí con un tenedor pequeño que conseguí de mi amiga en Hoyt. Y tomé un descanso y vi videos de Youtube. Yo también leí algunos artículos de noticias. Yo recordé que mi dormitorio estaba sucio y yo cerré mi ordenador portátil. I ande a mi dormitorio y lo organicé. Cuando termine pase un rato con mis amigos. Sb: 7

\section{S9 Katie}

Yo recuerdo una vez que fui a la ciudad de Paris. Mi familia y yo fuimos a celebrar la Navidad. Nosotros compramos los billetes eran baratos. Salimos de Exeter una semana antes de Navidad porque quisimos tener tiempo para ir de compras. También, cuando mi familia llego a Paris, era muy tarde así que dormimos mucho. Después, nosotros viajamos alrededor de la ciudad de Paris. En la noche de Navidad vimos una obra de teatro. Después de ver una obra tuvimos cena juntos. También fuimos para ir de compras. Yo gaste el dinero en efectivo en los regalos para mi familia. Volvimos a Exeter dos días después de la Navidad. ¡El viaje fue uy divertido! Sb: 27

\section{S10 Harry}

En el pasado mi familia y yo fuimos a Puerto Peñasco, Mexico. Las vacaciones fueron muy divertidas.

Caminé por la playa y cogí las conchas elegantes. Una vez fuimos a comprar gafas de sol. En Mexico hace mucho calor. Lleve los pantalones cortos, las sandalias y la camiseta porque hacía mucho calor. En el mercado al aire libre, un vendedor vendía mangos. jestuvieron deliciosos! También, una tienda vendía insectos mexicanos de talavera. Compre un saltamontes hermosos. 
Después fuimos a un almacén. ¡No leímos los precios! Sin embargo, el dependiente hablaba poco inglés. Esa noche teníamos una fogata y vi las estrellas. El viaje fue un poco difícil porque la persona no hablamos mucho español. Todavía me gusta mucho. Sb: 11

\section{S11 Yasemin}

El año pasado, mi familia, mis amigos y yo fuimos a Grecia en barco. Hizo mucho calor y nosotros estuvimos aburridos. Así que, yo lleve mi traje de baño y nade. Mi amiga leyó un libro y mis padres jugaron a las cartas. De repente mi madre dijo: "Yasemin, vuelve al barco!".

Mis padres querían ir a la isla. Mi padre encendió el motor, pero el barco no movió. "Yo vi la isla, nosotros necesitamos ir allí.", mi amiga dijo. Mi padre dijo "Espera..." El pensó sobre algo. El busco el problema. Afortunadamente, la gente de la isla vinieron a el barco para ayudar. Después, nosotros compramos un helado en la isla y mi padre vio algo. ¡El barco no tenía la hélice! La hélice cayo en el mar. Yo recordé esta situación siempre que estoy en un barco. Sb: 6

\section{S12 Antonio}

Yo recuerdo cuando yo estaba mirando a dos jugadores profesional de baloncesto. Todo mi barrio estaba ahí. Todas las personas estaban buscando asientos para sentarse y ver el partido. Los primeros minutos del partido fueron muy lentos porque el partido estaba empezando. Pero cuando el partido estaba cerca del final toda la gente estaba gritando por Kyrie Irving o Kevin Durant. Había mucho ruido no se podía oír nada. La gente tenía comida y refrescos que ya habían comprado más temprano. Yo pienso que Kevin Durant tenía casi 50 puntos. el último minuto del partido, yo leí el marcador, y la puntuación era de 125-123 con el equipo de Kevin Durant al frente. en ese minuto Kyrie Irving tenía la pelota y lo tiro por la canasta. Cuando Kyrie Irving hace el tiro y todo la gente grito con alegría porque ese tiro cerro la victoria para su equipo. $\mathrm{Sb}: 23$

Total n. words Clauses: 233

MLC=Mean length of clauses: 5.83

$\mathrm{CTU}=$ clauses per T-Unit: 3.33 


\subsection{Original size figures}

\section{The 3 metafunctions of language}

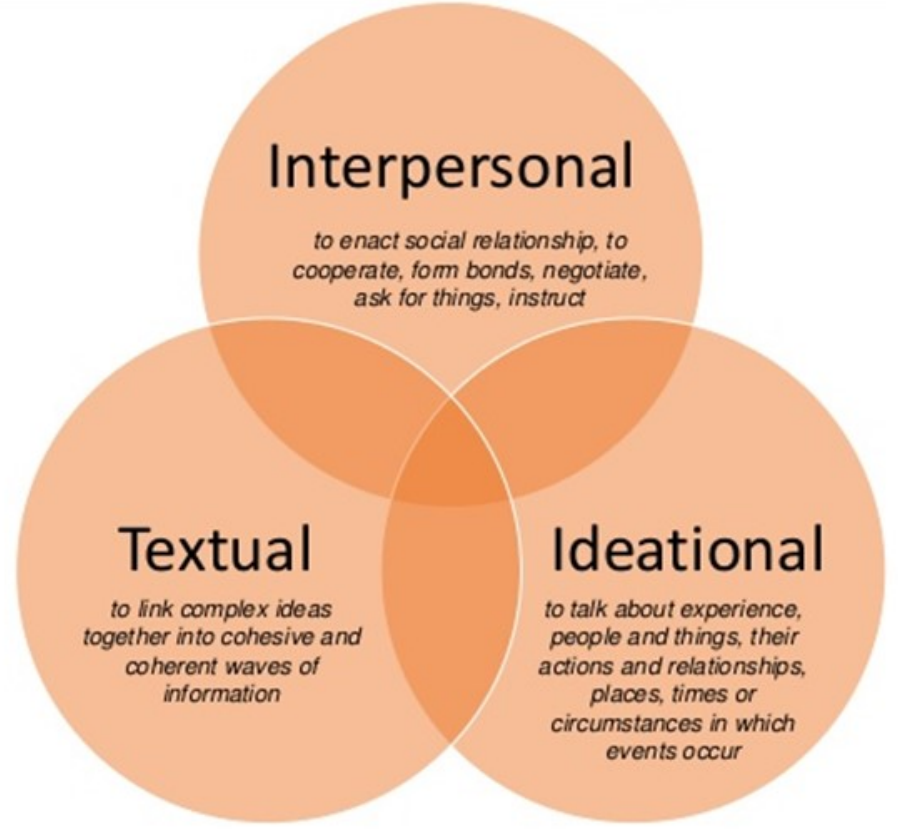

By looking at the different types of clauses we use and how we use them, we can see how language helps us to do these things. 


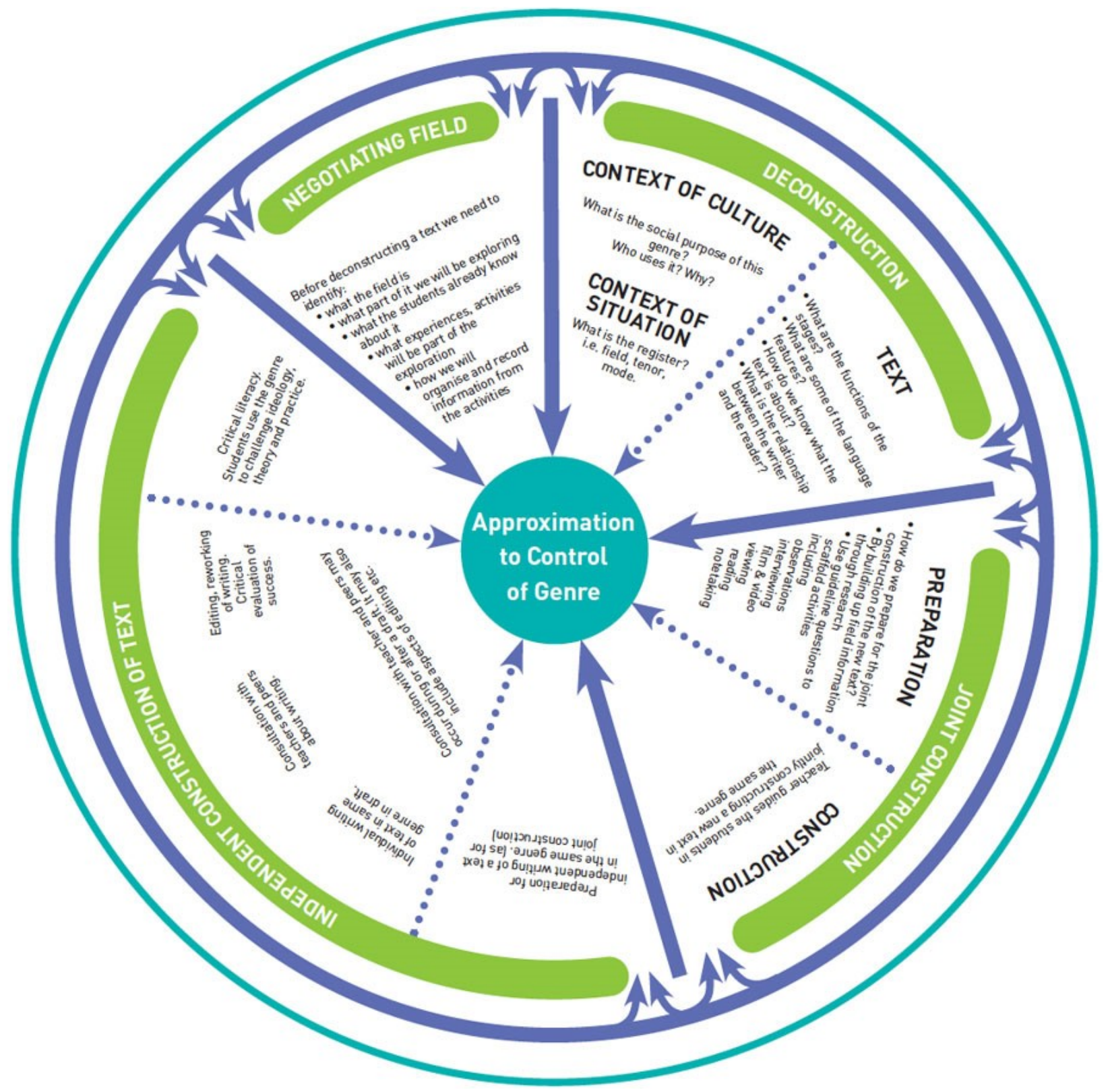




\section{BIBLIOGRAPHY}

Agar, M. (1994). Language shock: Understanding the culture of conversation.

New York: William Morrow and Company.

Allen \& Paesani (2010). Feasibility of a Pedagogy of Multiliteracies. UC Berkeley

L2 Journal Vol. 2 (1).

Allwright, D. (2005). From Teaching Points to Learning Opportunities

and beyond. TESOL Quarterly, 39, 9-31.

Alvarez, J. (1998). Something to declare: Essays. Algonquin Books.

American Council on the Teaching of Foreign Languages. (1986). ACTFL

Proficiency Guidelines. Hastings-on-Hudson, NY.

American Council on the Teaching of Foreign Languages. (2001). ACTFL

Preliminary Proficiency Guidelines Writing.

Archangeli, M. (1999). Study Abroad and Experiential Learning in

Salzburg, Austria. Foreign Language Annals, 32, 115- 124.

Arenas, R. (2010). Before night falls. United Kingdom: Profile Books.

Askehave, I., Swales, J., (2001). Genre Identification and

Communicative Purpose: A Problem and a Possible Solution.

Applied Linguistics 22(2), 195-212.

Atkinson, R. (1998). The life story interview. Thousand Oaks, CA: Sage. 
Bailey, K. (1980). An Introspective Analysis of an Individual Language Learning Experience in R. Scarcella and S. Krashen (eds): Research in Second Language Acquisition: Selected Papers of the Los Angeles Second Language Acquisition Research Forum. Rowley, MA: Newbury House, pp. 58-65.

Bailey, K. (1983). Competitiveness and Anxiety in Adult Second Language Learning: Looking at and through Diary Studies in H. Seliger and M. Long (eds): Classroom Oriented Research in Second Language Acquisition. Rowley, MA: Newbury House, pp. 67-102.

Baldwin, J. (1984). Notes of a native son. In Natalie Goldberg (2009), Old Friend From Far Away. Simon and Schuster.

Ballantine, P. (2011). Things I like about America: Personal narratives. Hawthorne Books.

Ballantine, P. (2011). 501 minutes to Christ: Personal essays. Hawthorne books.

Bakhtin, M. (1981). The dialogic imagination. Austin, TX: University of Texas Press.

Barthes, R. (1966). 'Introduction a L'analyse Structurale des Recits'. Communications 8: 1-27.

Batstone, R. (2002). Making Sense of New Language: A Discourse Perspective. Language Awareness 11/1, 14-28.

Bazerman, C. (1988). Shaping written knowledge. Madison: University of Wisconsin Press.

Bazerman, C. (1994). Constructing experience. Carbondale, II: Southern Illinois University Press. 
Bazerman, C. (2004b). Speech acts, genres, and activity systems: How texts organize activity and people. In C. Bazerman \& P. Prior (Eds.), What writing does and how it does it: An introduction to analyzing texts and textual practices (pp. 309-339). Mahwah, NJ: Erlbaum.

Beaufort, A. (2000). Learning the Trade: A Social Apprenticeship Model for Gaining Writing Expertise. Written Communication 17:185-223.

Belz, J. (2002). Second Language Play as A Representation Of The Multicompetent Self in Foreign Language Study. Journal of Language, Identity, and Education 1/1: 13-39.

Belz, J.A. \& S. Thorne (Eds.). (2006). Internet-mediated intercultural foreign language education. Boston: Heinle.

Bereiter, C., Scardamalia, M. (1987) The Psychology of written composition. UK: Routledge.

Berman, R. A. (2002). Foreign Languages and Foreign Cultures. ADFL Bulletin, 33(2), 5- 7.

Bernardini, S., (2004). Corpora in the classroom. An overview and some reflections on future developments. In: Sinclair, J.M. (Ed.), How to Use Corpora in Language Teaching. John Benjamins: Amsterdam/Philadelphia, pp. 15-36.

Bernhardt, E. B. (1991). Developments in second language literacy research: Retrospective and prospective views for the classroom. In B. F. Freed (Ed.), Foreign language acquisition research and the classroom (pp. 221- 251). Lexington, MA: D. C. Heath. 
Bernhardt, E. B. (1998). Sociohistorical perspectives on language teaching in the modern United States. In H. Byrnes (Ed.), Learning foreign and second languages: Perspectives in research and scholarship (pp. 39-57). New York: MLA.

Besemeres, M. (2002). Translating one's self. Oxford: Peter Lang.

Besemeres, M. (2004). Different languages, different emotions:

Perspectives from autobiographical literature. Journal of Multilingual and Multicultural Development 25/2-3: 140-58

Bhatia, V.K., (2002). Applied genre analysis: analytical advances and pedagogical procedures. In: Johns, A.M. (Ed.), Genre in the classroom: multiple perspectives. Lawrence Erlbaum, Mahwa, New Jersey, pp. 279-283.

Block, D. (2007a). Second language identities. London: Continuum.

Block, D. (2007b). The Rise of identity in SLA research: Post Firth and Wagner (1997). Modern Language Journal, 91, 863- 876.

Bolitho, R., Carter, R., Hughes, R., Ivanic, R., Masuhara, H., \& Tomlinson, B. (2003). Ten questions about language awareness. ELT Journal, 57, 251-259.

Bourdieu, Pierre (1995) Language and symbolic power. Cambridge, MA: Harvard University Press.

Bowers, C. G. (2018). My mission to Spain: Watching the rehearsal for World War II. (n.p.): Muriwai Books. 
Brindley, G. (1994). Task-centered language assessment in language learning: the promise and the challenge. In N. Bird, P. Falvey, A. Tsui, D. Allison, \& A. McNeill (Eds.), Language and learning: Papers presented at the Annual International Language in Education Conference, Hong Kong, 1993 (pp. 73- 94). Hong Kong: Hong Kong Education Department.

Brooks-Lewis A.K. (2009). Adult learners' perceptions of the incorporation of their L1 in foreign language teaching and learning. Applied Linguistics, 30/2: 216-235 Oxford University Press.

Brown, J D, T Hilgers, and J Marsella. (1991). Essay prompts and topics, minimizing the effects of mean differences Written Communication $8 / 4,533-56$

Browing, D. (2011). Slow love: How I lost my job, put on my pajamas, and found happiness. Penguin Group (USA) LLC

Bruner, J. (1987). Life as narrative, Social Research 54/1: 11-32.

Burroughs, A. Dry: A memoir. (2013). Picador.

Butzkamm, W. (2003). We only learn language once.

The role of the mother tongue in FL classrooms: death of a dogma, Language Learning Journal Winter 2003/28, 29-39.

Byrnes, H. (1998). Constructing curricula in collegiate foreign language departments. In H. Byrnes (Ed.), Learning foreign and second languages: Perspectives in research and scholarship (pp. 262- 295). New York: MLA.

Byrnes, H. (2002b). The role of task and task-based assessment in a content-oriented collegiate Fl curriculum. Language Testing, 19, 419-437. 
Byrnes, H., Crane, C., Maxim, H. H., \& Sprang, K. A. (2006). Taking text to task: issues and choices in curriculum construction. ITL: International Journal of Applied Linguistics, 152, 85-110.

Byrnes, H. (2006a). A semiotic perspective on culture and foreign language teaching: implications for collegiate materials development. In V. Galloway \& B. Cothran (Eds.), Language and culture out of bounds: Discipline-blurred perspectives on the foreign language classroom (pp. 37-66). Boston: Heinle Thomson.

Byrnes, H. (Ed.). (2006b). Perspectives: interrogating communicative competence as a framework for collegiate foreign language study. Modern Language Journal, 90, 244- 266.

Byrnes, H. (2009a). Emergent L2 German writing ability in a curricular context: a longitudinal study of grammatical metaphor. Linguistics and Education, 20, 50- 66 .

Caldwell, G. (2007). A Strong west wind: A memoir. NY: Random House LLC.

Calvin, L. (1999). Culture within and around: the language learning stories of adult ESL learners in a cross-cultural immersion setting. Unpublished doctoral dissertation, School of Education: Indiana University.

Canagarajah, S. (2004). Multilingual writers and the struggle for voice in academic discourse. In A. Pavlenko \& A. Blackledge (Eds.), Negotiation of identities in multilingual contexts (pp. 266-289). Clevedon, UK: Multilingual Matters. 
Canale, M., \& Swain, M. (1980). Theoretical bases of communicative approaches to second language teaching and testing. Applied Linguistics, 1, 1- 47.

Candy, P. C. (1991). Self-direction for lifelong learning. San Francisco, CA: Jossey-Bass.

Caplan, L. (2016,9,6th). Chicago hope, Can the collaboration between a progressive boarding school and a big-city charter academy transform American Public High School Education? The American Scholar. Retrieved from URL.

Carroll, J. (1967). Foreign language proficiency levels attained by language majors near graduation from college. Foreign Language Annals, 1, 131- 151.

Casanave, C. (2002). Writing games: Multicultural case studies of academic literacy in higher education. Mahwah, $\mathrm{NJ}$ : Lawrence Erlbaum.

Chafe, W. (ed.) (1980). The Pear stories: Cognitive, cultural, and linguistic aspects of narrative production. Norwood, NJ: Ablex.

Chafe, W. (1998). Things we can learn from repeated tellings of the same experience, Narrative Inquiry 8/2: 269-85.

Clandinin, D. and F. Connelly. (2000). Narrative inquiry: Experience and story in qualitative research. San Francisco, CA: Jossey-Bass.

Coffin, C. (2006). Historical discourse: The language of time, cause and evaluation. London: Continuum.

Connor, U. (1990). Linguistic/Rhetorical measures for international persuasive student writing. Research in the Teaching of English 24/1: 67-85. 
Cook, V. (2001). Using the first language in the classroom, UTP Journal 57/3, $1-14$.

Coleman, J. (1997). Residence abroad within language study. Language Teaching, 30, 1-20.

Coleman, A. (1929). The teaching of modern foreign languages in the United States. New York: Macmillan.

Coleman, J. (2005). Residence Abroad. In J. A. Coleman \& J. Klapper (Eds.), Effective learning and teaching in modern languages (pp. 126-132). London: Routledge.

Collentine, J. (2004). The effects of learning contexts on morphosyntactic and lexical development. Studies in Second Language Acquisition, 26: 227- 248.

Council of Europe. (2001). Common European Framework of Reference for Languages. Strasbourg: Cambridge University Press.

Cortazzi, M. (1993). Narrative analysis. Brighton: Falmer Press.

Crapanzano, V. (1984). Life-histories, American Anthropologist 86: 953-60.

Crane, C. (2008). evaluative choice in advanced I2 writing of German: a genre perspective (doctoral dissertation). Available from Dissertation Abstract International database (UMI No. 3376918).

Crawshaw, R., B. Callen, and K. Tusting. (2001). Attesting the self: Narration and identity change during periods of residence abroad, Language and Intercultural Communication 1/2: 101-19. 
Crismore, A, R Markannen, and M S. Steffenson, (1993). Metadiscourse in persuasive writing a study of texts written by American and Finnish university students Written Communication: 10/1: 39-71.

Crosbie, M. L. (1923) The Phillips Exeter Academy: A history. Boston: Plimpton Press.

Cumming, A., \& Riazi, A. (2000). Building models of adult second-language writing instruction. Learning and Instruction, 10: 55- 71.

Christie, F. (1989). Language development in education. In R. Hasan \& J. R. Martin (Eds.), Language development: Learning language, learning culture (pp. 152- 198). Norwood, NJ: Ablex.

Christie, F., \& Derewianka, B. (2008). School discourse: Writing across the years of schooling. London: Continuum.

Davidson, N. C. (2006). 36 Views of Mount Fuji: On finding myself in Japan. NC: Duke University press Books.

Davies, B. and R. Harre. (1990). Positioning: The discursive production of selves, Journal for the Theory of Social Behavior 20: 43-63.

Deller, S. and M. Rinvolucri. (2002). Using the mother tongue. London: First Person Publishing.

De Castro Castro, C., (2013). De escribir y describir, Porta Linguarum 19: pp. 23-4.

DeKeyser, R. (1991). foreign language development during a semester abroad. In B. F. Freed (Ed.), Foreign language acquisition research and the classroom (pp. 104-199). Lexington, MA: D.C. Heath. 
De Vries, L. M. (1979). Up from the cellar. United States: Vanilla Press.

Denzin, N. (1989). Interpretive biography. Newbury Park, CA: Sage.

Deslarzes, P. (2004). Between social alienation and integration: the importance of narrated autobiography in the study of Italian migration in Basle in R. Franceschini and J. Miecznikowski (eds): Leben mit mehreren Sprachen/Vivre avec plusieurs langues [Living with multiple languages]. Bern: Peter Lang, pp. $227-49$.

Dorfman, A. (1999). Heading South, looking North: A bilingual journey. NY: Penguin Books.

Doty, P. (2003). The case study as a research method. Retrieved from http://www.getis.utexas.edu/ssoy/Usesusers/1391d1b.htm.

Duff, P. (2008). Case study research in applied linguistics. In the series Second language acquisition research: Theoretical and methodological issues. New York/London: Lawrence Erlbaum.

Dykman, E. (1999). Exploring second language acquisition and acculturation through autobiographical texts: A qualitative study of second language learners/authors. Unpublished doctoral dissertation.

Eire, C. (2003). Waiting for snow in Havana. Confessions of a Cuban Boy. Simon and Schuster Digital sales Inc.

Edwards, D. (1997). Discourse and cognition. London: Sage.

Ephron, N. (2010). I remember nothing. NY: Random House LLC. 
Engle, J., \& Engle, L. (1999). Program intervention in the process of cultural integration: The example of French practicum. Frontiers: The Interdisciplinary Journal of Study Abroad, 5: 39- 59.

Falk, R. \& N. A. Kanach (2000). Globalization and study abroad: An illusion of paradox. Frontiers: The Interdisciplinary Journal of Study Abroad 4, 155-168.

Fitzgerald, F. S. (2009). The Crack-Up. United States: New Directions.

Flowerdew, J., 2002. Genre in the classroom: a linguistic approach.

In: Johns, A.M. (Ed.), Genre in the Language Classroom. Mahwah, New Jersey: Lawrence Erlbaum Associates, pp. 91-102.

Frawley, W, and J P Lantolf. (1985). Second language discourse a Vygotskyan perspective. Applied Linguistics 6/1 18-43

Franceschini, R. (2003). Unfocussed Language Acquisition? The presentation of Linguistic situations in biographical narration, Forum: Qualitative Social Research [On-line journal], 4(3), Art. 19. Retrieved from http://www.qualitativeresearch.net/fqs-texte/3-03/3-03franceschini-e.htm.

Fraser, C. C. (2002). Study abroad: An attempt to measure the gains. German as a Foreign Language Journal, 1, 45- 65.

Freedman, A. (1994). "Do as I said": the relationship between teaching and learning new genres. In A. Freedman \& P. Medway (Eds.), Genre and the new rhetoric (pp. 191-210). London: Taylor \& Francies.

García Bermúdez, M. (1988). Mi familia durante la Guerra Civil Española. Unpublished Manuscript. 
Gee, J. (1991). A linguistic approach to narrative, Journal of Narrative and Life History 1/1: 15-39.

Goldman, E. (2006). Vision on fire: Emma Goldman on the Spanish revolution. United Kingdom: AK Press.

Gore, J. E. (2005). Dominant beliefs and alternative voices: Discourse, belief, and gender in American study abroad. New York: Routledge.

Goulah, J. (2007). Village voices, global visions: Digital video as a transformative foreign language learning tool. Foreign Language Annals, 40, 62- 78.

Grabe, W. (2002). Narrative and expository macro-genres. In A. M. Johns (Ed.), Genre in the classroom: Multiple perspectives (pp. 249- 267). Mahwah, $\mathrm{NJ}$ : Erlbaum.

Grabe, W. (2009). Reading in a second language: Moving from theory to practice. Cambridge: Cambridge University Press.

Gracian, B. (2010). The Art of worldly wisdom. Amazon Digital Services

Gregg, K. (1984). Krashens monitor and Occams razer. Applied Linguistics, 5, 79-100.

Gunnarsson, B. -L. (1997). The writing process from a sociolinguistic viewpoint. Written Communication, 14: 88-139.

Halliday, M. A. K. (1994). An introduction to functional grammar (2nd ed.). London: Edward Arnold. 
Halliday, M. A. K. (1999a). Grammar and the construction of educational knowledge. In R. Berry, B. Asker, K. Hyland \& M. Lam (Eds.), Language analysis, description and pedagogy (pp. 70- 87). Hong Kong: Language Centre, The Hong Kong University of Science \& Technology and Department of English, Lingnan University.

Halliday, M. A. K. (1999b). The notion of "context" in language education. In M. Ghadessy (Ed.), Text and context in functional linguistics (pp. 1-24). Amsterdam: Benjamins.

Halliday, M. A. K. (2002a). Spoken and written modes of meaning. In J. J. Webster (Ed.), On grammar (pp. 323-351). London: Continuum. Halliday, M. A. K. (2002b). Text semantics and clause grammar: How is a text like a clause? In J. J. Webster (Ed.), On grammar (pp. 219-260). London: Continuum.

Halliday, M., and Matthiessen, C., 2004. An introduction to functional grammar. 2nd ed. London: Arnold. P.121

Halliday, M. A. K., \& Matthiessen, C. M. I. M. (2006). Construing Experience through Meaning: A Language-Based Approach to Cognition. Open Linguistics Series, London: Continuum.

Hammond, J. \& Derewianka, B. (2001). Genre, Ch. 27 in The Cambridge Guide to Teaching English to speakers of Other Languages. Ed. by Carter, R. \& Nunan, D., Cambridge University Press.

Harklau, L. (2002). The role of writing in classroom second language acquisition. Journal of Second Language Writing, 11, 329-350 
Hasan, R. (1996b). Literacy, everyday talk and society.

In R. Hasan \& G. Williams (Eds.), Literacy in society (pp. 377-424). London: Longman.

Hasan, R. (1996c). What's going on: A dynamic view of context in language.

In C. Cloran, D. Butt, \& G. Williams (Eds.), Ways of saying:

Ways of meaning. Selected papers of Ruqaiya Hasan (pp. 37-50). London: Cassell.

Hassan, T. E. (2015) A classroom revolution: Reflections on Harkness learning and teaching. Exeter: Phillips Exeter Academy Press.

Heinz, B. (2001). "Fish in the river": Experiences of bicultural bilingual speakers, Multilingua 20/1: 85-108.

Herbst, J. (1999). The starched blue sky of Spain and other memoirs. Lebanon: Northeastern University Press.

Heskel, J. \& Dyer, D. (2008) After the Harkness Gift: A History of Phillips Exeter Academy since 1930. Phillips Exeter.

Hinkel, E. (2002). Second language writers' text: Linguistic and rhetorical features. Mahwah, NJ: Erlbaum.

Hirvela, A. (2004). Connecting reading and writing in second language writing instruction. Ann Arbor, Ml: The University of Michigan Press.

Hoffman, E. (1989) Lost in translation: A life in a new language. NY: Penguin Books.

Hokenson, J. (1995). Intercultural autobiography, a/b: Auto/Biography Studies 10/1: 92-113. 
Holmes, J. (1998). Narrative structure: Some contrasts between Maori and Pakeha story-telling, Multilingua 17/1: 25-57.

Hymes, D. (1982). Narrative form as a "grammar" of experience: Native American and a glimpse of English,' Journal of Education 162: 121-42.

Huang, J., \& Mohan, B. (2009). A functional approach to assessing student discourse and the integration of language, content, and culture in an elementary Chinese program. Linguistics and Education, 20, 22- 38.

Huebner, T. (1995). The effects of overseas language programs:

Report on a case study of an intensive Japanese course.

In B. Freed (Ed.), Second language acquisition in a study abroad context (pp. 171-193). Philadelphia: Benjamins.

Huttner, Julia, Smit, Ute, Mehlmauer-Larcher, Barbara. (2009).

ESP teacher education at the interface of theory and practice: Introducing a model of mediated corpus-based genre analysis. Amsterdam: Elsevier Ltd.

Hunt, D. (1990). The Dolphin Reader. Boston: Houghton Mifflin.

Hyland, K. (2003a). Genre-based pedagogies: A social response. Journal of Second Language Writing, 12, 17- 29.

Hyland, K. (2003b). Second language writing. Cambridge, UK: Cambridge University Press.

Hyland, K. (2004). Genre and second language writing. Ann Arbor, MI: The University of Michigan Press.

Hyon, S. (2001). Long-term effects of genre-based instruction: a follow-up study of an EAP reading courses. English for Specific Purposes, 20, 417-438. 
Hyon, S. (1996). Genre in three traditions: Implications for ESL.

TESOL Quarterly 30/4: 693-722.

Ivens, Jorens. (1937). The Spanish Earth. Documentary.

Jackson, J. (2006). Ethnographic pedagogy and evaluation in short-term study

abroad. In M. Byram \& A. Fong (Eds.), Living and studying abroad: Research and practice (pp. 134- 156). Clevedon, UK: Multilingual Matters.

James, D. (1998). Reply to Forum responses: "Bypassing the traditional leadership: Who's minding the store?" ADFL Bulletin, 29(3), 64-68.

Januleviciene, V. and G. Kavaliauskiene. (2002). Promoting the Fifth Skill in Teaching ESP in English for Specific Purposes. World 2/1: available at http://www.esp-world.info/Articles.

Javier, R., F. Barroso and M. Muñoz. (1993).

Autobiographical memory in bilinguals, Journal of Psycholinguistic Research 22/3: 319-38.

Johns, A. M. (1995a). Genre and pedagogical purposes. Journal of Second Language Writing, 4, 181-190.

Johns, A. M. (2002). Genre in the classroom: Multiple perspectives. Mahwah, NJ: Lawrence Erlbaum.

Johns, A. M. (2003). Genre and ESL/EFL composition instruction. In B. Kroll (Ed.), Exploring the dynamics of second language writing (pp. 195-217). Cambridge, UK: Cambridge University Press.

Jordan, Riverda H. (1921) Retention of Foreign Language in the Home. Journal of Educational Research 3(I):35-42. 
Josselson R. and Lieblich A. (eds) (1993). The Narrative Study of Lives'.

Volume 3. Interpreting Experience. Thousand Oaks, CA: Sage, pp. 173-204.

Judd, E. L. (1999). Some issues in the teaching of pragmatic competence in E. Hinkel (ed.): Culture in Second Language Teaching and Learning. New York: Cambridge University Press.

Jurasek, R., Lamson, H., \& O'Maley, P. (1995). Ethnographic learning in study abroad. Study abroad: Research on learning language and culture in context. Proceedings of RP-ALLA '95, Columbus: Ohio State University National Foreign Language Resource Center, 62- 84.

Kaplan, A. (2009). French lessons: A memoir. University of Chicago Press.

Kaplan, R. (1987). Cultural thought patterns revisited.

In U. Connor \& R. Kaplan (Eds.), Writing across languages:

Analysis of L2 texts (pp. 9-21). Reading, MA: Addison-Wesley.

Karr, M. (2015). The art of Memoir. New York: Harper Collins Publishers.

Kern, R. (2000). Literacy and Language Teaching. New York:

Oxford University Press.

Kern, R. G., \& Schultz, J. M. (1992). The effects of composition instruction on intermediate level French students' writing performance: Some preliminary findings. Modern Language Journal, 76, 1- 12.

Kern, R. \& Schultz, J.M. (2005). Beyond orality: Investigating literacy and the literary in Second and Foreign Language instruction. The Modern Language Journal, Vol.89(3), pp.381-392. 
Kiely, R., \& Nielson, D. (2003). International service learning:

The importance of partnerships. Community College Journal, 73, 39- 41.

King, H. (2006). Parched. Penguin Group (USA) LLC.

Kinginger, C. (2004). Bilingualism and emotion in the autobiographical works of Nancy Huston, Journal of Multilingual and Multicultural Development 25/2-3: $159-78$.

Kinginger, C. (2004c). Communicative foreign language teaching through telecollaboration. In O. St. John, K. van Esch, \& E. Schalkwijk (Eds.), New insights into foreign language learning and teaching (pp. 101-113). Frankfurt: Peter Lang.

Kinginger, C. (2009) American students abroad: Negotiation of difference? Lang. Teach. (2010), 43:2, 216-227, Cambridge University Press.

Kingston H. M. (2010). The woman warrior: Memoirs of a girlhood among ghosts. New York: Random House LLC.

Koven, M. (1998). Two languages in the self/the self in two languages: French-Portuguese bilinguals' verbal enactments and experiences of self in narrative discourse, Ethos 26/4: 410-55.

Koven, M. (2001). Comparing bilinguals' quoted performances of self and others in tellings of the same experience in two languages, Language in Society 30: 513-58.

Koven, M. (2002). An analysis of speaker role inhabitance in narratives of personal experience, Journal of Pragmatics 34: 167-217. 
Koven, M. (2004). Getting "emotional" in two languages: Bilinguals' verbal performance of affect in narratives of personal experience, Text 24/4: 471-515.

Kramsch, C. and W. E. Lam. (1999). Textual identities: The importance of being non-native in G. Braine (ed.): Non-native Educators in English Language Teaching. Mahwah, NJ: Lawrence Erlbaum, pp. 57-72.

Kramsch, C. (2000). Linguistic identities at the boundaries. Paper presented at the AAAL Annual Convention, Vancouver, Canada, 12 March.

Kramsch, C. (2006a). From communicative competence to symbolic competence. Modern Language Journal 90(2): 249-252

Kramsch, C. (2009). The multilingual subject. Oxford University Press.

Krashen, S. D. (1982). Principles and practices in second language acquisition. Oxford: Pegamon Press.

Kress, G. (2000). Multimodality. In B. Cope \& M. Kalantzis (Eds.), Multiliteracies: Literacy learning and the design of social futures (pp. 182-202). London: Routledge.

Lafford, B., \& Collentine, J. (2006). The effects of study abroad and classroom contexts on the acquisition of Spanish and a second language. In R. Salaberry \& B. Lafford (Eds.), The art of teaching Spanish: Second language acquisition from research to praxis (pp. 103-126). Washington, DC: Georgetown University Press.

Lahiri, J. (2016). In other words. New York: Random House LLC. 
Lambert D. R. (1985). Foreign Language Instruction: A National Agenda.

Foreign Language Annals. Volume 18, Issue5.

American Council on the Teaching of Foreign Languages.

Lamott, A. (2007). Bird by bird: some instructions on writing and life.

New York: Random house LLC

Lantolf, J. P. (2004). Sociocultural theory and second and foreign

language learning: An overview of sociocultural theory.

In K. van Esch \& O. St. John (Eds.), New insights into foreign

language learning and teaching (pp. 13-34).

Frankfurt: Peter Lang Verlag.

Larsen-Freeman, D., \& Cameron, L. (2008a). Complex systems and applied linguistics. Oxford: Oxford University Press.

Lee, L. (2011). As I walked out one midsummer morning.

United Kingdom: David R. Godine.

Lee, L. (2014). A moment of war: A Memoir. United States: Open Road Media.

Leki, I., \& Carson, J. (1997). "Completely different worlds": EAP and the writing experiences of ESL students in university courses. TESOL Quarterly, 31, 39- 69.

Leki, I. (1995). Good writing: I know it when I see it. In D. Belcher \& G. Braine (Eds.), Academic writing in a second language: Essays on research and pedagogy (pp. 23-46). Norwood, NJ: Ablex. 
Leppanen, S. and P. Kalaja. (2002). Autobiographies as constructions of EFL learner identities and experiences in E. Karkkainen, J. Haines, and T. Lauttamus (eds): Studia Linguistica et Litteraria Septentrionalia. Studies Presented to Heikki Nyyssonen. Oulu: Oulu University Press, pp. 189-203.

Levin, D. M. (2001). Language learners' sociocultural interaction in a study abroad context (Doctoral dissertation, Indiana University, 2001). Dissertation Abstracts International A, 62, 498.

Lewis, C. S. 1966. Surprised by joy: The shape of my early life. New York: Houghton Mifflin Harcourt.

Lightbown, P. M. and N. Spada. (1999). How Languages are Learned, 2nd edn. New York: Oxford University Press. Lightbown, P. M., \& Pienemann, M. (1993). Comments on Stephen D. Krashens "Teaching issues: Formal grammar instruction". TESOL Quarterly, 27, 717-722.

Linde, C. (1993). Life stories: The creation of coherence. New York: Oxford University Press.

Long M. \& Crookes, G. (1993) Tasks in a pedagogical context: integrating theory and practice. Clevedon, UK: Multilingual Matters.

Lomas, T. (2017). The value of ambivalent emotions: A cross-cultural lexical analysis. Qualitative Research in Psychology. Retrieved from: https://www.researchgate.net/publication/320918554_The_value_of_ambivalent_ emotions_a_cross-cultural_lexical_analysis 
Lopate, P. (1995). The art of the personal essay: An anthology from the classical era to the present. United Kingdom: Anchor Books.

Lopate, P. (2013). To Show and to Tell: The Craft of Literary Nonfiction. Simon and Schuster Digital Sales Inc.

Lvovich, N. (2013). The Multilingual Self: An Inquiry into Language Learning. England: Routledge.

Macken-Horarik, M. (1996). Literacy and learning across the curriculum: Towards a model of register for secondary school teachers. In R. Hasan \& G. Williams (Eds.), Literacy in society (pp. 232- 278). London: Longman.

Mackenzie N. M. \& Daffern T. (2020), Ch. 7.

Teaching writing: Effective approaches for the middle years. United Kingdom: Taylor \& Francis.

Malinowski, B. (1935). Coral gardens and their magic (Vol. 2). London: Allen \& Unwin.

Manchon, M R and Haan, P. (2008). Writing in Foreign language contexts; research insights, Journal of Second Language Writing, Volume 17, Issue 1, 1-6.

Marian, V. and M. Kaushanskaya. (2004). Self Construal and emotion in bicultural bilinguals, Journal of Memory and Language 51: 190-201.

Marquez, G. G. (2014). Living to Tell the Tell. New York: Random House LLC.

Martin, J. R. (1984). Language, Register, and Genre. in F. Christie (ed). Children Writing: Reader. Geelong, Australia: Deakin University Press. 
Martin, J. R. and R. Rothery. (1981). The ontogenesis of written genres.

Working Papers in Linguistics No. 2. Department of Linguistics, University of Sydney.

Martin, J. R. (1997). Analyzing genre: Functional parameters.

In F. Christie \& J. R. Martin (Eds.), Genre and institutions: Social processes in the workplace and school (pp. 3-39). London: Continuum.

Martin, J. R. (2002a). A universe of meaning-How many practices?

In A. M. Johns (Ed.), Genre in the classroom:

Multiple perspectives (pp. 269-278). Mahwah, NJ: Erlbaum.

Martin, J. R. (2009). Genre and language learning: A social semiotic perspective. Linguistics and Education, 20, 10- 21.

Martinez Lirola, M. (2006). The importance of teaching Systemic Functional Linguistics and text linguistics to improve writing in bilingual education programs in the USA. Porta Linguarum 5, pp. 139-150.

Matsuda and De Pew, (2002), Early second language writing: An introduction. Journal of Second Language Writing, 11, pp. 261-268

Matsuda, P. K., Canagarajah, A. S., Harklau, L., Hyland, K., \& Warschauer, M. (2003). Changing currents in second language writing research: A colloquium. Journal of Second Language Writing, 12, 151-179.

Matthiessen, C. M. I. M. (1993). Diversity in a unified theory of register analysis.

In M. Ghadessy (Ed.), Register analysis: Theory and practice (pp. 221- 292). London: Pinter. 
Matthiessen, C. M. I. M. (2006). Educating for advanced foreign language capacities: Exploring the meaning-making resources of languages systemicfunctionally. In H. Byrnes (Ed.), Advanced language learning: The contribution of Halliday and Vygotsky (pp. 31-57). London: Continuum.

Matthiessen, C. M. I. M. (2009). Meaning in the making: Meaning potential emerging from acts of meaning. Language Learning, 59 (Suppl. 1), 206- 229.

Matthiessen, C. M. I. M., Teruya, K., \& Wu, C. (2008). Multilingual studies as multi-dimensional space. In J. J. Webster (Ed.), Meaning in context: Strategies for implementing intelligent applications of language studies (pp. 146-220). London: Continuum.

McCabe, A. and L. Bliss. (2003). Patterns of narrative discourse: A multicultural, life span approach. Boston, MA: Allyn and Bacon.

McEnery, T., Wilson, A., (1996). Corpus linguistics.

Edinburgh University Press, Edinburgh.

McLaughlin, B. (1987). Theories of second-language learning. London: Edward Arnold.

Merton, T. (1998). The seven story mountain. Mariner Books, Boston: Houghton Mifflin Harcourt.

Michaels, S. (1981). "Sharing time": Children's narrative styles and differential access to literacy, Language in Society 10: 423-42.

MLA (Modern Language Association) (2007). Foreign Languages and Higher Education, New Structures for a Changed World. 
MLA (Modern Language Association) (2008). Language, literature, and liberal education.

Mura, D. Turning Japanese: Memoirs of a Sansei. (2007). Grove press.

Murphy-Lejeune, E. (2002). Student mobility and narrative in Europe:

The new strangers. London: Routledge.

Natlinger, J R, and J S DeCarrico. (1992). Lexical phrases in language teaching. Oxford University Press.

Nekvapil, J. (2003). Language biographies and the analysis of language situations: On the life of the German community in the Czech Republic, International Journal of the Sociology of Language 162: 63-83.

Neruda, P. (2011). Confieso que he vivido. Editorial Planeta S.A.U.

Newby, D., (2003). The interface between theory and practice. In: Newby, D. (Ed.), Mediating Between Theory and Practice in the Context of Different Learning Cultures and Languages. Council of Europe Publishing, Strasbourg, pp. $15-22$.

Norton, B. (2000). Identity and language learning. New York: Pearson Education Limited.

Norris, J. M., \& Ortega, L. (2003). Defining and measuring SLA. In C. Doughty \& M. H. Long (Eds.), Handbook of second language acquisition (pp. 716- 761). London: Blackwell.

Norris, M. J., (2006), The why (and how) of assessing student learning outcomes in college foreign language programs, The Modern Language Journal 90: $576-582$. 
Norris, J. M. (2006a). Assessing advanced foreign language learning and learners: From measurement constructs to educational uses. In H. Byrnes, H. Weger-Guntharp, \& K. A. Sprang (Eds.), Educating for advanced foreign language capacities: Constructs, curriculum, instruction, assessment (pp. 167-187). Washington, DC: Georgetown University Press.

Norris, J. M. (2008). Validity evaluation in language assessment. Frankfurt: Peter Lang.

Norris, J. M. (2009). Task-based teaching and testing.

In M. Long \& C. Doughty (Eds.), Handbook of language teaching (pp. 578- 594). Cambridge: Blackwell.

Omaggio Hadley, A., (1986). Teaching language in context. Boston: Heinle \& Heinle.

On Harkness, retrieved from: $\underline{\text { http://www.exeter.edu/admissions/109 } 1220 \text { 11688.aspx }}$ Ogulnick, K. (1998). Onna rashiku (Like a Woman): The Diary of a language learner in Japan. Albany, NY: SUNY Press.

Ogulnick, K. (1999). Introspection as a method of raising critical language awareness, Journal of Humanistic Education and Development 37:145-159.

Orr, L. (2009) Letters from Barcelona: An American woman in revolution and civil war. United Kingdom: Palgrave Macmillan UK.

Ortega, L. (2000). Understanding syntactic complexity: The measurement of change in the syntax of instructed L2 Spanish learners. Unpublished doctoral dissertation, University of Hawaii at Manoa, Honolulu. 
Ortega, L. (2003). Syntactic complexity measures and their relationship to L2 proficiency: A research synthesis of college-level L2 writing'. Applied Linguistics, 24, 492-518.

Ortega L. \& H. Byrnes (Eds.). (2008a). The longitudinal study of advanced L2 capacities. New York: Routledge.

Ortega L. \& H. Byrnes, (2008b). Theorizing advancedness: Setting up the longitudinal research agenda. In L. Ortega \& H. Byrnes (Eds.), The longitudinal study of advanced L2 capacities (pp. 281-299). New York: Routledge.

Paltridge, B. (2001). Genre and the language learning classroom. Ann Arbor, Ml: The University of Michigan Press.

Poetter T.(1997). Voices of Inquiry in Teacher Education. Lawrence Erlbaum Associates, Mahwah, NJ.

Paige, R. M., Cohen, A. D., Kappler, B., Chi, J., \& Lassegard, J. P. (2002). Maximizing study abroad: A student's guide to strategies for language and culture learning and use. Minneapolis: University of Minnesota Center for Advanced Research on Language Acquisition.

Paige, R. M., Cohen, A. D., \& Shively, R. L. (2004). Assessing the impact of a strategies-based curriculum on language and culture learning abroad. Frontiers: The Interdisciplinary Journal of Study Abroad, 10, 253- 276.

Painter, C. (1996). The development of language as a resource for thinking: A linguistic view of learning. In R. Hasan \& G. Williams (Eds.), Literacy in society (pp. 50- 85). London: Longman. 
Pang, T. (2002). Textual analysis and contextual awareness building:

a comparison of two approaches to teaching genre. In A. M. Johns (Ed.), Genre in the classroom: Multiple perspectives (pp. 145-161). Mahwah, NJ: Lawrence Erlbaum.

Paribakht, T., \& Wesche, M. (1996). Vocabulary enhancement activities and reading for meaning in second language vocabulary acquisition. In J. Coady \& T. Huckin (Eds.), Second Language Vocabulary Acquisition: A Rationale for Pedagogy (Cambridge Applied Linguistics, pp. 174-200. Cambridge: Cambridge University Press.

Parodi, G. (2010). Written discourse genres: Towards an integral conception from a sociocognitive perspective. In G. Parodi (Ed.), Academic and professional discourse genres in Spanish (pp. 17-35). Amsterdam: Benjamins.

Patton, M. Q. (1997). Utilization-focused evaluation: The new century text.

Thousand Oaks, CA: Sage. (eds) Second Language Vocabulary Acquisition, Cambridge University Press.

Pavlenko, A. (1998). Second language learning by adults: Testimonies of bilingual writers, Issues in Applied Linguistics 9/1: 3-19.

Pavlenko, A., \& Lantolf, J. P. (2000). Second language learning as participation and the (re)construction of selves. In J. P. Lantolf (Ed.), Sociocultural theory and second language learning (pp. 155-177). New York: Oxford University Press.

Pavlenko, A. (2001a). Language learning memoirs as a gendered genre, Applied Linguistics 22/2: 213-40. 
Pavlenko, A. (2001b). In the world of tradition, I was unimagined: Negotiation of identities in cross-cultural autobiographies, The International Journal of Bilingualism 5/3: 317-44.

Pavlenko, A. (2004). The Making of an American: Negotiation of identities at the turn of the 20th century' in A. Pavlenko and A. Blackledge (eds): Negotiation of Identities in Multilingual Contexts. Clevedon, UK: Multilingual Matters, pp. 334-67.

Pavlenko, A. (2005). Emotions and Multilingualism. Cambridge, UK: Cambridge University Press.

Pavlenko, A. (2008). Narrative analysis in the study of bi- and multilingualism' p.311 In M. Moyer and Li Wei (eds): The Blackwell Guide to Research Methods in Bilingualism. Oxford: Blackwell.

Philips, Susan U. (1998) Language Ideologies in Institutions of Power: A Commentary. In Language Ideologies: Practice and Theory. Bambi B. Schieffelin, Kathryn A. Woolard, and Paul V. Kroskrity, eds. Pp. 211-225. New York: Oxford.

Pinker, S. (2010). The language instinct: How the mind creates language. (P.S.). HarperCollins Publishers.

Poetter T.(1997). Voices of inquiry in teacher education. Lawrence Erlbaum Associates, Mahwah, NJ.

Polanyi, L. (1995). Language learning and living abroad: Stories from the field. in B. Freed (ed.): Second Language Acquisition in a Study Abroad Context. Amsterdam/Philadelphia: John Benjamins, pp. 271-91. 
Ragan, P. (1989). Applying functional grammar to teaching the writing of ESL. Word $40(1-2)$ 117-127.

Ramanathan, V., \& Kaplan, R. B. (2000). Genres, authors, discourse communities: theory and application for (L1 and) L2 writing instructors. Journal of Second language writing, 9, 171-191.

Raschio, R. A. (2001). Integrative activities for the study-abroad setting. Hispania, 84, 534-541

Reid, J. (1990). Responding to different topic types a quantitative analysis from a contrastive rhetoric perspective in B Kroll (ed) Second Language Writing, Cambridge University Press.

Respecting the Pupil: Essays on Teaching Able Students (1981) by members of the faculty of PEA. Donald B. Cole and Robert H. Cornell, editors. Exeter: The Phillips Exeter academy Press.

Ricento, T \& Burnaby, B (1998). Language and politics in the United States and Canada: Myths and realities. (Eds.). Mahwah, NJ: Erlbaum. $\operatorname{Pp} x v+357$.

Richards, J. C., \& Rogers, T. S. (2001). Approaches and methods in language teaching. New York: Cambridge University Press.

Ricoeur, P. (1990). Soi-me^me comme un autre [Self as the other]. Paris: Editions du Seuil.

Riessman, C. (1993). Narrative Analysis. Newbury Park, CA: Sage. 
Rintell, E. (1990). That's incredible: Stories of emotion told by second language learners and native speakers in R. Scarcella, E. Andersen, and S. Krashen (eds): Developing Communicative Competence in a Second Language. Boston, MA: Heinle \& Heinle, pp. 75-94.

Roberts, C., Byram, M., Barro, A., Jordan, S., \& Street, B. (2001).

Language learners as ethnographers. Clevedon, UK: Multilingual Matters.

Rothery, J. (1996). Making changes: Developing an educational linguistics.

In R. Hasan \& G. Williams (Eds.), Literacy in society (pp. 86-123). London: Longman.

Rothery, J., \& Stenglin, M. (1997). Entertaining and instructing:

Exploring experience through story. In F. Christie \& J. R. Martin (Eds.), Genre and institutions: Social processes in the workplace and school (pp. 231-263). London: Cassell.

Rodriguez, R. (2004). Hunger of memory: The education of Richard Rodriguez. Random House LLC.

Rosa, M. (1997). Personal narratives of learning English as a second language as experienced by four college students in Puerto Rico. Unpublished doctoral dissertation, School of Education, New York University.

Rosch, E. (1975). Cognitive representations of semantic categories. Journal of Experimental Psychology' (General) 104: 192-233. 
Rothery, J., \& Stenglin, M. (1997). Entertaining and instructing: Exploring experience through story. In F. Christie \& J. R. Martin (Eds.), Genre and institutions: Social processes in the workplace and school (pp. 231-263). London: Cassell.

Rumelhart, D. (1975). Notes on a schema for stories in D. Bobrow and A. Collins (eds): Representation and Understanding: Studies in Cognitive Science. New York: Academic Press.

Ryshina-Pankova, M. (2006). Creating textual worlds in advanced learner writing: The role of complex theme. In H. Byrnes (Ed.), Advanced language learning: The contribution of Halliday and Vygotsky (pp. 164-183). London: Continuum.

Ryshina-Pankova, M. (2010). Toward mastering the discourses of reasoning: Use of grammatical metaphor at advanced levels of foreign language acquisition. Modern Language Journal, 94, 181-197.

Ryshina-Pankova, M \& Byrnes, H. (2013). Writing as learning to know: Tracing knowledge construction in L2 German compositions. Journal of Second Language Writing 22, 179-197.

Santana, J. (1999). Americanization: A Dominican immigrant's autobiographical study of cultural and linguistic learning. Unpublished doctoral dissertation, School of Education, New York University. 
Segers E. \& van den Broek, P (2017) Developmental Perspectives in Written Language and Literacy: In Honor of Ludo Verhoeven. Netherlands: John Benjamins Publishing Company.

Schank, R. and R. Abelson. (1977). Scripts, plans, goals, and understanding: An inquiry into human knowledge structures. Hillsdale, NJ: Lawrence Erlbaum.

Schulz, R. A. (2006). Reevaluating communicative competence as a major goal in postsecondary language requirement courses. Modern Language Journal, 90, 252- 255.

Schiffman, H. F. (1996). Linguistic culture and language policy. New York: Routledge.

Schneider, A. (2001). A university plans to promote languages by killing its L anguages department. Chronicle of Higher Education, March 9.

Schneider, P. (2013). How the lights get in: Writing as a spiritual practice. Oxford University Press, Amazon Digital Services LLC.

Schwarzer, D. and C. Luke. (2001). Inquiry cycles in a whole language foreign language class: Some theoretical and practical insights, retrieved from: http://studentorgs.utexas.edu/flesa/tpfle/contents5.doc.

Schumann, F. (1980). Diary of a language learner: A further analysis in R. Scarcella and S. Krashen (eds): Research in Second Language Acquisition: Selected Papers of the Los Angeles Second Language Acquisition Research Forum. Rowley, MA: Newbury House, pp. 51-7. 
Schumann, J. (1997). The Neurobiology of affect in language.

Boston: Blackwell.

Silva, T., \& Leki, I. (2004). Family matters: The influence of applied linguistics and composition studies on second language writing studies-Past, present, and future. Modern Language Journal, 88, 1-13.

Silva, T and Cimasko, T. (2008). Selected bibliography of recent scholarship in second language writing. Purdue University, United States, Journal of Second Language Writing 17, 208-215.

Sinclair, J.M., (1997). Corpus evidence in language description. In: Wichmann, A. , Fligelstone, S., McEnery, T., Knowles, G. (Eds.), Teaching and Language Corpora. Longman, London/New York, pp. 27-39.

Skehan, P. (1998). Task-based instruction. Annual Review of Applied Linguistics, 18, 268- 286.

Slobin, D. (1996). From "thought and language" to "thinking for speaking." In J. Gumperz \& S. Levinson (eds.), Rethinking linguistic relativity (70-96). Cambridge: Cambridge University Press.

Sprang, K. A. (2003). Vocabulary acquisition and advanced learners: The role of grammaticization and conceptual organization in the acquisition of German verbs with inseparable prefixes. Unpublished doctoral dissertation, Georgetown University, Washington, DC. Standards for foreign language learning: Preparing for the 21st century. (1996). National Standards in Foreign Language Education Project, Yonkers, NY. 
Starinov, Anna K. (2001). Behind fascist lines: A firsthand account of guerrilla warfare during the Spanish revolution. Ballantyne Press: New York.

Stenhouse, L. (1975). An Introduction to curriculum research and development, Heinemann, London.

Strauss, A. and J. Corbin. (1990). Basics of qualitative research: Grounded theory procedures and techniques. Newbury Park, CA: Sage.

Strayed, C. (2012). Wild: From lost on the Pacific Crest Trail. Random House LLC.

Swaffar, J. K. (1988). Readers, texts, and second languages:

The interactive processes. Modern Language Journal, 72, 123-149

Swaffar, J. (1999). The case for foreign languages as a discipline. ADFL Bulletin, 30(3), 6- 12.

Swaffar, J. (2006). Terminology and its discontents:

Some caveats about communicative competence. Modern Language Journal, 90, 246- 249.

Swaffar and Arens. (2005). Remapping the foreign language curriculum: An approach through multiple literacies. New York: MLA.

Swain, M. (2006). Languaging, agency and collaboration in advanced second language proficiency. In H. Byrnes (Ed.), Advanced language learning: The contribution of Halliday and Vygotsky (pp. 95-108). London: Continuum. 
Swales, J. M., H Jacobsen, C Kejser, L Koch, J Lynch, and L Molbaek. (2000). A new link in a chain of Genres? Hermes 25: 133-41.

Swales, J. M., \& Lubes, M. A. (2002). Genre analysis and the advanced second language writer. In E. Barton \& G. Stygall (Eds.), Discourse studies in composition (pp. 135-154). Cresskill, NJ: Hampton Press.

Talburt, S., \& Stewart, M. A. (1999). What's the subject of study abroad?

Race, gender and "living culture." Modern Language Journal, 83, 163- 175. Boston.

Tannen, D. (1982). Spoken and written narrative in English and Greek in D. Tannen (ed.): Coherence in Spoken and Written Discourse. Norwood, NJ: Ablex, pp. 21-41.

The Lawrenceville School. (2015-2016) Perspectives. Harkness Learning and Teaching. Retrieved from ISSUU.

The New London Group, (1996) A Pedagogy of multiliteracies: Designing social futures. Harvard Educational Review, Volume 66, 1.

Todorov, T. (1987). Structural analysis of narrative in R. Davis (ed.): Contemporary Literary Criticism: Modernism Through Post-structuralism. London: Longman, pp. 323-30.

Toolan, M. (2001). Narrative: A critical linguistic introduction. 2nd ed. Routledge. 
Treichel, B. (2004). Suffering from one's own multilingualism:

Biographical processes of suffering and their linguistic expression in narrative interviews with Welsh speakers of Welsh and English' in R. Franceschini and J. Miecznikowski (eds): Leben mit mehreren Sprachen/Vivre avec plusieurs langues [Living with multiple languages]. Bern: Peter Lang, pp. 47-74.

Tribble, C. (2001). Small corpora and teaching writing. Towards a corpus-informed pedagogy of writing. In: Mohsen, G., Henry, A., Roseberry, R. (Eds.), Small Corpus Studies and ELT. John Benjamins, Amsterdam/Philadelphia, pp. 381-408.

Tse, L. (2000a). Student perceptions of foreign language study:

A qualitative analysis of foreign language autobiographies, Modern Language Journal 84/1: 69-84.

Tse, L. (2000b). The effects of ethnic identity formation on bilingual maintenance and development: An analysis of Asian American narratives, International Journal of Bilingual Education and Bilingualism 3/3: 185-200.

Tucker, G. R. Padilla, A. M., Lindholm, K. J., Chen, A., Durán, R., Hakuta, K., Lambert, W., (1991). The English-only movement: Myths, reality, and implications for psychology. American Psychologist, 46(2), 120-130.

Twain, M. (2014). Autobiography of Mark Twain (Volume 1\& 2) (Original Classics Edition). Original Classics.

Valdés, G., Haro, P., \& Echevarriarza, M. P. (1992). The development of writing abilities in a foreign language: Contributions toward a general theory of L2 writing. Modern Language Journal, 76, 333- 352 
Valdes, Gonzalez S., Garcia Lopez, D, Marquez, P (2003) Language Ideology: The Case of Spanish in Departments of Foreign Languages. Anthropology \& Education Quarterly 34(I):3-26. American Anthropological Association.

Valdés, G. (2004). The teaching of academic language to minority second language learners. In A. F. Ball \& S. W. Freedman (Eds.), Bakhtinian perspectives on language, literacy, and learning (pp. 66-98). New York: Cambridge University Press.

Verspoor, M., Lowie, W., \& van Dijk, M. (2008). Variability in second language development from a dynamic systems perspective. Modern Language Journal, 92, 214- 231.

Vitanova, G. (2005). Authoring the self in a nonnative language:

A dialogic approach to agency and subjectivity in J. K. Hall, G. Vitanova, and L. Marchenkova (eds): Dialogue with Bakhtin on Second and Foreign Language Learning: New Perspectives. Mahwah, NJ: Lawrence Erlbaum, pp. 149-69.

Von Stutterheim, C., \& Carroll, M. (2006). The impact of grammatical temporal categories on ultimate attainment in L2 learning. In H. Byrnes, $\mathrm{H}$. Weger-Guntharp, \& K. A. Sprang (Eds.), Educating for advanced foreign language capacities: Constructs, curriculum, instruction, assessment (pp. 40- 53). Washington, DC: Georgetown University Press.

Vygotsky, L. S. (1978). Mind and society: The development of higher mental processes. Cambridge, MA: Harvard University Press. 
Wellmon, C. (2008). Languages, cultural studies, and the futures of foreign language education. Modern Language Journal, 92, 292- 295.

Wells, G. (1998). Using L1 to master L2: A response to Antón and DiCamilla's cognitive functions of L1 collaborative interaction in the L2 classroom, The Canadian Modern Language Review 54/3, 343-52

Wenden, A. (2002). Learner development in language learning. Applied Linguistics, 23, 32-55.

White, L. J., Maylath, B., Adams, A., \& Couzijn, M. (2000). Language awareness: A history and implementations. Amsterdam: Amsterdam University Press.

Widdowson, H., (1983). Learning purpose and language use. Oxford University Press, Oxford.

Widdowson, H., (1990). Aspects of language teaching. Oxford University Press, Oxford.

Wiggins, G., \& McTighe, J. (2005). Understanding by design. New York: Prentice Hall.

Wiggins, G. (1998). Educative assessment: Designing assessments to inform and improve student performance. San Francisco: Jossey-Bass.

Wilkinson, S. (2002). The omnipresent classroom during summer study abroad: American students in conversation with their French hosts. Modern Language Journal, 86, 157- 173.

Witte, S. (1992). Context, text and intertext: Towards a constructionist semiotic of writing. Written Communication, 9: 237-308.

Wittgenstein, L. (1958). Philosophical Investigations. Oxford: Basil Blackwell. 
Woolsey, G. (1998). Malaga burning: an American woman's eyewitness account of the Spanish Civil War. United States: Pythia Press.

Wortham, S. (2001). Narratives in Action: A Strategy for Research and Analysis. New York: Teachers' College Press.

Yagoda, B. (2009). Memoir: A History. Penguin Group (USA) LLC.

Yelenevskaya, M. and L. Fialkova. (2003). From "muteness" to "eloquence": Immigrants narratives about languages, Language Awareness 12/1: 30-48. 